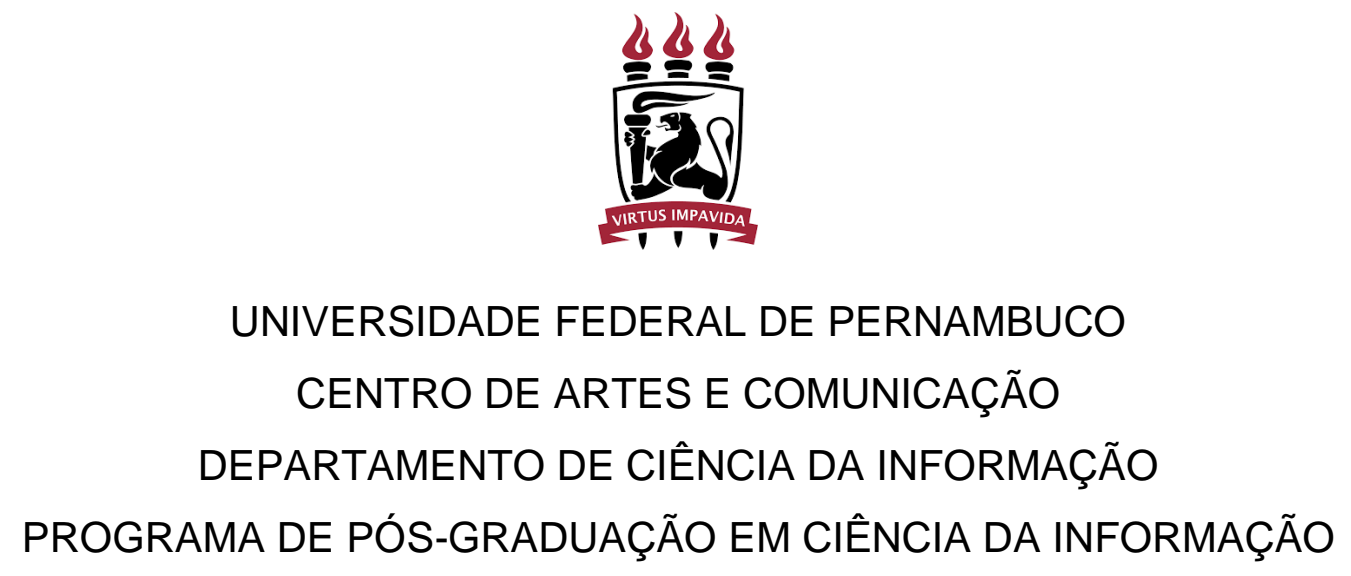

MÔNICA REJANE DE LIRA CLEMENTE TORRES

GESTÃO DA INFORMAÇÃO APLICADA AOS PROCESSOS

DE TRABALHO DO IBAMA

Recife

2019 


\title{
GESTÃO DA INFORMAÇÃO APLICADA AOS PROCESSOS DE TRABALHO DO IBAMA
}

\begin{abstract}
Dissertação apresentada ao Programa de Pós-Graduação em Ciência da Informação da Universidade Federal de Pernambuco, como requisito parcial para a obtenção do título de Mestre em Ciência da Informação.

Área de concentração: Informação, Memória e Tecnologia
\end{abstract}

Orientadora: Prof. ${ }^{a}$ Dr. ${ }^{\text {a }}$ Nadi Helena Presser

Coordenadora: Prof. $\stackrel{\text { a }}{\text { Dr. }}$ - Sandra de Albuquerque Siebra 
T693g Torres, Mônica Rejane de Lira Clemente

Gestão da informação aplicada aos processos de trabalho do Ibama / Mônica Rejane de Lira Clemente Torres. - Recife, 2019.

159f.: il.

Orientadora: Nadi Helena Presser.

Dissertação (Mestrado) - Universidade Federal de Pernambuco. Centro de Artes e Comunicação. Programa de Pós-Graduação em Ciência da Informação, 2019.

Inclui referências, anexo e apêndices.

1. Gestão da Informação. 2. Comportamento Informacional. 3. Ibama. 4. Contexto Social. I. Presser, Nadi Helena (Orientadora). II. Título. 


\title{
GESTÃO DA INFORMAÇÃO APLICADA AOS PROCESSOS DE TRABALHO DO IBAMA
}

\begin{abstract}
Dissertação apresentada ao Programa de Pós-Graduação em Ciência da Informação da Universidade Federal de Pernambuco, como requisito parcial para a obtenção do título de mestre em Ciência da Informação.
\end{abstract}

Aprovada em: 20/02/2019

\section{BANCA EXAMINADORA}

\author{
Profa D Da Nadi Helena Presser (Orientadora) \\ Universidade Federal de Pernambuco
}

Prof. Dr. Murilo Artur Araújo da Silveira (Examinador Interno)

Universidade Federal de Pernambuco

Prof. Dr. Gustavo Henrique de Araújo Freire (Examinador Externo)
Universidade Federal do Rio de Janeiro 
Para meu filho Gabriel, meu maior estímulo para a busca do aperfeiçoamento, em todas as áreas da minha vida. 


\section{AGRADECIMENTOS}

Toda minha gratidão a todos que, direta ou indiretamente, contribuíram para as reflexões e a elaboração do estudo aqui apresentado, em especial:

A Nadi Helena Presser, pela valorosa orientação e pelos rumos desta pesquisa;

Aos professores do PPGCI/UFPE, especialmente Májory, Fábio Pinho e Leilah Bufrem, pelo compartilhamento de seus conhecimentos e estímulo ao pensamento crítico;

Aos membros da banca, professores Murilo Silveira e Gustavo Freire, pelas valiosas contribuições que enriqueceram substancialmente este trabalho;

Aos colegas de turmas anteriores do PPGCI, pelas dicas e auxílios, sobretudo a Alejandro Caballero, pela generosidade no ensino de técnicas de visualização e mineração da informação;

Aos colegas do lbama, pelas discussões que motivaram e subsidiaram este trabalho, especialmente a Amaro, pela ajuda na coleta de dados, e a Tirza e Lisânia, pela amizade e exemplo de dedicação ao serviço público;

Aos queridos amigos Marcos Galindo, Stella e Ana Cláudia, pelo incentivo e motivação decisivos para meu ingresso no mestrado;

A minha família, muito especialmente a minha mãe, pelo apoio durante toda a vida e pela paciência nesses meses de presença limitada; e

Aos queridos colegas da melhor turma de mestrado que eu poderia desejar, em especial Rúbia e Sandryne, pelo compartilhamento de textos, ideias, angústias e conquistas. 
É perigoso e temerário que o cidadão médio continue a ignorar o aquecimento global, por exemplo, ou a diminuição da camada de ozônio, a poluição do ar, o lixo tóxico e radioativo, a chuva ácida, a erosão da camada superior do solo, o desflorestamento tropical, o crescimento exponencial da população. Os empregos e os salários dependem da ciência e da tecnologia. (SAGAN, 2009, p. 209) 


\section{RESUMO}

Trata-se de estudo de caso que analisa a informação produzida nas atividades finalísticas e registrada nos sistemas informacionais do Instituto Brasileiro do Meio Ambiente e dos Recursos Naturais Renováveis (Ibama) como recurso para a gestão da organização. As atividades do lbama englobam informações de diversas naturezas, dentre elas: informações sigilosas, provenientes do trabalho de investigação e inteligência, que servem de base para as ações estratégicas das atividades de fiscalização; informações gerenciais, que servem para o planejamento institucional e subsidiam as respostas aos órgãos de controle interno e externo, como é o caso das solicitações do Ministério Público; informações relativas aos estudos de impacto ambiental, que compõem processos de licenciamento ambiental; informações relativas às auditorias no sistema do Cadastro Técnico Federal. A ênfase da análise se concentrou nas informações produzidas pela Superintendência do Ibama em Pernambuco e armazenadas nos dois sistemas mais utilizados pelo Ibama, o Sistema Integrado de Cadastro, Arrecadação e Fiscalização (Sicafi) e o Sistema Eletrônico de Informações (SEI), no período compreendido entre 2013 e 2017. O estudo buscou resposta para o seguinte problema de pesquisa: como a informação produzida pelo Ibama e armazenada em seus sistemas informacionais pode contribuir como recurso para gestão da organização? Mais especificamente, a pesquisa teve por objetivos: mapear a informação produzida e armazenada pelos sistemas de informação do Ibama; demonstrar o potencial de uso dessas informações como recursos de gestão; e propor diretrizes para otimizar a gestão da informação no lbama. Caracterizada como pesquisa aplicada e descritiva, faz uso da observação-participante. A coleta de dados nos sistemas informatizados compreendeu: no Sicafi, os dados de Autos de Infração lavrados em Pernambuco, e no SEI, os dados relativos aos processos com demandas de trabalhos técnicos solicitadas ao Ibama pelo Ministério Público das esferas federal e estadual. Na pesquisa documental, foram consultados documentos institucionais do lbama e dispositivos legais relativos ao tema. Como ferramenta de análise, fez uso de técnicas de visualização da informação. Quanto à análise dos dados, antes de tudo, analisar as informações dos processos finalísticos pressupõe refletir sobre o contexto social do Ibama e examinar os fatores econômicos, políticos, ambientais que interferem e influenciam na gestão da organização e no comportamento informacional dos usuários. Como resultado, apresenta 
possibilidades de manipulação dos dados, através da visualização da informação, e sugestões para a melhoria da gestão da informação no Instituto.

Palavras-chave: Gestão da Informação. Comportamento Informacional. Ibama. Contexto Social. 


\section{ABSTRACT}

This is a case study with the objective of analyzing the information produced in the final activities and recorded in the informational systems of the Brazilian Institute of Environment and Renewable Natural Resources (Ibama) as a resource for the management of organization. Ibama's activities encompass information of various natures, including: confidential information, from the research and intelligence work, which serve as a basis for the strategic actions of the supervisory activities; Managerial information, which serves for institutional planning and subsides responses to internal and external control bodies, as is the case of requests from the Public Prosecutor's Office; Information regarding environmental impact studies, which comprise environmental licensing processes; Information regarding audits in the system of the Federal Technical Register. The emphasis of the analysis was concentrated on the information produced by the Superintendence of Ibama in Pernambuco and stored in the two systems most used by lbama, the Integrated System of Registration, Collection and Surveillance (Sicafi) and the Electronic System of Information (ESI), in the period between 2013 and 2017 . The study sought to answer the following research problem: how can the information produced by lbama and stored in its information systems contribute as a resource for the organization's management? More specifically, the research had as objectives: to map the information produced and stored by Ibama's information systems; demonstrate the potential of using this information as management resources; and propose guidelines to optimize information management in Ibama. Characterized as applied and descriptive research, it makes use of participant-observation. The data collection in the computerized systems comprised: in the Sicafi, the data of Notice Infraction Issued in Pernambuco, and in the ESI, to the data related to the processes with demands of technical works requested to Ibama by the Public Prosecutor's Office of the federal and state spheres. In the documentary research, Ibama's institutional documents and legal devices related to the subject were consulted. As an analysis tool, it made use of information visualization techniques. As for data analysis, first of all, analyzing the information of the final processes presupposes reflecting on lbama's social context and examining the economic, political, and environmental factors that interfere and influence the management of the organization and informational behavior of users. As a result, it presents possibilities 
for data manipulation through the visualization of information, and suggestions for the improvement of information management in the Institute.

Key-words: Information management. Information behavior. IBAMA. Social Context. 


\section{LISTA DE FIGURAS}

Figura 1 - Ciclo de Gestão da Informação proposto por Choo (1998) ................... 36

Figura 2 - Mapa do comportamento humano em informação............................... 41

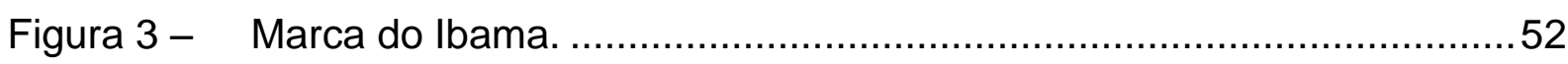

Figura 4 - Mapa estratégico do Ibama para o período de 2016 a 2019...............58

Figura 5 - Página de relatório gerado pelo Sicafi............................................. 72

Figura 6 - Primeira página com o resultado da pesquisa no SEI.........................73

Figura 7 - Exemplo de registro com falhas na leitura do texto..............................74

Figura 8 - Exemplo de Auto de Infração lavrado pela Fiscalização .......................80

Figura 9 - Distribuição geográfica das autuações de 2013 a 2017, nos municípios

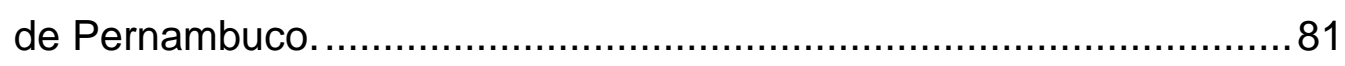

Figura 10 - Distribuição geográfica por tipo de infração, nos municípios de

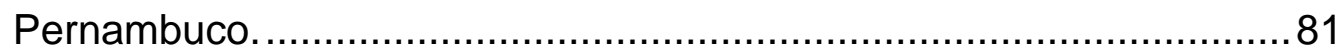

Figura 11 - Quantidade de Autos de Infração lavrados por ano ........................... 82

Figura 12 - Variação da quantidade de Al por tipo de infração .............................. 82

Figura 13 - Valores totais das multas aplicadas por ano ..................................... 83

Figura 14 - Valores totais das multas aplicadas por ano e por tipo de infração ......83

Figura 15 - Exemplo de metadados de processo no SEI. ......................................86

Figura 16 - Quantitativo por tipo de processo................................................. 87

Figura 17 - Quantitativo de processos por assunto. ………............................ 87

Figura 18 - Percentual de demandas por esfera do Ministério Público. ..................88

Figura 19 - Relação entre tipo de processo e MP solicitante. ………………....... 88

Figura 20 - Percentual de demandas relacionadas a processos do Ibama............ 88 


\section{LISTA DE QUADROS}

Quadro 1 - Estrutura organizacional da Superintendência do lbama em

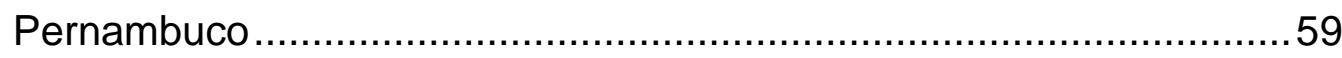

Quadro 2 - Atribuições dos setores finalísticos da Supes/PE ............................60

Quadro 3 - Processos de trabalho das atividades-fim da Supes/PE.....................64

Quadro 4 - Relação dos documentos institucionais do lbama consultados. ...........68

Quadro 5 - Relação dos dispositivos legais relativos ao lbama. .............................69

Quadro 6 - Relação dos campos de dados dos processos coletados no SEl. ........85

Quadro 7 - Extrato da planilha do Apêndice C. ............................................... 89

Quadro 8 - Propostas para a gestão da informação no lbama.............................103 


\section{LISTA DE ABREVIATURAS E SIGLAS}

ADA Ato Declaratório Ambiental

Al Auto de Infração

Al-e Auto de Infração Eletrônico

CAR Cadastro Ambiental Rural

CF Constituição Federal

CGTI Coordenação-Geral de Tecnologia da Informação

$\mathrm{Cl} \quad$ Ciência da Informação

COAD-PE Núcleo de Comunicação Administrativa em Pernambuco (Protocolo)

CTF/AIDA Cadastro Técnico Federal de Atividades e Instrumentos de Defesa Ambiental

CTF/APP Cadastro Técnico Federal de Atividades Potencialmente Poluidoras ou Utilizadoras de Recursos Naturais

Diafi Divisão de Administração e Finanças

Ditec Divisão Técnico-ambiental

Doc.lbama Sistema Informatizado de Gestão Documental

DOF Documento de Origem Florestal

ENAP Escola Nacional de Administração Pública

GED Gerenciamento eletrônico de documentos

Gl Gestão da Informação

Ibama Instituto Brasileiro do Meio Ambiente e dos Recursos Naturais Renováveis

IBDF Instituto Brasileiro de Desenvolvimento Florestal

ICMBio Instituto Chico Mendes de Conservação da Biodiversidade

LAI Lei de Acesso à Informação

MMA Ministério do Meio Ambiente

MPF Ministério Público

MPF Ministério Público Federal

MPOG Ministério do Planejamento, Orçamento e Gestão

MPPE Ministério Público do Estado de Pernambuco

NLA Núcleo de Licenciamento Ambiental

NQA Núcleo de Qualidade Ambiental

Nubio Núcleo de Biodiversidade e Florestas

Nufis Núcleo de Fiscalização Ambiental

OCR Optical Character Recognition (Reconhecimento ótico de caracteres) 
ONU Organização das Nações Unidas

PDF Portable Document Format (Formato Portátil de Documento)

PDTIC Plano Diretor de Tecnologia da Informação e Comunicação

PNMA Política Nacional de Meio Ambiente

Posic Política de Segurança da Informação, Informática e Comunicações

Prevfogo Núcleo de Prevenção e Combate aos Incêndios Florestais

RIF

Regulamento Interno da Fiscalização Ambiental

RQMA Relatório de Qualidade do Meio Ambiente

SEI Sistema Eletrônico de Informações

Sema Secretaria do Meio Ambiente

SFB Serviço Florestal Brasileiro

SIC Serviço de Informações ao Cidadão

Sicafi Sistema Integrado de Cadastro, Arrecadação e Fiscalização

SIGAD Sistema Informatizado de Gestão Arquivística de Documentos

$\mathrm{SIH} \quad$ Serviços de Informação Humanos

Sinaflor Sistema Nacional de Controle da Origem dos Produtos Florestais

Sisnama Sistema Nacional do Meio Ambiente

Sudepe Superintendência de Desenvolvimento da Pesca

Sudhevea Superintendência da Borracha

Supes/PE Superintendência do Ibama em Pernambuco

TIC Tecnologia de Informação e Comunicação

TRF4 Tribunal Regional Federal da $4^{\underline{a}}$ Região 
1 INTRODUÇÃO

1.1 OBJETO DE ESTUDO E LOCUS DA PESQUISA …..................................

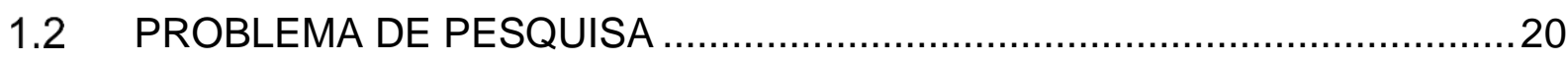

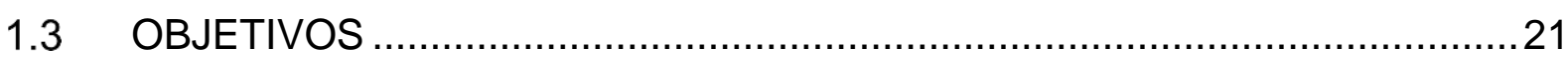

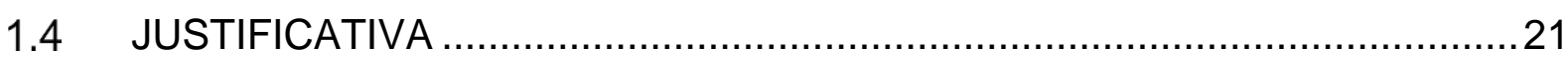

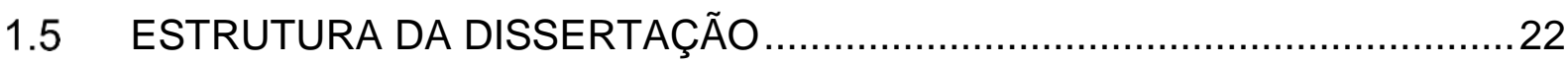

2 QUADRO TEÓRICO DE REFERÊNCIA ...............................................24

2.1 DOCUMENTO E INFORMAÇÃO; CI E ARQUIVOLOGIA ............................24

2.1.1 $O$ documento na administração pública: meio de prova ..........................26

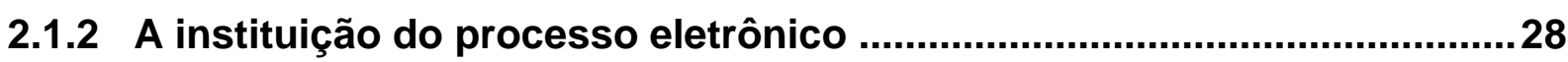

2.1.3 Gerenciamento eletrônico de documentos ............................................32

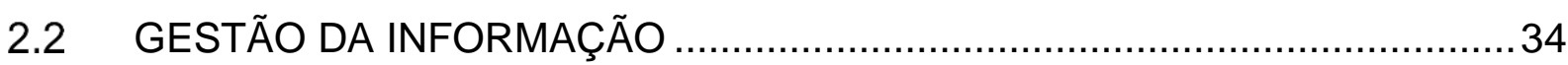

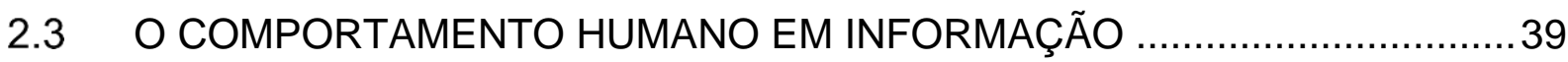

2.3.1 A racionalidade $e$ a intencionalidade no comportamento informacional 40

2.3.2 Evitar a informação e a irracionalidade no comportamento

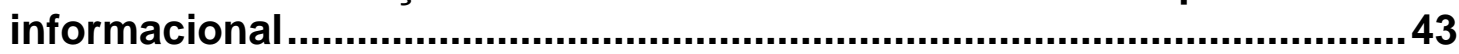

2.3.3 Ignorância e comportamento humano em informação ….........................45

2.3.4 O contexto social e o comportamento em informação ..............................47

3 O IBAMA NO CONTEXTO DO SERVIÇO PÚBLICO BRASILEIRO ..............52

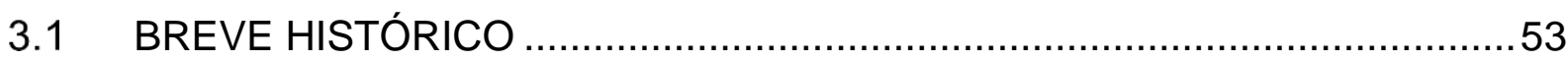

3.2 ESTRUTURA CENTRAL E UNIDADES DESCENTRALIZADAS ..................58

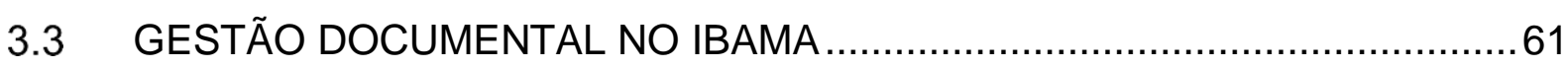

3.4 PROCESSOS DE TRABALHO E SISTEMAS DE INFORMAÇÃO ..................64

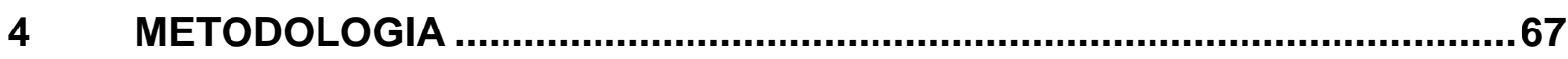

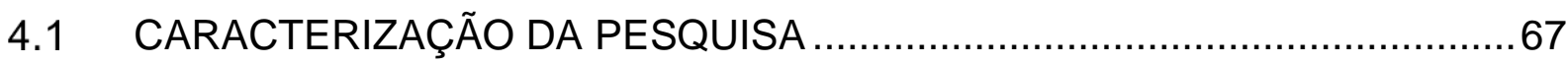

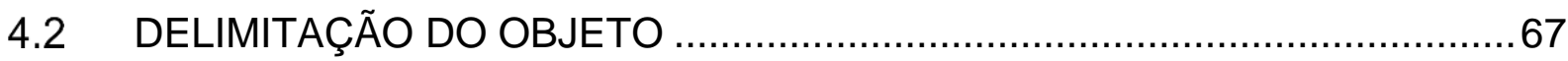

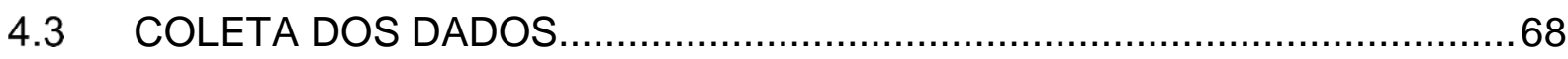

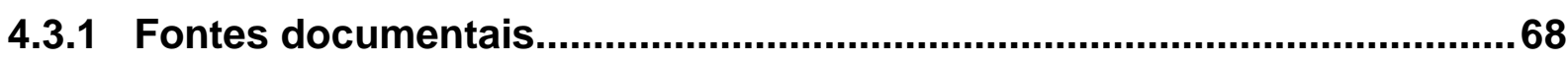

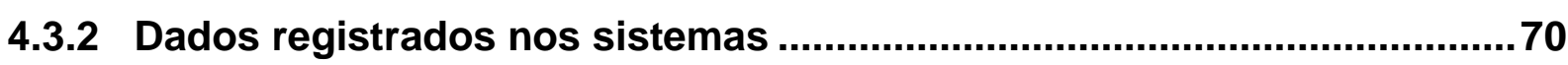

4.4 ANÁLISE DOS DADOS - VISUALIZAÇÃO DA INFORMAÇÃO.....................75 


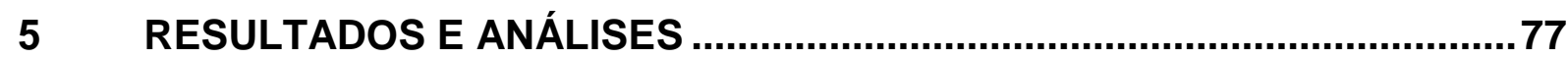

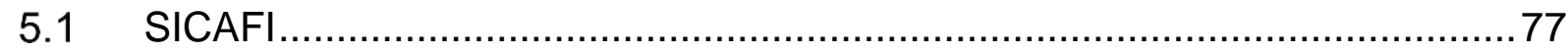

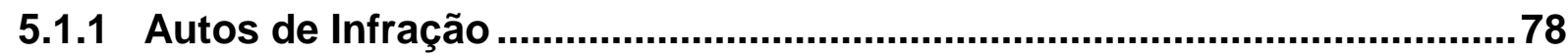

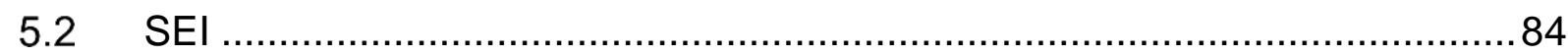

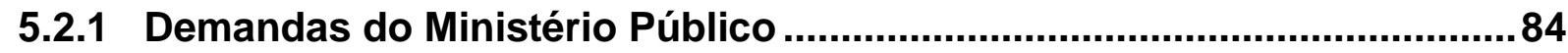

5.2.2 Indexação pelo usuário e recuperação da informação ..............................91

5.3 IBAMA - CONTEXTO, SISTEMAS E GESTÃO DA INFORMAÇÃO ...............93

5.4 PROPOSTAS PARA A GESTÃO DA INFORMAÇÃO NO IBAMA ...............100

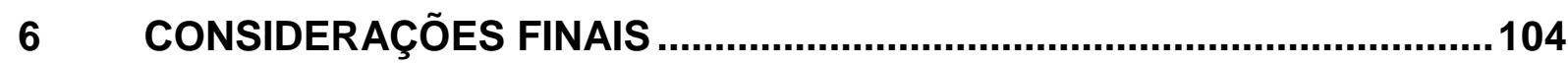

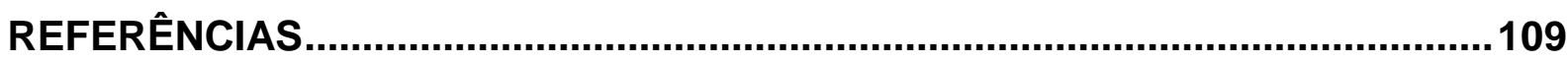

APÊNDICE A - TRAMITAÇÃO DOS PROCESSOS DE AUTO DE INFRAÇÃO ....120 APÊNDICE B - PLANILHA DE DADOS COLETADOS DO SICAFI.......................121 APÊNDICE C - PLANILHA DE DADOS COLETADOS DO SEI.............................150 ANEXO A - SISTEMAS DE INFORMAÇÃO DO IBAMA …...................................155 


\section{INTRODUÇÃO}

A ausência de uma política de gestão da informação dentro dos órgãos públicos, aliada à precariedade da organização do acervo arquivístico, comumente levam à dependência das memórias individuais (ou memória tácita) dos servidores de determinada instituição para responder às necessidades informacionais que surgem no dia a dia, em detrimento à pesquisa nos documentos e processos existentes - ou até para identificar aqueles que guardam o registro da informação desejada.

Essa realidade foi bem retratada pelo trabalho de Souza (1997), apresentando um cenário formado por "arquivos montados nos setores de trabalho e massas documentais acumuladas" (SOUZA, 1997, p. 31). Nesse artigo, o autor apresenta um diagnóstico bem detalhado do panorama arquivístico encontrado na grande maioria dos órgãos públicos brasileiros, que está longe de corresponder aos arquivos idealizados pelos teóricos da Arquivística. Mesmo passados mais de vinte anos e com a crescente informatização dos processos na última década, observa-se que os problemas se perpetuam, ou mesmo se agravam, uma vez que então o acervo documental divide-se entre eletrônico (disponível no sistema informatizado), e em papel, encontrando-se este último em condições cada vez mais precárias e de difícil acesso.

Por outro lado, a crescente cobrança da sociedade quanto à transparência e à agilidade nas respostas do poder público - resultando, inclusive, na edição da Lei de Acesso à Informação (Lei no 12.527/2011), entre outras iniciativas - expõe cada vez mais as deficiências do serviço público quanto à gestão da informação que ela mesma produz, além de uma cultura organizacional carente de práticas de compartilhamento do conhecimento acumulado por seus servidores.

Nesse contexto, a compreensão da tramitação dos processos de trabalho das organizações tem por finalidade colocar em evidência a origem, o processamento e o destino das informações geradas na execução desses processos. Assim, o tema central desta pesquisa constitui-se na gestão da informação (GI), cujo núcleo de investigação é a própria informação.

Segundo o Glossário Geral de Ciência da Informação. ${ }^{1}$, gestão da informação é um processo cíclico de trabalho com a informação, apoiado pela tecnologia, que deve

\footnotetext{
1 Glossário geral de Ciência da Informação, disponível no site http://www.cid.unb.br/. Acesso em 15 mar. 2017.
} 
ser realimentado continuamente, e que engloba, além da identificação de necessidades de informação, a aquisição, a organização e armazenamento, o desenvolvimento de produtos e serviços, a distribuição e o uso da informação. Todavia, Le Coadic (2004) salienta que o uso é o objetivo final de um produto de informação ou de um sistema de informação e deve ser pensado em termos da utilização da informação e dos efeitos resultantes desses usos nas atividades dos usuários. Assim, a utilização da informação no planejamento, no processo decisório e na execução das atividades cotidianas se coloca como uma das principais questões deste debate.

Mas, se o uso é o objetivo final de um sistema de informação e as pessoas são as responsáveis pelo manuseio das informações; logo, o que também se quer debater neste estudo é aquilo que na Ciência da Informação $(\mathrm{Cl})$ se define como comportamento humano em informação (WILSON, 2000; JOHNSON, 2009) - que diz respeito à predisposição das pessoas em buscar, avaliar e usar a informação para resolver problemas ou tomar decisões. Ademais, o que também se quer investigar neste estudo é aquilo que Tarapanoff (2007) define como cultura informacional, que diz respeito à sensibilização dos indivíduos ou grupos para o compartilhamento e o uso da informação em seu contexto social.

Na medida em que a informação cria condições propícias para o conhecimento, o processo de conhecer é investigado e necessita ser observado sob a ótica do comportamento humano em informação. Mas, como observa Johnson (2009), na Cl, o estado da arte do processo de busca de informação tem o lado racional praxiológico coberto, mas não se tem uma compreensão abrangente de todos os processos possíveis. Nas análises desse autor, os estudos sobre comportamento em informação muitas vezes foram enraizados em contextos mais racionais, como as bibliotecas, onde os indivíduos vêm com um problema definido, ou nos sistemas de tecnologia da informação, que possuem sua própria lógica inerente.

As tentativas de aplicar essa investigação em outros contextos muitas vezes se deparam com achados distintos, relacionados aos benefícios da ignorância e à aparente irracionalidade do comportamento humano em informação (SPINK; COLE, 2001), tentando explicar porque alguns gestores evitam ou ignoram informações relevantes no processo de gerir estoques informacionais gerados pelas próprias organizações (CASE et al, 2005). Outros pesquisadores que investigaram a busca e o uso de informação em contextos do dia a dia, das pessoas e das organizações, 
descobriram situações em que há um encontro aleatório e imprevisível com a informação (ERDELEZ, 1997) ou um encontro acidental com a informação, outro tema recorrente na busca de informação (CASE, 2006; JOHNSON, 1996; WILLIAMSON, 2005). Como destaca Fourie (2013), enquanto nos concentramos fortemente no que deve ser ganho com a provisão de informação, também raramente argumentamos em termos do que é perdido se as necessidades de informação não são cumpridas.

No contexto do serviço público, as informações produzidas são registradas nos documentos gerados por cada órgão, na forma de ofícios, memorandos, laudos, pareceres, notas técnicas e tantos outros, que posteriormente irão compor processos administrativos. Tais processos significam, portanto, a formalização do conhecimento organizacional. Assim, observa-se que os profissionais trabalham sistematicamente baseados em informações registradas nos processos sobre os quais atuam. Contudo, a importância da gestão da informação não se faz presente apenas nas esferas operacional e institucional, mas em âmbito global, na análise da conformidade da gestão e das demandas de órgãos de controle e dos resultados para os avanços das políticas públicas do país.

\subsection{OBJETO DE ESTUDO E LOCUS DA PESQUISA}

Esta pesquisa tem como foco de observação o Instituto Brasileiro do Meio Ambiente e dos Recursos Naturais Renováveis (Ibama). O objeto de análise é a informação produzida e registrada no desenvolvimento das atividades finalísticas do Ibama e armazenado nos seus sistemas informacionais para ser usado na execução do trabalho.

As atividades do Ibama englobam informações de diversas naturezas, as quais situam-se como um dos instrumentos centrais dos processos, dentre elas:

a. As informações sigilosas, provenientes de processos de investigação e inteligência, que servem de base para as ações estratégicas da Fiscalização;

b. As informações gerenciais, que têm por finalidade o controle de respostas aos órgãos externos, como é o caso das solicitações do Ministério Público;

c. As informações relativas aos estudos de impacto ambiental, que compõem processos de licenciamento;

d. As informações registradas no sistema do Cadastro Técnico Federal de Atividades Potencialmente Poluidoras ou Utilizadoras de Recursos Naturais 
(CTF-APP), que são a base para o Relatório de Qualidade do Meio Ambiente (RQMA), publicado periodicamente pelo Ibama e que sintetiza as "informações ambientais para a gestão dos recursos naturais e conservação dos ecossistemas em nosso país"?

O estudo de caso está ambientado na Superintendência do Ibama em Pernambuco (Supes/PE), figurando esta como uma amostra que possibilita a reflexão sobre todas as unidades descentralizadas do Instituto no Brasil, uma vez que as atividades desenvolvidas são comuns a todas as superintendências. A análise se concentra nas informações armazenadas nos dois sistemas utilizados pelo lbama que armazenam o maior volume dados: o Sistema Integrado de Cadastro, Arrecadação e Fiscalização (Sicafi) e o Sistema Eletrônico de Informações (SEI). Para delimitação da amostragem, foram consultadas informações registradas no período de 2013 a 2017.

\subsection{PROBLEMA DE PESQUISA}

Com base no exposto, este estudo busca responder o seguinte problema de pesquisa: como a informação produzida pelo lbama e armazenada em seus sistemas informacionais pode contribuir como recurso para gestão da organização?

Ponjuán Dante (2011) enfatiza as necessidades e expectativas dos usuários no que diz respeito aos sistemas informacionais. Segundo a autora, os usuários constituem o centro de qualquer sistema de informação e, portanto, é fundamental entender quem são os usuários,

isto é, ter clareza e transparência dentro do sistema de quem são os que se beneficiam da atividade principal do sistema. Portanto, obter informações acerca desses usuários e suas necessidades constitui um elo básico na operação do sistema e orienta os principais processos que nele ocorrem. (PONJUÁN DANTE, 2011, p. 15, tradução nossa).

Logo, a análise da informação produzida e armazenada pelo lbama refere-se essencialmente à relação dos usuários com os sistemas, ou seja, como eles registram, buscam e utilizam em seu trabalho cotidiano as informações presentes nesses

\footnotetext{
2 Fonte: $h$ ttp://ibama.gov.br/relatorios/qualidade-ambiental/relatorio-de-qualidade-do-meio-ambienterqma-relatorio-de-qualidade-do-meio-ambiente-rqma. Acesso em 01.jul.2018.
} 
sistemas. Assim, o propósito da gestão da informação é dar condições ao lbama para servir à sua própria finalidade.

\subsection{OBJETIVOS}

O objetivo geral desta pesquisa é analisar a informação produzida nas atividades finalísticas e registrada nos sistemas informacionais do lbama como recurso para a gestão da organização.

Mais especificamente, os objetivos são:

a. Mapear a informação produzida e armazenada pelos sistemas de informação do Ibama;

b. Demonstrar o potencial de uso dessas informações como recursos de gestão;

c. Propor diretrizes para otimizar a gestão da informação no lbama.

\subsection{JUSTIFICATIVA}

O potencial e os limites do uso da informação produzida e armazenada pelo Ibama só podem ser analisados dentro do seu contexto social. Como as pessoas usam a informação para formular, definir ou reivindicar suas realidades sociais deve ser o foco para conduzir esforços desta investigação. Tal perspectiva fortalece o mérito do paradigma sociocognitivo da Ciência da Informação (HJØRLAND, 1996).

Na concepção de Presser e González (2017), entre outros fatores, as normas sociais delimitam e indicam que tipos de informações são compartilhadas e quais são retidas. As normas sociais são costumes, valores e todos os outros critérios de conduta que são padronizados em um meio social ou em uma organização e que afetam a troca de informações, "[...] isto que elas definem parâmetros e agem como pontos de referência em torno do processo informacional". (PRESSER; GONZÁLEZ, 2017, p. 28). Fazer uma análise na dimensão social é compreender como a informação produzida e armazenada pelo Ibama se constitui como uma base para contribuir com sua missão: "Proteger o meio ambiente, garantir a qualidade ambiental e assegurar a sustentabilidade no uso dos recursos naturais, executando as ações de competência federal" (IBAMA, 2016, p. 2). 
Ademais, a pesquisa aqui apresentada justifica-se fundamentalmente pelas necessidades e dificuldades de recuperação das informações institucionais encontradas diariamente, tanto no trabalho cotidiano dos técnicos, quanto nas solicitações de informações feitas pelos usuários dos serviços do lbama, auditoria interna e externa e cidadãos em geral. Observa-se que, em alguns casos: a informação é imprecisa, pelo registro de dados incorretos para caracterizar determinado processo; não é completa, pois não são registrados todos os dados importantes para identificar um processo; e, consequentemente, não é confiável, uma vez que informações confiáveis dependem de seu registro fidedigno.

Assim, ratifica-se a afirmação de que

[...] a ciência da informação deve se preocupar não apenas com a informação científica e tecnológica, mas também, e em igual medida, com a informação pública, com a informação social; deve interessarse pelas tecnologias, embora não as tendo como imprescindíveis, ou seja, seu campo abarca ações, práticas, fazeres, pesquisas, estudos e reflexões em que elas estejam ou não presentes. (FADEL et al, 2010, p. 18-19).

Este projeto está, ainda, em consonância com o Plano Estratégico do lbama (2016), alinhando-se especialmente aos objetivos estratégicos 7 e 13, quais sejam:

OE 7: Prover dados e informações ambientais: Qualificar os dados e gerar valor na informação disponibilizada à sociedade, assim como fortalecer a avaliação e o monitoramento integrado da qualidade ambiental;

OE 13: Aprimorar a gestão da informação e do conhecimento: Desenvolver e/ou melhorar os sistemas existentes visando à efetiva sistematização e integração dos dados ambientais e sua disponibilização tanto para subsídio de gestão e tomada de decisão pelas entidades do SISNAMA quanto para a sociedade, visando à prestação de serviços de qualidade aos usuários, a garantia da qualidade ambiental e a proteção do meio ambiente, assegurando o desenvolvimento sustentável.

\subsection{ESTRUTURA DA DISSERTAÇÃO}

O presente trabalho está assim estruturado: nesta seção, a introdução, foi apresentado o tema, os elementos que permitem caracterizar o objeto de estudo e o locus de análise, assim como o problema de pesquisa e seus objetivos, bem como a justificativa do trabalho. 
A seção 2 trata do quadro teórico de referência, discorrendo sobre os principais conceitos que amparam a pesquisa. A seção 3 , da metodologia, traz a caracterização da pesquisa e detalha os métodos utilizados para alcançar os objetivos enumerados anteriormente. A seção 4 apresenta brevemente o lbama, sua estrutura organizacional, a sua evolução quanto à gestão documental e seus sistemas de informação.

Na seção 5 são apresentados os resultados e análises frutos da pesquisa, enquanto a seção 6 traz as considerações finais e sugestões para pesquisas futuras. 


\section{QUADRO TEÓRICO DE REFERÊNCIA}

O quadro teórico desta pesquisa está estruturado em três partes. Primeiro, reflete-se sobre a relação da Ciência da Informação $(\mathrm{Cl})$ com a Arquivologia, sobre o documento e a gestão documental, especialmente no âmbito da administração pública brasileira. Em seguida, trazendo ao debate os aportes teóricos da $\mathrm{Cl}$, busca-se uma fundamentação sobre o que define a gestão da informação na constituição das informações produzidas pelas organizações. Por fim, discorre-se acerca das teorias sobre o comportamento humano em informação e as variáveis que influenciam em tal comportamento.

\subsection{DOCUMENTO E INFORMAÇÃO; CI E ARQUIVOLOGIA}

A literatura especializada frequentemente cita a origem da Ciência da Informação $(\mathrm{Cl})$ nas ciências documentais - a Biblioteconomia, a Arquivística e a Museologia -, embora posteriormente a $\mathrm{Cl}$ tenha adquirido corpo próprio e se emancipado como área do conhecimento (SILVA; FUJITA; DAL'EVEDOVE, 2009). Essa relação é evidenciada ao observar-se o documento como "o termo genérico que designa os objetos portadores de informação" (LE COADIC, 2004, p. 5), enquanto a informação se constitui como "um conhecimento inscrito (registrado) em forma escrita (impressa ou digital), oral ou audiovisual, em um suporte" (ibid., p. 4).

Fundamentadas nas práticas relacionadas à organização e gestão de seus acervos (biblioteca, arquivo ou museu), as ciências documentais desenvolveram seus aportes teóricos a partir de uma perspectiva essencialmente funcionalista, consolidando-se como disciplinas científicas (ARAÚJO, 2014); no entanto, não há clareza quanto às delimitações entre os campos dessas ciências e da $\mathrm{Cl}$. Isso porque, ao expandir seus estudos para a relação de seus acervos com a sociedade em que estão inseridos - por exemplo, com estudos de usuários e de comportamento em informação das pessoas - há uma clara afinidade com as pesquisas no campo da $\mathrm{Cl}$, a qual, por sua vez, frequentemente encontra nos acervos e registros documentais seus objetos de estudo. Sobre isso, o professor Carlos Alberto Araújo explica:

[...] Informação, objeto de estudo da ciência da informação, constitui, antes de tudo, um conceito, uma categoria abstrata, que só pode ser compreendida e estudada por meio do estudo de outros fenômenos, 
estes sim, com existência concreta, material, na esfera da realidade humana. (ARAÚJO, 2014, p. 157).

Uma vez que este trabalho tem como foco as informações registradas em sistemas informatizados, invariavelmente trata também dos documentos ali armazenados e, por conseguinte, aproxima-se do campo de estudo da Arquivologia. Neste ponto, é importante destacar que, ao mesmo tempo em que o avanço tecnológico (especialmente relativo à Ciência da Computação) e a explosão informacional do século XX impulsionaram os estudos que deram origem à Ciência da Informação, também impuseram à Arquivologia uma mudança conceitual e paradigmática. Assim:

O objeto da arquivologia, na perspectiva de um novo paradigma, desloca-se do "arquivo" para a informação arquivística, ou "informação registrada orgânica", expressão cunhada por arquivistas canadenses para designar a informação gerada pelos processos administrativos e por eles estruturada de forma a permitir uma recuperação em que o contexto organizacional desses processos seja o ponto de partida. Para Thomassen, este é um objeto duplo, uma vez que se refere à informação arquivística (conteúdo semântico do documento) e ao seu contexto gerador, ou seja, o processo de criação dos documentos (conteúdo diplomático do documento). (FONSECA, 2005, posição 997-1002).

Nesse sentido, Vitoriano (2017) destaca que essa "percepção de que o suporte e a informação registrada não são mais 'inseparáveis' aproxima a Arquivologia da Ciência da Informação" (VITORIANO, 2017, p. 61). Amorim (2011) ressalta, no entanto, que não há consenso entre os pares sobre as fronteiras e intersecções entre a $\mathrm{Cl}$ e a Arquivologia, sendo ainda necessário muito diálogo entre as duas áreas do conhecimento.

Por outro lado, Fonseca (2005) alerta que as relações interdisciplinares entre a Arquivologia e a Ciência da Informação é mais evidente no cenário brasileiro do que em outros países, onde, tradicionalmente, a Arquivística relaciona-se mais estreitamente com programas de pós-graduação em História. Para a autora, essa relação com a $\mathrm{Cl}$ "parece ser uma característica da evolução da área arquivística no Brasil" (FONSECA, 2005, posição 2227).

Nesse contexto, Araújo (2014) defende que a relação conflituosa entre as áreas por vezes se dá em razão da "oposição entre a dimensão reflexiva e a dimensão aplicada" (ARAÚJO, 2014, p. 167), mas que, considerando-as como ciências 
humanas e sociais, é possível haver uma interlocução frutífera para todas as partes, observando-se a singularidade e complexidade dos fenômenos estudados.

Em contrapartida,

[...] importante frisar que a $\mathrm{Cl}$ constitui um campo específico do conhecimento. Nesta vertente, a mesma não possui um único objeto, mas problemas informacionais dentro de um contexto social, político, cultural e social amplo e complexo que necessita ser investigado a partir de questões apresentadas pela ciência e pela sociedade. (SILVA; FUJITA; DAL'EVEDOVE, 2009, p. 284).

Nesse sentido, destacamos que este trabalho não se propõe a analisar o conteúdo dos documentos registrados nos sistemas informacionais, mas sim o que tais documentos representam enquanto registro das atividades e do conhecimento acumulado pela organização.

\subsubsection{O documento na administração pública: meio de prova}

As atividades cotidianas desenvolvidas no serviço público são comumente registradas por meio de documentos escritos, na forma de ofícios, memorandos, relatórios, laudos, pareceres, notas técnicas, ordens de serviço e tantos outros, que posteriormente poderão ou não compor processos administrativos. Nas palavras de Alves (2017, p. 14),

Os documentos se constituem, desde muito, a principal ferramenta e um dos principais insumos da máquina pública para consecução de seus objetivos. É com eles que qualquer atividade burocrática se desenvolve e são neles que estão guardados os registros, as provas e os testemunhos das atividades do Estado, bem como os direitos conquistados pelos cidadãos.

Toda essa documentação vem a constituir a memória institucional e, mesmo quando não se trata de uma instituição memorial - que tem por objetivo a preservação de acervos, tais como museus, arquivos ou bibliotecas - a preservação e organização dos documentos produzidos é fundamental para a evolução do conhecimento sobre suas atividades finalísticas. Em uma organização governamental, a memória institucional representa também meios de prova no âmbito administrativo e judicial, além de ser a base para a construção de políticas públicas. Ou seja,

Os documentos públicos são peças que estão integradas num todo, orgânico e estruturado, que lhes conferem sentido de existir, ou seja, a razão de ser da própria administração. Significa dizer que o documento só preserva seu valor quando está integrado num conjunto 
próprio, que reflete o contexto de sua produção, que expressa o valor probatório sobre o funcionamento do governo e o exercício dos direitos e deveres do cidadão. (RODRIGUES, 2013, p. 65).

No Brasil, a obrigação do Estado com a preservação documental está consolidada nos termos da Lei o 8.159/1991, que trata da Política Nacional de Arquivos e em seu artigo 1ำ estabelece: "É dever do Poder Público a gestão documental e a proteção especial a documentos de arquivos, como instrumento de apoio à administração, à cultura, ao desenvolvimento científico e como elementos de prova e informação". A mesma lei define a gestão documental como "o conjunto de procedimentos e operações técnicas referentes à sua produção, tramitação, uso, avaliação e arquivamento em fase corrente e intermediária, visando a sua eliminação ou recolhimento para guarda permanente".

Entretanto, colocar em prática essa legislação é um dos grandes desafios enfrentados pela administração pública, uma vez que a realidade aponta para uma massa documental gigantesca e crescente, em sua maior parte acondicionada em condições precárias e com pouca ou nenhuma organização.

A duplicidade de registros é um fator que colabora para o aumento do volume da massa documental. Isso porque - talvez mesmo em razão da precariedade do arquivo institucional - a "regra" geral é que cada servidor monte seu arquivo próprio, com cópias dos trabalhos nos quais tenha colaborado. E quando, por qualquer motivo, a instituição faz uso desses "arquivos pessoais" para atender a uma demanda informacional, em detrimento ao que deveria ser o arquivo geral - onde dificilmente é possível encontrar alguma coisa - isso só reforça, no imaginário dos servidores, a importância de se manter esses arquivos paralelos.

Sousa (1997) aponta que os arquivos correntes, tais como definidos pelas teorias da Arquivística, não podem ser aplicados na maior parte dos locais de trabalho da administração pública brasileira. O que existe, de fato, é o acúmulo de documentos nos setores, em sua maioria réplicas dos que se encontram nos "arquivos" oficiais, que, por sua vez, consistem basicamente de massas documentais acumuladas. Cada setor organiza seus arquivos com base em conceitos próprios dos servidores, não havendo qualquer norma ou método comum que reja essa organização.

Por outro lado, não significa que os métodos empíricos e improvisados pelos quais os setores de trabalho organizam seus documentos não funcionem. Eles são suficientes para atender às principais necessidades. Paradoxalmente, esses métodos 
não garantem que o arquivamento e a busca à informação contida nos arquivos sejam acessíveis a todos. Em cada setor, o funcionário responsável pela documentação imprime uma característica própria ao método, o que impossibilita a sua operação por outras pessoas. A ausência daquele dificulta ou, muitas vezes, impede a recuperação da informação. A melhoria das condições de organização dos arquivos só é lembrada quando se procura uma informação e esta não é encontrada. Os documentos não são eliminados, mas também não são tratados de forma técnico-científica (SOUSA, 1997).

As condições precárias de guarda dos arquivos institucionais é outro componente da realidade da administração pública brasileira. Os documentos são comumente armazenados em salas ou galpões de condições insalubres, frequentemente apresentando problemas nas instalações elétricas e hidráulicas e com ventilação inadequada ou inexistente. Sousa (1997, p. 12) demonstra, ainda, que "a burocracia brasileira entende, quase sempre, os arquivos como uma atividade sem muito prestígio, na qual são alocados funcionários sem nenhuma qualificação ou problemáticos". Há também o fato de que os arquivos, em razão dessa pouca valorização, recebem parcos recursos para sua manutenção, o que, com o passar do tempo, somente agrava a situação.

Infelizmente, o cenário aqui apresentado ainda retrata a realidade na maior parte das instituições públicas brasileiras - à exceção, espera-se, daquelas que têm como finalidade a preservação de seus acervos, tais como museus, arquivos e bibliotecas públicas.

\subsubsection{A instituição do processo eletrônico}

A despeito do quadro descrito acima, acompanhando a evolução das tecnologias da informação e com a natural modernização dos serviços, iniciou-se na última década, dentro da administração pública, a substituição gradual dos documentos e processos em papel pelos processos eletrônicos. Vale ressaltar que não se trata meramente dos sistemas de gestão documental, que acompanham o movimento dos documentos dentro das instituições e que são comuns desde os anos 1980, mas sim dos sistemas que possibilitam a criação e tramitação dos processos integralmente em meio digital, sem a utilização do papel durante todo o seu período de tramitação e arquivamento (excetuando-se, eventualmente, a necessidade de envio de correspondências externas a pessoas físicas ou jurídicas). 
Nesse sentido, a implantação do processo eletrônico no Brasil originou-se por iniciativa do Poder Judiciário, com a publicação da Lei n 11.419/2006, que previa a informatização dos processos judiciais em todas as suas fases. Antes disso, desde o ano 2000, o Diário Oficial da União já era publicado integralmente em formato digital, possibilitando o seu acesso de qualquer lugar e por qualquer cidadão em todo o mundo ${ }^{3}$.

O juiz e professor de Direito Carlos Henrique Abrão (2013) relata as dificuldades enfrentadas pelo Poder Judiciário para modernização dos serviços, envolvendo desde questões técnicas a barreiras culturais, tanto por parte da sociedade, quanto dos servidores e dos próprios magistrados. Cabe destacar que não se trata simplesmente da digitalização dos processos físicos, mas sim da mudança de toda uma cultura voltada para a materialização dos documentos em papel, com a novidade de que grande parte dos documentos, assinados digitalmente, passam a existir somente em meio eletrônico: petições, atas, decisões, entre tantos outros.

Evidentemente, uma mudança desse porte exige um grande esforço e recursos investidos na estrutura de informática, como também no treinamento de pessoal. No entanto, são inegáveis os avanços e economia: de tempo para todas as partes envolvidas, uma vez que elimina a necessidade de comparecimento pessoal aos fóruns para peticionar ou ter acesso às decisões; de material (papel, impressões, capas de processo, caixas-arquivo etc.); e, sobretudo, de espaço e condições para armazenamento da grande massa documental gerada anualmente.

Bem se observa, antes de tudo, que a formatação do processo eletrônico depende de recursos, sistemas, banco de dados, armazenamento, certificação digital, encerrando um conjunto de atividade meio e atividade fim para que o jurisdicionado se coloque como incluído no sistema inaugurado pela maioria das Cortes do país. (ABRÃO, 2013, p. 53).

Com a oficialização do processo eletrônico pelo Judiciário, extinguiam-se as dúvidas quanto à legitimidade e legalidade dos documentos assinados digitalmente, e anunciava-se uma nova era dentro do serviço público brasileiro, abrindo espaço para que a tecnologia do processo eletrônico pudesse ser adotada em todas as esferas da administração pública.

3 Fonte: http://portal.imprensanacional.gov.br/acesso-a-informacao/institucional/a-imprensa-nacional. Acesso em 25.maio.2018 
Além disso, o compartilhamento de tecnologias também vem facilitando a adoção do modelo por instituições que dificilmente teriam recursos para investir em sistemas que pudessem garantir a segurança e a eficiência exigidos para a implantação do processo eletrônico. Um grande exemplo desse fato é o Sistema Eletrônico de Informações - $\mathrm{SEI}^{4}$, que foi inicialmente desenvolvido pelo Tribunal Regional Federal da 4⿳亠丷a Região (TRF4) e cedido gratuitamente para utilização de outros órgãos públicos, que podem igualmente desenvolver módulos para agregar novas funcionalidades ao sistema e assim garantir a atualização do software para todos os órgãos que o adotarem. Sob a gestão do Ministério do Planejamento, Orçamento e Gestão (MPOG) ${ }^{5}$, o SEl já foi adotado como solução para gestão documental em mais de cem instituições do Poder Executivo Federal, além de tantas outras nas esferas estadual e municipal.

Uchôa (2014) relata o processo de implantação do SEI no MPOG, o qual veio a servir de referência para os demais órgãos do Executivo Federal que aderiram ao sistema. Na metodologia apresentada pelo autor, destaca-se a elaboração de "fluxos de alto nível" para os processos (em vez de mapas processuais excessivamente detalhados), bem como a gestão de riscos e questões de infraestrutura de rede. Além disso, ressalta a necessidade de colaboração entre profissionais de diversas áreas do conhecimento no processo de planejamento e implantação da solução:

Como se depreende, em que pese o fundo tecnológico da solução, não se trata de um projeto cuja implantação possa ser entregue apenas aos profissionais de tecnologia da informação. Não obstante a solução tenha como objeto a gestão de documentos arquivísticos, não se trata de um projeto que exija a predominância de profissionais da área de documentação e arquivo. E em que pese o claro fundamento da solução na gestão orientada por processos, especialistas nesse campo de conhecimento são fundamentais, mas precisam atuar de forma colaborativa com profissionais de outras áreas. Conhecimentos em todos esses campos e em vários outros, como o jurídico, de acesso à informação, de relacionamento com órgãos de controle, gestão de pessoas, mostram-se todos imprescindíveis à implantação do SEI, em uma integração poucas vezes tão necessária para a implantação de um projeto, que poderá estabelecer um novo marco na administração pública brasileira. (UCHÔA, 2014, p. 19).

No entanto, em que pese os avanços proporcionados pelo SEl em relação à produção de documentos e acesso aos processos, há uma grande preocupação da

\footnotetext{
${ }^{4}$ Mais informações: https://softwarepublico.gov.br/social/sei/sobre-o-sei. Acesso em 15.jun.2017.

${ }^{5}$ A partir de 2019, a estrutura do Ministério do Planejamento foi integrada ao Ministério da Economia.
} 
comunidade arquivística acerca do tratamento dado aos documentos após a implantação do sistema nos órgãos públicos, sobretudo em função do descolamento entre a operação do sistema e a (in)existência de uma política arquivística nas instituições.

Diante desse quadro, o Arquivo Nacional designou um grupo de trabalho com o objetivo de avaliar a aderência do SEI às diretrizes do e-ARQ Brasil ${ }^{6}$ e do MoreqJus ${ }^{7}$, concluindo o seguinte:

1) A presente versão do SEI não atende satisfatoriamente aos requisitos necessários para apoiar as atividades de gestão arquivística dos documentos por ele produzidos e mantidos;

2) O SEl necessita funcionar como um SIGAD ${ }^{8}$ ou atuar conjuntamente com um SIGAD específico, a fim de que se possa realizar o controle do ciclo vital por meio de procedimentos de gestão arquivística de documentos.

3) Para que o SEI possa atuar como um SIGAD são necessários que se procedam diversos ajustes, sendo prioritário:

- controle dos documentos avulsos;

- autuação dos processos, somente quando necessário;

- captura dos documentos arquivísticos e arquivamento;

- apoio para as atividades de avaliação e destinação;

- apoio para as atividades de monitoramento com vistas à preservação digital.

4) O órgão ou entidade que adotar o SEI, ou qualquer outro sistema informatizado para a produção de documentos digitais, já deve ter implantado uma política e um programa de gestão de documentos.

5) O órgão ou entidade que adotar o SEI, ou qualquer outro sistema informatizado para a produção de documentos digitais, precisa prever uma política de preservação digital para garantir o acesso de longo prazo a estes documentos. (ARQUIVO NACIONAL, 2015, p. 8-9).

Um dos pontos questionados é o tratamento de todos os fluxos de trabalho como processos, não havendo tratamento diferenciado para documentos avulsos que, a rigor, não teriam necessidade de integrar um processo, tal como havia no sistema físico. Esse formato diverge da lógica documental/processual consagrada

\footnotetext{
${ }^{6}$ e-ARQ Brasil: Modelo de Requisitos para Sistemas Informatizados de Gestão Arquivística de Documentos. Disponível em: <http://www.siga.arquivonacional.gov.br/images/publicacoes/e-arq.pdts. Acesso em 15.nov.2018.

7 Moreq-Jus: Modelo de Requisitos para Sistemas Informatizados de Gestão de Processos e Documentos do Poder Judiciário. Ver: <http://www.cnj.jus.br/programas-e-acoes/pj-proname/sistemamoreq-jus>. Acesso em 15.nov.2018.

8 SIGAD - Sistema Informatizado de Gestão Arquivística de Documentos. "As principais funcionalidades de um SIGAD são: classificação e organização dos documentos com base no plano ou código de classificação, controle da temporalidade, aplicação da destinação, manutenção da autenticidade e apoio à preservação de longo prazo." (ARQUIVO NACIONAL, 2015, p. 10-11).
} 
pela Arquivística, que impacta sobretudo na questão da guarda ou descarte da massa documental. Ainda é cedo para prever que impacto essa política de armazenamento indiscriminado (em formato digital) terá sobre a guarda e recuperação da informação.

Outra preocupação relevante refere-se aos metadados de identificação dos processos e documentos, uma vez que no SEl somente a numeração de identificação dos documentos atende às recomendações, sendo que todos os demais metadados não seguem qualquer padrão nacional ou internacional. A avaliação do Arquivo Nacional destaca, no entanto, que o SEI pode ser evoluído gradativamente para incorporar as recomendações e os requisitos necessários.

Em editorial da Revista Brasileira de História, Venancio e Feitler (2018) alertam sobre os perigos do que eles chamam de "uma política antiarquivística" disseminada com a implantação do SEI nos órgãos públicos, bem como projetos de lei que tramitam no Legislativo, destacando o perigo do descarte indiscriminado de documentos originais após a digitalização. Os autores advertem que tal problema não se refere aos documentos nato-digitais (aqueles que são criados em meio eletrônico), mas sim aos documentos originados em papel e posteriormente digitalizados para inclusão no sistema. De fato, não há orientação clara quanto ao destino dos documentos originais após sua digitalização e inclusão no sistema. Para aqueles recebidos por terceiros, orienta-se que sejam devolvidos aos interessados.

\subsubsection{Gerenciamento eletrônico de documentos}

Em meio às discussões sobre a política arquivística adotada pelos órgãos públicos, convém trazer ao debate algumas questões acerca do gerenciamento eletrônico de documentos (GED), o qual compreende todas as operações arquivísticas relacionadas ao ciclo de existência dos documentos armazenados em um sistema eletrônico, desde a captura (digitalização), indexação (descrição e metadados), armazenamento e disponibilização da informação (OLIVEIRA, 2014).

Como não poderia deixar de ser, a garantia de autenticidade dos documentos - sejam eles digitalizados a partir de originais impressos ou produzidos dentro do próprio sistema eletrônico - é uma preocupação básica nesse processo, com vistas à garantia da confiabilidade do sistema. Para isso, o sistema de GED deve atender a diversos critérios de segurança: 
A idoneidade de um sistema eletrônico de gerenciamento arquivístico é garantida por dois métodos: um referente à prevenção e outro à verificação. O primeiro inclui limitação de acesso à tecnologia que envolve o sistema e definição de regras de workflow. A limitação de acesso consiste na criação de privilégios de acesso por meio de senhas, cartões magnéticos, impressões digitais etc. As regras de workflow definem o que será feito e como será feito, de tal maneira que procedimentos administrativos e documentários estejam integrados. Quanto ao método de verificação, este consiste no estabelecimento de uma trilha de auditoria, ou seja, de um mecanismo que permite registrar todas as intervenções feitas no documento, as quais incluem modificar, apagar, acrescentar ou simplesmente ver o documento. Nesse sentido, o método de verificação se constitui também em garantia de autenticidade do documento arquivístico. (RONDINELLI, 2005, posição 998)

Outro ponto que demanda bastante cuidado diz respeito à indexação dos documentos no sistema (sobretudo os digitalizados), cuja descrição por meio de metadados é essencial para a sua identificação e impacta significativamente na recuperação da informação.

Em termos da análise diplomática, o chamado perfil do documento (ou metadado) é considerado uma anotação e, portanto, compõe a forma intelectual do documento arquivístico. Trata-se de um conjunto de informações anexadas ao documento eletrônico no momento em que o sistema recebe uma ordem para enviá-lo ou salvá-lo. Seu objetivo é identificar o documento individualmente e estabelecer a sua relação com os demais documentos integrantes do dossiê. (ibid., posição 914918).

Nesse contexto, há uma preocupação ainda maior quando a indexação passa a ser feita pelo usuário não qualificado, e não mais por profissionais especializados ou dos setores de protocolo. De acordo com Silva e Smit (2009), essa facilidade e flexibilidade proporcionadas pelos sistemas eletrônicos para que os usuários insiram documentos, com os respectivos metadados, implicam em maior agilidade na disponibilização desses documentos, mas também dificultam consideravelmente o processo de recuperação da informação. Isso porque não há homogeneidade no preenchimento dos campos, prejudicando a identificação de equivalência dos dados, bem como a interoperabilidade dos sistemas (SILVA; SMIT, 2009). Para esses autores, é necessário o aperfeiçoamento das mediações do sistema com os usuários, a fim de implantar mecanismos de controle alinhados com os princípios de organização da informação.

$\mathrm{Na}$ mesma direção, Pavão et al (2015) defendem que a qualidade dos metadados é o que garante que o documento será recuperado, possibilitando também 
a interoperabilidade dos sistemas e a mineração de dados. Esse fator, aliado à organização da informação e a uma interface simples e amigável, implica diretamente na qualidade da gestão da informação dentro da organização, a curto e longo prazo (PAVÃO et al, 2015).

\subsection{GESTÃO DA INFORMAÇÃO}

No campo da Cl há uma farta literatura de conceitos e modelos de gestão da informação nas organizações, como, por exemplo, Le Coadic (2004), Beal (2004) e Davenport (1998). Embora com alguma variação quanto aos elementos ou processos envolvidos, invariavelmente a gestão da informação está relacionada ao "ciclo" ou "fluxo da informação", composto, basicamente, pelos elementos: produção, comunicação e uso (LE COADIC, 2004) ${ }^{9}$. Não raro, o armazenamento e a recuperação integram esse ciclo, que pode vir a incorporar também outros processos, conforme o enfoque e o nível de detalhamento defendido por cada autor, mas sempre com o objetivo de disponibilizar as informações para atender às necessidades de uso das pessoas e organizações (PONJUÁN DANTE, 2011).

Entretanto, perdura a questão de quão bem informados estão os gestores para melhor decidir e agir, e serem de fato competitivos nas suas áreas de atuação (FREITAS; JANISSEK-MUNIZ, 2006). Os modelos existentes nem sempre respondem à complexidade que se interpõe ao uso da informação. O potencial do uso das informações armazenadas nos diversos sistemas informacionais das organizações é vasto, mas essa questão nem sempre é analisada a partir dos fatores contextuais que cercam e afetam os fluxos de produção, comunicação e uso da informação.

Freitas e Janissek-Muniz (2006) distinguem os fluxos informacionais fluindo em três direções:

a. Informação circulando internamente - do e para o interior da organização;

b. Informação sendo comunicada ou divulgada - do interior da empresa para o exterior da organização;

c. Informação sendo recebida ou buscada - do exterior da empresa para o interior da organização.

\footnotetext{
9 Para outros conceitos, além dos apresentados neste trabalho, ver os trabalhos referenciados, em especial Beal (2004) e Davenport (1998).
} 
No processo de gerir informações, Davenport (1998) salienta observar:

a. Os valores e as crenças dos gestores - cultura em informação;

b. Como as pessoas realmente usam a informação e o que fazem com ela - o comportamento em informação;

c. As armadilhas que podem interferir no intercâmbio de informações - o contexto, em especial, a atuação das forças políticas nos processos de informação;

d. Quais sistemas de informação já estão instalados - as tecnologias de informação.

Igualmente, McGee e Prusak (1994, p. 106) salientam que "[...] a maneira como os indivíduos se comportam em relação à informação - como eles a adquirem, selecionam, analisam e a comunicam - é tão importante para a organização quanto a própria informação".

Seguindo Frohmann (1992), esse discurso remete à construção social dos processos de informação, seja se constituindo de necessidades de informação do usuário ou padrões de produção, distribuição e consumo de informação. Assim sendo, segundo esse autor, a visão da identidade dos usuários de informação como dadas, como quer o paradigma cognitivo, deveria mudar de posição para investigar as instabilidades dos usuários, devido às suas condições de alternância em um campo agonístico de forças, interesses e importantes referências sociais, políticas, econômicas e culturais.

Não obstante, Presser e González (2017) pressupõem considerar a produção histórica e social de um determinado grupo social, evidenciar a cultura nos processos de construção, comunicação e uso da informação. Apreender o usuário de informação como culturalmente constituído subentende operar dentro de uma perspectiva em que a pessoa nunca é idêntica a si mesma por todo o sempre. Assim, embora determinados grupos tentem permanentemente impor práticas sociais como certas, os movimentos de contestação também são permanentes. (PRESSER; GONZÁLEZ, 2017, p. 24-25).

Choo (1998) concebe a gestão da informação em um conjunto de seis processos inter-relacionados: identificação de necessidades informacionais, coleta de informação, organização e armazenamento da informação, desenvolvimento de produtos e serviços de informação, disseminação e uso da informação. O ciclo tem 
um propósito de tornar acessíveis as informações que são relevantes ao negócio da organização. A Figura 1 mostra o ciclo informacional proposto por Choo (1998).

Figura 1 - Ciclo de Gestão da Informação proposto por Choo (1998).

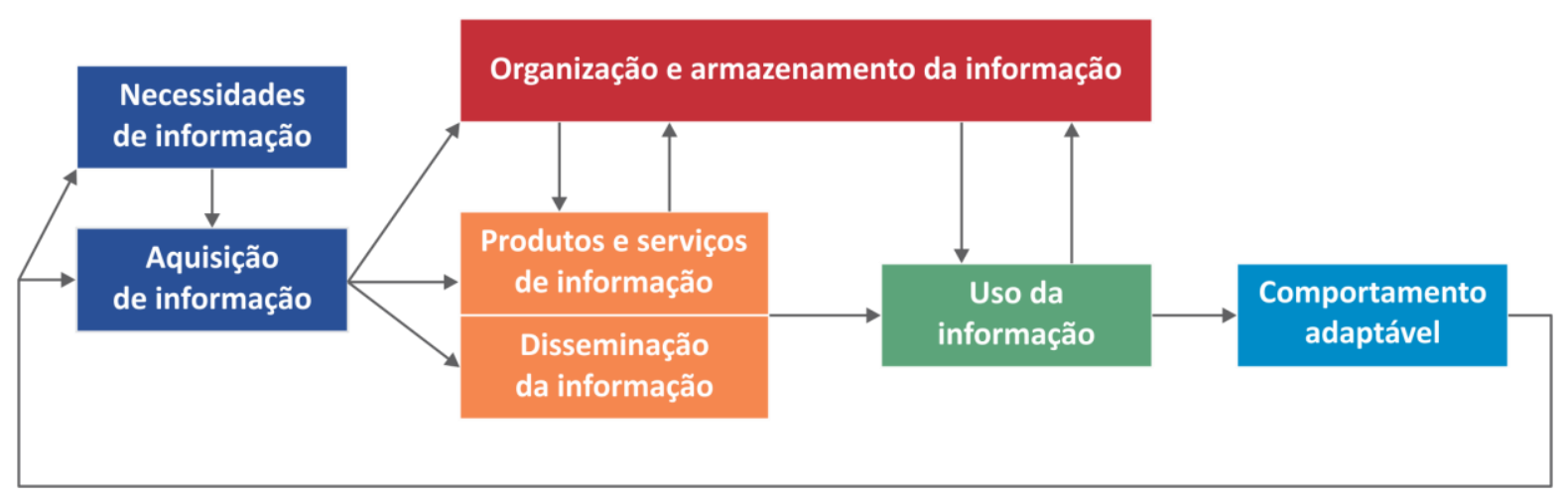

Fonte: Adaptado de Choo (1998).

Assim como na proposta de Choo (1998) na Figura 1, a identificação das necessidades de informação também constitui a primeira etapa do fluxo informacional na concepção de Beal (2004), Le Coadic (2004) e Davenport (1998). O que se lê nesses autores é que a informação é sempre exigida para a realização de uma necessidade mais fundamental, cumprir um objetivo, realizar uma ação, embora a mesma não precise ser imediata.

Segundo Le Coadic (2004), as necessidades de informação surgem em função do conhecimento ou em função da ação. O primeiro caso relaciona-se à curiosidade (científica ou não) e à vontade de conhecer, inerente ao espírito humano. Já as necessidades em função da ação dizem respeito à informação como meio a realização de uma atividade profissional ou individual. É, portanto, este segundo tipo que se relaciona com a informação organizacional, objeto deste trabalho.

Uma vez que as organizações contemporâneas se caracterizam pela contínua produção, processamento e uso da informação, pode-se considerar que os processos críticos da gestão da informação designam a organização e o tratamento da informação, como mostra Choo (1998) na Figura 1 e ressaltam outros autores como Barbosa (2008). Com efeito, o crescente volume de informações processadas por intermédio de sistemas informacionais das organizações evidencia a importância da tecnologia para armazenar a informação dos documentos, de forma a possibilitar a sua futura recuperação. Por outro lado, descobrir onde se encontra a informação, bem 
como qual a melhor estratégia de compartilhamento, caracterizam aspectos essenciais para a gestão da informação, como evidenciado por Choo (1998) na Figura 1.

A administração pública, locus deste estudo, se enquadra na denominada "administração burocrática", caracterizada pelos princípios da legalidade, impessoalidade, moralidade, publicidade e eficiência ${ }^{10}$. Tais princípios têm por objetivo a garantia do perfeito cumprimento da lei e dos direitos dos cidadãos, sem qualquer distinção entre eles. "No entanto, ao se observar a realidade do serviço público, vê-se o termo burocracia como sinônimo de ineficiência, lentidão e rigidez" (AMORIM; TOMAÉL, 2011, p. 76). Isso porque o excesso de formalismo e a necessidade de garantir o cumprimento da legislação, por vezes, resultam em processos lentos e com exigências excessivas, que mais atrapalham os interesses de quem quer exercer suas atividades legalmente, do que impedem a burla e a corrupção.

Segundo Amorim e Tomaél (2011), os sistemas de informações podem ser fortes aliados das organizações burocráticas, sobretudo no que diz respeito à eficiência e transparência dos serviços prestados. Para tanto, é essencial a mudança da cultura organizacional essencialmente patrimonialista e de controle do conhecimento, para uma cultura de compartilhamento de informação. Um dos grandes desafios é garantir que as pessoas utilizem os sistemas informatizados de maneira que todas informações sejam neles registradas (AMORIM; TOMAÉL, 2011). Com as novas tecnologias de comunicação, é necessário adequação aos novos meios de armazenamento e disseminação da informação, mas também o cuidado com o registro completo e preciso das informações. Em relação às organizações públicas, essa realidade se torna mais urgente, visto que as informações estarão disponíveis aos cidadãos em meios digitais, quase que instantaneamente, sem qualquer filtro ou seleção, e não no tradicional suporte em papel.

Uma vez que a entrada de dados, na maior parte das vezes, não é feita por especialistas, os sistemas de informação devem ser aprimorados para que sejam autoexplicativos e minimizem ao máximo os erros no preenchimento dos campos, observam Amorim e Tomaél (2011). Isso diz respeito, sobretudo, à usabilidade do sistema, mas também à capacitação das pessoas e à responsabilidade da organização em colocar pessoas com competências, habilidades e atitudes adequadas à função. Segundo esses autores, a implantação de um novo sistema de

${ }^{10}$ Art. 37 da Constituição Federal de 1988. 
informação necessariamente vai implicar em dificuldades até que os usuários estejam suficientemente familiarizados com o software. No entanto, o projeto do sistema deve ser feito com vistas a que ele venha a auxiliar seus usuários, e não se tornar um complicador na execução das atividades cotidianas.

Por outro lado, a dinamicidade na tramitação das informações é uma premissa da sociedade moderna e das organizações, especialmente de caráter público, "[...] que devem se adequar às necessidades da população." (ibid., 2011, p. 77). Para determinar quais as características da boa informação, as organizações precisam considerar não somente a informação que utilizam, mas também os processos que geram essas informações.

Além de serem instrumentos para disseminação de informação, os serviços e produtos de informação (ver Figura 1) são o resultado de todo o processo de gestão de informação, pois, como diz Rozados (2004), se traduzem na interface direta entre a informação e o usuário. Ponjuán Dante (2011) destaca que o sistema de informação existe para entregar uma saída desejada, ou seja, todo sistema é desenhado e configurado para fornecer um determinado resultado. "Os resultados dos sistemas de informação predominantes são produtos, serviços ou novas informações que são oferecidas ao usuário para atender às suas expectativas e necessidades." (PONJUÁN DANTE, 2011, p. 16, tradução nossa).

Quanto à tipologia de serviços de informação, Rozados (2004) apresenta dois grupos: os serviços de atendimento à demanda e os serviços de antecipação à demanda. Os primeiros, serviços de atendimento à demanda, são aqueles desenvolvidos sob encomenda, por exemplo, para atender demandas específicas dos usuários, como pedidos de informação ou relatórios de auditoria. Os serviços de antecipação à demanda, por sua vez, visam apontar possibilidades futuras de usos de informação, como se fossem necessidades informacionais ainda não expressas. Exemplo desse serviço são as publicações de dados abertos (do inglês open data), movimento que vem tomando força em todo mundo como forma de promoção da transparência e do controle social das ações governamentais ${ }^{11}$.

Entender como uma organização usa a informação é questão bastante complexa. Segundo Choo (2003), a informação é um componente intrínseco de quase tudo que uma organização faz. Por outro lado, os serviços ou produtos de informação

11 Ver: Portal Brasileiro de Dados Abertos (http://dados.gov.br/pagina/dados-abertos). 
devem ser definidos a partir do contexto social, considerando a possibilidade de este ser uma arena de disputas políticas e econômicas. Essa visão ampla do usuário de informação é que define as suas necessidades informacionais e expectativas com relação aos serviços ou produtos de informação, com vistas ao uso (também evidenciado na Figura 1 de Choo, 1998).

É nesse sentido que se justificam as críticas de Frohmann (1992), pois o que contam não são apenas necessidades individuais de informação de cada usuário, mas, antes de tudo, compreender o ambiente no qual esse usuário está inserido. Assim, o que Frohmann (1992) e os demais defensores do paradigma sociocognitivo defendem é considerar as características da organização na qual o usuário está operando, com relação a sua missão e aos seus objetivos estratégicos. Se não houver apropriação, por parte do gestor da informação, da dinâmica desse fluxo informacional, certamente não haverá eficácia no que tange aos resultados relativos ao uso da informação.

\subsection{O COMPORTAMENTO HUMANO EM INFORMAÇÃO}

O processo de gestão da informação está diretamente relacionado a como as pessoas se comportam nos processos de produção, busca e uso da informação (ver a última etapa da Figura 1 de Choo, 1998). Segundo Johnson (2009), só é possível compreender o comportamento em informação de acordo com o contexto, pois somente dentro de um contexto a informação fará sentido.

Aqui debate-se principalmente o elemento de comportamento humano em informação que recebeu a atenção acadêmica mais duradoura e substancial: a busca de informações (JOHNSON, 2009). No entanto, para compreendê-lo completamente, deve ser justaposto contra outras condições do comportamento em informação. Johnson (2009) também chama atenção para o fato de que a busca pela informação não representa um fim em si mesma, mas sim um meio para se atingir determinado objetivo, normalmente relacionado à execução de alguma ação.

Comportamento informacional, segundo Wilson (1999), é o resultado do reconhecimento de alguma necessidade de informação sobre determinado assunto sobre o qual se pretende adquirir conhecimento, e, portanto, o indivíduo realiza vários procedimentos de busca da informação para suprir essa lacuna. Mais tarde, Wilson (2000) amplia seu conceito, definindo comportamento em informação como "[...] a 
totalidade do comportamento humano em relação às fontes e canais de informação, incluindo a busca ativa e passiva de informação e uso da informação." (WILSON, 2000 , p. 49, tradução nossa). Em suma, "[...] é a busca intencional para obter informações como consequência de uma necessidade de satisfazer alguma meta" (ibid., p. 49).

O pensamento de Johnson (2009) estimula uma compreensão mais profunda da busca de informação, indo além dos contextos mais racionais, como as bibliotecas, onde os indivíduos vêm com um problema definido, ou nos sistemas de tecnologia da informação, que possuem sua própria lógica inerente.

\subsubsection{A racionalidade e a intencionalidade no comportamento informacional}

Johnson (2009) apresenta e leva ao debate várias teorias, conforme observase na Figura 2. O autor detalha seu posicionamento nos quadrantes (Q1, Q2, Q3 e Q4) formados pelos motivos para se evitar ou adquirir informação (eixo vertical) e pelas razões para a ocorrência do comportamento em informação de modo acidental ou intencional (eixo horizontal). Em suma, Johnson (2009) alerta que o estado da arte do processo de busca de informação tem o lado racional praxiológico coberto, mas não se tem uma compreensão abrangente de todos os quadrantes possíveis.

Observando a Figura 2, percebe-se que o eixo vertical é determinado pela relação da pessoa com a informação, com necessidades de informação frequentemente caracterizadas por estados motivacionais internos (CASE, 2006), mostrando se as pessoas desejam adquirir informações em uma extremidade ou estão motivadas para evitá-la, na outra. O eixo horizontal é determinado pela relação da pessoa com o suporte da informação e mostra se o encontro com a informação é proposital ou acidental (CASE, 2006).

O eixo vertical, segundo Johnson (2009), está fundamentalmente associado a questões de motivação e desejo, os motores geradores de busca de informação. Ainda segundo o autor, a aquisição geralmente é privilegiada nas culturas ocidentais, com ações vistas como mais virtuosas do que a passividade, duas palavras-chave na definição de comportamento humano em informação de Wilson (2000). 
Figura 2 - Mapa do comportamento humano em informação

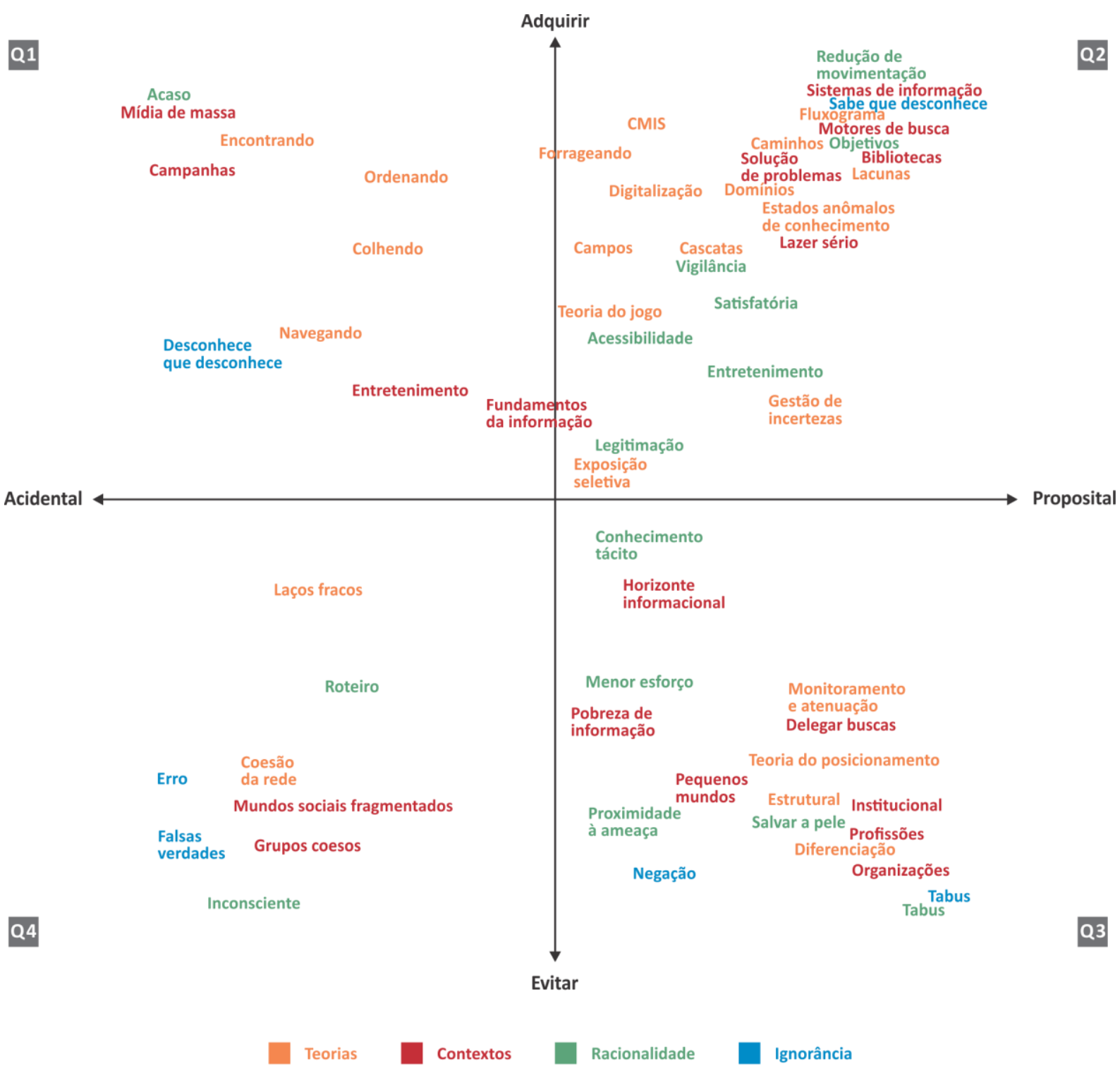

Fonte: Elaboração própria (2018), adaptado de Johnson (2009).

Pesquisas inseridas nesse eixo vertical reconhecem um espectro de definições de comportamento informacional, dentre eles, Wilson (2000), Case (2007; 2012), Fisher e Julien (2009), concebendo-o como busca ativa de informações, esforços conscientes, objetivos intencionais, busca motivada para solução de problemas, busca de informações semi-dirigidas, escolha de fontes de informação, preferências por fontes. A busca ativa de informações também está associada à mudança potencial, à questão central das pesquisas organizacionais no campo da administração, pois os processos de busca ativa podem levar os indivíduos a serem 
muito mais receptivos a qualquer informação que adquiram, resultando em maior probabilidade de ganho de conhecimento, mudança de atitude ou mudança de comportamento (JOHNSON, 1996). Um corolário importante disso é a persistência obstinada até que uma resposta de alta qualidade seja encontrada como 0 comportamento de busca ideal, observa Jonhson (2009). Este é também o reino da curiosidade - e até da obsessão.

Há também que se considerar o uso de modelos, como o processo de busca de informação de Kuhlthau $(1991$; 2004) que geralmente se encontram no quadrante 2 (Q2). O modelo centrado no indivíduo leva em consideração os sentimentos, pensamentos e ações que ocorrem durante os estágios de iniciação, seleção, exploração, formulação, coleção e apresentação (KUHLTHAU, 1991; 2004). Também os modelos de fluxogramas são restritos ao Q2.

Esses modelos clássicos de fase ou etapas quase sempre enfrentam problemas de forma empírica, uma vez que as pessoas não se engajam em abordagens ordenadas, sequenciais e mecanicistas dos problemas, avalia Johnson (2009). Outra fraqueza, segundo esse autor, é que assumem que as fontes profissionais autorizadas são as primeiras consultadas. Esses modelos oferecem interpretações racionais para problemas irracionais e, como resultado, não capturam a "florescente confusão" do mundo real (JOHNSON, 2009).

Assim, os quadrantes à direita (Q2 e Q3) centram-se na questão subjacente da intencionalidade, na extensão em que os indivíduos têm abordagens racionais de seu comportamento em relação aos suportes, um componente central do comportamento em informação (CASE, 2007). O lado direito do continuum horizontal subentende teleologia (explica a busca de informação pelo propósito que ela serve, explica a finalidade da busca) e um propósito para selecionar suportes, em particular. Os quadrantes à esquerda (Q1 e Q4) refletem aleatoriedade, acaso e destino. Qualquer exposição a informações úteis deste lado do continuum é vista como fortuita e casual.

Na concepção de Johnson (2009), as pesquisas na Cl são mais orientadas para os quadrantes superiores (Q1 e Q2) da Figura 2; sobretudo o Q2, que se concentra na busca de informações que trata, na sua própria definição, da aquisição intencional de informações. Nos quadrantes abaixo da linha horizontal (Q3 e Q4 da Figura 2), poucas tentativas foram feitas para desenvolver conceitos mais abrangentes (CASE et al., 2005). 
Contudo, determinar vínculos claros e ligados a fatores contextuais oferece o potencial de mover a pesquisa de busca de informações a partir do nível descritivo para um nível teórico mais explícito. Assim, à medida que os pesquisadores ampliaram suas pesquisas sobre busca de informação, eles entenderam que pode haver uma gama mais ampla de comportamento em informação. Além disso, tem havido uma apreciação crescente dos três problemas teóricos centrais e emergentes que qualquer desenvolvimento promissor que a teoria de comportamento em informação deve enfrentar: contexto, ignorância e irracionalidade.

\subsubsection{Evitar a informação e a irracionalidade no comportamento informacional}

No outro extremo do continuum do eixo vertical tem-se o comportamento de evitar a informação, visto como uma atitude quase covarde ou, no mínimo, preguiçosa (JOHNSON, 2009).

Embora a busca de informações organizacionais tenha sido um foco tradicional da Cl, Savolainen (1995; 2005) chamou a atenção para a variedade de domínios em que a busca de informações ocorre em nossas vidas no dia a dia. Essa atenção aumentada é refletida no International Information Seeking in Context Conferences (DERVIN, 1997). Essencialmente, esse movimento argumenta que uma visão ampliada dos contextos em que ocorre o comportamento em informação pode aprofundar a nossa compreensão (SAVOLAINEN, 1995). Também serve para sugerir os elementos ativos que podem servir como os fundamentos essenciais de explicações de contingência mais sofisticadas. Ao fazer isso, as coisas que não mudam de contexto para contexto destacam o que pode ser o invariante, o núcleo, o cerne essencial do comportamento em informação.

Uma concepção específica de um contexto de informação é a do campo de informação dentro do qual o indivíduo está incorporado (COOL, 2001). O campo de informação de um indivíduo fornece o ponto de partida para a busca de informações. Segundo Cool (2001), representa o arranjo típico dos estímulos de informação a que um indivíduo é exposto regularmente. De certa forma, na análise de Jonhson (2009), a totalidade dos campos de informação de alguém faz menção ao seu capital social, na medida em que descreve os recursos que um indivíduo precisa recorrer ao se confrontar com um problema. Quanto mais contextos sociais, políticos, econômicos 
ou legais compartilham pessoas e organizações, mais perto elas estão e é mais provável que elas estejam conectadas, relacionadas a determinados objetivos.

Todavia, o campo do comportamento em informação ainda enfrenta o pressuposto de que o comportamento em informação é altamente racional e dirigido a objetivos, observam Spink e Cole (2006). Na análise de Johnson (2009), a racionalidade pode estar no cerne de alguns dos "pressupostos duvidosos" incorporados na literatura articulada por Dervin (1976): há informações relevantes para cada necessidade, sempre é possível disponibilizar ou acessar a informação e as pessoas fazem conexões fáceis e sem conflitos entre informações externas, "objetivas" e sua própria realidade interna. Ou seja, segundo Jonhson (2009), a racionalidade reflete essencialmente motivos, causas e explicações aceitáveis e muitas vezes está profundamente enraizada nas tecnologias. Igualmente, para outros pesquisadores, o racional subentende pensar, pesar, refletir, enquanto a irracionalidade reflete intuições, emoção e subjetividade (NAHL; BILAL, 2007).

Como já vimos antes, grande parte da busca de informação da literatura ainda é baseada na redução da incerteza (KUHLTHAU, 2004), essencialmente uma redução dirigida (CASE, 2005) para atingir uma meta ou uma necessidade de informação, uma abordagem de solução de problemas, que é aceita como fundamentalmente racional. Esta é a força subjacente das lacunas de informação do estado anômalo de conhecimento de Brookes (1980) ${ }^{12}$. Nessas visões, a mera ignorância, por si só, não é tipicamente um motivador para a busca de informações. As pessoas só são motivadas a buscar informações quando elas sabem que são ignorantes e as informações que faltam se tornam salientes (JONHSON, 2009).

Outras teorias desafiam a racionalidade convencional ou pelo menos sugerem a necessidade de uma compreensão mais ampla disso, para articular motivos subjacentes menos racionais para a busca de informação. Jonhson (2009) cita o Princípio do Menor Esforço de Zipf (1949). Quanto menos esforço se gasta, menor probabilidade de se decepcionar ou arrepender com a escolha feita, com

\footnotetext{
${ }^{12}$ Brookes (1980) contribuiu para a construção do Paradigma Cognitivo, que tem como principal objeto de análise as estruturas de conhecimento dos usuários de informações. Na teoria do Estado Anômalo de Conhecimento (Anomalous State of Knowladge - ASK), Brookes (1980) defende que a busca por informação tem origem numa necessidade ou situação problemática no estado de conhecimento do indivíduo. Logo, para suprir esta necessidade, a pessoa se apropria da informação necessária para construir um novo conhecimento ou modificar um conhecimento já existente, e, desse modo, preencher as lacunas que estavam em aberto.
} 
maximizadores que dedicam o esforço ideal mais propensos a estarem deprimidos, infelizes, arrependidos e pessimistas (SCHWARTZ, 2004). Com maior esforço também vem maior responsabilidade pelas escolhas e pelos erros, afirma esse autor. De fato, ignorar pode ser uma estratégia muito racional, como pode ser o emprego do menor esforço para chegar a uma resposta. Do mesmo modo, as informações que ameaçam enfrentar o desempenho do trabalho podem não ser procuradas (ASHFORD; BLATT; VANDEWALLE, 2003).

Jonhson (2009) alerta que é necessária uma compreensão mais profunda da racionalidade para contestar alguns achados comuns na literatura sobre busca de informação. Alguns pesquisadores tendem a assumir que as pessoas irão gastar muita energia para atacar problemas importantes e, também, para assegurar a qualidade das fontes e das respostas - mas elas claramente não o fazem assim (CASE, 2006; JOHNSON 2009). Muitas vezes a acessibilidade das fontes é determinante fundamental do seu uso (BATES, 2005), mesmo para engenheiros altamente racionais. E a maioria dos buscadores vai parar de procurar quando descobrem a primeira resposta plausível à sua consulta. Pode, de fato, ser profundamente racional preservar a ignorância, para experimentar seus muitos benefícios (JOHNSON, 2009).

\subsubsection{Ignorância e comportamento humano em informação}

Ignorância e busca de informações são conceitos impossíveis de separar (JONHSON, 2009). Convencionalmente, diante das atitudes ocidentais em relação ao conhecimento e ao progresso, a ignorância é vista como algo que precisa ser superado. Jonhson (2009) define termos-chave, mapeando a ignorância em oito categorias separadas, desenvolvidas por Kerwin (1993) ao longo das duas dimensões fundamentais na Figura 2 (p. 41).

As coisas que sabemos que não conhecemos: as incógnitas conhecidas têm sido o objeto clássico da pesquisa de busca de informação. Elas também foram chamadas de ignorância consciente ou meta-ignorância. Talvez mais problemáticas sejam as coisas que não sabemos que nós não sabemos: as incógnitas desconhecidas. Estas são as coisas mais susceptíveis de resultar em surpresas e sacudidas ambientais. Erro, algo que pensamos que sabemos, mas não sabemos: é 
mais provável que seja corrigido por meio de interações com outros, especialmente ligações sem lógica.

Por sua vez, falsas verdades são coisas que são desconhecidas, mas que pensamos que sabemos. As falsas verdades muitas vezes formam a sabedoria convencional que é a base para as interações em curso, ainda assim, são visões errôneas do mundo e que, com alguns questionamentos fundamentais, podem ser derrubadas. A negação representa coisas que são muito dolorosos para saber, então não o fazemos.

As pessoas muitas vezes têm razões muito poderosas para se recusar a admitir que algo é verdadeiro, comenta Jonhson (2009). Talvez até mais problemáticos para os sistemas sociais sejam tabus, as coisas que as sociedades concordam que não devem ser conhecidas pelos seus membros porque ameaçam suas premissas subjacentes. A maioria das culturas tradicionais ao longo da história tem sido preservadores da verdade, em vez de perseguidores da verdade, com a busca de informações permitida em domínios muito limitados, muitas vezes altamente pessoais. O conhecimento proibido (por exemplo, domínios religiosos) é uma área para a qual existiam penalidades significativas para indivíduos que se envolviam em busca de informações (JOHNSON, 1996; 2009). A tendência de evitar, ignorar ou negar a informação sempre foi uma espécie de anomalia no comportamento humano. A ideia de "selecionar" mensagens de formas intencionais e planejadas naturalmente enfatiza a informação que é selecionada, não aquela que é ignorada.

A maioria das abordagens em relação à informação tende a se concentrar em seus muitos benefícios. Convencionalmente, diante das atitudes ocidentais em relação ao conhecimento e ao progresso, a ignorância é vista como algo que precisa ser superado. Nas organizações, às vezes, a ignorância é concebida para ser superada, vista como um dilema substancial. Mas a ignorância persiste porque é útil em vários níveis, se não uma necessidade para as organizações e seus membros e, dessa forma, mais profundamente, subversivamente racional. De fato, as forças que preservam a ignorância podem ser muito mais atraentes do que as resultantes da aquisição de conhecimento (HERSBERGER, 2005; JOHNSON, 1996). Tudo isso sugere que a ignorância pode ser sustentada por uma racionalidade subjacente mais profunda associada a seus muitos benefícios. 


\subsubsection{O contexto social e o comportamento em informação}

O que se se lê acerca das teorias dos quadrantes constantes na Figura 2 (p. 41) é o persistente problema teórico de considerar o usuário de informação isolado e atomizado, um foco maior nos atributos cognitivos racionais dos indivíduos, minimizando o mundo social dos contextos interpessoais.

Segundo as análises de Pettigrew; Fidel e Bruce (2000), as abordagens para estudar o comportamento informacional que se focam no contexto social emergiram lentamente durante o começo dos anos de 1990 e estão se tornando cada vez mais proeminentes. Com seus focos sobre os sentidos e valores associados com aspectos sociais, socioculturais, e sociolinguísticos de comportamento informacional, estudos baseados em estruturas sociais tendem a aplicar conceitos que têm ganhado popularidade dentro de comportamento informacional em geral. Diferente das teorias cognitivas, que tendem a objetivar contexto por evocá-lo e descrevê-lo como distinto, entidades factuais que são separadas do objeto de estudo, abordagens sociais consideram o contexto interpretativamente e holisticamente e o julgam como "portador de sentido" (TALJA; KESO; PIETILAINEN, 1999, p. 752).

A frente dessa mudança no foco a partir, primariamente, de fatores cognitivos para fatores sociais, culturais e afetivos é o trabalho de Chatman (2001). Ela desenvolveu três arcabouços para estudar comportamento informacional: (I) teoria de pobreza informacional, (II) teoria de vida no entorno ${ }^{13}$, e (III) teoria de comportamento normativo. Note-se que que Chatman (2001) também identificou que as pessoas evitam e ignoram informações, mas, para seus estudos, ela pegou emprestadas várias teorias das ciências sociais para estudar o fluxo de informação do dia-a-dia, em diferentes configurações contextuais.

De acordo com Chatman (2001), as pessoas vivem em um mundo empobrecido quando elas escolhem ignorar informação apesar de saberem que esta pode ser de ajuda para lidar com suas preocupações e problemas diários. Para manter uma impressão de se virar bem nos mundos de suas vidas, ela descobriu que mulheres idosas residindo em um complexo para aposentados se engajavam em comportamentos de autoproteção, que formavam os limites de seus mundos de pobreza informacional. Nesse sentido, a teoria explica como os indivíduos definem e usam

${ }^{13}$ NT: a autora usa originalmente a expressão: "theory of life in the round". 
suas experiências de vida para sobreviver em um mundo de grande desconfiança. Isso revela situações nas quais pessoas sabem que existem informações importantes, relevantes e potencialmente úteis, mas altos custos sociais as induzem a ignorá-las.

A análise do comportamento informacional de detentas em uma prisão de segurança máxima revelou que, embora esse mundo contenha um enorme grau de imprecisão, ele também é caracterizado por níveis surpreendentemente aceitáveis de incerteza (CHATMAN, 2001). A teoria de vida no entorno de Chatman compreende seis proposições, duas das quais declara que as pessoas não cruzarão fronteiras de seus pequenos mundos para buscar informação e que as pessoas cruzarão apenas fronteiras informacionais quando a informação é percebida como crítica, é coletivamente percebida como relevante e existe uma percepção de que a vida no entorno não funciona mais sem ela (id., 2001). Em essência, habitantes de um pequeno mundo escolherão ignorar informações se eles percebem que seu mundo está funcionando sem ela, ou seja, eles têm certeza, conforto e previsibilidade da situação o suficiente, de tal modo que a necessidade de informação é negada.

Em seu último arcabouço, teoria de comportamento normativo, Chatman (2001) se focou sobre a realidade do dia-a-dia de pessoas que compartilham um espaço cultural similar, caracterizado por eventos comuns ou rotineiros. O comportamento informacional (definido como estado em que uma pessoa pode ou não atuar sobre informação recebida) é definido pelas normas sociais. Normas sociais são padrões com os quais membros de um mundo social concordam a fim de exibir expressões desejáveis de comportamento público. As normas sociais, por sua vez, definem a visão de mundo, uma atitude coletiva, tomada como certa, que sensibiliza os membros a ser sensíveis a certos eventos e ignorar outros. O esforço de alguém para criar e manter esse tipo social afetará como alguém se envolve na busca por informação. Se a situação requer informação que é inconsistente com a visão de mundo estabelecida ou contradiz o tipo social estabelecido, então o indivíduo pode evitar e não se comprometer na busca por informação ou se mover a outro mundo social onde ele ou ela possa se envolver no comportamento mais livremente.

Na concepção de Presser e González (2017), entre outros fatores, as normas sociais delimitam e indicam que tipos de informações são compartilhadas e quais são retidas. As normas sociais são costumes, valores e todos os outros critérios de conduta que são padronizados em um meio social ou em uma organização e que afetam a troca de informações, "[...] isto que elas definem parâmetros e agem como 
pontos de referência em torno do processo informacional". (PRESSER; GONZÁLEZ, 2017, p. 28). O seu objetivo é dar um senso de equilíbrio ao mundo e, por isso, funcionam como códigos de comportamento. "O papel das normas é definir as informações que são legitimadas para buscar e apropriadas para compartilhar." (ibid., p. 20-21).

A influência da teoria de ciência social no desenvolvimento de estruturas sociais para comportamento informacional também é vista no trabalho de Tuominen e Savolainen (1997). Em essência, ao invés de enxergar a informação como uma entidade com limites fixados ou como uma mercadoria que é transferida por meio da comunicação, eles definiram informação como "um constructo comunicativo que é produzido em um contexto social" (TUOMINEN; SAVOLAINEN, 1997, p. 89). Como eles explicam depois:

A natureza contextual da informação significa que o modo no qual uma versão da informação é construída sempre depende da natureza interativa ou contexto argumentativo da conversa, bem como os fins pragmáticos sociais que essa versão foi projetada para alcançar. (ibid., p. 89).

Em seu arcabouço, o estudo do uso de informação não pode ser considerado em termos de um indivíduo isolado ou fora de um contexto específico. Em vez disso, deve se focar sobre o contexto social, interação e discurso por meio do qual o compartilhamento de informação ocorre.

Pettigrew $(1999 ; 2000)$ utilizou o uso informacional de Tuominen e Savolainen (1997) como estrutura de ação sócio discursiva para derivar sua noção de base informacional. Usando uma abordagem etnográfica, ela estudou o fluxo de Serviços de Informação Humanos $(\mathrm{SIH}){ }^{14}$ entre enfermeiras e idosos em clínicas de pés comunitária. A SIH foi definida como "um constructo comunicativo envolvendo a natureza ou disponibilidade de serviços e programas locais que é produzido em um contexto social baseado em comunidade" (PETTIGREW, 1999, p. 811). Está implícito nessa definição que o constructo comunicativo é dinâmico por natureza, ocorre entre e é construído por duas ou mais pessoas, podendo ser usado por indivíduos envolvidos em obter benefícios cognitivos, sociais, afetivos e instrumentais.

Usando essa definição, Pettigrew (1999) concluiu que o ambiente da clínica poderia ser melhor descrito como uma base informacional, ou seja, um "ambiente

\footnotetext{
${ }^{14}$ NT: Os autores usam originalmente a expressão: "human services information (HSI)".
} 
temporariamente criado pelo comportamento de pessoas que se juntam para desempenhar uma dada tarefa, mas a partir do qual emerge uma atmosfera social que alimenta o compartilhamento de informação espontâneo e casual” (ibid., p. 811). Ela explicou que a clínica de pés funcionava como uma base informacional porque a informação era compartilhada em múltiplas direções (por exemplo, alguém na clínica poderia fornecer ou obter $\mathrm{SIH}$ ) e porque $\mathrm{o} \mathrm{SIH}$ era compartilhado tanto propositalmente quanto casualmente. Pettigrew sugeriu que sua estrutura de base informacional pode ser usada para o estudo do fluxo informal de informação em outros arranjos comunitários, incluindo salões de beleza, playgrounds onde pais interagem enquanto suas crianças brincam, reuniões de grupos de interesses especiais e outras clínicas de saúde.

Uma ideia predominante que rendeu fundamentos para o estudo de aspectos sociais do comportamento informacional é a teoria de rede social. Williamson (1998) usou uma abordagem de rede social para derivar seu modelo de aquisição informacional casual. Proveniente do estudo do comportamento informacional diário de idosos australianos, seu modelo descreve como as pessoas obtêm informação, tanto acidentalmente como propositalmente, mediante suas redes íntimas e pessoais (família, amigos), redes pessoais mais amplas (clubes, igrejas, organizações de voluntariado) e as mídias de massa (jornais, televisão, rádio, revistas). Sua análise considera o estilo de vida dos indivíduos, valores, circunstâncias socioeconômicas, ambiente físico e características pessoais.

No contexto do serviço público brasileiro, analogamente a Sousa (1997), Cruz (2013) destaca que a tomada de decisão frequentemente é fundamentada em experiências pessoais, quando não são encontrados recursos informacionais que atendam à demanda:

Com base na análise das causas e impactos relativos aos problemas ligados à informação, se pode notar que estratégias de contorno surgem como consequência de problemas ligados à ausência ou baixa qualidade da informação. Dessa forma, quando as necessidades de informação dos participantes do processo de construção do plano estratégico não eram satisfeitas, como consequência da falta de informações, da falta de sistematização de informações e dados, da geração de informações deficientes (baixa qualidade), da grande quantidade de informações repetidas, os usuários da informação utilizam estratégias alternativas para a tomada de decisão, que envolviam, especialmente, a fundamentação das escolhas em experiências pessoais de ordem prática (empirismo). [...] (CRUZ, 2013, p. 227). 
Segundo Sonnenwald (1999), dentro de um contexto há um horizonte de informação no qual uma pessoa age. A autora sugere que uma pessoa, ao decidir buscar uma informação, é orientada por um horizonte de informação no qual ela age para procurar informações. Este horizonte de informação pode ser constituído por uma variedade de recursos de informação, tais como: a) redes sociais formadas por colegas, especialistas em assuntos, professores; b) documentos, incluindo legislação, páginas da web, livros; c) e, ainda, pode se dar a partir da sua própria experiência e observação no mundo. Para esta autora, o horizonte de informação com seus recursos de informação associados, é determinado social e individualmente pelas situações e contextos sociais, culturais, econômicos e tecnológicos em que a pessoa se encontra.

Por vezes, o desafio é entender esse horizonte pode ser expandido para incluir recursos de informação apropriados às demandas informacionais de uma pessoa. Opiniões que os colegas de alguém consideram sobre o valor de um recurso particular influenciarão as próprias opiniões sobre o valor desse recurso (SONNENWALD; WILDEMUTH; HARMON, 2001). Ou seja, o horizonte de informação se refere aos recursos que um indivíduo precisa recorrer ao se confrontar com um problema que requer o uso de informações.

Nesse sentido, fica evidente que o comportamento informacional dos usuários de um sistema é diretamente influenciado pelo contexto social em que se encontram. As normas sociais, explícitas ou implícitas, são motivadores para buscar ou evitar as informações, como também interferem no compartilhamento das informações (ou na precariedade deste). Sendo esses usuários ao mesmo tempo produtores e utilizadores da informação, seu comportamento e o contexto em que estão inseridos são elementos que atuam efetivamente no ciclo da gestão da informação em uma organização, constituindo-se, assim, importantes focos de observação dentro desse processo. 


\section{O IBAMA NO CONTEXTO DO SERVIÇO PÚBLICO BRASILEIRO}

Autarquia federal vinculada ao Ministério do Meio Ambiente, o Ibama tem como atividades finalísticas o licenciamento ambiental, fiscalização e controle da qualidade ambiental e do uso dos recursos naturais, executando as ações de competência federal com o objetivo de assegurar o desenvolvimento sustentável do país ${ }^{15}$. Tais atividades vão ao encontro do pensamento de Serres (1991), que aponta a necessi-

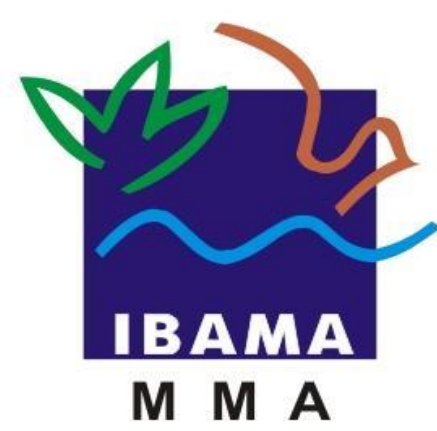

Figura 3 - Marca do lbama. dade premente da humanidade ter "controle sobre o controle" que exerce sobre a natureza, tendo em vista que as mudanças climáticas e ambientais provocadas pela ação do homem podem tornar o planeta inabitável para a própria raça humana, extinguindo-a da mesma forma como já o fez com várias outras espécies. Isso não significa deixar de atuar sobre a natureza, mas sim agir com responsabilidade e de maneira sustentável, ou seja, garantindo que não haja esgotamento dos recursos naturais, como também controlando os resíduos produzidos por suas atividades. $\mathrm{O}$ que Serres propõe, portanto, é que a relação do homem com o resto do mundo deve ser revisada e que seja "assinando" um contrato com a natureza com vistas a reestabelecer o equilíbrio: "A Terra, na verdade, nos fala em termos de forças, de ligações e de interações, o que basta para fazer um contrato. Cada um dos parceiros em simbiose deve, de direito, a vida ao outro, sob pena de morte" (1991, p. 52).

Tais preocupações se refletem também nas ideias de Santos (1994), que aponta o homem como um fator geológico, à medida em que altera o espaço geográfico e interfere nos ciclos naturais, sendo por vezes mais devastador que qualquer cataclismo natural, uma vez que este constitui um incidente momentâneo, enquanto a ação antrópica tem efeitos continuados. Cabe aí destacar os problemas da globalização sob a ótica capitalista, que busca "compartilhar" os recursos naturais passíveis de exploração e os mercados consumidores, mas esquece de compartilhar, na mesma medida, a riqueza gerada e os problemas locais - fome, miséria, falta de acesso à educação, saneamento e assistência básica de saúde, dentre tantos outros.

\footnotetext{
${ }^{15}$ Fonte: http://ibama.gov.br/institucional/sobre-o-ibama/sobre-o-ibama-identidade-organizacional. Acesso em 19.jan.2018.
} 
Períodos prolongados de estiagem ou enchentes e poluição das águas e do solo, por exemplo, comprometem a segurança alimentar e ampliam as epidemias. Fatalmente, as populações que menos usufruem dos benefícios dos mercados globalizados são aquelas que sofrem seus efeitos de forma mais violenta.

Nesse sentido, setores produtivos com forte poder econômico e grupos políticos conservadores - naturalmente vinculados àqueles que detêm o poder econômico vêm questionando e combatendo intensamente os resultados das pesquisas sobre mudanças climáticas e outros impactos das ações humanas sobre o planeta. Longe de qualquer embasamento científico, as argumentações se baseiam em fatores puramente econômicos, sob a alegação de que é necessário produzir para superar a pobreza mundial - muito embora a riqueza produzida permaneça sob domínio de grupos reduzidos. Ora, se há trinta anos havia dúvidas entre a comunidade científica sobre as mudanças climáticas ocasionadas pela ação do homem, atualmente a discussão se restringe a qual impacto tais mudanças podem acarretar sobre a qualidade de vida humana e em quanto tempo se tornarão irreversíveis. $O$ discurso que desconsidera totalmente as evidências científicas torna-se ainda mais perigoso quando os interlocutores adotam posturas fechadas ao diálogo e ignoram, inclusive, os efeitos econômicos decorrentes das alterações no clima do planeta ${ }^{16}$.

Por outro lado, observa-se, nas últimas décadas, o aumento da consciência ecológica e da preocupação com a sustentabilidade entre a população, o que implica tanto em maior apoio, quanto em mais cobrança às ações do Ibama e dos órgãos ambientais em geral.

\subsection{BREVE HISTÓRICO}

A partir da década de 1970, quando aconteceu a primeira conferência da Organização das Nações Unidas (ONU) com a temática ambiental, em Estocolmo, Suécia, em 1972, via-se uma crescente preocupação com o excesso de poluição e o uso desmedido dos recursos naturais. A criação do Ibama, em 1989, foi resultado da pressão da sociedade brasileira e internacional para que o Brasil passasse a gerir seu

\footnotetext{
${ }^{16}$ Sobre o assunto, ver: "Trump sobre relatório climático do seu Governo: 'Não acredito"', disponível em: <https://brasil.elpais.com/brasil/2018/11/27/internacional/1543283242_634443.html>. Acesso em 29.nov.2018.
} 
patrimônio ambiental de forma integrada, de modo a reduzir o impacto de grandes obras e controlar desmatamentos, caça e pesca predatória.

Assim, o Ibama foi criado pela Lei no 7.735, de 22 de fevereiro de 1989, com a finalidade de coordenar e executar a Política Nacional de Meio Ambiente (PNMA). A essa época, era o único órgão federal com atuação nessa área, tendo sido originado da junção de quatro órgãos: a Secretaria do Meio Ambiente (Sema), Superintendência da Borracha (Sudhevea), Superintendência de Desenvolvimento da Pesca (Sudepe) e Instituto Brasileiro de Desenvolvimento Florestal (IBDF). Com exceção da Sema que era vinculada ao Ministério do Interior e não possuía unidades fora do Distrito Federal - os demais órgãos que deram origem ao lbama tinham como finalidade dar incentivos fiscais e fomentar o desenvolvimento econômico, sendo a preservação ambiental um tema muito reduzido em suas estruturas. Sobre isso, o site do lbama relata $^{17}$ :

No início, o lbama precisou ser consolidado. A visão distinta de quatro órgãos em apenas um gerava muitos conflitos internos, uma vez que havia vários grupos com diferentes agendas. Primeiro, o novo instituto teve que criar uma percepção de unidade. O primeiro passo foi a abertura do Ibama à imprensa e sua atuação junto à mídia. Muito devido à relação entre o instituto e os meios de comunicação, a sociedade passa a receber em casa a temática ambiental de conservação e desenvolvimento sustentável.

Ao longo dos anos, o lbama consolidou-se como uma referência na área ambiental, tendo uma das marcas mais lembradas pela população quando se fala em meio ambiente, o que lhe rendeu o prêmio Top of Mind da Folha de São Paulo ${ }^{18}$ em 2007 - primeiro ano em que a categoria ambiental foi incluída na pesquisa sobre lembrança espontânea de marcas - sem que tenha investido qualquer recurso financeiro em publicidade.

No mesmo ano de 2007, por força da Medida Provisória n 366/2007, o lbama foi literalmente dividido, tendo suas competências e estrutura (física, administrativa e de recursos humanos) repartidas com o Instituto Chico Mendes de Conservação da Biodiversidade (ICMBio), que veio a efetivar-se com a aprovação da MP 366 no Legislativo - a despeito de toda a movimentação contrária por parte dos servidores e

\footnotetext{
17 Fonte: http://ibama.gov.br/institucional/sobre-o-ibama. Acesso em 19.jan.2018.

18 Fonte: http://www1.folha.uol.com.br/folha/especial/2007/topofmind/tm2910200703.shtml. Acesso em 20.maio.2018.
} 
da reduzida bancada ambientalista da Câmara dos Deputados - publicando-se então a Lei no 11.516, de 28 de agosto de 2007.

A partir daí o ICMBio passou a ser responsável pela gestão das unidades de conservação federais e pelos centros de pesquisa voltados à preservação da biodiversidade, ficando assim definidas as finalidades do lbama, expressas no Art. $2^{\circ}$ da Lei no 7.735/1989, alterada pela Lei № 11.516/2007:

I - exercer o poder de polícia ambiental;

II - executar ações das políticas nacionais de meio ambiente, referentes às atribuições federais, relativas ao licenciamento ambiental, ao controle da qualidade ambiental, à autorização de uso dos recursos naturais e à fiscalização, monitoramento e controle ambiental, observadas as diretrizes emanadas do Ministério do Meio Ambiente; e

III - executar as ações supletivas de competência da União, de conformidade com a legislação ambiental vigente.

Anteriormente, já havia se iniciado o processo de descentralização da gestão ambiental, com a edição da Lei no 11.284, de 2 de março de 2006, que instituiu o Serviço Florestal Brasileiro (SFB) e transferiu para os estados e municípios a responsabilidade de controlar a produção e uso dos recursos florestais em sua área de jurisdição. Na prática, isso significa que tais atribuições - primordialmente sob o encargo do IBDF e, posteriormente, do lbama - passaram para o controle dos entes federativos. O lbama, no entanto, manteve as atividades de fiscalização de forma supletiva, sobretudo em temas de interesse nacional, como o desmatamento na Amazônia Legal.

A questão da descentralização da gestão ambiental já era prevista na Política Nacional de Meio Ambiente, de 1981, que instituiu o Sistema Nacional do Meio Ambiente (Sisnama), constituído pelos "órgãos e entidades da União, dos Estados, do Distrito Federal, dos Territórios e dos Municípios, bem como as fundações instituídas pelo Poder Público, responsáveis pela proteção e melhoria da qualidade ambiental" (art. 6º da Lei no 6.938/1981). A ideia do Sisnama é que cada esfera administrativa do Poder Executivo assuma a responsabilidade pela conservação do meio ambiente no limite de sua competência, trabalhando em cooperação para o alcance desses objetivos.

Esse processo veio a se consolidar com a publicação, em dezembro de 2011, da Lei Complementar ㄲo 140, a qual definiu com mais clareza as competências das esferas federal, estadual e municipal, determinando, inclusive, a prevalência da 
autoridade licenciadora nas ações de fiscalização ambiental. Assim, a gestão da fauna silvestre, por exemplo, passa a ser prioritariamente dever do ente federado, sendo que o Ibama continua atuando em ações de combate ao tráfico de animais. De acordo com a LC 140, são de responsabilidade da União, para fins de licenciamento e fiscalização, as áreas e atividades:

a) localizados ou desenvolvidos conjuntamente no Brasil e em país limítrofe;

b) localizados ou desenvolvidos no mar territorial, na plataforma continental ou na zona econômica exclusiva;

c) localizados ou desenvolvidos em terras indígenas;

d) localizados ou desenvolvidos em unidades de conservação instituídas pela União, exceto em Áreas de Proteção Ambiental (APAs);

e) localizados ou desenvolvidos em 2 (dois) ou mais Estados;

f) de caráter militar, excetuando-se do licenciamento ambiental, nos termos de ato do Poder Executivo, aqueles previstos no preparo e emprego das Forças Armadas, conforme disposto na Lei Complementar no 97, de 9 de junho de 1999;

g) destinados a pesquisar, lavrar, produzir, beneficiar, transportar, armazenar e dispor material radioativo, em qualquer estágio, ou que utilizem energia nuclear em qualquer de suas formas e aplicações, mediante parecer da Comissão Nacional de Energia Nuclear (Cnen); ou

h) que atendam tipologia estabelecida por ato do Poder Executivo, a partir de proposição da Comissão Tripartite Nacional, assegurada a participação de um membro do Conselho Nacional do Meio Ambiente (Conama), e considerados os critérios de porte, potencial poluidor e natureza da atividade ou empreendimento. (art. $7^{\circ}$, XIV, da LC $n^{\circ}$ 140/2011).

Afora as discussões sobre a limitação do trabalho do lbama e a possibilidade de maior interferência política nos órgãos ambientais estaduais - que fogem aos objetivos deste trabalho - observa-se que a atuação do lbama tem se tornado mais restrita, mas também mais especializada ao longo dos anos. Isso exige uma readaptação da instituição para um trabalho com um nível maior de gestão e planejamento, como também a capacitação dos servidores para assumir novas atribuições.

Além disso, nos últimos anos, o lbama tem enfrentado sérios ataques criminosos durante as atividades de campo ${ }^{19}$, sobretudo na região Norte, onde a economia depende, em boa parte, de atividades ilícitas, tais como o desmatamento,

19 Fonte: http://www.ibama.gov.br/noticias/436-2018/1756-criminosos-sao-detidos-apos-ataque-aequipe-do-ibama-em-buritis-ro e https://g1.globo.com/jornal-nacional/noticia/2018/10/23/equipes-doibama-sofrem-ataques-durante-fiscalizacao-na-amazonia.ghtml . Acesso em 01.jan.2019. 
a invasão de terras indígenas e de unidades de conservação para expansão agrícola e pecuária e a mineração ilegal. A fim de garantir a segurança do patrimônio e, sobretudo, de suas equipes, o lbama vem priorizando atividades de inteligência ${ }^{20}$ para o combate aos crimes ambientais, de modo a aumentar a efetividade das operações e reduzir o tempo de atuação em campo.

A partir desse breve histórico, depreende-se que o Instituto possui um corpo técnico com larga experiência na área ambiental, em sua maioria com mais de trinta anos de atuação no Serviço Público. Entretanto, ao mesmo tempo em que essa experiência significa um grande conhecimento acumulado, alerta também para a fragilidade na gestão desse conhecimento, agravada pelas aposentadorias recentes ou iminentes dos servidores mais antigos.

Nesse contexto, destaca-se que a alta administração do lbama já identificou a necessidade de desenvolver no Instituto ações de gestão da informação, tanto que registrou em seu Plano Estratégico para o período de 2016 a 2019 os seguintes objetivos estratégicos:

OE 7: Prover dados e informações ambientais: Qualificar os dados e gerar valor na informação disponibilizada à sociedade, assim como fortalecer a avaliação e o monitoramento integrado da qualidade ambiental;

$[\ldots]$

OE 13: Aprimorar a gestão da informação e do conhecimento: Desenvolver e/ou melhorar os sistemas existentes visando à efetiva sistematização e integração dos dados ambientais e sua disponibilização tanto para subsídio de gestão e tomada de decisão pelas entidades do SISNAMA quanto para a sociedade, visando à prestação de serviços de qualidade aos usuários, a garantia da qualidade ambiental e a proteção do meio ambiente, assegurando 0 desenvolvimento sustentável. (IBAMA, 2016, p. 6-8).

Tal preocupação foi também registrada no Mapa Estratégico apresentado na

Figura 4, no que concerne aos Resultados Institucionais e aos Processos Internos.

20 O termo "inteligência" é aqui utilizado no sentido em que é empregado na literatura militar: "[...] $\mathrm{Na}$ literatura militar a inteligência (intelligence) resulta da busca de informações relevantes sobre o ambiente estrangeiro e o adversário. Obtém-se a partir da coleta, processamento, integração, análise, avaliação, e interpretação da informação disponível." (TARAPANOFF, 2007, p. 212-213). No Ibama, as atividades de inteligência vinculam-se estritamente ao trabalho da Fiscalização Ambiental. 
Figura 4 - Mapa estratégico do Ibama para o período de 2016 a 2019.

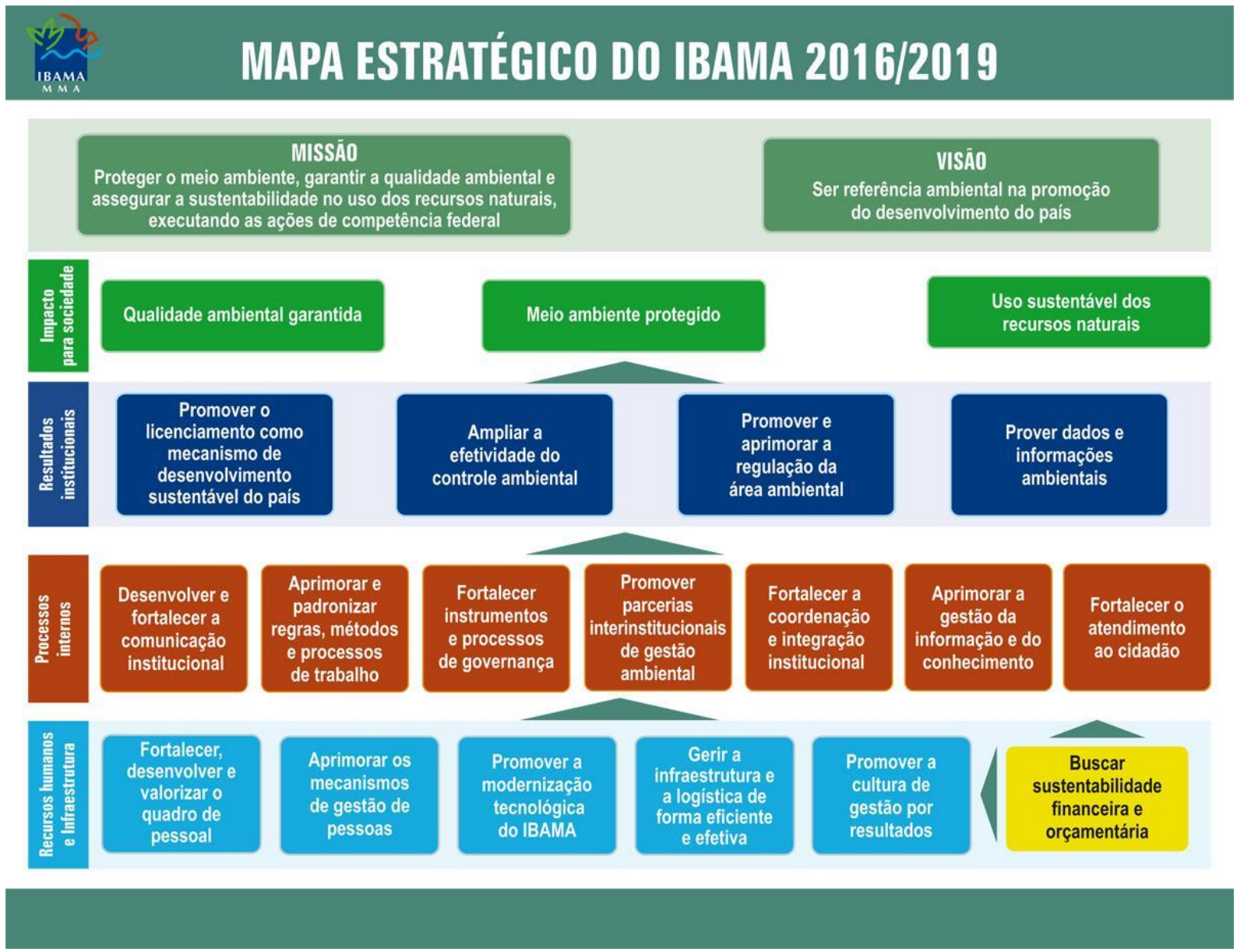

Fonte: http://www.ibama.gov.br/images/institucional/mapa_estrategico_ibama_2016-2019.jpg, acesso em 19.jan.2018

Como bem colocado por Bem, Prado e Delfino (2013), a gestão da informação e do conhecimento na administração pública depara-se com complexas questões culturais, arraigadas em decorrência de fatores burocráticos. Entretanto, não se pode perder de vista os princípios básicos que devem reger o serviço público: a legalidade, a impessoalidade, a moralidade, a publicidade e a eficiência.

\subsection{ESTRUTURA CENTRAL E UNIDADES DESCENTRALIZADAS}

Conforme estabelece o Decreto № 8.973/2017, que traz, em seu Anexo I, a Estrutura Regimental do Ibama, assim está definida a sua estrutura organizacional:

I - órgão colegiado: Conselho Gestor;

II - órgão de assistência direta e imediata ao Presidente: Gabinete;

III - órgãos seccionais: 
a) Procuradoria Federal Especializada;

b) Auditoria Interna;

c) Corregedoria; e

d) Diretoria de Planejamento, Administração e Logística;

IV - órgãos específicos singulares:

a) Diretoria de Qualidade Ambiental;

b) Diretoria de Licenciamento Ambiental;

c) Diretoria de Proteção Ambiental;

d) Diretoria de Uso Sustentável da Biodiversidade e Florestas; e

e) Centro Nacional de Monitoramento e Informações Ambientais; e V - órgãos descentralizados:

a) Superintendências;

b) Gerências Executivas; e

c) Unidades Técnicas.

Os órgãos listados nos incisos I a IV funcionam na sede do lbama em Brasília/DF. Em cada estado da Federação e no Distrito Federal funciona uma Superintendência, algumas das quais coordenam também Gerências Executivas e Unidades Técnicas (normalmente em estados com maior extensão territorial).

O Regimento Interno do Ibama (Portaria n- 14/2017) divide a estrutura administrativa das Superintendências em duas Divisões: de Administração e Finanças (Diafi) e Técnico-ambiental (Ditec). A organização dessas divisões em Núcleos, embora não legalmente instituídos, é necessária para organizar a distribuição das atividades e para a gestão documental. Espelhando basicamente a estrutura das Diretorias do Ibama-sede, a Superintendência em Pernambuco (Supes/PE) está estruturada como se apresenta no Quadro 1.

Quadro 1 - Estrutura organizacional da Superintendência do Ibama em Pernambuco

\begin{tabular}{|c|c|}
\hline Sigla & Setor \\
\hline SUPES-PE & $\begin{array}{l}\text { Superintendência do Ibama em Pernambuco (Gabinete do } \\
\text { Superintendente) }\end{array}$ \\
\hline NUCOM-PE & Núcleo de Comunicação Social \\
\hline NUIP-PE & $\begin{array}{l}\text { Núcleo Técnico Setorial Descentralizado de Instrução Processual de } \\
\text { Autos de Infração }\end{array}$ \\
\hline DIAFI-PE & Divisão de Administração e Finanças \\
\hline COAD-PE & $\begin{array}{l}\text { Núcleo de Comunicação Administrativa (protocolo, arquivo e } \\
\text { serviços gerais) }\end{array}$ \\
\hline NUCOMP-PE & Núcleo de Compras e Contratos \\
\hline NUMAP-PE & Núcleo de Material e Patrimônio \\
\hline NUCOFIN-PE & Núcleo de Orçamento, Contabilidade e Finanças \\
\hline
\end{tabular}




\begin{tabular}{|l|l|}
\hline NUARRE-PE & Núcleo de Arrecadação \\
\hline NUGEP-PE & Núcleo de Gestão de Pessoas \\
\hline NINFO-PE & Núcleo de Tecnologia da Informação \\
\hline DITEC-PE & Divisão Técnico-Ambiental \\
\hline NUBIO-PE & Núcleo de Biodiversidade e Florestas \\
\hline NLA-PE & Núcleo de Licenciamento Ambiental \\
\hline NUFIS-PE & Núcleo de Fiscalização Ambiental \\
\hline NUIN-PE & Núcleo de Inteligência \\
\hline NQA-PE & Núcleo de Qualidade Ambiental \\
\hline NUPAEM-PE & Núcleo de Prevenção e Atendimento às Emergências Ambientais \\
\hline PREVFOGO-PE & Núcleo de Prevenção e Combate aos Incêndios Florestais \\
\hline
\end{tabular}

Fonte: Elaboração própria, 2018.

As atividades finalísticas desenvolvidas no lbama/PE estão concentradas basicamente na Ditec e suas atribuições estão distribuídas como se lê no Quadro 2.

Quadro 2 - Atribuições dos setores finalísticos da Supes/PE

\begin{tabular}{|c|c|}
\hline Setor & Atribuições \\
\hline $\begin{array}{l}\text { Divisão Técnico-ambiental (Ditec- } \\
\text { PE) }\end{array}$ & $\begin{array}{l}\text { Coordenar as ações, programas, projetos e atividades } \\
\text { finalísticas da Supes/PE, relacionadas ao } \\
\text { licenciamento, à qualidade ambiental, ao acesso ao } \\
\text { uso dos recursos } \\
\text { Ambientais, fiscalização ambiental federal, bem como } \\
\text { em questões de acidentes e emergências ambientais. }\end{array}$ \\
\hline $\begin{array}{l}\text { Núcleo de Biodiversidade e } \\
\text { Florestas (Nubio-PE) }\end{array}$ & $\begin{array}{l}\text { Executar ações relativas ao controle e recuperação } \\
\text { ambiental de áreas degradadas, bem como ações } \\
\text { relacionadas ao controle dos recursos faunísticos e } \\
\text { pesqueiros. }\end{array}$ \\
\hline $\begin{array}{l}\text { Núcleo de Licenciamento } \\
\text { Ambiental (NLA-PE) }\end{array}$ & $\begin{array}{l}\text { Executar atividades relacionadas ao licenciamento } \\
\text { ambiental de atividades e empreendimentos efetiva } \\
\text { ou potencialmente poluidores, bem como daqueles } \\
\text { capazes de causar degradação ambiental, em } \\
\text { consonância com as orientações da Administração } \\
\text { Central. }\end{array}$ \\
\hline $\begin{array}{l}\text { Núcleo de Fiscalização Ambiental } \\
\text { (Nufis-PE) }\end{array}$ & Executar as ações de fiscalização ambiental. \\
\hline Núcleo de Inteligência (Nuin-PE) & $\begin{array}{l}\text { Investigação, apuração de denúncias e planejamento } \\
\text { de operações de fiscalização ambiental. }\end{array}$ \\
\hline $\begin{array}{l}\text { Núcleo de Qualidade Ambiental } \\
\text { (NQA-PE) }\end{array}$ & $\begin{array}{l}\text { Executar as ações pertinentes à implementação dos } \\
\text { Cadastros Técnicos Federais de Atividades e } \\
\text { Instrumentos de Defesa Ambiental e de Atividades } \\
\text { Potencialmente Poluidoras ou Utilizadoras dos } \\
\text { Recursos Ambientais. }\end{array}$ \\
\hline
\end{tabular}


Núcleo de Prevenção e Atendimento às Emergências Ambientais (Nupaem-PE)

Núcleo de Prevenção e Combate aos Incêndios Florestais (Prevfogo-PE)
Atua em casos de iminência ou após acidentes com impacto no meio ambiente, adotando medidas para prevenção ou reparação de danos ambientais.

Coordenar as brigadas contra incêndio florestal que atuam no estado, em áreas de proteção ambiental de responsabilidade da União.

Fonte: Elaboração própria (2019), baseada no Regimento Interno do Ibama

(Portaria Ibama № 14/2017).

\subsection{GESTÃO DOCUMENTAL NO IBAMA}

Tal como vários outros órgãos da Administração Pública Federal, o Ibama adotou o Sistema Eletrônico de Informações (SEI) em 2017. Com esse sistema, os processos passaram a ser produzidos e tramitados em formato exclusivamente digital, sendo que os processos físicos ainda em tramitação foram digitalizados e migrados para o novo sistema.

Antes disso, o lbama fez uso de vários sistemas de gestão documental (SisProt, SisWeb, SisWeb2), que se limitavam a registrar a tramitação e os metadados básicos dos documentos e processos que eram protocolados na instituição. Já em 2013, na tentativa de modernizar a gestão documental dentro do Instituto, foi implantado o Sistema Informatizado de Gestão Documental (Doc.Ibama), que, diferentemente dos sistemas anteriores, trouxe uma inovação significativa para o modelo existente, passando a produção e expedição dos documentos a serem executados diretamente dentro do sistema, como também o cadastramento, a tramitação e o arquivamento de expedientes e processos. Outra mudança expressiva foi a digitalização de todos os processos em andamento no lbama, possibilitando a consulta e visualização do conteúdo em qualquer unidade do Instituto no país. No entanto, nesse primeiro momento, não houve a substituição do processo físico pelo processo eletrônico. 0 sistema de gestão documental, então, passou a funcionar de forma híbrida, compreendendo a massa documental analógica e sua correspondente em formato digital.

Embora inegável o avanço do sistema implantado, o Doc.lbama apresentava diversas dificuldades em sua operação: excesso de ações necessárias para produção de documentos; tramitação mais complexa (documento físico e digital tramitando paralelamente); dificuldade no resgate de informações por meio das consultas disponíveis; usabilidade precária; entre tantas outras. Diante desse cenário, e com a 
oferta de adesão gratuita ao $\mathrm{SEl}$, através de convênio com o Ministério do Planejamento, o lbama optou pela substituição do sistema de gestão documental, passando a operar exclusivamente com o SEI desde maio de 2017.

Por sua vez, o SEI possibilita que a produção, edição, assinatura digital e trâmite de documentos sejam feitos diretamente no sistema. Além disso, ele permite que um mesmo processo tramite em várias unidades ao mesmo tempo, reduzindo significativamente o tempo de movimentação de um processo, uma vez que vários setores podem operá-lo simultaneamente. Ademais, a visualização integral dos autos está disponível a qualquer tempo para todas as unidades, desde que não tenha algum atributo de restrição legal de informação (documentos sigilosos).

No entanto, cabe destacar que nas mudanças dos sistemas Sisweb para o Doc.lbama, como também deste para o SEI, não houve migração dos dados do sistema anterior - por questões técnicas e de custo operacional - o que implicou na migração manual (digitalização e inserção de metadados) de todos os processos em tramitação dentro do lbama. Além do retardo na tramitação dos processos durante os meses de transição, esse fato resultou também no agravamento do "esquecimento" da massa documental já arquivada, visto que para consultá-la é necessário ainda acessar os sistemas anteriores e os documentos em meio físico.

Superada a fase de transição, o SEI representa não só um grande avanço, mas também uma substancial mudança na forma de operação e tramitação dos documentos. De acordo com a página que fala sobre o SEI na intranet do Ibama ${ }^{21}$, o sistema traz os seguintes benefícios:

a. Portabilidade $-100 \%$ Web e pode ser acessado por meio dos principais navegadores do mercado: Internet Explorer, Firefox e Google Chrome.

b. Acesso remoto - Em razão da portabilidade já mencionada, pode ser acessado remotamente por diversos tipos de equipamentos, como microcomputadores, notebooks, tablets e smartphones de vários sistemas operacionais (Windows, Linux, IOS da Apple e Android do Google).

c. Acesso de usuários externos - Gerencia o acesso de usuários externos aos expedientes administrativos que Ihes digam respeito, permitindo que tomem conhecimento do teor do processo e, por exemplo, assinem remotamente contratos e outros tipos de documentos.

\footnotetext{
${ }^{21}$ Fonte: https://ibamanet.ibama.gov.br/index.php?option=com_content\&view=article\&id=2991:sei-no-
} ibama\&catid=65:sei-modulo\&ltemid=277. Acesso em 19.jan.2018. 
d. Controle de nível de acesso - Gerencia a criação e o trâmite de processos e documentos restritos e sigilosos, conferindo o acesso somente às unidades envolvidas ou a usuários específicos.

e. Tramitação em múltiplas unidades - Incorpora novo conceito de processo eletrônico, que rompe com a tradicional tramitação linear, inerente à limitação física do papel. Deste modo, várias unidades podem ser demandadas simultaneamente a tomar providências e manifestar-se no mesmo expediente administrativo, sempre que os atos sejam autônomos entre si.

f. Funcionalidades específicas - Controle de prazos, ouvidoria, estatísticas da unidade, tempo do processo, base de conhecimento, pesquisa em todo teor, acompanhamento especial, modelos de documentos, textos padrão, sobrestamento de processos, assinatura em bloco, organização de processos em bloco, acesso externo, entre outros.

g. Agilidade - O sistema reduz o tempo de realização das atividades por permitir a atuação simultânea de várias unidades em um mesmo processo, ainda que distantes fisicamente, além disso eliminará os trâmites em níveis hierárquicos desnecessários.

h. Papel zero - O SEl-Ibama, por ser totalmente online, reduz o uso de papel em documentos e processos visto que a produção interna torna-se exclusivamente eletrônica.

i. Otimização do contato com outras entidades - O sistema já está implantado em diversos órgãos da Administração Pública, o que torna menos burocrática a recepção e o envio eletrônico de documentos a atores externos.

j. Sistema intuitivo - O sistema é intuitivo, estruturado e com boa navegabilidade e usabilidade, além disso é acessível aos principais navegadores disponíveis.

Este último tópico, entretanto, requer um certo questionamento, pois embora o SEI tenha de fato uma interface bastante simples, ele exige algum tempo para que o usuário se acostume com a interface, pois possui ícones pouco convencionais e navegação não muito intuitiva, tendo sua usabilidade prejudicada. Além disso, a pesquisa disponível no sistema mostra-se bastante limitada e de difícil operação, deixando muito a desejar quanto à funcionalidade de recuperação da informação.

Também a questão da dependência absoluta de uma conexão com a internet para seu funcionamento - não só no caso do SEI, como de todos os demais sistemas - torna-se um complicador diante da fragilidade e baixa qualidade da estrutura de rede disponível nos órgãos públicos. Isso significa que, no caso de uma queda ou mesmo lentidão na conexão, todas as atividades da instituição restam paralisadas. 


\subsection{PROCESSOS DE TRABALHO E SISTEMAS DE INFORMAÇÃO}

Os processos administrativos que registram as atividades finalísticas desenvolvidas na Superintendência do Ibama em Pernambuco estão sinteticamente descritos no Quadro 3:

Quadro 3 - Processos de trabalho das atividades-fim da Supes/PE.

\begin{tabular}{|c|c|c|c|}
\hline Setor & $\begin{array}{l}\text { Tipo de } \\
\text { processo }\end{array}$ & Origem & Observações \\
\hline $\begin{array}{l}\text { Divisão } \\
\text { Técnico- } \\
\text { ambiental } \\
\text { (Ditec) }\end{array}$ & $\begin{array}{l}\text { Assessoramento/ } \\
\text { manifestação } \\
\text { técnica }\end{array}$ & $\begin{array}{l}\text { - Demanda externa } \\
\text { (Ministério Público; } \\
\text { Poder Judiciário); } \\
\text { - Solicitação } \\
\text { interna } \\
\text { (Superintendente; } \\
\text { Diretorias em } \\
\text { Brasília). }\end{array}$ & $\begin{array}{l}\text { A Ditec reúne todos os núcleos } \\
\text { da área-fim e, por isso, } \\
\text { eventualmente pode pronunciar- } \\
\text { se em qualquer processo dos } \\
\text { núcleos a ela vinculados. }\end{array}$ \\
\hline $\begin{array}{l}\text { Núcleo de } \\
\text { Licenciamento } \\
\text { Ambiental (NLA) }\end{array}$ & $\begin{array}{l}\text { Licenciamento } \\
\text { ambiental }\end{array}$ & $\begin{array}{l}\text { - Por solicitação do } \\
\text { interessado } \\
\text { (empreendedor). }\end{array}$ & $\begin{array}{l}\text { - Todos os processos de } \\
\text { licenciamento do lbama iniciam } \\
\text { na Diretoria de Licenciamento } \\
\text { (Dilic), em Brasília, que distribui } \\
\text { entre as suas coordenações ou } \\
\text { Núcleos nos estados. } \\
\text { - Esses processos raramente } \\
\text { tramitam, mas vão crescendo ao } \\
\text { longo do tempo, com os } \\
\text { documentos do empreendedor e } \\
\text { do lbama. } \\
\text { - Compreendem desde o pedido, } \\
\text { a emissão de autorizações ou } \\
\text { Licença Prévia (LP), Licença de } \\
\text { Instalação (LI) e Licença de } \\
\text { Operação (LO), até o } \\
\text { acompanhamento do } \\
\text { cumprimento das condicionantes } \\
\text { das licenças emitidas. }\end{array}$ \\
\hline $\begin{array}{l}\text { Núcleo de } \\
\text { Fiscalização } \\
\text { Ambiental } \\
\text { (Nufis) }\end{array}$ & $\begin{array}{l}\text { Apuração de } \\
\text { infraç̃̃es } \\
\text { ambientais }\end{array}$ & $\begin{array}{l}\text { Gerados a partir do } \\
\text { trabalho de } \\
\text { fiscalização: } \\
\text { - Operações de } \\
\text { rotina; } \\
\text { - Atividade de } \\
\text { inteligência } \\
\text { (investigação); } \\
\text { - Denúncias (de } \\
\text { particulares ou } \\
\text { instituições). }\end{array}$ & $\begin{array}{l}\text { Os processos oriundos da } \\
\text { Fiscalização seguem um trâmite } \\
\text { de julgamento administrativo, } \\
\text { para posterior cobrança do } \\
\text { débito (multa) e/ou recuperação } \\
\text { do dano. }\end{array}$ \\
\hline
\end{tabular}




\begin{tabular}{|c|c|c|c|}
\hline \multirow[t]{3}{*}{$\begin{array}{l}\text { Núcleo de } \\
\text { Biodiversidade } \\
\text { e Florestas } \\
\text { (Nubio) }\end{array}$} & $\begin{array}{l}\text { Flora: } \\
\text { recuperação de } \\
\text { danos } \\
\text { ambientais }\end{array}$ & $\begin{array}{l}\text { - Decorrentes das } \\
\text { ações de } \\
\text { fiscalização (áreas } \\
\text { degradadas). }\end{array}$ & \multirow{2}{*}{$\begin{array}{l}\text { A gestão da fauna e da flora } \\
\text { nativas é atualmente } \\
\text { competência da Agência } \\
\text { Estadual de Meio Ambiente } \\
\text { (CPRH). Por essa razão, a } \\
\text { grande maioria dos processos } \\
\text { desse núcleo decorre de } \\
\text { desdobramentos das ações de } \\
\text { fiscalização (recuperação de } \\
\text { danos) ou do passivo ainda } \\
\text { existente (antigos termos de } \\
\text { guarda doméstica). }\end{array}$} \\
\hline & $\begin{array}{l}\text { Fauna: } \\
\text { regularização de } \\
\text { guarda } \\
\text { doméstica ou } \\
\text { criadouro de } \\
\text { animais } \\
\text { silvestres }\end{array}$ & $\begin{array}{l}\text { - São processos } \\
\text { antigos, que ainda } \\
\text { requerem alguma } \\
\text { ação para sua } \\
\text { finalização. }\end{array}$ & \\
\hline & $\begin{array}{l}\text { Pesca: } \\
\text { autorização de } \\
\text { transporte de } \\
\text { peixes } \\
\text { ornamentais }\end{array}$ & $\begin{array}{l}\text { - Por solicitação do } \\
\text { interessado. }\end{array}$ & \\
\hline $\begin{array}{l}\text { Núcleo de } \\
\text { Qualidade } \\
\text { Ambiental } \\
\text { (NQA) }\end{array}$ & $\begin{array}{l}\text { Análise de } \\
\text { alteração de } \\
\text { porte ou } \\
\text { atividade }\end{array}$ & $\begin{array}{l}\text { - Por solicitação do } \\
\text { interessado; } \\
\text { - De ofício, } \\
\text { decorrente de } \\
\text { ações de } \\
\text { fiscalização ou } \\
\text { auditoria no } \\
\text { sistema. }\end{array}$ & $\begin{array}{l}\text { - Referem-se aos registros do } \\
\text { Cadastro Técnico Federal de } \\
\text { Atividades Potencialmente } \\
\text { Poluidoras ou Utilizadoras de } \\
\text { Recursos Ambientais (CTF). } \\
\text { - Os registros no CTF são } \\
\text { autodeclaratórios, por isso } \\
\text { passam por auditorias para } \\
\text { verificação de inconsistências. } \\
\text { - Do CTF depende a cobrança da } \\
\text { Taxa de Controle e Fiscalização } \\
\text { Ambiental (TCFA), que varia } \\
\text { conforme porte e atividade da } \\
\text { empresa cadastrada. }\end{array}$ \\
\hline $\begin{array}{l}\text { Núcleo de } \\
\text { Prevenção e } \\
\text { Atendimento às } \\
\text { Emergências } \\
\text { Ambientais } \\
\text { (Nupaem-PE) }\end{array}$ & $\begin{array}{l}\text { Registro das } \\
\text { ocorrências das } \\
\text { emergências } \\
\text { atendidas }\end{array}$ & $\begin{array}{l}\text { - Denúncias ou } \\
\text { solicitações de } \\
\text { terceiros; } \\
\text { - Alertas de outros } \\
\text { órgãos públicos. }\end{array}$ & \\
\hline $\begin{array}{l}\text { Núcleo de } \\
\text { Prevenção e } \\
\text { Combate aos } \\
\text { Incêndios } \\
\text { Florestais } \\
\text { (Prevfogo) }\end{array}$ & $\begin{array}{l}\text { Contratação de } \\
\text { brigadistas }\end{array}$ & $\begin{array}{l}\text { - Edital de } \\
\text { contratação de } \\
\text { brigadistas. }\end{array}$ & \\
\hline
\end{tabular}

Fonte: Elaboração própria, 2019.

As atividades do Núcleo de Inteligência, por sua natureza sigilosa, raramente são registradas em processos administrativos. O mais comum é que os resultados das investigações passem a integrar os processos de Autos de Infração somente após a 
realização das operações de fiscalização decorrentes de tais atividades, a fim de subsidiar o julgamento das infrações identificadas.

Dentre todos os processos finalísticos que tramitam nas Superintendências, os que têm a tramitação mais complexa e que envolvem mais setores são os processos de apuração de infrações ambientais, que se iniciam no Núcleo de Fiscalização, após lavratura dos chamados "termos próprios", os quais devem ser julgados administrativamente para confirmação das sanções aplicadas na ação fiscalizatória: notificação, multa, advertência, apreensão, embargo, interdição - variáveis conforme a natureza da infração ambiental. Um diagrama do fluxo de tramitação dos processos de Autos de Infração pode ser visualizado no Apêndice $\mathbf{A}$.

Todos os processos administrativos são atualmente registrados no SEl. Além deste, o Ibama trabalha com diversos outros sistemas, relacionados no Anexo A. Entre eles, o Sistema Integrado de Arrecadação, Fiscalização e Cadastro (Sicafi), que reúne diversas atividades, tanto da área meio quanto das áreas fim. Esse sistema foi desenvolvido inicialmente somente com o módulo de Arrecadação e aos poucos foi ganhando novos módulos, a fim de integrar todas as atividades que implicam na cobrança de taxas ou multas aplicadas pelos Ibama, além de vincular todos os serviços prestados pelo Instituto. Por ser um dos sistemas mais antigos e que abarca uma grande base de dados, é também um dos mais complexos no que se refere à manutenção ou alteração de suas funcionalidades, pois qualquer intervenção frequentemente afeta diversos outros pontos do sistema.

Depois do SEI - que, por sua própria natureza, é utilizado por todos os setores do Ibama - o Sicafi é o sistema mais complexo e que abrange uma maior quantidade de atividades e setores. Sendo, portanto os dois sistemas que mais armazenam informações no âmbito do Instituto, estes servirão de base para a coleta e análise de dados deste estudo de caso. 


\section{METODOLOGIA}

Esta seção descreve os procedimentos metodológicos utilizados para a coleta dos dados e análise dos resultados.

\subsection{CARACTERIZAÇÃO DA PESQUISA}

A pesquisa ora apresentada caracteriza-se como uma pesquisa aplicada, uma vez que, de acordo com os conceitos apresentados por Laville e Dionne (1999), busca resolver problemas encontrados no ambiente real do estudo. Segundo seus objetivos, a pesquisa caracteriza-se também como descritiva, visto que efetua o levantamento das características do objeto e observa-o sistematicamente, relacionando aos conceitos estudados.

Quanto aos meios, este trabalho ampara-se na pesquisa documental e utiliza como método o estudo de caso, no qual a delimitação do ambiente da pesquisa possibilita uma observação mais aprofundada dos fenômenos ali existentes (LAVILLE; DIONNE, 1999). Ademais, tendo em vista que a pesquisadora é Analista Ambiental do Ibama desde 2005, evidentemente esta atua como observadora participante, aliando o conhecimento científico da Ciência da Informação à sua experiência profissional relacionada ao objeto, fazendo uso de uma sustentação teórico-empírica.

\subsection{DELIMITAÇÃO DO OBJETO}

O trabalho em tela está centrado nos processos relacionados às atividades-fim do Ibama, especialmente aquelas desenvolvidas nas superintendências estaduais: fiscalização, licenciamento ambiental, cadastro técnico federal e monitoramento e controle da biodiversidade. Isso porque, embora não seja difícil observar-se problemas na gestão das informações das atividades-meio (relacionadas à administração - licitações, contratos, recursos humanos, material, patrimônio etc.), tais atividades são comuns a todos os órgãos públicos e já possuem, em sua maioria, fluxos e procedimentos bem definidos para sua execução. Segundo Schellenberg (2006), as atividades caracterizadas como meios são as auxiliares, enquanto aquelas definidas como fins se referem ao trabalho técnico e profissional do órgão, ou seja, 
são as ações que distinguem a instituição das demais. Desse modo, os processos das atividades finalísticas são bastante específicos da autarquia, representando a sua finalidade, para a qual foi criada, e, portanto, relaciona-se ao conhecimento por vezes restrito ao Instituto.

Como forma de delimitar o universo de coleta dos dados, o estudo de caso se restringiu à Superintendência do Ibama em Pernambuco (Supes/PE), assegurando a coleta de uma amostra significativa quanto às atividades desenvolvidas e utilização dos sistemas de informação em um período de cinco anos, compreendendo os anos de 2013 a 2017, possibilitando uma análise quali-quantitativa dos dados. No entanto, visto que a Supes/PE desenvolve atividades comuns a todas as Superintendências do Ibama no Brasil, a análise reflete uma realidade existente nas diversas unidades descentralizadas do Instituto.

\subsection{COLETA DOS DADOS}

Os dados analisados na pesquisa são provenientes de duas fontes: documentais (documentos institucionais e legislação correlata) e dados registrados nos sistemas informatizados.

\subsubsection{Fontes documentais}

Os documentos institucionais relacionados no Quadro 4, tais como relatórios, programas, planejamentos, entre outros, além de se constituírem como instrumentos de coleta de dados, também subsidiam a análise crítica da realidade organizacional e auxiliam na compreensão das limitações e necessidades informacionais do Ibama.

Quadro 4 - Relação dos documentos institucionais do Ibama consultados.

\begin{tabular}{|l|l|}
\hline \multicolumn{1}{|c|}{ Documento } \\
$\begin{array}{l}\text { Carta de Serviços ao Cidadão } \\
\text { (2014) }\end{array}$ & $\begin{array}{l}\text { Detalha quais os serviços oferecidos pelo lbama, os } \\
\text { requisitos, as informações e os documentos } \\
\text { necessários, as etapas, os prazos e as formas de } \\
\text { acesso. }\end{array}$ \\
\hline $\begin{array}{l}\text { Manual do usuário SEI - versão } \\
3.0\end{array}$ & $\begin{array}{l}\text { Disponibiliza orientações de utilização do SEI. } \\
\text { Apresenta as características e descreve a operação } \\
\text { das funcionalidades do sistema para os usuários } \\
\text { finais. }\end{array}$ \\
\hline
\end{tabular}


Plano Estratégico do Ibama para o ciclo 2016-2019

(Portaria no 20 , de 08/08/2016, publicada no BS Especial no 08 , de 08/08/2016)

Plano de Dados Abertos - vigência 2018 a 2019

(2017)

Plano Diretor de Tecnologia da Informação e Comunicações (PDTIC)

do Ibama - 2017-2019

(2 $2^{\mathrm{a}}$ ed., 2018)

Relatório anual de atividades da

Auditoria Interna - exercício de 2017 (Publicado no Boletim de Serviço no 04, de 06/04/2018)
Estabelece as diretrizes para as ações do Ibama no período, definindo: missão; visão; mapa estratégico; indicadores; e portfólio de projetos estratégicos.

Divulga as ações e estratégias organizacionais que nortearão as atividades de implementação e promoção da abertura de dados, no âmbito do Ibama, de forma institucionalizada e sistematizada.

Registra o inventário de necessidades; os planos de metas e ações, de gestão de pessoas, orçamentário, de gestão de riscos, dentre outros elementos táticos relacionados à tecnologia da informação e comunicações.

Apresenta o relato sobre as atividades executadas em função das ações planejadas no Plano Anual de Atividades de auditoria Interna (PAINT) referente ao exercício anterior.

Fonte: Elaboração própria, 2019.

Além dos documentos descritos no Quadro 4, foram consultados processos administrativos e informações disponíveis na intranet do lbama, os quais são eventualmente citados no texto, além de dispositivos legais relativos ao lbama, os quais estão listados no Quadro 5.

Quadro 5 - Relação dos dispositivos legais relativos ao lbama.

\begin{tabular}{|c|c|}
\hline Dispositivo legal & Ementa \\
\hline $\begin{array}{l}\text { Lei } n^{\circ} 6.938 \text {, de } 31 \text { de } \\
\text { agosto de } 1981\end{array}$ & $\begin{array}{l}\text { Estabelece a Política Nacional do Meio Ambiente (PNMA), } \\
\text { constitui o Sistema Nacional do Meio Ambiente (Sisnama) e } \\
\text { institui o Cadastro de Defesa Ambiental. }\end{array}$ \\
\hline $\begin{array}{l}\text { Lei } n^{\circ} 7.735 \text {, de } 22 \text { de } \\
\text { fevereiro de } 1989\end{array}$ & $\begin{array}{l}\text { Cria o Instituto Brasileiro do Meio Ambiente e dos Recursos } \\
\text { Naturais Renováveis (Ibama) e dá outras providências. }\end{array}$ \\
\hline $\begin{array}{l}\text { Lei } n^{\circ} 8.159 \text {, de } 08 \text { de } \\
\text { janeiro de } 1991\end{array}$ & $\begin{array}{l}\text { Dispõe sobre a política nacional de arquivos públicos e privados e } \\
\text { dá outras providências }\end{array}$ \\
\hline $\begin{array}{l}\text { Lei } 9.605 \text {, de } 12 \text { de } \\
\text { fevereiro de } 1998 \text { - Lei dos } \\
\text { crimes ambientais. }\end{array}$ & $\begin{array}{l}\text { Dispõe sobre as sanções penais e administrativas derivadas de } \\
\text { condutas e atividades lesivas ao meio ambiente e dá outras } \\
\text { providências. }\end{array}$ \\
\hline $\begin{array}{l}\text { Lei } n^{\circ} 9.784 \text {, de } 29 \text { de } \\
\text { janeiro de } 1999\end{array}$ & $\begin{array}{l}\text { Regula o processo administrativo no âmbito da Administração } \\
\text { Pública Federal. }\end{array}$ \\
\hline $\begin{array}{l}\text { Lei } n^{\circ} 10.650 \text {, de } 16 \text { de abril } \\
\text { de } 2003\end{array}$ & $\begin{array}{l}\text { Dispõe sobre o acesso público aos dados e informações } \\
\text { existentes nos órgãos e entidades integrantes do Sisnama. }\end{array}$ \\
\hline $\begin{array}{l}\text { Lei } n^{0} 11.284 \text {, de } 2 \text { de } \\
\text { março de } 2006 .\end{array}$ & $\begin{array}{l}\text { Dispõe sobre a gestão de florestas públicas para a produção } \\
\text { sustentável; institui, na estrutura do Ministério do Meio Ambiente, } \\
\text { o Serviço Florestal Brasileiro - SFB; cria o Fundo Nacional de } \\
\text { Desenvolvimento Florestal - FNDF; e dá outras providências. }\end{array}$ \\
\hline
\end{tabular}




\begin{tabular}{|c|c|}
\hline $\begin{array}{l}\text { Lei } n^{\circ} 11.516 \text {, de } 28 \text { de } \\
\text { agosto de } 2007\end{array}$ & $\begin{array}{l}\text { Cria o Instituto Chico Mendes de Conservação da Biodiversidade } \\
\text { (ICMBio), altera a Lei no } 7.735 / 1989 \text { e dá outras providências. }\end{array}$ \\
\hline $\begin{array}{l}\text { Lei } n^{\circ} 12.527 \text {, de } 18 \text { de } \\
\text { novembro de } 2011 \text { - Lei de } \\
\text { Acesso à Informação (LAI). }\end{array}$ & $\begin{array}{l}\text { Regula o acesso a informações previsto no inciso XXXIII do art. } \\
5^{\circ} \text {, no inciso II do } \S 3^{\circ} \text { do art. } 37 \text { e no } \S 2^{\circ} \text { do art. } 216 \text { da } \\
\text { Constituição Federal; e dá outras providências. }\end{array}$ \\
\hline $\begin{array}{l}\text { Lei Complementar no } 140 \text {, } \\
\text { de } 8 \text { de dezembro de } 2011\end{array}$ & $\begin{array}{l}\text { Fixa normas, nos termos dos incisos III, VI e VII do caput e do } \\
\text { parágrafo único do art. } 23 \text { da Constituição Federal, para a } \\
\text { cooperação entre a União, os Estados, o Distrito Federal e os } \\
\text { Municípios nas ações administrativas decorrentes do exercício da } \\
\text { competência comum relativas à proteção das paisagens naturais } \\
\text { notáveis, à proteção do meio ambiente, ao combate à poluição } \\
\text { em qualquer de suas formas e à preservação das florestas, da } \\
\text { fauna e da flora; e altera a Lei no } 6.938 \text {, de } 31 \text { de agosto de } 1981 \text {. }\end{array}$ \\
\hline $\begin{array}{l}\text { Lei no } 12.682 \text {, de } 9 \text { de julho } \\
\text { de } 2012\end{array}$ & $\begin{array}{l}\text { Dispõe sobre a elaboração e o arquivamento de documentos em } \\
\text { meios eletromagnéticos. }\end{array}$ \\
\hline $\begin{array}{l}\text { Decreto } n^{\circ} 8.539 \text {, de } 8 \text { de } \\
\text { outubro de } 2015\end{array}$ & $\begin{array}{l}\text { Dispõe sobre o uso do meio eletrônico para a realização do } \\
\text { processo administrativo no âmbito dos órgãos e das entidades da } \\
\text { administração pública federal direta, autárquica e fundacional. }\end{array}$ \\
\hline $\begin{array}{l}\text { Decreto } n^{\circ} 8.638 \text {, de } 15 \text { de } \\
\text { janeiro de } 2016\end{array}$ & $\begin{array}{l}\text { Institui a Política de Governança Digital no âmbito dos órgãos e } \\
\text { das entidades da administração pública federal direta, autárquica } \\
\text { e fundacional. }\end{array}$ \\
\hline $\begin{array}{l}\text { Decreto } n^{\circ} 8.777 \text {, de } 11 \text { de } \\
\text { maio de } 2016\end{array}$ & Institui a Política de Dados Abertos do Poder Executivo federal. \\
\hline $\begin{array}{l}\text { Decreto no } 8.973 \text {, de } 24 \text { de } \\
\text { janeiro de } 2017\end{array}$ & $\begin{array}{l}\text { Aprova a estrutura regimental e o quadro demonstrativo dos } \\
\text { cargos em comissão do lbama e dá outras providências. }\end{array}$ \\
\hline $\begin{array}{l}\text { Instrução Normativa Ibama } \\
\text { no } 10 / 2012\end{array}$ & $\begin{array}{l}\text { Regula os procedimentos para apuração de infrações } \\
\text { administrativas por condutas e atividades lesivas ao meio } \\
\text { ambiente, a imposição das sanções, a defesa, o sistema recursal } \\
\text { e a cobrança de multas no âmbito do lbama. }\end{array}$ \\
\hline $\begin{array}{l}\text { Portaria } n^{\circ} 9 \text {, de } 5 \text { de junho } \\
\text { de } 2012\end{array}$ & $\begin{array}{l}\text { Institui a Política de Segurança da Informação, Informática e } \\
\text { Comunicações (Posic) do Instituto Brasileiro do Meio Ambiente e } \\
\text { dos Recursos Naturais Renováveis (Ibama). }\end{array}$ \\
\hline $\begin{array}{l}\text { Portaria lbama } n^{\circ} 24 \text {, de } 16 \\
\text { de agosto de } 2016\end{array}$ & Aprova o Regulamento Interno de Fiscalização Ambiental (RIF) \\
\hline $\begin{array}{l}\text { Portaria lbama } n^{\circ} 09 \text {, de } 24 \\
\text { de abril de } 2017 \text {. }\end{array}$ & $\begin{array}{l}\text { Estabelece e padroniza os procedimentos do processo eletrônico } \\
\text { e gestão de documentos, processos e arquivo pelo Sistema } \\
\text { Eletrônico de Informações - SEI no âmbito do Ibama. }\end{array}$ \\
\hline $\begin{array}{l}\text { Portaria lbama no 14, de } 29 \\
\text { de junho de } 2017\end{array}$ & nento Interno do Ibama \\
\hline
\end{tabular}

Fonte: Elaboração própria, 2019.

\subsubsection{Dados registrados nos sistemas}

A coleta de dados relativos às informações armazenadas se concentrou nos seguintes sistemas informacionais do Ibama: 
a. Sistema Integrado de Cadastro, Arrecadação e Fiscalização (Sicafi) relativo às atividades de fiscalização e cadastro, que representam o maior volume de processos relacionados às atividades finalísticas do Instituto; e

b. Sistema Eletrônico de Informações (SEI) - sistema de gestão documental utilizado pelo Ibama desde maio de 2017.

Do Sicafi foram extraídos os dados referentes aos autos de infração (Al) lavrados pela equipe de Fiscalização da Supes/PE no período de 2013 a 2017. Tais dados foram obtidos com a emissão, no sistema, dos relatórios anuais de $\mathrm{Al}$, os quais foram gerados em formato PDF (ver Figura 5, a seguir) e posteriormente convertidos em planilha Microsoft Excel ${ }^{22}$ para possibilitar sua manipulação. Os dados foram uniformizados, excluindo-se as informações pessoais dos autuados, e reunidos em uma única planilha, para posterior aplicação de técnicas de visualização da informação. Essa planilha pode ser consultada no Apêndice B.

No SEl foram coletados os registros de processos administrativos de 2013 a 2017, em tramitação na Supes/PE, com demandas de trabalhos técnicos solicitados pelo Ministério Público Federal e Estadual. Para identificação de tais processos, foi utilizada a ferramenta de pesquisa avançada do SEI, com o termo "ministério público", limitando aos documentos gerados pelo COAD-PE - NÚCLEO DE COMUNICAÇÃO ADMINISTRATIVA (PROTOCOLO, ARQUIVO E SERVIÇOS GERAIS) ${ }^{23}$. A seleção dos documentos através do COAD-PE foi feita para que a pesquisa tivesse uma maior precisão, ao recuperar somente os documentos externos recebidos, e não aqueles enviados pelo lbama ou que somente mencionam o MP.

\footnotetext{
22 Há vários conversores de arquivos disponíveis gratuitamente na internet. Para este trabalho, utilizamos o Nitro (https://www.pdftoexcelonline.com/pt/) pra efetuar a conversão dos arquivos PDF para Excel.

23 COAD - NÚCLEO DE COMUNICAÇÃO ADMINISTRATIVA é o nome pelo qual atualmente é designado o setor de Protocolo do Ibama e PE designa a unidade federativa. É, portanto, onde são recebidos e registrados os documentos externos.
} 
Figura 5 - Página de relatório gerado pelo Sicafi.

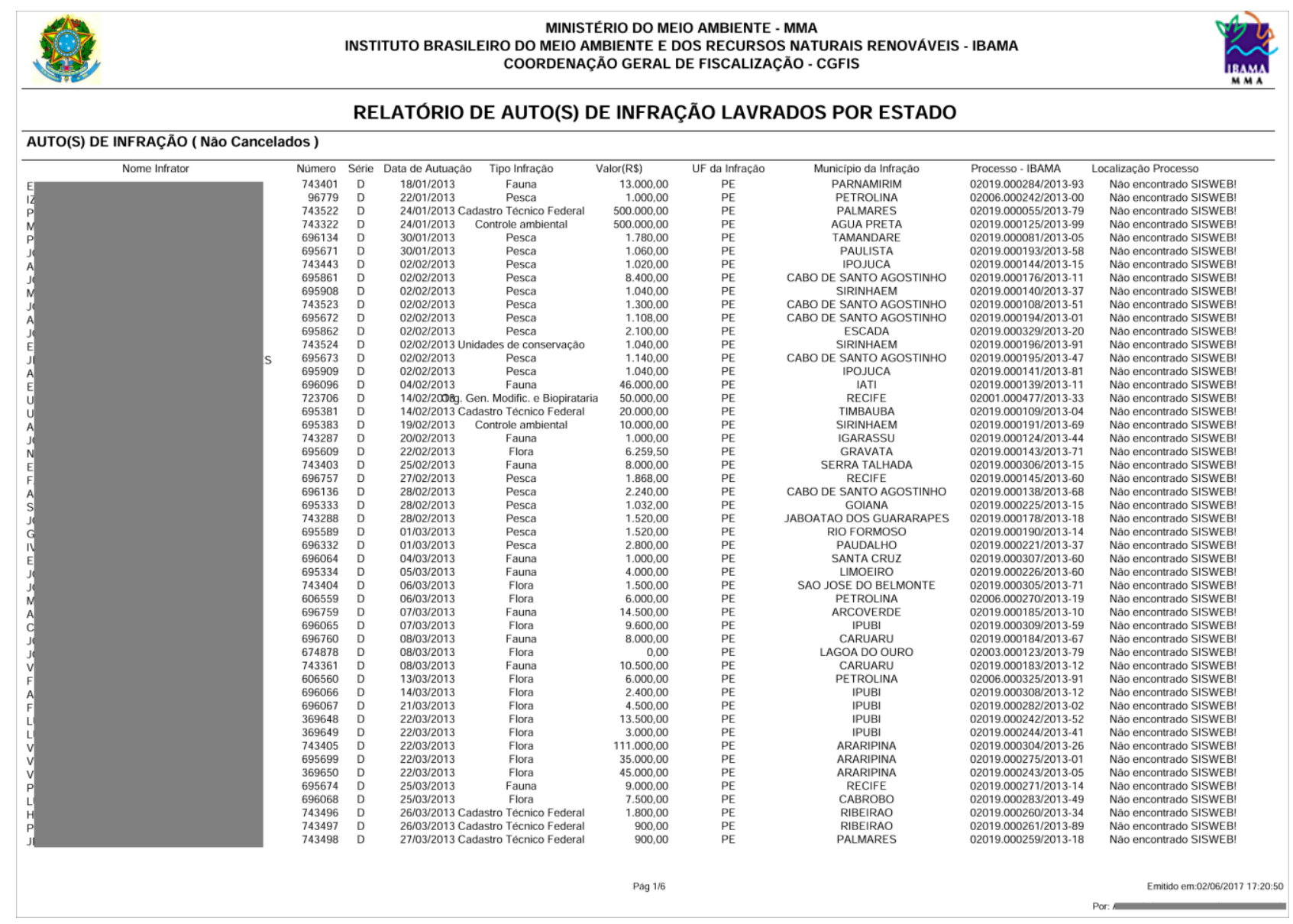

No relatório acima, foram tarjados os dados dos autuados e do emissor do relatório. Fonte: Sicafi.

A pesquisa no SEl com as especificações citadas, realizada em 21/06/2018, revocou 482 documentos, apresentados em páginas a cada dez registros, em ordem decrescente de data, conforme vê-se na Figura 6. 
Figura 6 - Primeira página com o resultado da pesquisa no SEI.

$21 / 06 / 2018$

SEI - Resultado da Pesquisa

INSTITUTO BRASILEIRO DO MEIO AMBIENTE E DOS RECURSOS NATURAIS RENOVÁVEIS

Para saber+ Menu Pesquisa

SUPES-PE $\mathbf{~} \equiv$

$\boldsymbol{N} \&$ \&

\section{Resultado da Pesquisa}

"ministério público"

(?) Pesquis:

Pesquisar em: $\quad$ Documentos Gerad Documentos Exter $\checkmark$ Com Tramitação na Unidade

Órgão Gerador: $\quad$ Todos selecionados

Unidade Geradora: COAD-PE - NÚCLEO DE COMUNICAÇÃO ADMINISTRATIVA (P

Assunto:

Assinatura /

Autenticação :

Contato:

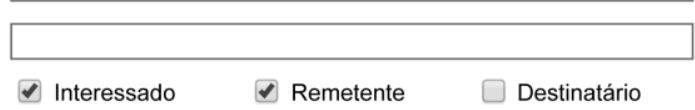

Especificação /

Descrição:

Obs. desta Unidade:

No SEl:

(Processo / Documento)

Tipo do Processo:

Tipo do Documento:

Número / Nome na

Árvore:

Data do Processo /

Periodo explícito

30 dias

60 dias

Usuário Gerador:

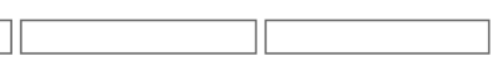

Exibindo 1 - 10 de 482

Demanda Externa: Orgãos Governamentais Federais № 02019.001976/2018-63 ( Ofício 0808281-32-4.05.8300-18,PEDIDO DE APRESENTAÇÃO OBS

2640083

CARTA PRECATÓRIA CRIMINAL DEPRECANTE: MINISTÉRIO PÚBLICO FEDERAL e outru DEPRECADO: CARLOS ALBERTO ...

Unidade Geradora: COAD-PE Usuário: alexssandro.moura Data: 20/06/2018

Demanda Externa: Ministério Público Federal № 02019.001975/2018-19 (Pedido DE INTERPOR DA DECISÃO DO ARQUIVAMENTO DO INQ.)

2638382

DOC; Nº2019001975-2018-19 PR-PE.00029933120 1R IMINISTÉRIO PÚBLICO FEDERAL ... encaminhados ao respectivo Órgão Revisor (Câmara de Coordenação e Revisào do Ministério Público ...
Unidade Geradora: COAD-PE
Usuário: alexssandro.moura
Data: $19 / 06 / 2018$

Demanda Externa: Ministério Público Federal № 02019.001974/2018-74 (Ofício 3106-2017 PEDIDO INTERPOR RECURSO )

https://sei.ibama.gov.br/controlador.php?acao=protocolo_pesquisar\&acao_origem=protocolo_pesquisar\&infra_sistema=100000100\&infra_unidad...

Fonte: Elaboração própria (2018), a partir de pesquisa no SEI. 
Observa-se que o resultado da consulta apresenta a lista de documentos sem muito detalhamento, sendo necessário abrir um a um os registros, a fim de identificar os respectivos assuntos e demais dados necessários à pesquisa. Em razão de eventuais falhas no processamento do OCR (reconhecimento ótico de caracteres, da sigla em inglês) dos documentos digitalizados, em alguns casos o texto aparece truncado no resultado da busca, como mostrado na Figura 7. Por tais motivos, não foi possível identificar critérios que pudessem incrementar a precisão da busca no sistema.

Figura 7 - Exemplo de registro com falhas na leitura do texto.

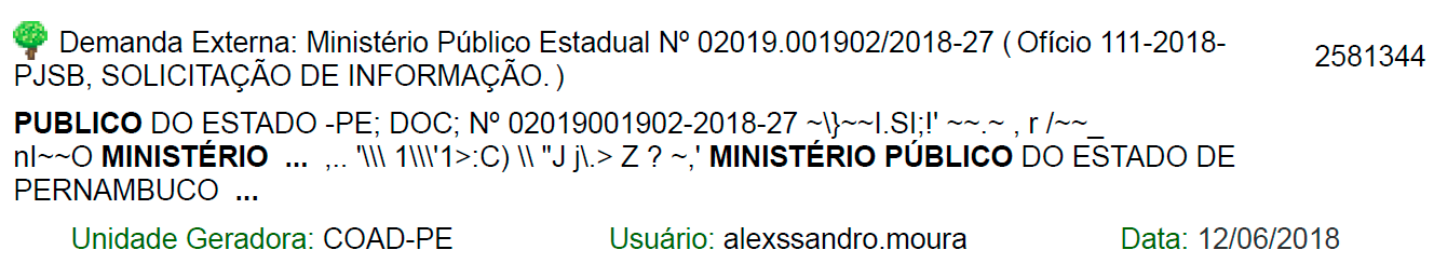

Fonte: Elaboração própria (2018), a partir de pesquisa no SEI.

Salienta-se, ainda, que o sistema não possibilita a geração de planilha ou qualquer documento editável com o resultado da busca, nem mesmo a listagem em página única, não sendo possível também salvar o resultado da pesquisa para consulta posterior. Assim, foram salvas as 49 telas resultantes da pesquisa em formato PDF, para posterior consulta aos processos individualmente, a fim de identificar aqueles que atendiam aos critérios da amostragem.

Dos registros consultados, foram identificados os documentos que integram processos do período delimitado (2013 a 2017) e selecionados aqueles com solicitações do Ministério Público que implicassem em trabalhos técnicos a serem executados pelo lbama, tais como levantamentos, vistorias, análises, entre outros. Assim, foram excluídos da amostragem documentos como: reiterações, convocações para audiências, notícias de instauração ou arquivamento de inquéritos, as simples requisições de cópias de processos ou de informações sobre julgamento ou quitação de débitos, bem como os documentos de terceiros que citavam o MP. Esta triagem resultou em um total de 41 processos, cujos dados foram organizados em uma planilha, detalhando os metadados disponíveis no sistema e as informações colhidas da leitura dos documentos, conforme vê-se no Apêndice $\mathbf{C}$. Os dados referentes a pessoas físicas ou jurídicas (nome e CPF ou CNPJ), bem como os nomes de propriedades privadas, foram tachados e parcialmente excluídos, de modo a evitar 
sua identificação, sendo mantidos só os caracteres inicias, a fim de identificar o tipo de informação que consta no respectivo campo.

\subsection{ANÁLISE DOS DADOS - VISUALIZAÇÃO DA INFORMAÇÃO}

Para subsidiar a interpretação dos dados coletados, foram utilizadas técnicas de visualização da informação, possibilitando uma observação abrangente do objeto de estudo.

A visualização da informação foi utilizada como a principal ferramenta para o mapeamento dos dados dos sistemas informacionais, com o intuito de identificar os tipos de informações encontrados nos processos e suas relações, bem como as lacunas e redundâncias existentes, desenvolvendo uma análise quali-quantitativa dos dados das planilhas.

As técnicas de visualização de informações têm se desenvolvido substancialmente nas últimas décadas, amparas pela computação gráfica, design de interação e mineração de dados, com o objetivo de facilitar a compreensão e interpretação de grandes quantidades de dados. Tais técnicas nada mais são do que a busca pela melhor forma de representar graficamente um conteúdo originalmente não visual, de modo que se mostre claramente as informações desejadas (FREITAS et al, 2001; NASCIMENTO; FERREIRA, 2011).

Uma vez que a linguagem visual é mais natural e requer menor esforço cognitivo que a linguagem escrita, a utilização de gráficos, figuras, esquemas ou outros tipos de representação visual permite condensar em uma imagem uma grande quantidade de dados e assim possibilita uma maior rapidez na transmissão de uma mensagem, como também a descoberta de novas informações antes ocultas em meio à massa de dados (DIAS; CARVALHO, 2007).

De acordo com Nascimento e Ferreira (2011), a opção pelo termo "visualização de informações", em detrimento a "visualização de dados" (uma vez que os gráficos são gerados a partir dos dados disponíveis), se justifica "uma vez o foco do processo é em compreender as informações acerca da relação entre os dados, mais do que observar seus valores isolados propriamente ditos" (NASCIMENTO; FERREIRA, 2011, p. 20). Para tanto, os autores enfatizam dois critérios essenciais para a linguagem gráfica: a expressividade e a efetividade. 
Uma visualização pode ser considerada expressiva se ela é capaz de mostrar todos os dados de interesse do usuário e nada mais.

Já a efetividade está relacionada com a apresentação das informações de forma clara. Para ser efetiva, uma visualização deve ser de fácil e rápida percepção e induzir a uma quantidade menor de erros de interpretação do que outras formas de se visualizar os mesmos dados.

Expressividade e efetividade são aspectos importantes porque, sem os mesmos, uma visualização pode não ser capaz de enfatizar padrões relevantes nos dados, não trazendo, assim, quaisquer informações novas além daquilo que já é trivialmente conhecido. Além disso, uma visualização também pode ser de difícil entendimento ou, até mesmo, sugerir interpretações errôneas, que na verdade não condizem com o significado dos dados. (NASCIMENTO; FERREIRA, 2011, p. 20-21).

Em outras palavras, deve-se observar o princípio da máxima informação com o mínimo de poluição, ou seja, a visualização deve ser equilibrada, apresentando quantidade suficiente de dados de forma mais simples possível, sem gráficos ou textos desnecessários. É importante que sejam observados, também: a legibilidade; a clareza da associação de atributos; a uniformidade nas escalas e unidades utilizadas; e a associação de símbolos ou atributos visuais (forma, cor, posição etc.) ao conteúdo, de modo a facilitar a percepção dos padrões existentes nos dados.

A partir dos modelos visuais e de acordo com a interação desses modelos com o usuário, é possível trabalhar os dados de forma analítica, em um processo também conhecido como mineração de dados (do inglês data mining). Esse processo permite a extração de dados analíticos ocultos em meio a grandes registros, utilizando-se técnicas matemáticas e estatísticas com o auxílio de ferramentas de computação gráfica, com o objetivo de revelar e apresentar informações de forma compreensível ao homem (VETRIVEL et al, 2017).

Com essa técnica, é possível identificar padrões e relações entre os dados antes invisíveis, permitindo, assim, a geração de esquemas e modelos preditivos para auxiliar no planejamento, recuperação de informações e decisão dentro de uma organização (AVELAR et al, 2017). Amplamente utilizada nas áreas de finanças e marketing - com o intuito de encontrar padrões e tendências de mercado - esse processo foi também abraçado pela bibliometria, mas apresenta potencial para aplicação na análise de qualquer banco de dados.

Os gráficos apresentados neste trabalho - gerados a partir dos dados coletados nos sistemas informatizados - foram produzidos com as ferramentas de mapas 3D e gráficos dinâmicos disponíveis no software Microsoft Excel. 


\section{RESULTADOS E ANÁLISES}

A seguir estão relatadas as observações fruto da pesquisa ora apresentada, primeiramente com as considerações em relação aos dados coletados nos sistemas Sicafi e SEI, e, em seguida, acerca do contexto institucional, dos sistemas informatizados e da gestão da informação no lbama de forma geral. Ao final, discorre-se sobre algumas propostas com o intuito de contribuir para o desenvolvimento da gestão da informação da organização.

\subsection{SICAFI}

O Sistema Integrado de Cadastro, Arrecadação e Fiscalização (Sicafi) reúne os dados referentes ao Cadastro Técnico Federal - de Atividades e Instrumentos de Defesa Ambiental (CTF/AIDA) e de Atividades Potencialmente Poluidoras e/ou Utilizadoras de Recursos Ambientais - e às sanções aplicadas pela Fiscalização do Ibama, além das informações referentes aos débitos relativos a taxas e multas decorrentes do CTF ou das atividades de fiscalização. Assim, o Sicafi concentra, em termos gerais, a maior parte das informações das atividades reguladas pelo lbama, sejam lícitas (CTF) ou ilícitas (Fiscalização).

Observa-se que, embora possua uma base de dados rica e extensa, o Sicafi é bastante limitado no que diz respeito às consultas e relatórios. Não é difícil obter informações sobre uma pessoa física ou jurídica específica (desde que com o respectivo CPF ou CNPJ). Mas o mesmo não acontece para emitir relatórios gerenciais que permitam, por exemplo, listar todos os empreendimentos de alto potencial poluidor cadastrados no CTF ou identificar os tipos de autuação mais frequentes em determinada região. Além disso, a maior parte dos relatórios que podem ser emitidos pelo sistema só são gerados em formato PDF, o que dificulta a manipulação e análise dos dados. Embora seja possível converter para o formato de planilha, com softwares específicos, é comum que o processo de conversão gere erros que exige atenção e trabalho adicional para "limpeza" dos dados, o que se torna tanto mais complexo quanto maior for a quantidade de dados em operação.

Sendo um sistema bastante antigo e de grande complexidade, o Sicafi apresenta muita dificuldade para que seja feita qualquer atualização do sistema, pois 
não raro uma alteração pontual repercute em outros módulos e, tendo em vista que por ele é gerida toda a área de arrecadação do Ibama, os riscos de prejuízos para o órgão ou para os administrados são bastante sérios. Têm-se notícia (não confirmada oficialmente) de que o Ibama está estudando a possibilidade de implantar um outro sistema que faça a interface entre o banco de dados do Sicafi e os usuários internos. Esse seria uma alternativa mais segura para gerir as informações armazenadas no sistema sem ameaçar a sua estabilidade, possibilitando a geração, por exemplo, de relatórios gerenciais mais completos e customizáveis.

\subsubsection{Autos de Infração}

Sem dúvida, as ações do Ibama que têm maior visibilidade para o público externo são relativas ao trabalho da Fiscalização Ambiental. Por esse motivo, optouse por tomar os Autos de Infração como um dos objetos de observação deste trabalho.

Segundo o Regulamento Interno da Fiscalização Ambiental (RIF), o Auto de infração (Al) é o "documento destinado a fazer o enquadramento da infração ambiental, sua descrição objetiva, a indicação de sanções e a qualificação do autuado" (Art. 64, I, da Portaria Ibama no 24/2016). O Auto de Infração pode estabelecer a sanção de multa ou advertência e tem seu processo instruído obrigatoriamente com 0 Relatório de Fiscalização e outros anexos (laudos, relatório fotográfico, etc.), para que, garantida a ampla defesa e o contraditório, seja confirmado por autoridade julgadora administrativa para produzir efeito legal.

Além do $\mathrm{Al}$, outros termos são lavrados pelos agentes de fiscalização para solicitar esclarecimentos ou determinar a correção de irregularidades (notificação), indicação de sanções administrativas (termos de apreensão, suspensão, embargo ou interdição) e para formalizar a destinação de bens apreendidos (termos de depósito, doação, soltura, entrega de animais silvestres, demolição ou destruição/inutilização). $\mathrm{Na}$ maior parte das vezes, esses termos são vinculados ao Al e integram o mesmo processo administrativo, sendo julgados conjuntamente ${ }^{24}$. Por isso, o Al figura como

o principal documento dos processos de fiscalização, cujos procedimentos são

\footnotetext{
${ }^{24}$ Como exceção temos, por exemplo, os casos de materiais ilícitos que são abandonados e não há identificação do infrator, sendo o processo aberto com o Termo de Apreensão e julgado sem a vinculação a um Auto de Infração.
} 
regulados pela Instrução Normativa Ibama no 10/2012. Pode-se observar um modelo básico do fluxo dos processos de Autos de Infração no Apêndice $A$.

Desde 2013, o Ibama adotou o Al eletrônico (Al-e), passando os autos de infração e demais termos a serem lavrados no equipamento eletrônico PDA (Personal Digital Assistant). Os documentos lavrados são impressos no próprio PDA (para assinatura do agente autuante e ciência do autuado) e posteriormente sincronizados para transferência dos dados para o Sicafi. Ou seja, os dados que entram no sistema são exatamente aqueles que foram registrados nos documentos pelo agente de fiscalização, o que reduz a probabilidade de erros na entrada de dados. Já para composição do processo administrativo, os documentos são digitalizados e incluídos do SEI (ver Figura 8). Antes da adoção do Al-e, em 2012, os documentos eram lavrados em blocos impressos, com numeração controlada, e posteriormente copiados para o Sicafi por meio de digitação.

Para a amostragem deste trabalho, foram coletados os dados referentes aos Autos de Infração lavrados pelo Ibama em Pernambuco no período de 2013 a 2017, conforme se vê no Apêndice B. $O$ intuito dessa coleta foi observar as possibilidades de manipulação dos dados armazenados pelo sistema do Ibama, para seu uso na gestão da informação do Instituto.

Utilizando-se técnicas de visualização da informação, foram gerados os gráficos vistos nas Figuras 9 a 14, nos quais pode-se observar facilmente a distribuição geográfica das autuações nos municípios do estado de Pernambuco, como também a variação anual do quantitativo de multas aplicadas e de seus respectivos valores. Da mesma forma, é possível gerar diversos outros gráficos cruzando-se os dados disponíveis, delimitando-se ou ampliando o período, especificando os tipos de infrações ou tantas outras variações. 
Figura 8 - Exemplo de Auto de Infração lavrado pela Fiscalização

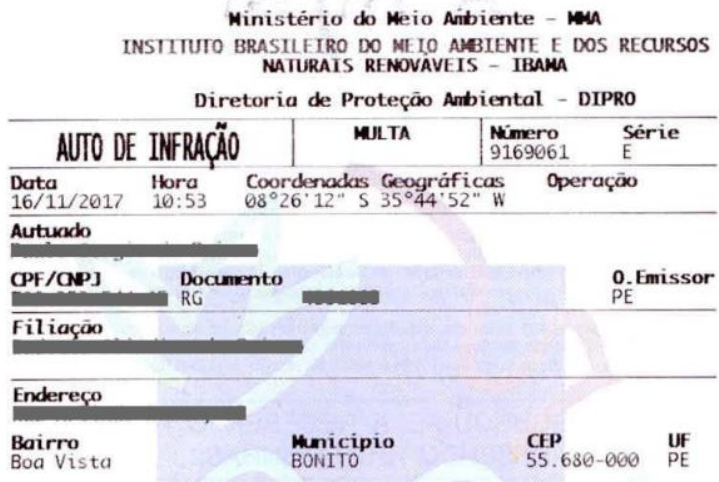
Descriçäo da Infraçāo
Ter em cativeiro 29 espécimes da fauna silvestre nativa e 3
especimes abatidos sem autorizaçao da autoridade ambiental especimes
competente.

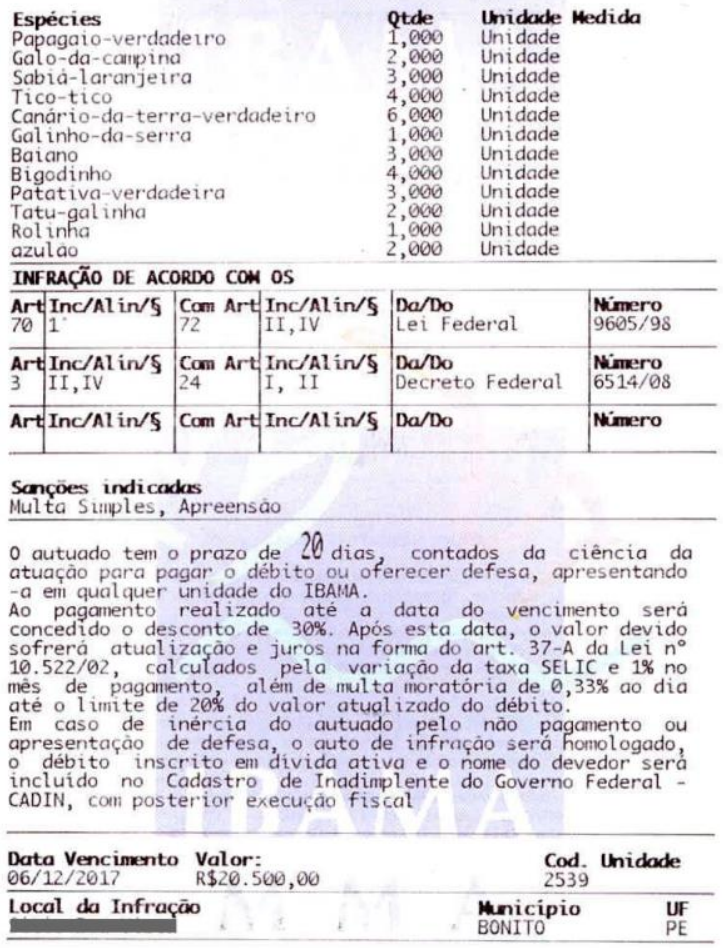

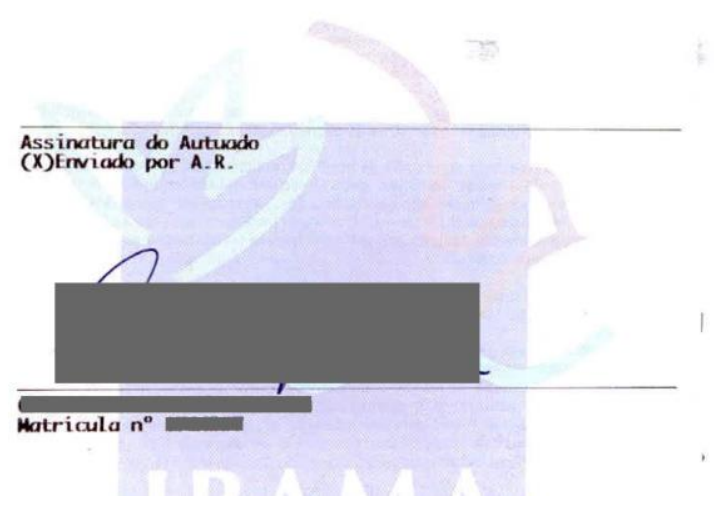

No Al acima, foram tarjados os dados do autuado e do agente autuante. Fonte: SEI. 
Figura 9 - Distribuição geográfica das autuações de 2013 a 2017, nos municípios de Pernambuco.

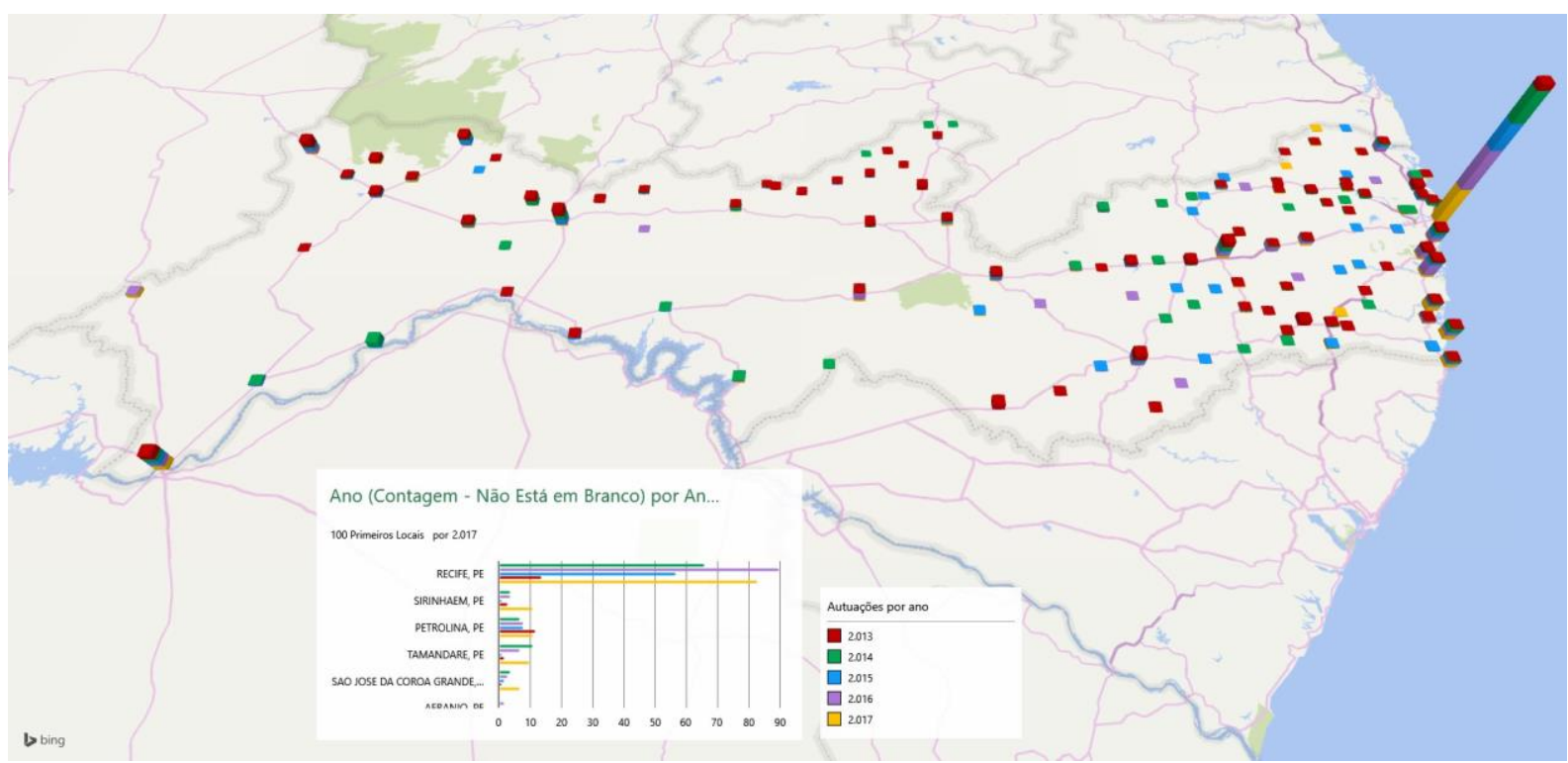

Fonte: Elaboração própria, 2019.

Figura 10 - Distribuição geográfica por tipo de infração, nos municípios de Pernambuco.

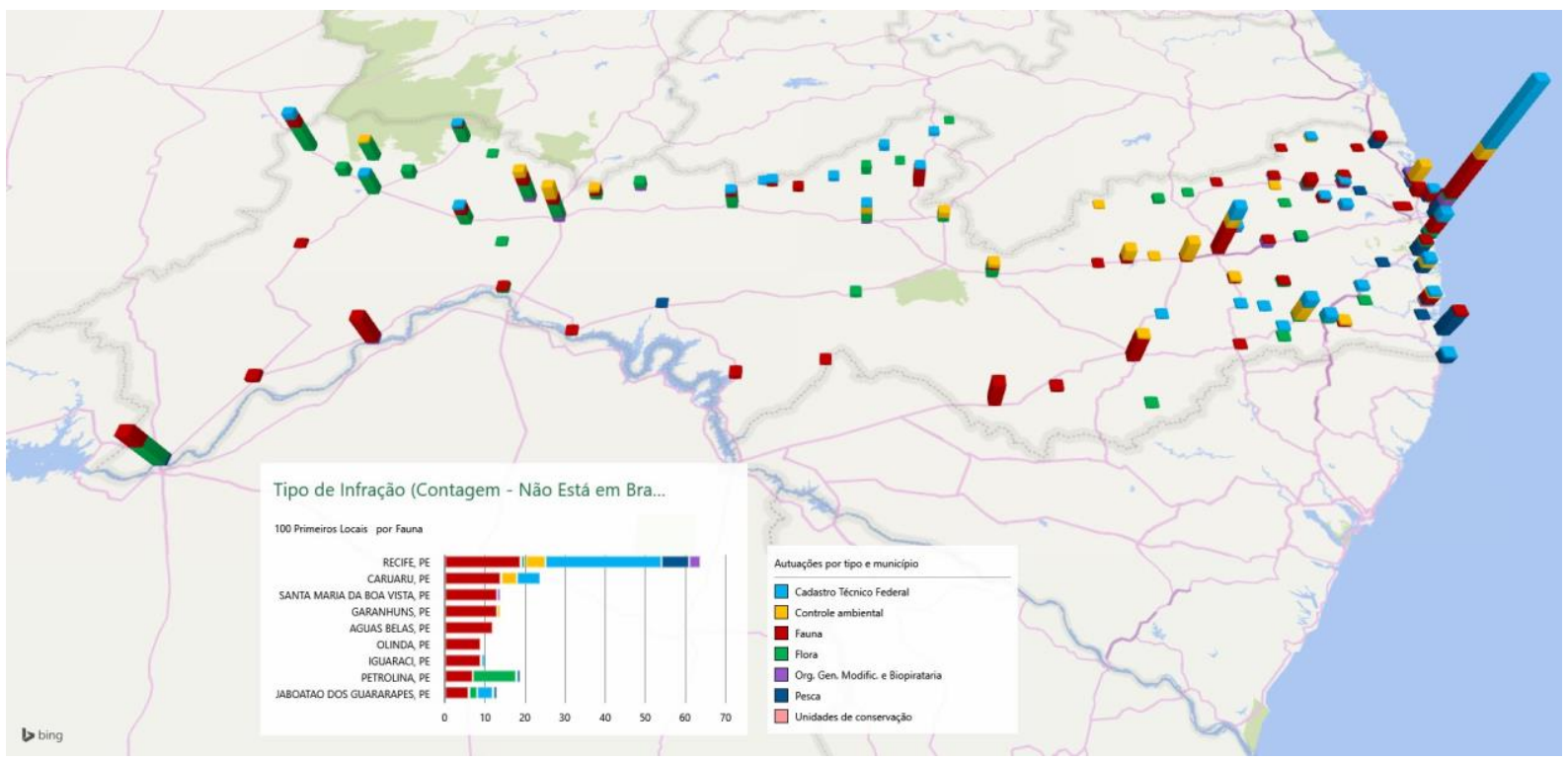

Fonte: Elaboração própria, 2019. 
Figura 11 - Quantidade de Autos de Infração lavrados por ano

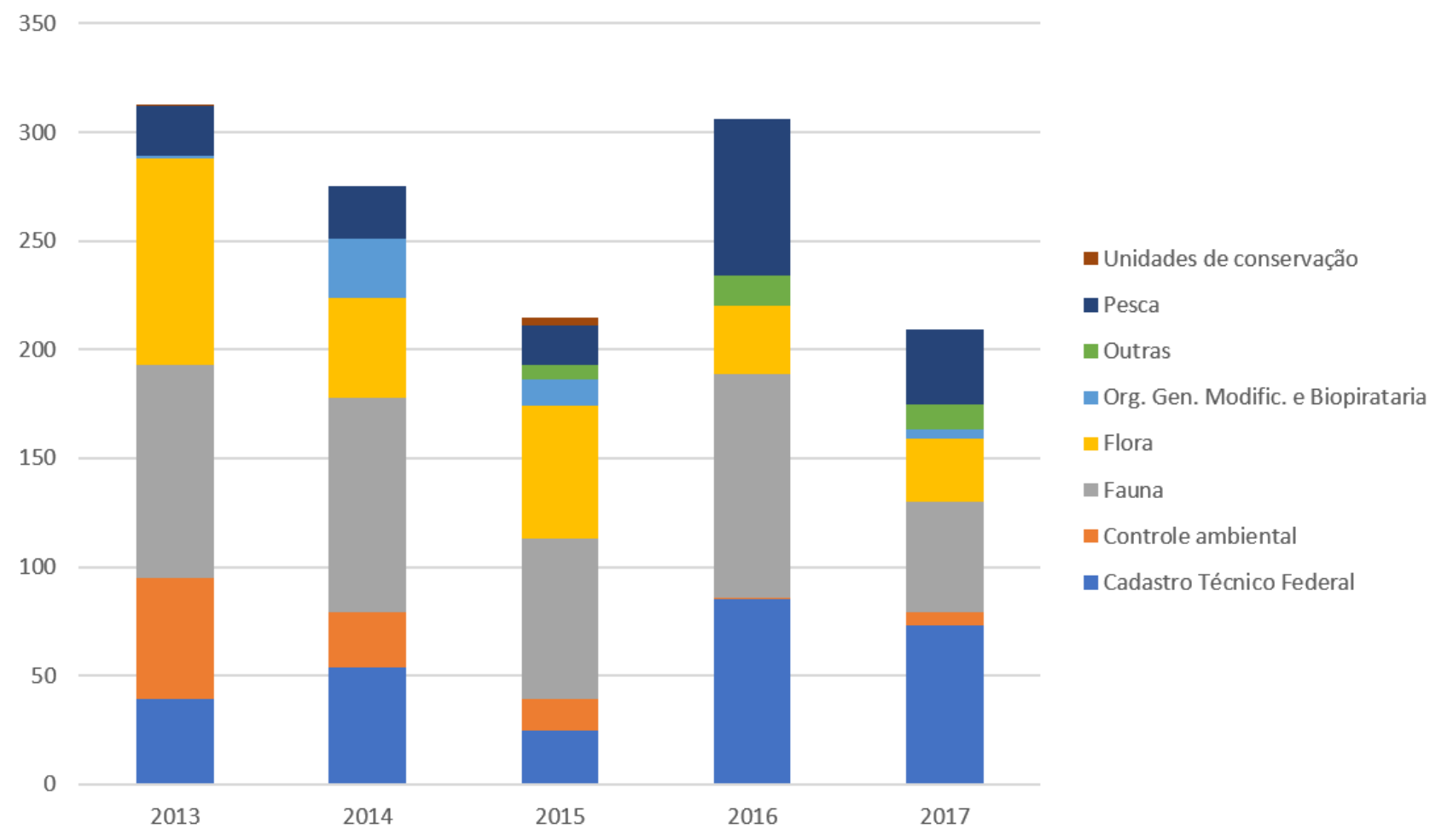

Fonte: Elaboração própria, 2019.

Figura 12 - Variação da quantidade de Al por tipo de infração

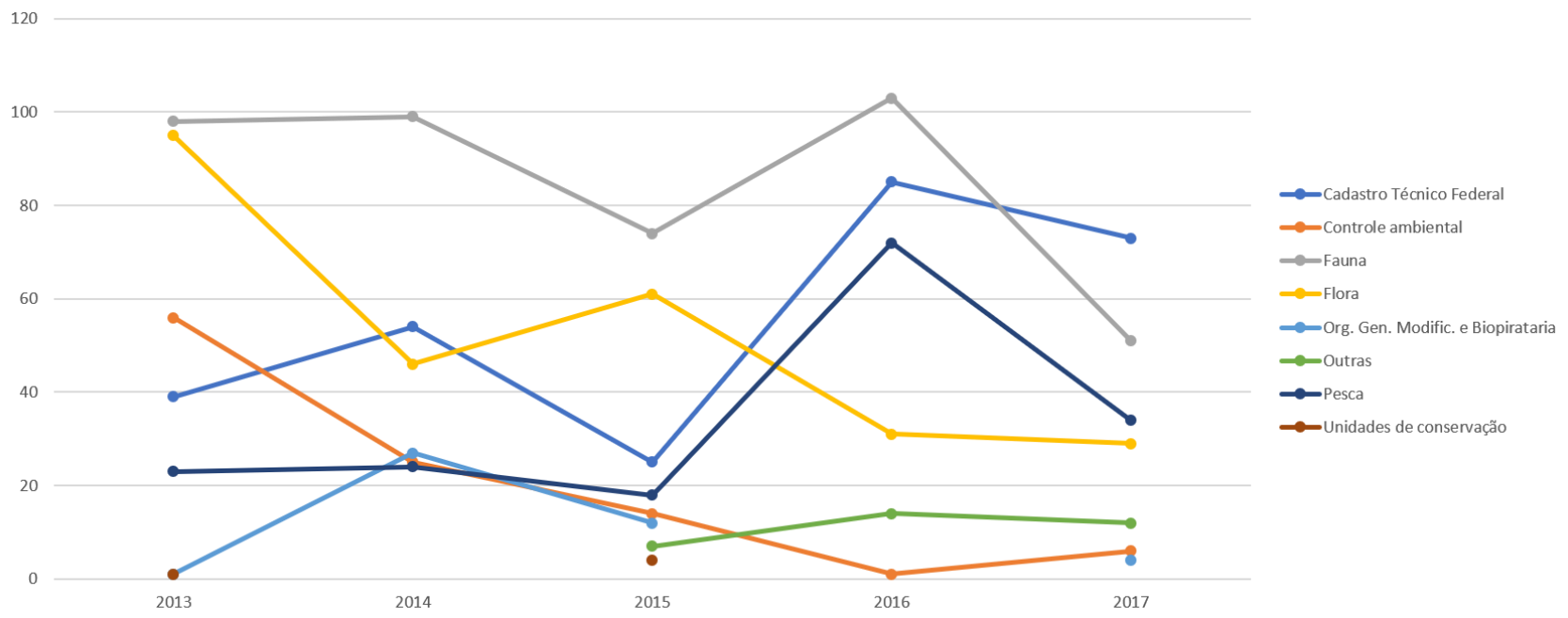

Fonte: Elaboração própria, 2019. 
Figura 13 - Valores totais das multas aplicadas por ano

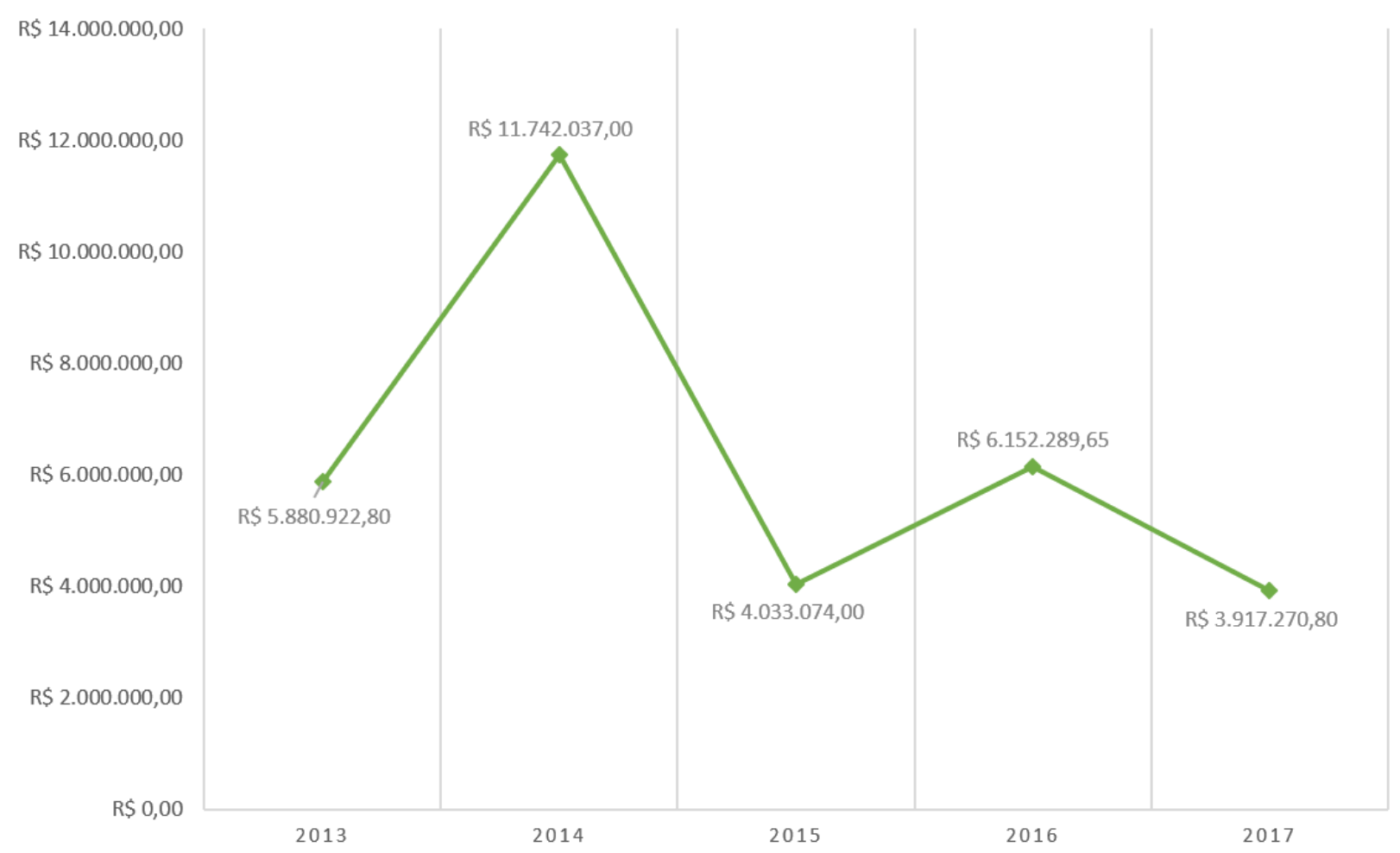

Fonte: Elaboração própria, 2019.

Figura 14 - Valores totais das multas aplicadas por ano e por tipo de infração

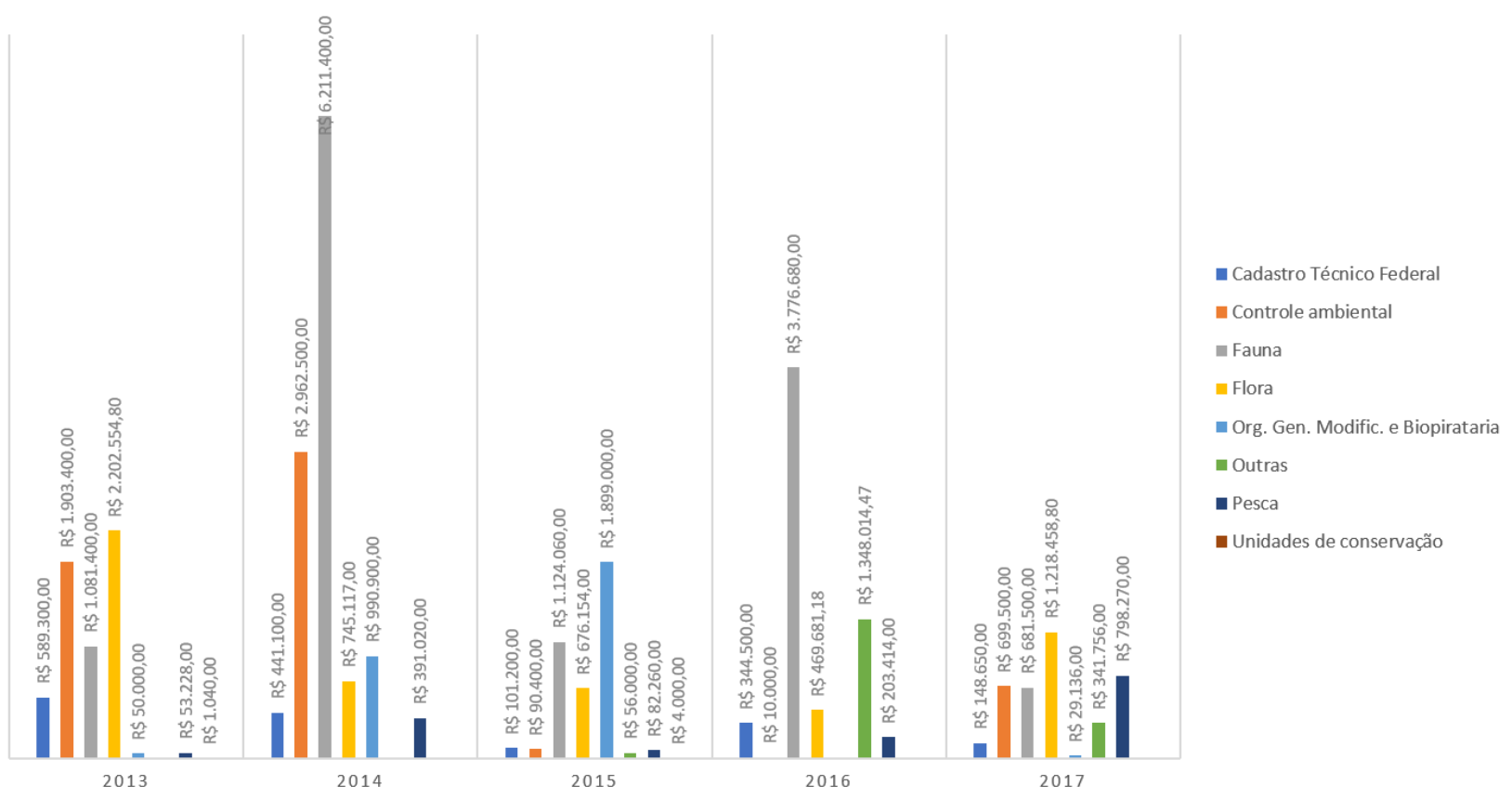

Fonte: Elaboração própria, 2019. 
Analisando os gráficos anteriores (Figuras 9 a 14), pode-se inferir, por exemplo, que entre os anos 2013 e 2017 houve um decréscimo considerável das autuações referentes à flora, possivelmente devido à transferência da gestão florestal para o órgão estadual. Evidentemente, uma análise consistente dos gráficos só é possível com o suporte de outras fontes de informação, tais como relatórios das operações de fiscalização realizadas. No entanto, o que se quer demonstrar aqui é a possibilidade de apresentação das informações de modo que facilite, ao analista ou tomador de decisão, a compreensão dos dados disponíveis.

Ressalta-se que não há aqui a pretensão de esgotar as possibilidades de visualização da informação a partir dos dados coletos, mas sim demonstrar o potencial existente nos dados armazenados pelo Ibama em seus sistemas de informação.

\subsection{SEI}

O Sistema Eletrônico de Informações (SEI) foi adotado pelo Ibama em 2017, sendo que, a partir de maio desse ano, todos os processos e documentos produzidos pelo Instituto encontram-se nesse sistema. Entre as vantagens previstas com a utilização do SEI (dentre aquelas já relacionadas na seção 3.3), destaca-se a agilidade na tramitação dos processos, a redução quase a zero da necessidade de impressão em papel (limitada a correspondências externas) e a facilidade na disponibilização para acesso externo, inclusive para atendimento à Lei de Acesso à Informação (LAI).

Entretanto, observa-se que o sistema ainda precisa evoluir bastante, sobretudo no que se refere à ferramenta de busca e ao tratamento arquivístico dos documentos, tal como destacado pelo Arquivo Nacional (2015) e por Venancio e Feitler (2018), e como se pode ver na análise a seguir.

\subsubsection{Demandas do Ministério Público}

A opção pela amostragem dos processos do SEl a partir de demandas do Ministério Público (MP) se deu em razão dessa ser uma necessidade bastante frequente no dia a dia do Instituto, tanto que a Presidência do Ibama solicitou a todas as unidades, pelo Memorando-Circular no 11/2018/GABIN, de 15/06/2018, o levantamento das requisições, feitas pelo MP na esfera federal ou estadual, de trabalhos técnicos do Ibama, tais como vistorias, laudos, análises e outros (processo 
nº 02001.007181/2018-58). Esse tipo de requisição preocupa muito o Instituto porque implica em ações fora do planejamento anual de cada unidade e exigem a dedicação de tempo dos servidores e, por vezes, também recursos financeiros para realização de vistorias em campo. Além disso, não é incomum que as solicitações do MP sejam de competência de órgãos de outra esfera de governo (estadual ou municipal), e seu atendimento pelo lbama chega a comprometer a execução das atividades previstas.

A partir desse levantamento e com o recorte temporal estabelecido na pesquisa (2013 a 2017), chegou-se ao número de 41 processos ${ }^{25}$, os quais estão listados na planilha do Apêndice C. Os dados levantados para cada processo foram os seguintes:

Quadro 6 - Relação dos campos de dados dos processos coletados no SEl.

\begin{tabular}{|c|c|}
\hline Nome do campo & Descrição \\
\hline \multicolumn{2}{|c|}{ METADADOS DO PROCESSO NO SEI } \\
\hline Processo no & Número de identificação do processo. \\
\hline Data de Autuação & Data de criação do processo. \\
\hline Tipo do Processo & $\begin{array}{l}\text { Especificação de acordo com lista pré-definida existente } \\
\text { no SEI. }\end{array}$ \\
\hline Especificação & Campo aberto descritivo \\
\hline Classificação por Assuntos & $\begin{array}{l}\text { Preenchimento de acordo com a tabela de classificação } \\
\text { disponível no SEI. É possível informar mais de um } \\
\text { assunto para cada processo. }\end{array}$ \\
\hline Interessado(s) & $\begin{array}{l}\text { Identificação da pessoa física ou jurídica diretamente } \\
\text { interessada no andamento do processo. Pode ser } \\
\text { informada mais de uma pessoa. }\end{array}$ \\
\hline \multicolumn{2}{|c|}{ INFORMAÇÕES COMPLEMENTARES } \\
\hline MP & $\begin{array}{l}\text { Se a solicitação é do Ministério Público Federal ou } \\
\text { Estadual. }\end{array}$ \\
\hline $\begin{array}{l}\text { Processo aberto com } \\
\text { documento do MP? }\end{array}$ & Se o documento do MP deu origem ao processo. \\
\hline Processo MP & Identificação do processo do MP. \\
\hline Solicitação & Descrição do que foi solicitado pelo MP. \\
\hline Relac. a processo do lbama? & $\begin{array}{l}\text { Se há relação com processo anteriormente aberto pelo } \\
\text { lbama (de fiscalização ou licenciamento, por exemplo). }\end{array}$ \\
\hline Município & Município onde se encontra o fato sob análise. \\
\hline Respondido & Se o documento do MP foi ou não respondido pelo Ibama. \\
\hline Assunto/ Observação & Informações complementares sobre o processo. \\
\hline
\end{tabular}

Fonte: Elaboração própria, 2019.

25 Observa-se que na relação não constam todos os processos que tiveram requisições do MP no período, e sim aqueles que tramitaram no Ibama/PE após a implantação do SEI e, por isso, estão disponíveis no sistema. 
Na Figura 15, pode-se observar um exemplo de como são apresentados os metadados dos processos no SEl:

Figura 15 - Exemplo de metadados de processo no SEI.

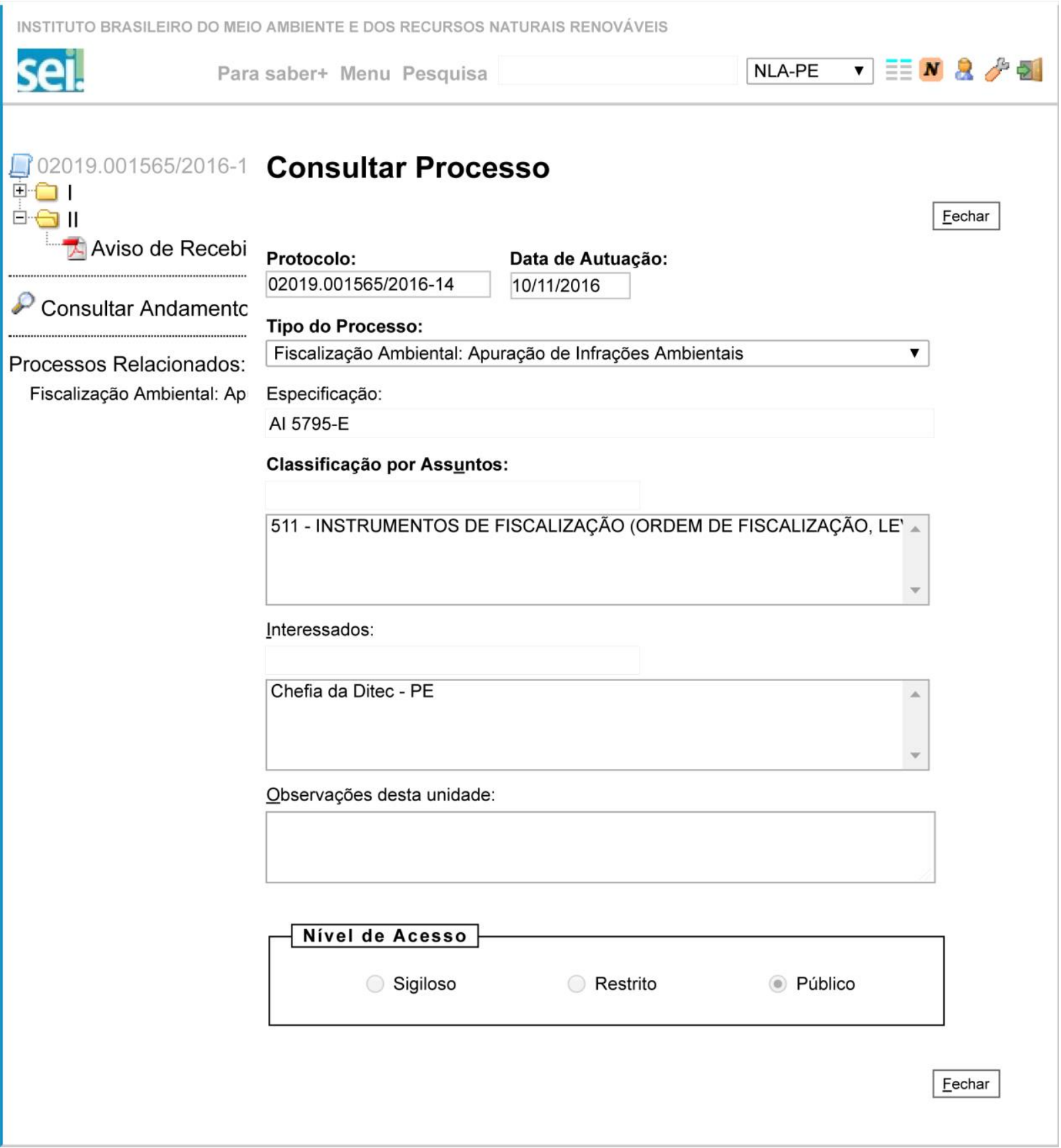

Fonte: Elaboração própria (2019), a partir de consulta ao SEI.

Aplicando-se aos dados da planilha do Apêndice $\mathbf{C}$ as técnicas de visualização da informação, foram gerados os gráficos da Figuras 16 a 20, conforme vê-se a seguir: 
Figura 16 - Quantitativo por tipo de processo.

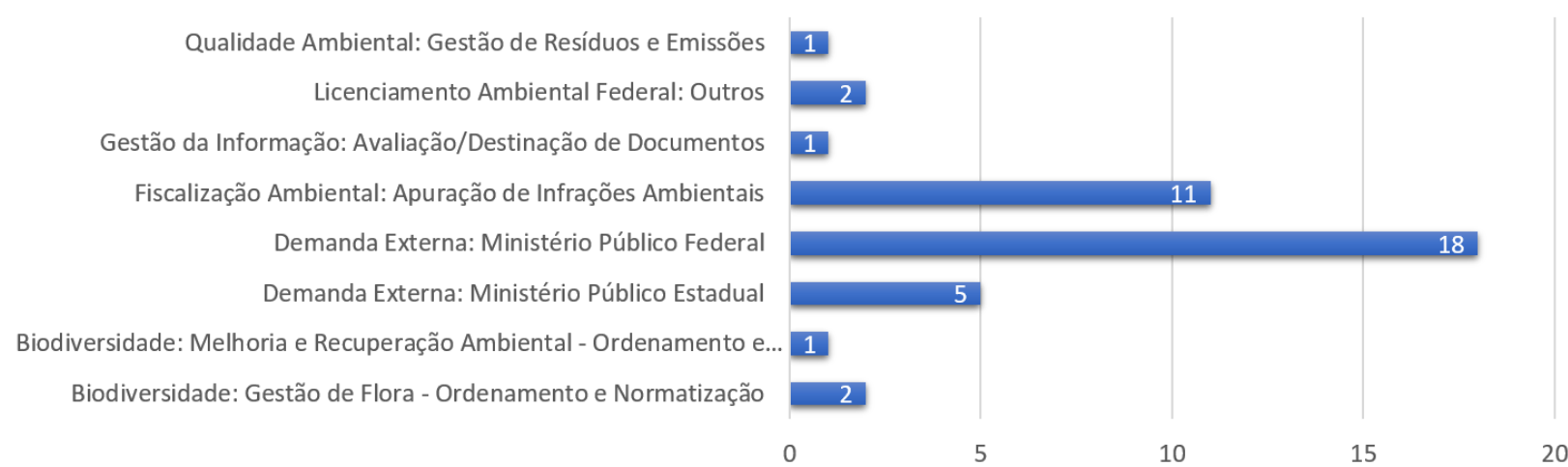

Fonte: Elaboração própria, 2019.

Figura 17 - Quantitativo de processos por assunto.

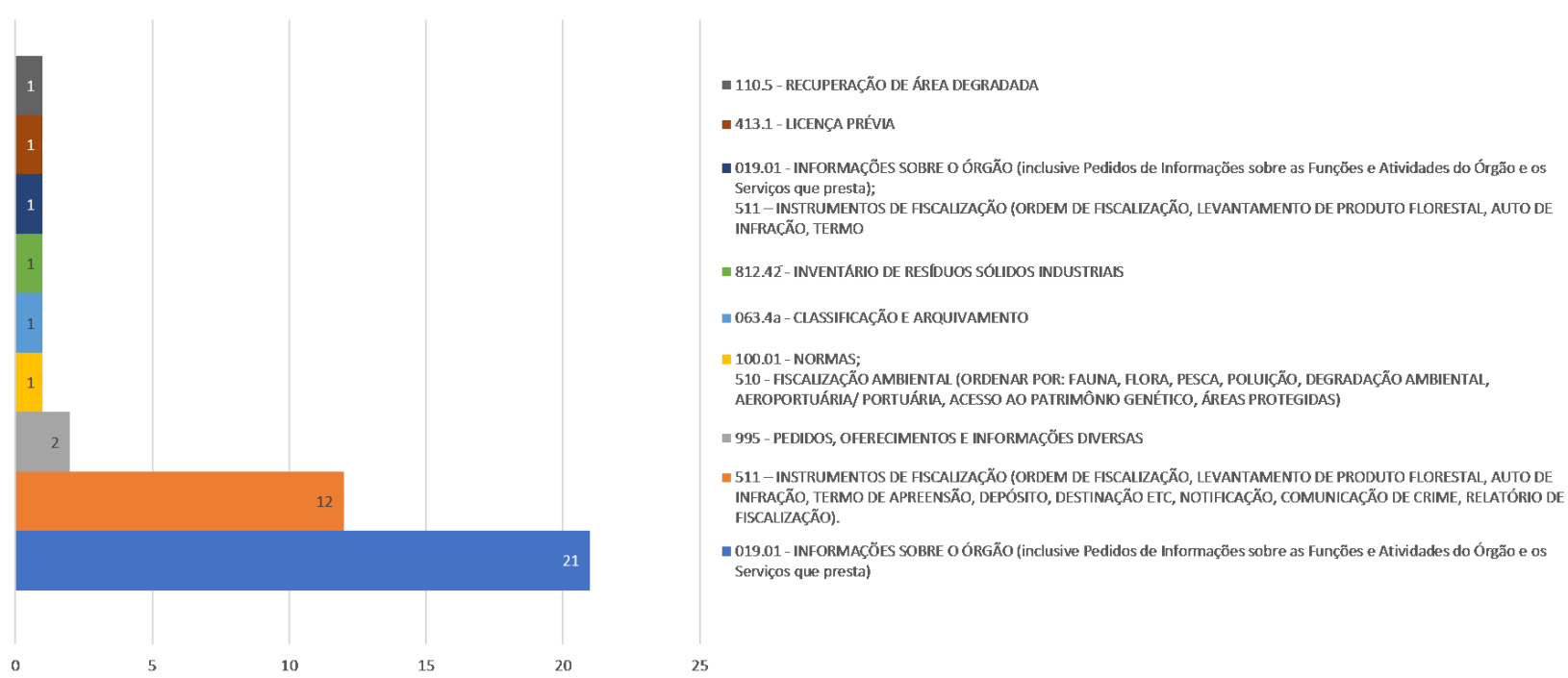

Fonte: Elaboração própria, 2019. 
Figura 18 - Percentual de demandas por esfera do Ministério Público.

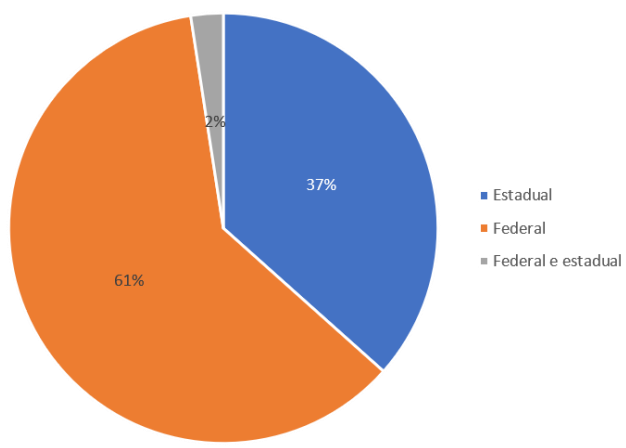

Fonte: Elaboração própria, 2019.

Figura 19 - Relação entre tipo de processo e MP solicitante.

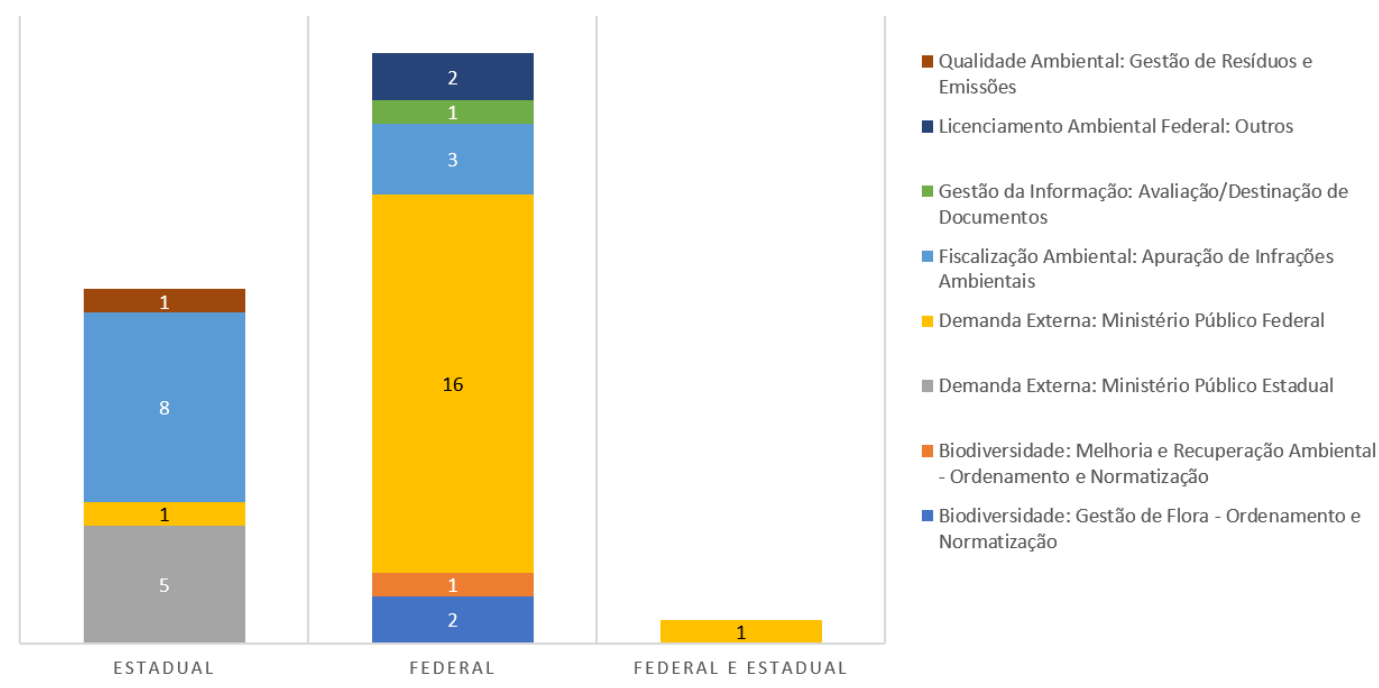

Fonte: Elaboração própria, 2019.

Figura 20 - Percentual de demandas relacionadas a processos do Ibama.

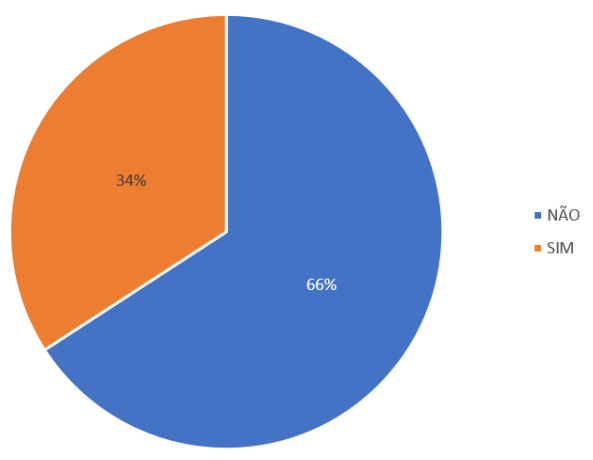

Fonte: Elaboração própria, 2019. 
Ressalta-se, entretanto, que os dados dos campos listados no Quadro 6 como "informações complementares" não foram simplesmente copiados do sistema, mas sim obtidos a partir da leitura dos processos sob análise. Isso significa que não há a possibilidade de automatização dos dados para obtenção de gráficos ou estatísticas, uma vez que há a necessidade da interpretação humana para a obtenção das informações. Isso significa dizer que, dos gráficos apresentados nas Figuras 16 a 20, somente os das Figuras 16 e 17 poderiam ser gerados automaticamente com os dados disponíveis no sistema.

Além disso, destaca-se que a falta de padronização na inserção dos metadados dificulta a identificação de padrões que possibilitem a interpretação visual dos dados. Por exemplo, observe-se o quadro abaixo, que contém um extrato de alguns processos constantes da planilha do Apêndice $\mathbf{C}$, apresentando somente os campos dos metadados:

Quadro 7 - Extrato da planilha do Apêndice C.

\begin{tabular}{|c|c|c|c|c|c|}
\hline Processo no & $\begin{array}{l}\text { Data de } \\
\text { Autua- } \\
\text { ção }\end{array}$ & $\begin{array}{l}\text { Tipo do } \\
\text { Processo }\end{array}$ & Especificação & $\begin{array}{l}\text { Classific. } \\
\text { por } \\
\text { Assun- } \\
\text { tos }\end{array}$ & Interessado(s) \\
\hline $\begin{array}{l}02019.000286 / 2 \\
016-25\end{array}$ & $\begin{array}{l}01 / 03 / 20 \\
16\end{array}$ & $\begin{array}{l}\text { Biodiversidade: } \\
\text { Gestão de Flora } \\
\text { - Ordenamento e } \\
\text { Normatização }\end{array}$ & $\begin{array}{l}\text { MINISTÉRIO PÚBLICO } \\
\text { FEDERAL DE } \\
\text { PERNAMBUCO }\end{array}$ & $\begin{array}{l}100.01 \\
510\end{array}$ & $\begin{array}{l}\text { Ministério Público } \\
\text { Federal em } \\
\text { Pernambuco }\end{array}$ \\
\hline $\begin{array}{l}02019.000987 / 2 \\
017-45\end{array}$ & $\begin{array}{l}06 / 04 / 20 \\
17\end{array}$ & $\begin{array}{l}\text { Demanda } \\
\text { Externa: } \\
\text { Ministério } \\
\text { Público Federal }\end{array}$ & - & 511 & $\begin{array}{l}\text { Ministério Público } \\
\text { Federal (MPF) }\end{array}$ \\
\hline $\begin{array}{l}02019.100353 / 2 \\
017-91\end{array}$ & $\begin{array}{l}30 / 05 / 20 \\
17\end{array}$ & $\begin{array}{l}\text { Licenciamento } \\
\text { Ambiental } \\
\text { Federal: Outros }\end{array}$ & $\begin{array}{l}\text { Ministério Público } \\
\text { Federal }\end{array}$ & 511 & $\begin{array}{l}\text { MINISTÉRIO } \\
\text { PÚBLICO } \\
\text { FEDERAL }\end{array}$ \\
\hline $\begin{array}{l}02019.100835 / 2 \\
017-41\end{array}$ & $\begin{array}{l}05 / 07 / 20 \\
17\end{array}$ & $\begin{array}{l}\text { Demanda } \\
\text { Externa: } \\
\text { Ministério } \\
\text { Público Federal }\end{array}$ & $\begin{array}{l}\text { INQUÉRITO CIVIL № } \\
1.26001 .000264 / 2015- \\
86\end{array}$ & 019.01 & $\begin{array}{l}\text { PROCURADORIA } \\
\text { DA REPÚBLICA } \\
\text { POLO } \\
\text { PETROLINA/JUAZ } \\
\text { EIRO }\end{array}$ \\
\hline $\begin{array}{l}02019.100836 / 2 \\
017-96\end{array}$ & $\begin{array}{l}05 / 07 / 20 \\
17\end{array}$ & $\begin{array}{l}\text { Demanda } \\
\text { Externa: } \\
\text { Ministério } \\
\text { Público Federal }\end{array}$ & $\begin{array}{l}\text { INQUERITO CIVIL № } \\
1.26001000282 / 2014- \\
87\end{array}$ & 019.01 & $\begin{array}{l}\text { MPF-Procuradoria } \\
\text { da Republica Polo } \\
\text { Petrolina/Juazeiro }\end{array}$ \\
\hline
\end{tabular}

Fonte: Elaboração própria, 2019.

No quadro acima, vê-se que o mesmo interessado (Ministério Público Federal) é registrado de diversas formas. Para um humano, é fácil identificar que se trata da mesma instituição, mas, para a máquina, representam registros diferentes, o que 
dificulta imensamente o processamento automatizado. Atente-se ao fato de que a amostragem deste estudo trabalha com um universo restrito a 41 processos, em que é possível verificar a adequação de cada dado registrado, o que seria inviável na análise de uma grande quantidade de processos.

Além da falta de padronização, destaca-se também a frequente irregularidade no preenchimento dos campos. O processo descrito na Figura 15, por exemplo, refere-se a um processo de Auto de Infração, identificado no campo "Especificação". No entanto, é vê-se que o campo de "interessado" foi informado como "Chefia da Ditec - PE”, e não com o nome do autuado, como seria o indicado e era a prática comum antes da implantação do SEI. Observando-se os dados constantes no mesmo campo da planilha do Apêndice $\mathbf{C}$, constata-se que esse não é um caso isolado e falhas são facilmente verificadas nos outros campos de metadados dos processos. Outro exemplo é o registro do processo № 02019.103069/2017-77, cujo campo "tipo de processo" está identificado como "Demanda Externa: Ministério Público Federal", enquanto no campo "Interessado" consta "MINISTERIO PUBLICO DO ESTADO DE PERNAMBUCO (MP/PE)" e, consultando os documentos do processo, constata-se que se trata mesmo do MPPE.

Da mesma forma, evidenciam-se de pronto diversos erros no cadastro dos processos no sistema. Não há, por exemplo, identificação quanto ao tipo de informação que deve constar no campo "especificação", sendo este por vezes preenchido com os dados do interessado. Tantos outros equívocos são observados no detalhamento de cada documento que integra os processos e a frequência com que tais problemas se repetem demonstra que não há confiabilidade nos dados que são inseridos no sistema.

Outro problema frequente identificado durante a pesquisa foi que a chegada de novos documentos sempre gera a abertura de novos processos, que nem sempre são incorporados aos originais. Assim, muitas vezes processos com o mesmo assunto tomam caminhos distintos, sendo tramitados por diferentes setores e analisados de forma distinta.

Contudo, ressalta-se que não cabe a este trabalho enumerar todos os erros observados, mas sim analisar quais as implicações dessas falhas na gestão da informação armazenada pelo Ibama. De fato, a conclusão mais importante que se pode tirar dessa análise é que a falta de padronização e de confiabilidade nos dados 
que são inseridos no sistema representam uma grave limitação para a adequada gestão da informação no Instituto.

\subsubsection{Indexação pelo usuário e recuperação da informação}

Os processos e documentos são gerados no SEI pelos próprios usuários do sistema (ou seja, qualquer servidor da organização), sendo eles responsáveis não só pela produção, mas também pelo registro dos metadados que descrevem tais documentos.

Neste ponto, é inevitável lembrar das ideias de Silva e Smit (2009) acerca das dificuldades apresentadas pelos sistemas baseados na indexação pelo usuário não especializado, que interferem diretamente no processo de recuperação da informação. Tal como defendido por e Pavão et al (2015), não há como garantir que o documento será recuperado, assim como a interoperabilidade do sistema e a mineração de informações, se não houver um trabalho anterior que garanta a qualidade dos metadados inseridos no sistema.

No trabalho diário de produção de documentos, observa-se que o usuário não compreende a atividade de inserção de metadados como obrigação sua, ou mesmo entenda a importância de tal ação. Rotineiramente, o usuário do sistema se limitará a preencher somente os campos obrigatórios dos metadados, de modo a não perder nessa atividade o tempo que deve dedicar à produção do documento em si. A questão que se coloca aqui é se tal atividade deve ser cobrada do usuário não especializado ou se o sistema deve ser desenvolvido para facilitar tal ação.

Aparentemente, há uma excessiva confiança de que todo o conteúdo pode ser recuperado com a pesquisa textual, já que, a rigor, todos os documentos inseridos no SEI ou são natos digitais ou foram digitalizados com OCR. No entanto, para quem tem o mínimo de noção dos conceitos de indexação e catalogação, é evidente que a busca textual sintática não abrange todo o conteúdo semântico do documento - o sistema não tem como entender, por exemplo, que "carcinicultura" é o mesmo que "criação de camarão". Além disso, o sistema só consegue processar adequadamente a busca textual (ainda que com um alto índice de revocação) quando se trata dos documentos produzidos no próprio sistema. Para os documentos externos, ou seja, inseridos após digitalização, a falta de precisão do OCR compromete seriamente essa operação, como se pode observar na Figura 7. O problema é mais recorrente nos casos de 
documentos impressos com baixa qualidade ou em papel reciclado, que dificulta a leitura pelo equipamento. Por exemplo, o "Ofício no 1889/2017/GAB/MPF/PRM/GAR 2ํㅡ" OF" é lido como "Ofreion2 1889/2017/GA8/MPF/PRM/GAR- 22 OF" (processo oㅜ 02019.102339/2017-22). Apesar de parecer pequena a diferença, falhas desse tipo inviabilizam completamente a identificação do documento pela ferramenta de busca textual.

No estudo de caso em tela, é importante destacar que os servidores efetivos e terceirizados do lbama foram treinados antes da implantação do SEI basicamente pelo curso virtual promovido pela Escola Nacional de Administração Pública (ENAP), sem tutoria. Além disso, foram realizadas videoconferências para treinamento específico dos setores de protocolo e treinamento presencial de dois servidores para cada Superintendência, para que figurassem como pontos focais durante a implantação do sistema. De forma geral, todos os treinamentos focaram nas ações básicas, familiarização com a interface e operações mais frequentes realizadas no SEI.

Ressalta-se que o Manual do Usuário do SEI, publicado pelo Portal do Software Público Brasileiro ${ }^{26}$, destaca a importância da padronização de procedimentos pelos órgãos que adotam o sistema, alegando que, por ser uma ferramenta bastante flexível, - SEI proporciona formas variadas de utilização de suas funcionalidades. É recomendado que cada instituição estabeleça normas e procedimentos para garantir a segurança, o acesso e a organização do trabalho realizado no sistema, assim como modelos de documentos, tabelas de temporalidade metodologias e nomenclaturas.

A Portaria Ibama nº 09, de 24/04/2017, que estabelece os procedimentos para uso do SEI no âmbito do lbama, orienta sobre questões gerais de operação do sistema, necessários à sua implantação, mas não chega a detalhar sobre a forma de preenchimento dos campos de metadados:

Art. 20 Para a criação de um processo eletrônico devem ser inseridos no SEl-Ibama dados que permitam sua eficiente localização e controle, mediante o preenchimento dos campos próprios do sistema. $[\ldots]$

Art. 33 Todos os processos do SEl-lbama serão classificados com base no Código de Classificação das Atividades-meio da Administração Pública do Conselho Nacional de Arquivos (CONARQ) e Plano de Classificação de Documentos da Área Fim do lbama de

26 Disponível em: <https://softwarepublico.gov.br/social/articles/0004/9746/sei-doc-usuario.pdts. Acesso em 14.dez.2018. 
forma automática conforme o tipo de processo escolhido no SEIIbama. (Portaria Ibama no 09, de 24/04/2017).

Em relação à classificação por assuntos, a lista utilizada atualmente no lbama e constante do SEI relaciona 1123 assuntos. Entretanto, consta do processo no 02000.019858/2018-19 o planejamento da contratação de serviços técnicos para tratamento do acervo arquivístico do lbama-Sede, incluindo, entre outros, a aplicação do plano de classificação documental e a elaboração de tabela de temporalidade para o órgão. Isso porque a tabela de assuntos das atividades-fim até então utilizada pelo Ibama não foi aprovada pelo Arquivo Nacional e, portanto, é adotada provisoriamente, sendo necessária sua revisão e publicação para que possa ter efeito legal na preservação e descarte de documentos. No entanto, por força do Ofício Circular $\mathrm{N}^{\circ}$ 841-MMA, de 29/11/2018, foram suspensas todas as licitações para contratações de novos serviços pelo lbama, até que sejam definidas as novas diretrizes pelo novo governo. Desse modo, essa questão permanece pendente de solução.

Destaca-se, ainda, que para a classificação de "nível de acesso" (ver Figura 15) dos processos, a orientação é de que todos os processos cadastrados no SEI, a menos os que possuem claras restrições legais, sejam classificados como públicos. No entanto, tal classificação implica somente na possibilidade de visualização do conteúdo em todas as unidades do órgão, não havendo publicidade automática para o público externo. Os pedidos de acesso externo aos processos são analisados caso a caso.

\subsection{IBAMA - CONTEXTO, SISTEMAS E GESTÃO DA INFORMAÇÃO}

Tal como defendido por Johnson (2009), Chatman (2001) e Presser e González (2017), entre outros teóricos citados no capítulo 2, não é possível compreender o comportamento humano em informação sem considerar o contexto em que está inserido o objeto de análise. De fato, a despeito das críticas acima acerca das deficiências na padronização de procedimentos e na orientação de uso do SEI - o que se repete também com outros sistemas - a realidade é que o Ibama enfrenta uma séria deficiência no que diz respeito à carência de servidores para as ações de planejamento, análise e execução, tanto na área meio, quanto na atividades-fim.

Historicamente relegado a segundo plano na estrutura da Administração Pública, não há uma perspectiva favorável no contexto sócio-político para valorização 
do lbama a médio prazo. Isso porque, sobretudo na visão de setores mais conservadores da sociedade, a defesa ambiental é tida como um empecilho ao crescimento econômico. Essa realidade reflete perfeitamente o pensamento de Jonhson (2009) acerca das motivações para a negação das informações, quando há uma recusa clara a tomar conhecimento de evidências científicas que contrariam seus próprios interesses. A questão gira, invariavelmente, em torno da discussão de quem paga o custo das ações predatórias de pequenos grupos produtores, mas com forte poder econômico: os lucros para poucos e o prejuízo repartido entre toda a população.

Países com maior índice de desenvolvimento humano, no entanto, já compreenderam que a preservação ambiental não só é essencial para a qualidade de vida da população, como também representa economia do controle de temperatura das cidades, conservação dos recursos hídricos, controle de erosão, só para citar alguns benefícios. Essa visão entende que o meio ambiente e as consequências de sua depredação extrapolam os limites geográficos e, por vezes, o aporte financeiro desses países, além dos acordos climáticos internacionais e da pressão de mercados como a União Europeia - que exigem certificações ambientais para a aquisição de produtos - é que garantem a sobrevivência (ou a própria existência) de instituições ambientais como o Ibama.

Por outro lado, a interferência política, sobretudo em relação à indicação dos ocupantes de cargos de direção, influencia diretamente na capacidade de gestão na continuidade das ações do lbama. Além da grande rotatividade de presidentes ${ }^{27}$, não é raro que as Superintendências nos estados tenham seus cargos negociados com as bancadas de apoio no Congresso Nacional, sendo ocupados frequentemente por pessoas sem qualquer experiência na área ambiental ou da administração pública. Houve casos recentes, inclusive, de superintendentes com histórico de autuação por crime ambiental ou com mandato eletivo cassado, que, evidentemente, deveriam ser impedidos de assumir qualquer cargo comissionado. Nesse contexto, a Supes/PE é frequentemente citada como "sortuda" entre os servidores de outros estados, por ter tido, nos últimos dez anos, apenas servidores de carreira ocupando o cargo de Superintendente.

${ }^{27}$ Até o final de 2018, o lbama teve 24 presidentes, o que dá uma média de menos de quinze meses de mandato para cada um. 
Sem dúvida, os recursos financeiros são sempre bastante limitados, e dificilmente essa realidade mudará tão cedo, pois é algo comum a todo o Poder Executivo. Mas outro recurso, o humano, tem se tornado ainda mais escasso. De fato, não é possível tratar da questão da qualidade do serviço público prestado à população sem mencionar ao déficit de pessoal que se agrava a cada ano. Sobre isso, o Relatório Anual de Atividades de Auditoria Interna do Ibama relativo ao exercício de 2017 atesta que "[...] o quantitativo de servidores efetivos é insuficiente para um desempenho adequado das atividades-meio e fim do Instituto, especialmente nas unidades descentralizadas, onde há uma maior carência de pessoal." (IBAMA, 2018a, p. 10). Prestes a completar trinta anos de existência, o lbama vem perdendo, com as aposentadorias dos servidores mais antigos, uma expressiva parcela do seu quadro de servidores, que não está sendo reposta por concurso público. De acordo com a análise da Auditoria, a insuficiência de recursos humanos se apresenta como uma das grandes fragilidades do Ibama, sendo que algumas unidades "[...] estão na iminência de perder algo em torno de $50 \%$ de sua força de trabalho dentro dos próximos cinco anos [...]" (ibid., p. 10), o que tem acendido o alerta do Instituto na preocupação de manter sua capacidade operacional.

Uma das consequências mais graves nessa defasagem no número de pessoal nas unidades é o risco de se prestar um Serviço Público de forma inadequada e ineficiente, a exemplo do grande número de prescrições de débitos decorrentes de auto de infração emitidos pela Fiscalização Federal, cobranças intempestivas da taxa de Cadastro Técnico Federal, bem como fragilidades na gestão de contratos administrativos celebrados pelo Instituto. (ibid., p. 11).

Da mesma forma, a Coordenação-Geral de Tecnologia da Informação (CGTI) registra, no Plano Diretor de Tecnologia da Informação e Comunicações (PDTIC), que seu quadro de pessoal é reduzido e insuficiente para gerir a estrutura de TIC do órgão e, principalmente, acompanhar adequadamente os contratos de fábrica de software, que fazem o desenvolvimento e manutenção dos sistemas informatizados do Ibama.

"[...] Se houvesse um quadro de servidores adequado, os riscos e problemas de sistemas seriam mitigados, pois os mesmos absorveriam o conhecimento dos sistemas que são desenvolvidos e manutenidos pelas empresas contratadas, evitando-se a descontinuidade na prestação dos serviços de sistemas de informação." (IBAMA, 2018, p. 23).

Como já citado anteriormente, o lbama trabalha com uma grande quantidade de sistemas informatizados (ver Anexo A). Tais sistemas relacionam-se diretamente 
às atividades desenvolvidas pelo Instituto, estando vinculados também a diversos serviços prestados à população, os quais estão descritos na Carta de Serviços ao Cidadão (IBAMA, 2014), que é atualizada periodicamente e publicada no site da instituição (www.ibama.gov.br). O acesso do público externo de todos os serviços online é feito através do Cadastro Técnico Federal de Atividades e Instrumentos de Defesa Ambiental (CTF/AIDA) ou do Cadastro Técnico Federal de Atividades Potencialmente Poluidoras e/ou Utilizadoras de Recursos Ambientais (CTF/APP).

No entanto, ainda que o usuário externo acesse os serviços on-line por uma única entrada, a realidade é que poucos sistemas utilizados pelo lbama são integrados entre si. Isso, sem dúvida, é um grande complicador na gestão da informação, uma vez que os servidores precisam de diferentes acessos para reunir todas as informações de um cidadão ou empreendimento. Frequentemente são necessárias, inclusive, que as consultas sejam efetuadas por diferentes agentes públicos, pois cada sistema exige um perfil de acesso próprio, variando bastante entre os funcionários. Além disso, muitas informações não estão disponíveis como dados nos sistemas, e sim registradas em processos administrativos no SEI, em documentos textuais, e, por isso, requerem leituras mais demoradas e apresentam restrições para a automatização do processamento.

Em tese, seria muito mais simples refazer os sistemas, observando-se as necessidades atuais, do que os corrigir. No entanto, essa alternativa é inviável pelo fato de que não se pode paralisar as atividades da instituição, sobretudo os serviços prestados ao público externo. Nesse cenário, resta ao Instituto buscar a melhor forma de incorporar novas tecnologias e adaptar-se às novas exigências legais e da sociedade.

A despeito dessa realidade, o Ibama vem trabalhando para modernizar seus sistemas e, principalmente, integrar as informações. Um bom exemplo disso é o Sistema Nacional de Controle da Origem dos Produtos Florestais (Sinaflor), que tem por objetivo agregar os dados de todos os sistemas dos órgãos do Sisnama de controle de produtos e subprodutos florestais, tais como o Documento de Origem Florestal (DOF), o Ato Declaratório Ambiental (ADA), o Cadastro Ambiental Rural (CAR) e o Cadastro Técnico Federal (CTF), além de outros sistemas dos entes federados. Previsto desde a edição da Lei no 12.651/2012 (Lei de Proteção da Vegetação Nativa), o Sinaflor foi lançado oficialmente em 2017 e ainda está em fase de implantação gradual em todo o país. Quando estiver em pleno funcionamento, o 
sistema deverá permitir a fácil distinção entre o desmate em áreas autorizadas pelos órgãos ambientais e o desmatamento ilegal, aprimorando o trabalho fiscalizatório, a certificação de produtos florestais e de atividades, compreendendo toda a cadeia produtiva de madeira, carvão e derivados, além de facilitar o controle da população sobre tais atividades. Antes do Sinaflor - e ainda atualmente na maior parte do país apenas o transporte e a comercialização de produtos florestais eram controlados por sistema informatizado, sendo que a etapa anterior, de produção, ficava somente registrada em processos administrativos isolados.

Outra questão de grande relevância para o tratamento da informação no âmbito da Administração Pública diz respeito à segurança versus a publicidade da informação. Importa destacar que a Lei de Acesso à Informação (LAI) prevê a responsabilização tanto dos agentes públicos que negarem o acesso à informação, quanto daqueles que permitirem o acesso a informação sigilosa ou pessoal (art. 32 da Lei no 12.527/2011). No entanto, não há clareza para os servidores quanto a que tipos de informação podem ou não ser disponibilizadas ao acesso público.

Embora a LAI defina a publicidade como regra e o sigilo como exceção invertendo a lógica excessivamente custodialista que até então imperava no serviço público -, deve-se observar que o lbama trabalha frequentemente com informações confidenciais ou sensíveis, tais como: as atividades de inteligência, que investigam crimes ambientais; processos de licenciamento ambiental, que contém projetos de novos empreendimentos, protegidos por propriedade industrial; auditorias do Cadastro Técnico Federal, que podem ter declarações de imposto de renda de empresas; entre tantos outros. Nesse contexto, o Ibama publicou, em 2012, sua Política de Segurança da Informação, Informática e Comunicações (Posic; Portaria no 9, de 5 de junho de 2012), a qual é bastante enfática nas questões de proteção das informações geridas pelo lbama. No tocante ao acesso, no entanto, a Posic traz apenas diretrizes gerais, determinado a observância da legislação específica para a classificação de restrição das informações:

Art. $20^{\circ}$ A classificação e o tratamento da informação observarão os seguintes requisitos e critérios:

I - o valor, requisitos legais, sensibilidade e criticidade da informação para o Ibama;

II - conjunto apropriado de procedimentos para rotulação e tratamento da informação que será definido e implementado de acordo com o critério de classificação adotado pelo Ibama; 
Art. $21^{\circ}$ Toda informação criada, manuseada, armazenada, transportada ou descartada do Ibama será classificada toda quanto aos aspectos de confidencialidade, integridade e disponibilidade, de forma explícita ou implícita;

Art. $22^{\circ}$ A classificação e tratamento de informação serão:

I - norteadas pela legislação específica que disponha sobre a salvaguarda de dados, informações, documentos e materiais sigilosos de interesse da segurança da sociedade e do Estado, no âmbito da Administração Pública Federal (APF);

II - implementados e mantidos, em conformidade com a legislação vigente, visando a estabelecer os controles de segurança necessários a cada informação custodiada ou de propriedade do Ibama, ao longo do seu ciclo de vida; e

III - realizados de acordo com norma complementar específica sobre a matéria. (Portaria Ibama no 9/2012).

Na análise da Auditoria Interna do Ibama, há um grande desconhecimento dos servidores sobre as determinações e mesmo sobre a existência do Posic (IBAMA, 2018a), o que representa uma fragilidade em termos de segurança da informação que o Instituto detém. No entanto, observa-se que a partir da edição da Posic, o Ibama passou a ter um maior rigor na concessão de acesso aos sistemas corporativos, além de outras medidas protetivas em relação aos sistemas informatizados. Entretanto, o acesso à informação pelo público externo ainda é irregular, mesmo que atualmente seja facilitado pelo Serviço de Informações ao Cidadão (SIC) ${ }^{28}$. Isso porque a quantidade excessiva de normas e a falta de clareza quanto à classificação de restrição das informações traz grande insegurança aos agentes públicos, reforçando a ideia da necessidade de controle e dificultando o compartilhamento e a publicidade das informações armazenadas pelo órgão.

Por outro lado, o Ibama lançou, em 2017, seu primeiro Plano de Dados Abertos, com vigência 2018-2019 e com o objetivo de:

Promover a abertura de dados do Ibama, zelando pelos princípios da publicidade, transparência e eficiência, visando ao aumento da disseminação de dados contendo informações de interesse público, bem como à melhoria da qualidade dos dados disponibilizados, de forma a contribuir para a tomada de decisão dos gestores públicos e incentivar o controle social. (IBAMA, 2017, p. 14).

Essa iniciativa vincula-se diretamente às diretrizes da LAI, como também à Política de Governança Digital (Decreto n 8.638/2016) e à Política de Dados Abertos

\footnotetext{
${ }^{28}$ Sob a coordenação da Controladoria Geral da União (CGU), todos os órgãos do Executivo Federal implantaram um SIC em sua estrutura, para atendimento às demandas da Lei de Acesso à Informação (LAI). No Ibama, o SIC está vinculado à Auditoria Interna.
} 
do Executivo Federal (Decreto $n^{\circ}$ 8.777/2016), além da Lei $n^{\circ}$ 10.650/2003, que "dispõe sobre o acesso público aos dados e informações existentes nos órgãos e entidades integrantes do Sisnama". O conceito de dados abertos e seus requisitos estão expressos abaixo:

Os dados abertos governamentais são regidos por três leis propostas pelo ativista de governo aberto chamado David Eaves:

- Se o dado não pode ser encontrado e indexado na Web, ele não existe;

- Se o dado não estiver aberto e disponível em formato compreensível por máquina, ele não pode ser reaproveitado;

- Se algum dispositivo legal não permitir sua replicação, ele não é útil. Considerando essas leis como premissas, oito princípios dos dados abertos governamentais foram definidos pelo Open Government Data: 1 - Completos: dados públicos são dados que não estão sujeitos a limitações válidas de privacidade, segurança ou controle de acesso, reguladas por estatutos;

2 - Primários: os dados são apresentados tais como os coletados na fonte, com o maior nível possível de granularidade e sem agregação ou modificação;

3 - Atuais: os dados são disponibilizados o quão rapidamente seja necessário para preservar o seu valor;

4 - Acessíveis: são disponibilizados para o público amplo e para os propósitos mais variados possíveis;

5 - Processáveis por máquina: são razoavelmente estruturados para possibilitar o seu processamento automatizado;

6 - Acesso não discriminatório: estão disponíveis a todos, sem que seja necessária identificação ou registro;

7 - Formatos não proprietários: estão disponíveis em um formato sobre o qual nenhum ente detenha controle exclusivo;

8 - Livres de licenças: não estão sujeitos a regulações de direitos autorais, marcas, patentes ou segredo industrial. Restrições razoáveis de privacidade, segurança e controle de acesso podem ser permitidas na forma regulada por estatutos.

No contexto deste plano de dados abertos, considera-se como dado aberto aquele que atende às três leis e aos oito princípios citados acima. (IBAMA, 2017, p. 22).

A publicação de dados abertos ${ }^{29}$ é, sem dúvida, um grande passo para o fortalecimento da transparência da instituição. No entanto, essa abertura exige um cuidado ainda maior com a qualidade da informação disponibilizada à sociedade, uma vez que não passarão por qualquer filtro antes de seu acesso, ou seja, não será analisada por um servidor antes da entrega. Assim, mostra-se ainda mais importante

29 Os dados abertos do lbama estão sendo gradativamente disponibilizados em seu site, no endereço: http://dadosabertos.ibama.gov.br/organization/instituto-brasileiro-do-meio-ambiente-e-dos-recursosnaturais-renovaveis. Acesso em 28/01/2019. 
que todos os campos dos documentos produzidos e seus metadados estejam corretamente preenchidos, sob pena de comprometer a integridade dos dados compartilhados ou mesmo de incorrer no vazamento de dados sensíveis - como, por exemplo, quando dados pessoais são inseridos em outros campos indevidamente.

Ressalta-se que os sistemas, de forma geral, não trazem manuais de utilização ou, quando o fazem, eles não apresentam grande detalhamento e raramente acompanham as evoluções implantadas no respectivo sistema. Na prática, o usuário é treinado superficialmente nos sistemas novos ou aprende na prática e com colegas veteranos a operar os sistemas antigos - por vezes apenas repetindo operações básicas (e até mesmo os erros), sem, no entanto, compreender a lógica e a totalidade do sistema.

\subsection{PROPOSTAS PARA A GESTÃO DA INFORMAÇÃO NO IBAMA}

A partir das observações relatadas anteriormente, destacamos aqui questões que o Ibama enfrenta e que representam limitações e desafios para uma adequada gestão da informação no Instituto:

a. Baixa integração dos sistemas de informação;

b. Limitação das possibilidades de relatórios emitidos pelos sistemas;

c. Pouca confiabilidade na entrada de dados;

d. Falta de padronização para inserção de dados nos sistemas;

e. Falta de continuidade da gestão (interferência política);

f. Insegurança jurídica em relação à classificação de acesso à informação;

g. Carência de servidores para execução de atividades de planejamento, análise e operacionais;

h. Cobrança da sociedade - transparência e agilidade nas respostas;

i. Mudança de cultura - do custodial e patrimonialista para o pós-custodialista, ou seja, entender a informação como direito da sociedade.

Evidentemente, algumas questões estão além do alcance deste trabalho e, portanto, serão apresentadas apenas diretrizes no intuito de aprimorar gestão da informação no lbama, de modo que possa otimizar os trabalhos técnicos diários; subsidiar a elaboração de normas para uniformização das análises dos processos (como, por exemplo, processos de licenciamento ou julgamento de autos de infração); 
como também embasar o desenvolvimento das políticas públicas relativas à gestão ambiental.

Idealmente, os sistemas de informação deveriam ser projetados (ou atualizados) observando a necessidade de geração de relatórios gerenciais não somente sintéticos, como planilhas de dados brutos, mas também prevendo a possibilidade de geração de gráficos com interação do usuário. No entanto, visto que bastante restritos os recursos (financeiros, humanos e de tempo) para o desenvolvimento de sistemas, é preferível que os sistemas possibilitem a geração de relatórios customizáveis, ou seja, que dê ao usuário a opção de escolha sobre quais campos de dados irá utilizar para emissão de relatórios. Ao mesmo tempo em que tira do desenvolvedor a obrigatoriedade de prever todas as análises possíveis - o que é algo impraticável -, isso dá ao usuário a liberdade para interagir com os dados armazenados, além de tornar o sistema mais adaptável a novas análises.

Observa-se, inclusive, que a maior parte dos atuais softwares de edição de textos e de planilhas (como o Microsoft Office) já oferecem ferramentas para geração de gráficos a partir dos dados de listas, tabelas e planilhas - tais como os gráficos apresentados neste trabalho - e podem ser utilizados para possibilitar esse tipo de análise. No entanto, é essencial que os sistemas permitam a emissão dos relatórios em formato editável, de modo a tornar possível não só sua manipulação gráfica, como também o desenvolvimento de novos serviços de informação.

No tocante aos sistemas informatizados, cabe destacar a necessidade de melhoria de suas interfaces, com ênfase na usabilidade. É importante que os formulários tragam campos autoexplicativos, com menus de auxílio na própria tela, além de manuais claros e detalhados sobre a utilização dos sistemas. Tal como apontado por Silva e Smit (2009), é necessário aperfeiçoar as mediações dos sistemas com os usuários, com a finalidade de implantar mecanismos de controle alinhados com os princípios de organização da informação, de modo que sejam minimizadas as possibilidades de erros na entrada de dados.

Especificamente acerca da inserção de metadados no SEI, deve ser analisada, pelo setor competente do Ibama, a pertinência das seguintes orientações, com vistas à padronização dos registros:

a. Esclarecer sobre a classificação dos "tipos de processo", inclusive exemplificando com casos concretos; 
b. Que no campo "especificação" seja identificado o documento que dá origem ao processo (ofício, auto de infração, etc.), copiando exatamente a identificação do documento original, bem como sua referência a assunto ou processo externo (número dos autos, inquérito, etc.);

c. Caso o documento externo recebido informe um número de processo do Ibama ou faça referência a documento anterior enviado (reiteração), deve-se evitar a abertura de novo processo, incluindo o documento no processo original;

d. Orientar sobre o correto preenchimento do campo "interessado", inclusive sobre a possibilidade de inclusão de mais de um para o mesmo processo, indicando a forma de padronização do registro e esclarecendo quem (pessoas físicas ou jurídicas) deve ser listado nesse campo;

e. Publicar a tabela de classificação de assuntos com as respectivas descrições, orientando a classificação dos processos mais frequentes, inclusive sobre a possibilidade de indicar mais de um assunto nessa classificação.

Enfatiza-se que as orientações para operação do SEI devem, preferencialmente, ser publicadas em manual de procedimentos do sistema e divulgadas amplamente entre todos os servidores efetivos e terceirizados, sobretudo aqueles que executam as atividades de protocolo. Da mesma forma, é importante que sejam disponibilizados permanentemente (na intranet, por exemplo) manuais atualizados de operação e de procedimentos, com linguagem objetiva e acessível, de todos os sistemas utilizados pelo Ibama.

Acerca da digitalização de documentos externos, sugere-se que sejam examinadas cuidadosamente as configurações para o escaneamento com OCR, inclusive realizando testes com documentos originais em diversos tipos de papel, com vistas a definir as especificações adequadas para padronização no Instituto.

Obviamente, diante do que foi relatado, é totalmente contraindicada a eliminação de qualquer processo com base na classificação por assuntos do SEI (como também dos processos físicos arquivados nas unidades do lbama). Ainda que seja aprovada a tabela de classificação utilizada atualmente, deve-se considerar que não há confiabilidade na classificação feita pelos usuários, sendo imprescindível a prévia verificação por profissional qualificado.

Outro ponto importante é que o lbama, por intermédio de sua assessoria jurídica, defina claramente os tipos de informação que podem ser disponibilizadas 
para acesso do público externo, distinguindo as que devem ser classificadas como reservadas ou sigilosas. Um bom exemplo a ser tratado são os processos das ações de fiscalização, que contém informações sobre infrações ambientais, mas também trazem dados pessoais dos autuados, o que gera conflito no acesso por terceiros.

Ademais, no tocante aos recursos humanos, é essencial que haja capacitação continuada não somente para operação dos sistemas informatizados, mas também nos temas relativos ao tratamento das informações registradas e sobre o acesso à informação pelo público externo. Diante do que foi observado, entende-se ser de grande importância que os servidores efetivos e terceirizados sejam adequadamente treinados não somente para operar mecanicamente, mas para compreender os sistemas como um todo, observando quais os dados que devem constar em cada campo e sua implicação para os usos posteriores.

De modo mais sistemático, as propostas descritas acima estão sintetizadas no Quadro 8:

Quadro 8 - Propostas para a gestão da informação no Ibama

\begin{tabular}{|c|c|}
\hline Ação & Detalhamento/Objetivo \\
\hline $\begin{array}{l}\text { Desenvolver/aprimorar os } \\
\text { sistemas informacionais }\end{array}$ & $\begin{array}{l}\text { - Possibilitar a geração de relatórios gerenciais } \\
\text { customizáveis; } \\
\text { - Aumentar a integração entre os sistemas; } \\
\text { - Melhorar as interfaces, com ênfase na usabilidade; } \\
\text { - Minimizar os erros na entrada de dados. }\end{array}$ \\
\hline $\begin{array}{l}\text { Rever as diretrizes para } \\
\text { digitalização de documentos }\end{array}$ & Melhorar a precisão do OCR \\
\hline $\begin{array}{l}\text { Padronizar o registro de } \\
\text { metadados }\end{array}$ & $\begin{array}{l}\text { Especificar que dados devem constar em cada campo } \\
\text { e o formato para o seu registro. }\end{array}$ \\
\hline $\begin{array}{l}\text { Publicar manuais de } \\
\text { procedimentos e operação dos } \\
\text { sistemas }\end{array}$ & $\begin{array}{l}\text { Disponibilizar permanentemente, na intranet, manuais } \\
\text { claros e detalhados para operação de todos os } \\
\text { sistemas. }\end{array}$ \\
\hline $\begin{array}{l}\text { Publicar tabela de classificação } \\
\text { de assuntos }\end{array}$ & $\begin{array}{l}\text { Possibilitar a correta classificação dos processos no } \\
\text { SEl, com vistas à melhoria da recuperação da } \\
\text { informação e aplicação da tabela de temporalidade. }\end{array}$ \\
\hline $\begin{array}{l}\text { Normatizar a classificação de } \\
\text { acesso }\end{array}$ & $\begin{array}{l}\text { Definir os tipos de informação passíveis de acesso do } \\
\text { público externo, distinguindo as informações que } \\
\text { devem ser classificadas como reservadas ou sigilosas. }\end{array}$ \\
\hline $\begin{array}{l}\text { Capacitação continuada dos } \\
\text { servidores }\end{array}$ & $\begin{array}{l}\text { Orientar sobre a operação dos sistemas, registro de } \\
\text { dados e técnicas de recuperação da informação, entre } \\
\text { outros. }\end{array}$ \\
\hline
\end{tabular}

Fonte: Elaboração própria, 2019. 


\section{CONSIDERAÇÕES FINAIS}

A teorização da pesquisa se concentrou no quadrante 2 da Figura 2 (p. 41), em parte porque é aí onde a luz da $\mathrm{Cl}$ está, especialmente em termos de tecnologia e seus pressupostos latentes de racionalidade, que muitas vezes as visões mais debatidas do comportamento em informação humana dominam.

Antes de tudo, analisar as informações dos processos de trabalho pressupõe refletir sobre o contexto social do lbama e examinar os fatores econômicos, políticos, ambientais que interferem e influenciam na gestão da organização. No cenário observado no estudo de caso, buscou-se identificar as maiores fragilidades e as possibilidades para o desenvolvimento da gestão da informação dentro do Instituto, de modo a melhor subsidiar as atividades finalísticas e a tomada de decisão.

Nesse sentido, foram apresentadas algumas possibilidades de tratamento e visualização dos dados coletados nos dois sistemas mais utilizados pelo Ibama, o Sicafi e o SEI, discorrendo-se acerca das limitações e lacunas observadas sobretudo na inserção de dados nesses sistemas, além das dificuldades na recuperação da informação. Infelizmente, a realidade observada é que os sistemas eletrônicos reproduzem as condições do arquivo físico quanto à recuperação da informação: têmse um grande volume de documentos acumulados, mas só se recupera aquilo que se sabe que lá está, ou seja, tendo os dados específicos mínimos para efetuar a buscas. Não há ferramentas ou lógica arquivística que possibilite a recuperação precisa por assunto, por exemplo, ou qualquer forma de cruzamento de dados.

A informatização dos processos públicos vem ocorrendo em razão da necessidade de modernização do trabalho, mas também como resposta à sociedade atual, que exige não só a disponibilidade dos documentos, como também maior agilidade nesse acesso. Essa também foi a motivação para a edição da Lei de Acesso à Informação (LAl), em 2011 (Lei o 12.527), que veio a regulamentar um direito já previsto na Constituição Federal, reduzindo as exigências e a burocracia tradicionalmente estabelecidas para o acesso e determinado a publicidade das informações como a regra, sendo o sigilo a exceção e necessariamente motivado, além da responsabilização do agente público que, sem justificativa explícita, negar o direito do acesso a qualquer cidadão que o requerer. 
Sem o risco do exagero, podemos afirmar que as mudanças apresentadas - a implantação do processo eletrônico e a Lei de Acesso à Informação - representam uma grande revolução nos modos de gerar e gerir as informações dentro das instituições públicas brasileiras. Infelizmente, ainda é válida a seguinte afirmação:

Os arquivos brasileiros ainda não estão inseridos nessa mudança de paradigma, pois estes são tão precários que muitas vezes ainda são denominados de "arquivo morto", todavia esta denominação pode até ter um fundo de veracidade, pois um arquivo ou depósitos que se encontra com esta denominação, não se valida de informação Arquivística. Essas condições são arrecadas aos arquivos, simplesmente pelo fato de que o seu gestor não ter o valor de socialização da informação ou tem o medo da transparência adquirida pela prática da gestão de documentos resultando assim na disseminação da informação. A falta de investimentos aos arquivos acarreta o caos documental e na falta do caráter social que cada informação registrada possui. (SILVA; SILVA, 2016, p. 111-112).

Nesse sentido, embora o arquivo, tal como conceituado pelos teóricos da Arquivologia, seja quase inexistente no contexto do serviço público, podemos fazer uma analogia entre os conceitos dos paradigmas custodial e pós-custodial, não em referência ao trabalho do arquivista, mas aqui referindo-nos à forma de pensar e agir dos servidores em relação à documentação produzida. Isso porque durante várias décadas a visão dos servidores públicos era (e ainda o é, em sua maioria) essencialmente custodial, patrimonialista, enxergando o documento como propriedade restrita e que deveria ser preservada longe dos olhos estranhos à instituição. De modo oposto, as novas diretrizes apontam para a necessidade de uma visão póscustodialista, exigindo dos agentes públicos uma visão da informação como direito da sociedade e, principalmente, como ferramenta para exercício da cidadania. Por outro lado, cabe destacar que as normas legais ainda apresentam lacunas, que trazem insegurança jurídica aos servidores. Ao mesmo tempo em que a LAl determina punição para o servidor que impedir o acesso à informação, também indica punição àquele que der o acesso indevido a informações restritas.

É necessário observar, ainda, o frequente despreparo dos profissionais encarregados de registrar as informações nos sistemas. Com pouca ou nenhuma noção de indexação, os documentos tendem a ser inseridos sem os metadados descritivos básicos ou mesmo com erros. Nas palavras de Sousa (1997, p. 7), "transfere-se para outros suportes a desorganização existente nos suportes originais" - o autor, nesse caso, referia-se às práticas de microfilmagem e digitalização de documentos, mas a afirmação continua verdadeira quando observadas as práticas 
atuais nos sistemas informatizados. Com a implantação do SEI, todos os servidores (efetivos ou terceirizados) estão habilitados a abrir processos e criar documentos, não havendo qualquer controle sobre os metadados que são inseridos no sistema. A falta de uma indexação eficiente prejudica em muito a recuperação da informação, obrigando quase sempre que o usuário do sistema tenha que acessar o conteúdo de vários documentos a fim de identificar aquele que de fato atende à sua necessidade.

Para suprir as deficiências na inserção dos metadados dos documentos e processos, é essencial que haja um treinamento de nivelamento mínimo para os servidores que operam o sistema, sobretudo aqueles que trabalham nas unidades de protocolo (COAD), que recepcionam e classificam os documentos externos. Da mesma forma, os trabalhos voltados para gestão da informação no ambiente do setor público não devem ficar dependentes da lotação acidental de um servidor com perfil adequado para tal atividade, e sim ser incluído no planejamento institucional, de modo que a competência informacional seja uma característica considerada e requerida em concursos para seleção de novos servidores, bem como incluídas capacitações sobre o tema para os servidores em atividade. Além disso, é imprescindível que os sistemas de informação sejam incrementados em termos de usabilidade, de modo a facilitar sua operação e minimizar os erros no preenchimento dos campos.

A partir da implantação do processo eletrônico, há, ao menos teoricamente, a suspensão no crescimento da massa documental acumulada nos órgãos públicos. Se bem administrado, ou seja, seguidas as boas práticas de preservação e segurança da informação armazenada em meio digital, o sistema eletrônico promete resolver os problemas de organização e recuperação das informações. No entanto, corre-se o risco de que todo o arquivo anteriormente armazenado - já em condições precárias caia totalmente no esquecimento. Isso significa a perda de décadas de informações, que não deveriam ser entendidas como memória estanque, mas sim como instrumentos da gestão institucional.

Assim, resta nítida a necessidade de capacitação dos agentes públicos, não somente para a utilização das novas ferramentas de informática, mas sobretudo na qualificação das atividades desenvolvidas, a fim de que haja de fato uma gestão da informação. Sobre o assunto, a Procuradora Federal Vânia Vieira discorre, em conferência sobre a então recém-publicada Lei de Acesso à Informação:

[...] Nós temos plena consciência de que talvez esse seja um dos principais e difíceis desafios que essa Lei de Acesso à Informação nos 
traz: garantir uma boa gestão da informação. Quando falo gestão, é desde o registro até o arquivamento dessa informação, porque se não tivermos um bom processo de gestão da informação, de gestão do conhecimento como um todo, por óbvio não seremos capazes de localizar, de levantar essa informação para entregá-la ao cidadão. (VIEIRA, 2012, p. 26).

Nesse contexto, observa-se que uma adequada gestão documental se mostra essencial para que seja possível o desenvolvimento da gestão da informação dentro das instituições. Embora se tenha a consciência das limitações orçamentárias para o investimento na organização dos acervos documentais e na melhoria dos sistemas informatizados e, principalmente, na contratação de novos servidores, deve-se considerar que há um custo não contabilizado do desperdício de tempo que é gasto frequentemente para se obter informações ou no retrabalho para produzir informações já registradas, pela dificuldade de encontrá-las.

Longe de abarcar todos os aspectos e questões relacionados à temática proposta, este trabalho apresentou um panorama do que foi observado no estudo de caso, apontando inúmeros caminhos para novas pesquisas relativas à gestão da informação no lbama, em particular, e na Administração Pública, de forma geral.

Empiricamente, observa-se no ambiente do serviço público a pertinência das teorias de Chatman (2001), Jonhson (2009) e Schwartz (2004) acerca da intencionalidade em evitar ou ignorar informações, de modo a esquivar-se de maiores responsabilidades ou comprometer-se com novas atividades. Destaca-se que o quadro cada vez mais reduzido de servidores implica em maior carga de trabalho para os que restam, e frequentemente aqueles que detêm mais conhecimento ou que se colocam dispostos a novas aquisições são mais solicitados a assumir outras obrigações. No entanto, tal constatação carece de suporte metodológico e observações sistemáticas, representando um campo fértil para novos estudos.

Em outra vertente, pesquisas aplicadas voltadas para a usabilidade e funcionalidade dos sistemas de informação utilizados pelos órgãos públicos se mostram necessárias e urgentes, compreendendo também a arquitetura da informação, acessibilidade e recuperação da informação.

Por ser um sistema adotado por diversos órgãos públicos, o SEI se apresenta como um campo bastante frutífero para novas investigações. Várias funcionalidades e aspectos do sistema não foram abordados aqui - por fugir ao propósito da pesquisa e pelo breve tempo disponível -, mas é possível apontar a necessidade de estudos 
com vistas a aprimorar a interface e usabilidade, além das questões específicas relacionadas aos problemas arquivísticos relatados.

Destaca-se, ainda, que os dados presentes no módulo do Cadastro Técnico Federal do Sicafi são extremamente ricos - referentes ao uso dos recursos naturais e emissão de poluentes pelas atividades econômicas desenvolvidas em todo o país -e servem de base para o Relatório de Qualidade do Meio Ambiente (RQMA) do Brasil. Assim, essa base de dados apresenta potencial para diversos estudos, tais como a qualificação dos dados e o estabelecimento de critérios de auditoria, visto que os dados são autodeclarados pelas empresas e deve-se buscar que sejam os mais fidedignos possível.

Por fim, destaca-se que o trabalho aqui apresentado reflete uma realidade compartilhada por praticamente todos os órgãos públicos brasileiros, carentes de estudos e ações de gestão da informação em vários aspectos, voltados para o aumento da eficiência e qualidade dos serviços prestados à população. 


\section{REFERÊNCIAS}

ABRÃO, Carlos Henrique. Processo eletrônico. Revista eletrônica [do] Tribunal Regional do Trabalho da 9 ${ }^{a}$ Região, Curitiba, PR, v. 2, n. 15, p. 53-62, jan./fev. 2013.

ALVES, Ítalo Henrique. O processo administrativo no âmbito do Programa de Gestão de Documentos. 2017. 259 f. Dissertação (Mestrado em Ciência da Informação) - Faculdade de Ciência da Informação, Universidade de Brasília, Brasília, 2017.

AMORIM, Ana Andrea Vieira Castro de. Arquivos e Informação: os caminhos da gestão de documentos na Universidade Federal da Paraíba. 2011. 115 f. Dissertação (Mestrado em Ciência da Informação). Universidade Federal da Paraíba, João Pessoa, 2011.

AMORIM, Fabiana Borelli; TOMAÉL, Maria Inês. O uso de sistemas de informação e seus reflexos na cultura organizacional e no compartilhamento de Informações.

Perspectivas em Gestão \& Conhecimento, João Pessoa, v. 1, n. 1, p. 74-91, jan./jun. 2011.

ARAÚJO, Carlos Alberto Ávila. Arquivologia, biblioteconomia, museologia e ciência da informação: o diálogo possível. Brasília, DF: Briquet de Lemos; São Paulo: Associação Brasileira de Profissionais da Informação, 2014.

ARQUIVO NACIONAL (Brasil). Considerações do Arquivo Nacional, órgão central do Sistema de Gestão de Documentos de Arquivo - SIGA, da administração pública federal acerca do Sistema Eletrônico de Informações SEI. Rio de Janeiro, 4 nov. 2015. Disponível em:

http://www.arquivonacional.gov.br/images/conteudo/artigos/SEl_analise_AN.pdf.

Acesso em: 27 set. 2018.

ASHFORD, Susan J.; BLATT, Ruth; VANDEWALLE, Don. Reflections on the Looking Glass: A Review of Research on Feedback-Seeking Behavior in Organizations. Journal of Management, [s. I.], v. 29, p. 773-799, 2003.

ASHFORD, Susan J.; CUMMINGS, L. L. Feedback as an individual resource: Personal strategies of creating information. Organizational Behavior and Human Performance, [s. I.], v. 32, p. 370-398, 1983.

AVELAR, Cátia Fabíola Parreira de; ROCHA, Thiago Augusto Hernandes; CRUZ, Flávia Juliesse Soares. Mineração de dados: uma revisão da literatura em Administração. Revista Vianna Sapiens, [s. I.], v. 8, n. 2, p. 25, dez. 2017.

BARBOSA, Ricardo Rodrigues. Gestão da informação e do conhecimento: origens, polêmicas e perspectivas. Inf. Inf., [Londrina], v. 13, n. esp p. 1-25, 2008. 
BATES, M. J. An introduction to metatheories, theories, and models. In: FISHER, K. E.; S. ERDELEZ, S.; MCKECHNIE, L. (ed.). Theories of Information Behavior. Medford, NJ: Information Today, 2005.

BAUMEISTER, Roy F. The self. In: GILBERT, Daniel T.; FISKE, Susan T.; LINDZEY, Gardner (org.). Handbook of social psychology. Boston: McGraw-Hill, 1998. vol. 1, cap. 15 , p. $680-740$.

BEAL, Adriana. Gestão estratégica da informação: como transformar a informação e a tecnologia da informação em fatores de crescimento e de alto desempenho nas organizações. São Paulo: Atlas, 2004.

BEM, Roberta Moraes; PRADO, Maria Lourde; DELFINO, Nelson. Desafios à implantação da gestão do conhecimento: a questão cultural nas organizações públicas federais brasileiras. Revista Digital de Biblioteconomia e Ciência da Informação, Campinas, SP, v. 11, n. 2, p. 125-135, maio/ago. 2013.

BRASIL. Lei no 6.938, de 31 de agosto de 1981. Dispõe sobre a Política Nacional do Meio Ambiente, seus fins e mecanismos de formulação e aplicação, e dá outras providências. Diário Oficial da União, Brasília, DF, 2 set. 1981. Disponível em: http://www.planalto.gov.br/ccivil_03/Leis/L6938.htm. Acesso em 19 jan. 2019.

BRASIL. [Constituição (1988)]. Constituição da República Federativa do Brasil. Brasília, DF: Presidência da República, [2016]. 1988. Disponível em: http://www.planalto.gov.br/ccivil_03/Constituicao/Constituicao.htm. Acesso em: 19 jan. 2019.

BRASIL. Lei ํㅜ 7.735, de 22 de fevereiro de 1989. Dispõe sobre a extinção de órgão e de entidade autárquica, cria o Instituto Brasileiro do Meio Ambiente e dos Recursos Naturais Renováveis e dá outras providências. Diário Oficial da União, Brasília, DF, 23 fev. 1989. Disponível em: http://www.planalto.gov.br/ccivil_03/LEIS/L7735.htm. Acesso em: 19 jan. 2019.

BRASIL. Lei no 8.159, de 8 de janeiro de 1991. Dispõe sobre a política nacional de arquivos públicos e privados e dá outras providências. Diário Oficial da União, Brasília, DF, 9 jan. 1991. Disponível em:

http://www.planalto.gov.br/ccivil_03/LEIS/L8159.htm. Acesso em: 19 jan. 2019.

BRASIL. Lei 9.605, de 12 de fevereiro de 1998. Dispõe sobre as sanções penais e administrativas derivadas de condutas e atividades lesivas ao meio ambiente, e dá outras providências. Diário Oficial da União, Brasília, DF, 13 fev.1998. Retificado em 17 fev. 1998. Disponível em:

http://www.planalto.gov.br/ccivil_03/LEIS/L9605.htm. Acesso em: 19 jan. 2019.

BRASIL. Lei no 9.784, de 29 de janeiro de 1999. Regula o processo administrativo no âmbito da Administração Pública Federal. Diário Oficial da União, Brasília, DF, 1 fev. 1999. Retificado em 11 mar. 1999. Disponível em:

http://www.planalto.gov.br/ccivil_03/LEIS/L9784.htm. Acesso em: 19 jan. 2019. 
BRASIL. Lei no 10.650, de 16 de abril de 2003. Dispõe sobre o acesso público aos dados e informações existentes nos órgãos e entidades integrantes do Sisnama. Diário Oficial da União, Brasília, DF, 17 abr. 2003. Disponível em: http://www.planalto.gov.br/ccivil_03/leis/2003/L10.650.htm. Acesso em: 19 jan. 2019.

BRASIL. Lei n 11.284, de 2 de março de 2006. Dispõe sobre a gestão de florestas públicas para a produção sustentável; institui, na estrutura do Ministério do Meio Ambiente, o Serviço Florestal Brasileiro - SFB; cria o Fundo Nacional de Desenvolvimento Florestal - FNDF; altera as Leis $\mathrm{n}^{\circ} \mathrm{s} 10.683$, de 28 de maio de 2003, 5.868, de 12 de dezembro de 1972, 9.605, de 12 de fevereiro de 1998, 4.771, de 15 de setembro de 1965, 6.938, de 31 de agosto de 1981, e 6.015, de 31 de dezembro de 1973; e dá outras providências. Diário Oficial da União, Brasília, DF, 3 mar. 2006. Disponível em: http://www.planalto.gov.br/ccivil_03/_Ato20042006/2006/Lei/L11284.htm. Acesso em: 19 jan. 2019.

BRASIL. Lei nำ 11.419, de 19 de dezembro de 2006. Dispõe sobre a informatização do processo judicial; altera a Lei no 5.869, de 11 de janeiro de 1973 - Código de Processo Civil; e dá outras providências. Diário Oficial da União, Brasília, DF, 20 dez. 2006. Disponível em: http://www.planalto.gov.br/ccivil_03/_Ato20042006/2006/Lei/L11419.htm. Acesso em: 19 jan. 2019.

BRASIL. Lei no 11.516, de 28 de agosto de 2007. Dispõe sobre a criação do Instituto Chico Mendes de Conservação da Biodiversidade - Instituto Chico Mendes; altera as Leis nํs 7.735, de 22 de fevereiro de 1989, 11.284, de 2 de março de 2006, 9.985, de 18 de julho de 2000, 10.410, de 11 de janeiro de 2002, 11.156, de 29 de julho de 2005, 11.357, de 19 de outubro de 2006, e 7.957, de 20 de dezembro de 1989; revoga dispositivos da Lei no 8.028, de 12 de abril de 1990, e da Medida Provisória no 2.216-37, de 31 de agosto de 2001; e dá outras providências. Diário Oficial da União, Brasília, DF, 28 ago. 2007, Edição extra. Disponível em: http://www.planalto.gov.br/ccivil_03/_Ato2007-2010/2007/Lei/L11516.htm. Acesso em: 19 jan. 2019.

BRASIL. Lei no 12.527, de 18 de novembro de 2011. Regula o acesso a informações previsto no inciso XXXIII do art. 5ำ, no inciso II do $\S 3^{\circ}$ do art. 37 e no $\S 2^{\circ}$ do art. 216 da Constituição Federal; altera a Lei no 8.112, de 11 de dezembro de 1990; revoga a Lei no 11.111, de 5 de maio de 2005, e dispositivos da Lei no 8.159, de 8 de janeiro de 1991; e dá outras providências. Diário Oficial da União, Brasília, DF, 18 nov. 2011, Edição extra. Disponível em: http://www.planalto.gov.br/ccivil_03/_ato20112014/2011/lei/l12527.htm. Acesso em: 19 jan. 2019.

BRASIL. Lei Complementar no 140, de 8 de dezembro de 2011. Fixa normas, nos termos dos incisos III, VI e VII do caput e do parágrafo único do art. 23 da Constituição Federal, para a cooperação entre a União, os Estados, o Distrito Federal e os Municípios nas ações administrativas decorrentes do exercício da competência comum relativas à proteção das paisagens naturais notáveis, à proteção do meio ambiente, ao combate à poluição em qualquer de suas formas e à preservação das florestas, da fauna e da flora; e altera a Lei no 6.938, de 31 de agosto de 1981. Diário Oficial da União, Brasília, DF, 9 dez. 2011. Retificado em 12 dez. 2011. Disponível em:

http://www.planalto.gov.br/ccivil_03/LEIS/LCP/Lcp140.htm. Acesso em: 19 jan. 2019. 
BRASIL. Lei nำ12.651, de 25 de maio de 2012. Dispõe sobre a proteção da vegetação nativa; altera as Leis nำ 6.938, de 31 de agosto de 1981, 9.393, de 19 de dezembro de 1996, e 11.428, de 22 de dezembro de 2006; revoga as Leis nos 4.771, de 15 de setembro de 1965, e 7.754, de 14 de abril de 1989, e a Medida Provisória no 2.166-67, de 24 de agosto de 2001; e dá outras providências. Diário Oficial da União, Brasília, DF, 28 maio 2012. Disponível em:

http://www.planalto.gov.br/ccivil_03/_Ato2011-2014/2012/Lei/L12651.htm. Acesso em: 19 jan. 2019.

BRASIL. Lei no 12.682, de 9 de julho de 2012. Dispõe sobre a elaboração e o arquivamento de documentos em meios eletromagnéticos. Diário Oficial da União, Brasília, DF, 10 jul. 2012. Disponível em:

http://www.planalto.gov.br/ccivil_03/_ato2011-2014/2012/Lei/L12682.htm. Acesso em: 19 jan. 2019.

BRASIL. Decreto ํㅜ 8.539, de 8 de outubro de 2015. Dispõe sobre o uso do meio eletrônico para a realização do processo administrativo no âmbito dos órgãos e das entidades da administração pública federal direta, autárquica e fundacional. Diário Oficial da União, Brasília, DF, 9 out. 2015. Disponível em: http://www.planalto.gov.br/ccivil_03/_Ato2015-2018/2015/Decreto/D8539.htm. Acesso em: 19 jan. 2019.

BRASIL. Decreto no 8.638, de 15 de janeiro de 2016. Institui a Política de Governança Digital no âmbito dos órgãos e das entidades da administração pública federal direta, autárquica e fundacional. Diário Oficial da União, Brasília, DF, 18 jan. 2016. Disponível em: http://www.planalto.gov.br/ccivil_03/_Ato20152018/2016/Decreto/D8638.htm. Acesso em: 19 jan. 2019.

BRASIL. Decreto no 8.777, de 11 de maio de 2016. Institui a Política de Dados Abertos do Poder Executivo federal. Diário Oficial da União, Brasília, DF, 12 maio 2016. Disponível em: http://www.planalto.gov.br/CCIVIL_03/_Ato20152018/2016/Decreto/D8777.htm. Acesso em: 19 jan. $201 \overline{9}$.

BRASIL. Decreto nํ 8.973, de 24 de janeiro de 2017. Aprova a Estrutura Regimental e o Quadro Demonstrativo dos Cargos em Comissão e das Funções de Confiança do Instituto Brasileiro do Meio Ambiente e dos Recursos Naturais Renováveis IBAMA, remaneja cargos em comissão e substitui cargos em comissão do GrupoDireção e Assessoramento Superiores - DAS por Funções Comissionadas do Poder Executivo - FCPE. Diário Oficial da União, Brasília, DF, 25 jan. 2017. Disponível em: http://www.planalto.gov.br/ccivil_03/_ato2015-2018/2017/decreto/D8973.htm. Acesso em: 19 jan. 2019.

BRASIL. Ministério do Planejamento, Desenvolvimento e Gestão. Portal do Software Público Brasileiro. Manual do usuário SEI: versão 3.0. Brasília, DF: Ministério do Planejamento, Desenvolvimento e Gestão, [201-?] Disponível em: https://softwarepublico.gov.br/social/articles/0004/9746/sei-doc-usuario.pdf. Acesso em 14. dez. 2018. 
BROOKES, Bertram C. The foundation of Information Science. Journal of Information Science, [s. I.], v. 2, part. I, p. 125-133, 1980.

CASE, Donald O.; ANDREWS, James E.; JOHNSON, J. David; ALLARD, Suzanne L. Avoiding versus seeking: The relationship of information seeking to avoidance, blunting, coping, dissonance and related concepts. Journal of Medical Libraries Association, [s. I.], v. 93, p. 48-57, jul. 2005.

CASE, Donald O. Information behaviour. Annual Review of Information Science and Technology, [s. I.], v. 40, cap. 7, p. 293-328, 2006.

CASE, Donald O. Looking for information. 2. ed. New York: Academic Press, 2007.

CASE, Donald O. Looking for information: a survey of research on information seeking, needs and behaviour. 3. ed. Bingley: Emerald Group Publishing, 2012.

CHATMAN, Elfreda A. Framing social life in theory and research. In: Höglund, L. (org.). Information seeking in context: Proceedings of the 3rd International Conference on Research in Information Needs, Seeking and Use in Different Contexts. London, UK: Taylor Graham, 2001.

$\mathrm{CHOO}$, Chun Wei. Information management for the intelligent organization: the art of scanning the environment. 2. ed. [S. I.: s. n.], 1998. (ASIS Monograph Series).

$\mathrm{CHOO}$, Chun Wei. A organização do conhecimento: como as organizações usam a informação para criar significado, construir conhecimento e tomar decisões.

Tradução de: Eliana Rocha. São Paulo: Senac, 2003.

COOL, Colleen. The concept of situation in information science. Annual Review of Information Science and Technology, [s. I.], v. 35, p. 5-42, 2001.

DAVENPORT, Thomas H. Ecologia da Informação: por que só a tecnologia não basta para o sucesso na era da informação. São Paulo: Futura, 1998. Tradução de: Bernadette Siqueira Abrão.

DERVIN, Brenda. Strategies for dealing with human information needs: Information or communication? Journal of Broadcasting, [s. I.], v. 20, p. 324-351, 1976.

DERVIN, Brenda. Given a context by any other name: Methodological tools for taming the unruly beast. In: VAKKARI, P.; SAVOLAINEN, R.; DERVIN, B. (ed.). Information seeking in context. London: Taylor Graham, 1997. p. 13-38.

DIAS, Mateus Pereira; CARVALHO, José Oscar Fontanini de. A visualização da informação e a sua contribuição para a Ciência da Informação. DataGramaZero, [s. I.] v. 8, n. 5, out. 2007.

ERDELEZ, Sanda. Information encountering: a conceptual framework for accidental information discovery. In: VAKKARI, P.; SAVOLAINEN, R.; DERVIN, B. (org.). Information seeking in context: Proceedings of an International Conference on 
Research in Information Needs, Seeking and Use in Different Contexts. London, UK: Taylor Graham; 1997.

FADEL, Bárbara; ALMEIDA, Carlos Cândido de; CASARIN, Helen de Castro Silva; VALENTIM, Marta Lígia Pomim; ALMEIDA JÚNIOR, Oswaldo Francisco de; BELLUZZO, Regina Célia Baptista. Gestão, mediação e uso da informação. In: VALENTIM, Marta (org.). Gestão, mediação e uso da informação. São Paulo: Editora Unesp; Cultura Acadêmica, 2010. cap. 1.

FISHER, Karen E.; JULIEN, Heidi. Information behaviour. Annual Review of Information Science and Technology, [s. I.], v. 43, cap. 7, p. 317-358, 2009.

FONDAS, Nanette. Feminization unveiled: Management qualities in contemporary writings. The Academy of Management Review, [s. I.], v. 22, p. 223-257, 1997.

FONSECA, Maria Odila Kahl. Arquivologia e ciência da informação. [Edição do Kindle]. Rio de Janeiro: FGV, 2005. E-book.

FOURIE, Ina. Review of research on information behaviour in contexts of palliative care with an indication of some research gaps. Afr. J. Lib. Arch. \& Inf. Sc., [s. I.], v. 23, n. 1, p. 23-32, apr. 2013.

FREITAS, Carla Maria Dal Sasso; CHUBACHI, Olinda Mioka; LUZZARDI, Paulo Roberto Gomes; CAVA, Ricardo Andrade. Introdução à visualização de informações. Revista de Informática Teórica e Aplicada, Porto Alegre, RS, v. 8, n. 2, p. 143158, out. 2001.

FREITAS, Henrique; JANISSEK-MUNIZ, Raquel. Uma proposta de plataforma para Inteligência Estratégica. In: CONGRESSO IBERO-AMERICANO DE GESTÃO DO CONHECIMENTO E INTELIGÊNCIA COMPETITIVA, 1., 2006, Curitiba, PR. Anais [...] Curitiba, PR: [CIETEP], 2006.

FROHMANN, Bernd. The power of images: a discourse analysis of the cognitive viewpoint. Journal of Documentation, London, v. 48, n. 4, p. 365-386, 1992.

GOLEMAN, Daniel; BOYATZIS, Richard E.; MCKEE, Annie. Primal leadership: Realizing the power of emotional intelligence. Boston: Harvard Business School, 2002.

HERSBERGER, Julie. Chatman's information poverty. In: FISHER, K. E.; ERDELEZ, S.; MCKECHNIE, L. (org.). Theories of information behavior. Medford, NJ: Information Today, 2005, p. 75-78.

HJØRLAND, Birger. Information seeking and subject representation. London: Grenwood Press, 1996.

IBAMA. Portaria no 9, de 5 de junho de 2012. Institui a Política de Segurança da Informação, Informática e Comunicações (Posic) do Instituto Brasileiro do Meio Ambiente e dos Recursos Naturais Renováveis (Ibama). Diário Oficial da União: seção 1, Brasília, DF, p. 151-154, 6 jun. 2012. 
IBAMA. Instrução Normativa Ibama oㅜ 10, de 7 de dezembro de 2012. Regula os procedimentos para apuração de infrações administrativas por condutas e atividades lesivas ao meio ambiente, a imposição das sanções, a defesa, o sistema recursal e a cobrança de multas no âmbito do IBAMA. Diário Oficial da União: seção 1, Brasília, DF, p. 233-239, 13 dez. 2012.

IBAMA. Carta de serviços ao cidadão. Brasília, DF, 2014. Disponível em: http://www.ibama.gov.br/phocadownload/institucional/carta-de-servicos-aocidadao.pdf. Acesso em 07.nov.2017.

IBAMA. Plano Estratégico do Ibama para o ciclo 2016-2019. Portaria ํㅡ 20, de 08/08/2016. Boletim de Serviço Especial no 08. Brasília, DF, 2016.

IBAMA. Portaria $n^{\circ}$ 24, de 16 de agosto de 2016. Aprova o Regulamento Interno de Fiscalização Ambiental (RIF) do Ibama. Diário Oficial da União: seção 1, Brasília, DF, 22 p. 78-84, ago. 2016.

IBAMA. Plano de dados abertos: vigência - 2018 a 2019. Brasília, DF, 2017.

IBAMA. Portaria ํo 09, de 24.04.2017. Estabelece e padroniza os procedimentos do processo eletrônico e gestão de documentos, processos e arquivo pelo Sistema Eletrônico de Informações - SEI no âmbito do Instituto Brasileiro do Meio Ambiente e dos Recursos Naturais Renováveis - IBAMA. Boletim de Serviço Especial no 04-C. Brasília, DF, 26 abr. 2017.

IBAMA. Portaria no 14, de 29 de junho de 2017. Aprovar o Regimento Interno do Instituto Brasileiro do Meio Ambiente e dos Recursos Naturais Renováveis - IBAMA. Diário Oficial da União: seção 1, Brasília, DF, p. 84-95, 30 jun. 2017.

IBAMA. Plano Diretor de Tecnologia da Informação e Comunicações (PDTIC) do Ibama: 2017 - 2019. 2. ed. Brasília, DF: Ministério do Meio Ambiente, 2018.

IBAMA. Relatório anual de atividades da Auditoria Interna: exercício de 2017. Portaria no 885, de 02/04/2018. Boletim de Serviço 04. Brasília, DF, p. 2-17, 6 abr. 2018.

JOHNSON, J. David. Information seeking: An organizational dilemma. Quorum Books, 1996.

JOHNSON, J. David. An impressionistic mapping of information behavior with special attention to contexts, rationality, and ignorance. Information Processing and Management, [s. I.], v. 45, p. 593-604, 2009.

KERWIN, Ann. None too solid: Medical ignorance. Knowledge: Creation, Diffusion, Utilization, v. 15, p. 166-185, 1993.

KUHLTHAU, Carol C. Inside the search process: information seeking from the user's perspective. Journal of the American Society for Information Science, New Jersey, v. 42, n. 5, p. 361-371, june, 1991. 
KUHLTHAU, Carol C. Seeking meaning: A process approach to library and information services. 2. ed. Westport, CT: Libraries Unlimited, 2004.

LAVILLE, Christian; DIONNE, Jean. A construção do saber: manual de metodologia de pesquisa em Ciências Humanas. Porto Alegre: Artmed; Belo Horizonte: Ed. UFMG, 1999.

LE COADIC, Yves-François. A ciência da informação. Tradução Maria Yêda F. S. de Filgueiras Gomes. 2. ed. rev. e atual. Brasília: Briquet de Lemos, 2004.

MCGEE, James; PRUSAK, Laurence. Gerenciamento estratégico da informação: aumente a competitividade e a eficiência da sua empresa utilizando a informação como uma ferramenta estratégica. Rio de Janeiro: Campus, 1994.

MORRISON, Elizabeth Wolfe; MILLIKEN, Frances J. Organizational silence: A barrier to change and development in a pluralistic world. The Academy of Management Review, [s. I.], v. 25, p. 706-725, 2000.

NAHL, D.; BILAL, D. Information and emotion. The emergent affective paradigm in information behavior research and theory. Medford, NJ: Information Today, 2007.

NASCIMENTO, Hugo A. D. do; FERREIRA, Cristiane B. R. Uma introdução à visualização de informações. Visualidades, Goiânia, v. 9, n. 2, p. 13-43, jul./dez. 2011.

NORTHCRAFT, Gregory B.; ASHFORD, Susan J. The preservation of self in everyday life: The effects of performance expectations and feedback context on feedback inquiry. Organizational Behavior and Human Decision Processes, [s. I.], v. 47 , p. $42-64,1990$.

OLIVEIRA, Cacilene Toscano. O gerenciamento eletrônico de documentos sob a ótica da representação da informação arquivística. Archeion Online, João Pessoa, v. 2, n. 1, p. 23-26, jan./jun. 2014.

PAVÃO, Caterina Groposo; COSTA, Janise Borges da; FERREIRA, Manuela Klanovicz; HOROWITZ, Zaida. Metadados e repositórios institucionais: uma relação indissociável para a qualidade da recuperação e visibilidade da informação.

PontodeAcesso, Salvador, v. 9, n. 2, p.103-116, dez. 2015.

PETTIGREW, Karen E. Waiting for Chiropody: Contextual results from an ethnographic study of the information behavior among attendees at community clinics. Information Processing \& Management, [s. I.], v. 35, n. 6, p. 801-817, 1999.

PETTIGREW, Karen E.; FIDEL, Raya; BRUCE, Harry. Conceptual frameworks in information behavior. Annual Review of Information Science and Technology, [s. I.], v. 35, p. 43-78, 2000. 
PONJUÁN DANTE, Gloria. La gestión de información y sus modelos representativos. Valoraciones. Ciencias de la Información, La Habana, v. 42, n. 2, p. 11-17, mayo/ago. 2011.

PRESSER, Nadi Helena; GONZÁLEZ, José Antonio Moreiro. Práticas culturais e comportamento social em informação. Em Questão, Porto Alegre, v. 23, n. 3, p. 11 31, set./dez. 2017.

RODRIGUES, Ana Célia. Identificação como requisito metodológico para a gestão de documentos e acesso à informações na administração pública brasileira. Ciência da Informação, Brasília, DF, v. 42, n. 1, p. 64-80, jan./abr. 2013.

RONDINELLI, Rosely Curi. Gerenciamento arquivístico de documentos eletrônicos: uma abordagem teórica da diplomática arquivística contemporânea. 4. ed. [Edição do Kindle] Rio de Janeiro: FGV, 2005. E-book.

ROZADOS, Helen B. F. Indicadores como ferramenta para gestão de serviços de informação tecnológica. 2004. 239 f. Tese (Doutorado em Ciência da Informação) - Faculdade de Biblioteconomia e Comunicação, Universidade Federal do Rio Grande do Sul, Porto Alegre, 2004.

SAGAN, Carl. O mundo assombrado pelos demônios: A ciência vista como uma vela no escuro. [Edição do Kindle] São Paulo: Companhia das Letras, 2009. E-book.

SANTOS, Milton. Técnica, espaço, tempo: globalização e meio técnico-científicoinformacional. São Paulo: Hucitec, 1994.

SAVOLAINEN, Reijo. Everyday life information seeking: Approaching information seeking in the context of "way of life". Library and Information Science Research, [s. I.], v. 17, p. 259-294, 1995.

SAVOLAINEN, Reijo. Everyday life information seeking. In: FISHER, K. E., ERDELEZ, S.; MCKECHNIE, L. (ed.). Theories of information behavior. Medford, NJ: Information Today, 2005. p. 143-148.

SCHELLENBERG, Theodore R. Arquivos modernos: princípios e técnicas. Tradução Nilza Teixeira Soares. 6. ed. [Edição do Kindle]. Rio de Janeiro: Editora FGV, 2006. E-book.

SCHWARTZ, B. Paradox of choice: Why more is less. New York: Harper Collins, 2004.

SERRES, Michel. O contrato natural. Lisboa: Instituto Piaget, 1991.

SILVA, Fábio Mascarenhas; SMIT, Johanna Wilhelmina. Organização da informação em sistemas eletrônicos abertos de Informação Científica \& Tecnológica: análise da Plataforma Lattes. Perspectivas em Ciência da Informação, [s. I.], v. 14, n. 1, p. 77-98, jan./abr. 2009. 
SILVA, Irisneide de Oliveira Souza; FUJITA, Mariângela Spotti Lopes; DAL' EVEDOVE, Paula Regina. A relação entre Arquivística e Ciência da Informação na sociedade pós-moderna. Ibersid: Revista de Sistemas de Información y Documentación, [s. I.], v. 3, p. 281-289, 2009.

SONNENWALD, Diane H. Evolving Perspectives of Human Information Behavior: Contexts, Situations, Social Networks and Information Horizons. In:

INTERNATIONAL CONFERENCE IN INFORMATION NEEDS, 2., 1999, [s. I.]. Proceedings [...]. [s. I.]:Taylor Graham, 1999. p. 176-190. Disponível em: http://eprints.rclis.org/7971/1/isic98\%2Bpaper.pdf. Acesso em 11 mar. 2018.

SONNENWALD, Diane H.; WILDEMUTH, Barbara M.; HARMON, Gary L. A research method to investigate information seeking using the concept of information horizons: an example from a study of lower socioeconomic students' information seeking behavior. The New Review of Information Behavior Research, [s. I.], v. 2, p. 6585, 2001.

SOUSA, Renato Tarciso Barbosa de. Os arquivos montados nos setores de trabalho e as massas documentais acumuladas na administração pública brasileira: uma tentativa de explicação. Revista de Biblioteconomia de Brasília, [Brasília], v. 21, n. 1, p. 31-50, 1997. Disponível em:

https://arquivoememoria.files.wordpress.com/2009/04/arquivosmontadossetorestraba Iho.pdf. Acesso em: 3 jun. 2017.

SPINK, Amanda; COLE, Charles. Human information behavior: Integrating diverse approaches and information use. Journal of the American Society for Information Science and Technology, [s. I.], v. 57, p. 25-35, 2006.

TALJA, Sanna; KESO, Heidi; PIETILAINEN, Targa. The production of context in information seeking research: A metatheoretical view. Information Processing Management, [s. I.], v. 35, n. 6, p. 751-763, 1999.

TARAPANOFF, Kira. Inteligência social e inteligência competitiva. Organizações em Contexto, [s. I.], ano 3, n. 5, p. 207-222, jun. 2007.

TUOMINEN, Kimmo; SAVOLAINEN, Reijo. A social constructionist approach to the study of information use as discursive action. In: VAKKARI, P.; SAVOLAINEN, R.; DERVIN, B. (org.). Information seeking in context: Proceedings of an International Conference on Research in Information Needs, Seeking and Use in Different Contexts. London, UK: Taylor Graham, 1997. p. 81-96.

UCHÔA, Carlos Eduardo. O processo de implantação do SEI - Sistema Eletrônico de Informações no Ministério do Planejamento, Orçamento e Gestão. In: CONGRESSO CONSAD DE GESTÃO PÚBLICA, 7., 2014, Brasília. Anais eletrônicos [...]. Brasília: [s. n.], 2014. Disponível em: http://banco.consad.org.br/handle/123456789/1131. Acesso em 3 jul. 2017.

VENANCIO, Renato Pinto; FEITLER, Bruno. Arquivos sob ameaça: os perigos de uma política antiarquivística. Revista Brasileira de História, São Paulo, v. 38, n. 78, p. 7-14, ago. 2018. 
VETRIVEL, R. S.; NIYOPERPASILINE, J.; JEYANTHIRANI, P. Investigation Study on Vantage Point Indexing Search in Multiple Data Pattern Mining. International Journal of Advanced Research in Computer Science \& Technology, [IJARCST], v. 5, n. 1, jan./mar. 2017.

VITORIANO, Marcia Cristina de Carvalho Pazin. Uma aproximação entre Arquivologia e Ciência da Informação: o uso dos conceitos de informação orgânica e informação arquivística. Brazilian Journal of Information Science, [Marília], v. 11, n. 4, p. 57-66, 2017.

WILLIAMSON, Kirsty. Discovered by chance: The role of incidental information acquisition in an ecological model of information use. Library and Information Science Research, [s. I.], v. 20, p. 23-40, 1998.

WILSON, T. D. Models in information behaviour research. Journal of Documentation, [s. I.], v. 55, n. 3, p. 249-270, 1999.

WILSON, T. D. Human information behavior. Informing science, Sheffield, v. 3, n. 2, p. 49-53, 2000. Disponível em: http://inform.nu/Articles/Vol3/v3n2p49-56.pdf. Acesso em: 6 nov. 2017.

ZIPF, George Kingsley. Human behavior and the principle of least effort: An introduction to human ecology. Cambridge, MA: Addison-Wesley, 1949. 
APÊNDICE A - TRAMITAÇÃO DOS PROCESSOS DE AUTO DE INFRAÇÃO

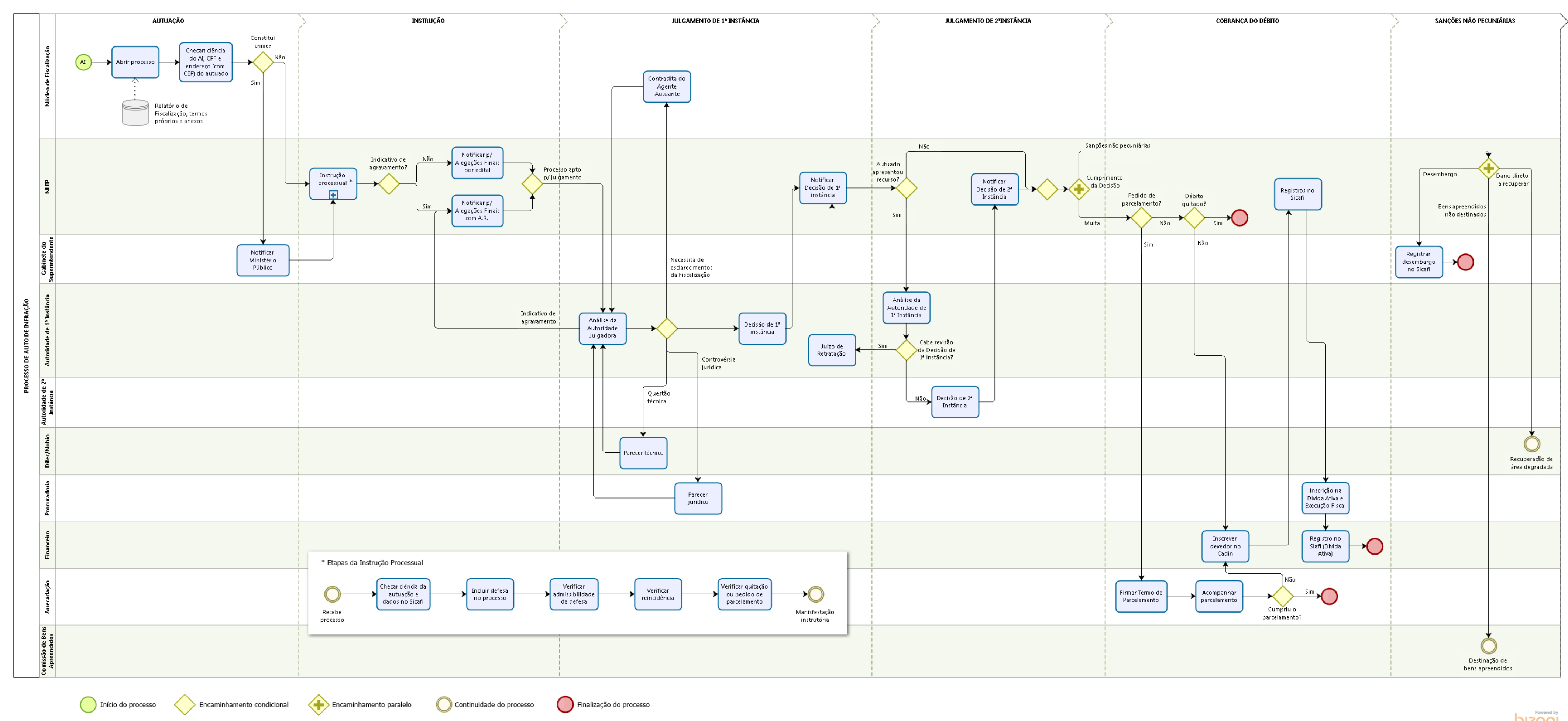

Fluxo de tramitação dos processos de Autos de Infração do Ibama, no qual cada linha corresponde ao setor responsável pela ação e as colunas identificam as etapas dos processos. Fonte: Elaboração própria. 


\section{APÊNDICE B - PLANILHA DE DADOS COLETADOS DO SICAFI}

Autos de Infração lavrados em Pernambuco de 2013 a 2017

\begin{tabular}{|c|c|c|c|c|c|c|c|}
\hline № Processo & № Auto & Série & Tipo de Infração & Data Auto & Valor & Município & Ano \\
\hline 02019.000284/2013-93 & 743401 & D & Fauna & $18 / 01 / 2013$ & $\mathrm{R} \$ 13.000,00$ & PARNAMIRIM & 2013 \\
\hline 02006.000242/2013-00 & 96779 & D & Pesca & 22/01/2013 & $\mathrm{R} \$ 1.000,00$ & PETROLINA & 2013 \\
\hline 02019.000055/2013-79 & 743522 & D & $\begin{array}{l}\text { Cadastro Técnico } \\
\text { Federal }\end{array}$ & $24 / 01 / 2013$ & $\mathrm{R} \$ 500.000,00$ & PALMARES & 2013 \\
\hline 02019.000125/2013-99 & 743322 & D & Controle ambiental & $24 / 01 / 2013$ & $\mathrm{R} \$ 500.000,00$ & AGUA PRETA & 2013 \\
\hline 02019.000081/2013-05 & 696134 & D & Pesca & $30 / 01 / 2013$ & $\mathrm{R} \$ 1.780,00$ & TAMANDARE & 2013 \\
\hline 02019.000193/2013-58 & 695671 & D & Pesca & $30 / 01 / 2013$ & $\mathrm{R} \$ 1.060,00$ & PAULISTA & 2013 \\
\hline 02019.000176/2013-11 & 695861 & D & Pesca & $02 / 02 / 2013$ & $\mathrm{R} \$ 8.400,00$ & $\begin{array}{l}\text { CABO DE SANTO } \\
\text { AGOSTINHO }\end{array}$ & 2013 \\
\hline 02019.000329/2013-20 & 695862 & D & Pesca & $02 / 02 / 2013$ & $\mathrm{R} \$ 2.100,00$ & ESCADA & 2013 \\
\hline 02019.000108/2013-51 & 743523 & D & Pesca & $02 / 02 / 2013$ & $\mathrm{R} \$ 1.300,00$ & $\begin{array}{l}\text { CABO DE SANTO } \\
\text { AGOSTINHO }\end{array}$ & 2013 \\
\hline 02019.000195/2013-47 & 695673 & D & Pesca & $02 / 02 / 2013$ & $\mathrm{R} \$ 1.140,00$ & $\begin{array}{l}\text { CABO DE SANTO } \\
\text { AGOSTINHO }\end{array}$ & 2013 \\
\hline 02019.000194/2013-01 & 695672 & D & Pesca & $02 / 02 / 2013$ & $\mathrm{R} \$ 1.108,00$ & $\begin{array}{l}\text { CABO DE SANTO } \\
\text { AGOSTINHO }\end{array}$ & 2013 \\
\hline 02019.000140/2013-37 & 695908 & $\mathrm{D}$ & Pesca & $02 / 02 / 2013$ & $\mathrm{R} \$ 1.040,00$ & SIRINHAEM & 2013 \\
\hline 02019.000141/2013-81 & 695909 & $\mathrm{D}$ & Pesca & $02 / 02 / 2013$ & $\mathrm{R} \$ 1.040,00$ & IPOJUCA & 2013 \\
\hline 02019.000144/2013-15 & 743443 & $\mathrm{D}$ & Pesca & 02/02/2013 & $\mathrm{R} \$ 1.020,00$ & IPOJUCA & 2013 \\
\hline 02019.000196/2013-91 & 743524 & D & $\begin{array}{l}\text { Unidades de } \\
\text { conservação }\end{array}$ & $02 / 02 / 2013$ & $\mathrm{R} \$ 1.040,00$ & SIRINHAEM & 2013 \\
\hline 02019.000139/2013-11 & 696096 & D & Fauna & $04 / C$ & $\mathrm{R} \$ 46.000,00$ & IATI & 2013 \\
\hline 02019.000109/2013-04 & 695381 & D & $\begin{array}{l}\text { Cadastro Técnico } \\
\text { Federal }\end{array}$ & $14 / 02 / 2013$ & $\mathrm{R} \$ 20.000,00$ & TIMBAUBA & 2013 \\
\hline 02001.000477/2013-33 & 723706 & D & $\begin{array}{l}\text { Org. Gen. Modific. e } \\
\text { Biopirataria }\end{array}$ & $14 / 02 / 2013$ & $R \$ 50.000,00$ & RECIFE & 2013 \\
\hline 02019.000191/2013-69 & 695383 & D & Controle ambiental & $19 / 02 / 2013$ & $\mathrm{R} \$ 10.000,00$ & SIRINHAEM & 2013 \\
\hline 02019.000124/2013-44 & 743287 & D & Fauna & 20/02/2013 & $\mathrm{R} \$ 1.000,00$ & IGARASSU & 2013 \\
\hline 02019.000143/2013-71 & 695609 & D & Flora & $22 / 02 / 2013$ & $\mathrm{R} \$ 6.259,50$ & GRAVATA & 2013 \\
\hline 02019.000306/2013-15 & 743403 & D & Fauna & $25 / 02 / 2013$ & $\mathrm{R} \$ 8.000,00$ & SERRA TALHADA & 2013 \\
\hline 02019.000145/2013-60 & 696757 & D & Pesca & $27 / 02 / 2013$ & $\mathrm{R} \$ 1.868,00$ & RECIFE & 2013 \\
\hline 02019.000138/2013-68 & 696136 & D & Pesca & 28/02/2013 & $\mathrm{R} \$ 2.240,00$ & $\begin{array}{l}\text { CABO DE SANTO } \\
\text { AGOSTINHO }\end{array}$ & 2013 \\
\hline 02019.000178/2013-18 & 743288 & D & Pesca & $28 / 02 / 2013$ & $\mathrm{R} \$ 1.520,00$ & $\begin{array}{l}\text { JABOATAO DOS } \\
\text { GUARARAPES }\end{array}$ & 2013 \\
\hline 02019.000225/2013-15 & 695333 & D & Pesca & $28 / 02 / 2013$ & $\mathrm{R} \$ 1.032,00$ & GOIANA & 2013 \\
\hline 02019.000221/2013-37 & 696332 & D & Pesca & $01 / 03 / 2013$ & $\mathrm{R} \$ 2.800,00$ & PAUDALHO & 2013 \\
\hline 02019.000190/2013-14 & 695589 & D & Pesca & $01 / 03 / 2013$ & $\mathrm{R} \$ 1.520,00$ & RIO FORMOSO & 2013 \\
\hline 02019.000307/2013-60 & 696064 & D & Fauna & $04 / 03 / 2013$ & $\mathrm{R} \$ 1.000,00$ & SANTA CRUZ & 2013 \\
\hline 02019.000226/2013-60 & 695334 & D & Fauna & 05/03/2013 & $\mathrm{R} \$ 4.000,00$ & LIMOEIRO & 2013 \\
\hline 02006.000270/2013-19 & 606559 & D & Flora & $06 / 03 / 2013$ & $\mathrm{R} \$ 6.000,00$ & PETROLINA & 2013 \\
\hline 02019.000305/2013-71 & 743404 & D & Flora & 06/03/2013 & $\mathrm{R} \$ 1.500,00$ & $\begin{array}{l}\text { SAO JOSE DO } \\
\text { BELMONTE }\end{array}$ & 2013 \\
\hline 02019.000185/2013-10 & 696759 & D & Fauna & $07 / 03 / 2013$ & $\mathrm{R} \$ 14.500,00$ & ARCOVERDE & 2013 \\
\hline 02019.000309/2013-59 & 696065 & D & Flora & $07 / 03 / 2013$ & $\mathrm{R} \$ 9.600,00$ & IPUBI & 2013 \\
\hline 02019.000183/2013-12 & 743361 & D & Fauna & $08 / 03 / 2013$ & $\mathrm{R} \$ 10.500,00$ & CARUARU & 2013 \\
\hline 02019.000184/2013-67 & 696760 & D & Fauna & 08/03/2013 & $\mathrm{R} \$ 8.000,00$ & CARUARU & 2013 \\
\hline 02003.000123/2013-79 & 674878 & D & Flora & $08 / 03 / 2013$ & $\mathrm{R} \$-$ & LAGOA DO OURO & 2013 \\
\hline 02006.000325/2013-91 & 606560 & D & Flora & $13 / 03 / 2013$ & $\mathrm{R} \$ 6.000,00$ & PETROLINA & 2013 \\
\hline 02019.000308/2013-12 & 696066 & D & Flora & $14 / 03 / 2013$ & $\mathrm{R} \$ 2.400,00$ & IPUBI & 2013 \\
\hline 02019.000282/2013-02 & 696067 & D & Flora & $21 / 03 / 2013$ & $\mathrm{R} \$ 4.500,00$ & IPUBI & 2013 \\
\hline 02019.000304/2013-26 & 743405 & D & Flora & $22 / 03 / 2013$ & $\mathrm{R} \$ 111.000,00$ & ARARIPINA & 2013 \\
\hline 02019.000243/2013-05 & 369650 & D & Flora & $22 / 03 / 2013$ & $\mathrm{R} \$ 45.000,00$ & ARARIPINA & 2013 \\
\hline 02019.000275/2013-01 & 695699 & D & Flora & $22 / 03 / 2013$ & $\mathrm{R} \$ 35.000,00$ & ARARIPINA & 2013 \\
\hline
\end{tabular}




\begin{tabular}{|c|c|c|c|c|c|c|c|}
\hline 02019.000242/2013-52 & 369648 & $\mathrm{D}$ & Flora & $22 / 03 / 2013$ & $\mathrm{R} \$ 13.500,00$ & IPUBI & 2013 \\
\hline 02019.000244/2013-41 & 369649 & $\mathrm{D}$ & Flora & $22 / 03 / 2013$ & $\mathrm{R} \$ 3.000,00$ & IPUBI & 2013 \\
\hline 02019.000271/2013-14 & 695674 & $\mathrm{D}$ & Fauna & $25 / 03 / 2013$ & $\mathrm{R} \$ 9.000,00$ & RECIFE & 2013 \\
\hline 02019.000283/2013-49 & 696068 & $\mathrm{D}$ & Flora & $25 / 03 / 2013$ & $\mathrm{R} \$ 7.500,00$ & CABROBO & 2013 \\
\hline 02019.000260/2013-34 & 743496 & $\mathrm{D}$ & $\begin{array}{l}\text { Cadastro Técnico } \\
\text { Federal }\end{array}$ & 26/03/2013 & $\mathrm{R} \$ 1.800,00$ & RIBEIRAO & 2013 \\
\hline 02019.000261/2013-89 & 743497 & $\mathrm{D}$ & $\begin{array}{l}\text { Cadastro Técnico } \\
\text { Federal }\end{array}$ & $26 / 03 / 2013$ & $\mathrm{R} \$ 900,00$ & RIBEIRAO & 2013 \\
\hline 02019.000258/2013-65 & 743499 & $\mathrm{D}$ & $\begin{array}{l}\text { Cadastro Técnico } \\
\text { Federal }\end{array}$ & $27 / 03 / 2013$ & $\mathrm{R} \$ 1.800,00$ & PALMARES & 2013 \\
\hline 02019.000259/2013-18 & 743498 & $\mathrm{D}$ & $\begin{array}{l}\text { Cadastro Técnico } \\
\text { Federal }\end{array}$ & $27 / 03 / 2013$ & $\mathrm{R} \$ 900,00$ & PALMARES & 2013 \\
\hline 02019.000310/2013-83 & 743406 & $\mathrm{D}$ & Flora & $01 / 04 / 2013$ & $\mathrm{R} \$ 7.500,00$ & OURICURI & 2013 \\
\hline 02019.000285/2013-38 & 743407 & $\mathrm{D}$ & Fauna & $04 / 04 / 2013$ & $R \$ 15.500,00$ & PARNAMIRIM & 2013 \\
\hline 02019.000887/2013-95 & 695299 & $\mathrm{D}$ & Fauna & 06/04/2013 & $\mathrm{R} \$ 5.000,00$ & CARUARU & 2013 \\
\hline 02019.000311/2013-28 & 743409 & $\mathrm{D}$ & Fauna & $08 / 04 / 2013$ & $\mathrm{R} \$ 7.000,00$ & SERRA TALHADA & 2013 \\
\hline 02021.000275/2013-53 & 721753 & $\mathrm{D}$ & Controle ambiental & $10 / 04 / 2013$ & $\mathrm{R} \$ 50.000,00$ & IGARASSU & 2013 \\
\hline $02019.000321 / 2013-63$ & 695864 & $\mathrm{D}$ & Controle ambiental & $10 / 04 / 2013$ & $\mathrm{R} \$ 30.000,00$ & IGARASSU & 2013 \\
\hline 02019.000298/2013-15 & 695590 & $\mathrm{D}$ & Controle ambiental & $10 / 04 / 2013$ & $\mathrm{R} \$ 30.000,00$ & IGARASSU & 2013 \\
\hline 02021.000282/2013-55 & 721665 & $\mathrm{D}$ & Controle ambiental & $10 / 04 / 2013$ & $\mathrm{R} \$ 30.000,00$ & IGARASSU & 2013 \\
\hline 02021.000320/2013-70 & 698362 & $\mathrm{D}$ & Controle ambiental & $10 / 04 / 2013$ & $\mathrm{R} \$ 30.000,00$ & IGARASSU & 2013 \\
\hline 02019.000295/2013-73 & 696137 & $\mathrm{D}$ & Flora & $10 / 04 / 2013$ & $\mathrm{R} \$ 4.500,00$ & MOREILANDIA & 2013 \\
\hline 02019.000297/2013-62 & 696333 & $\mathrm{D}$ & Flora & $10 / 04 / 2013$ & $\mathrm{R} \$ 3.000,00$ & ARARIPINA & 2013 \\
\hline $02019.000300 / 2013-48$ & 743323 & $\mathrm{D}$ & Flora & $12 / 04 / 2013$ & $R \$ 19.200,00$ & TRINDADE & 2013 \\
\hline 02019.000296/2013-18 & 695384 & $\mathrm{D}$ & Flora & $12 / 04 / 2013$ & $\mathrm{R} \$ 4.500,00$ & IPUBI & 2013 \\
\hline 02019.000330/2013-54 & 696070 & $\mathrm{D}$ & Flora & $12 / 04 / 2013$ & $\mathrm{R} \$ 3.000,00$ & IPUBI & 2013 \\
\hline 02019.000332/2013-43 & 743411 & $\mathrm{D}$ & Flora & $13 / 04 / 2013$ & $\mathrm{R} \$ 3.000,00$ & IPUBI & 2013 \\
\hline 02019.000331/2013-07 & 743410 & $\mathrm{D}$ & Flora & $13 / 04 / 2013$ & $\mathrm{R} \$ 2.000,00$ & TRINDADE & 2013 \\
\hline 02019.000319/2013-94 & 743525 & $\mathrm{D}$ & Flora & $16 / 04 / 2013$ & $\mathrm{R} \$ 13.500,00$ & $\begin{array}{l}\text { AFOGADOS DA } \\
\text { INGAZEIRA }\end{array}$ & 2013 \\
\hline 02019.000303/2013-81 & 695610 & $\mathrm{D}$ & Flora & $16 / 04 / 2013$ & $\mathrm{R} \$ 13.500,00$ & INGAZEIRA & 2013 \\
\hline 02019.000333/2013-98 & 743413 & D & Flora & $16 / 04 / 2013$ & $\mathrm{R} \$ 12.000,00$ & $\begin{array}{l}\text { AFOGADOS DA } \\
\text { INGAZEIRA }\end{array}$ & 2013 \\
\hline 02019.000339/2013-65 & 743412 & $\mathrm{D}$ & Flora & $16 / 04 / 2013$ & $\mathrm{R} \$ 2.000,00$ & $\begin{array}{l}\text { AFOGADOS DA } \\
\text { INGAZEIRA }\end{array}$ & 2013 \\
\hline 02019.000418/2013-76 & 743415 & D & Flora & $18 / 04 / 2013$ & $\mathrm{R} \$ 220.000,00$ & $\begin{array}{l}\text { JABOATAO DOS } \\
\text { GUARARAPES }\end{array}$ & 2013 \\
\hline 02019.000419/2013-11 & 743416 & $\mathrm{D}$ & Flora & $18 / 04 / 2013$ & $\mathrm{R} \$ 30.000,00$ & EXU & 2013 \\
\hline 02019.000417/2013-21 & 743417 & $\mathrm{D}$ & Flora & $18 / 04 / 2013$ & $\mathrm{R} \$ 15.000,00$ & EXU & 2013 \\
\hline 02019.000334/2013-32 & 743418 & $\mathrm{D}$ & Flora & $19 / 04 / 2013$ & $\mathrm{R} \$ 48.000,00$ & SERRITA & 2013 \\
\hline 02013.000265/2013-17 & 694572 & $\mathrm{D}$ & Controle ambiental & $24 / 04 / 2013$ & $\mathrm{R} \$ 500.000,00$ & JOAO ALFREDO & 2013 \\
\hline 02019.000895/2013-31 & 743423 & $\mathrm{D}$ & Fauna & 03/05/2013 & $\mathrm{R} \$ 5.500,00$ & ARARIPINA & 2013 \\
\hline 02019.000493/2013-37 & 696782 & $\mathrm{D}$ & Pesca & $09 / 05 / 2013$ & $\mathrm{R} \$ 2.800,00$ & TAMANDARE & 2013 \\
\hline 02019.000494/2013-81 & 743324 & $\mathrm{D}$ & Pesca & $09 / 05 / 2013$ & $\mathrm{R} \$ 2.000,00$ & RECIFE & 2013 \\
\hline 02019.000512/2013-25 & 743501 & $\mathrm{D}$ & $\begin{array}{l}\text { Cadastro Técnico } \\
\text { Federal }\end{array}$ & $14 / 05 / 2013$ & $\mathrm{R} \$ 900,00$ & JAQUEIRA & 2013 \\
\hline 02019.000513/2013-70 & 743502 & $\mathrm{D}$ & $\begin{array}{l}\text { Cadastro Técnico } \\
\text { Federal }\end{array}$ & $15 / 05 / 2013$ & $\mathrm{R} \$ 900,00$ & CATENDE & 2013 \\
\hline 02019.000506/2013-78 & 743503 & $\mathrm{D}$ & $\begin{array}{l}\text { Cadastro Técnico } \\
\text { Federal }\end{array}$ & $15 / 05 / 2013$ & $\mathrm{R} \$ 900,00$ & CATENDE & 2013 \\
\hline 02019.000504/2013-89 & 743504 & $\mathrm{D}$ & $\begin{array}{l}\text { Cadastro Técnico } \\
\text { Federal }\end{array}$ & $15 / 05 / 2013$ & $\mathrm{R} \$ 900,00$ & CATENDE & 2013 \\
\hline 02019.000510/2013-36 & 743505 & $\mathrm{D}$ & $\begin{array}{l}\text { Cadastro Técnico } \\
\text { Federal }\end{array}$ & $15 / 05 / 2013$ & $\mathrm{R} \$ 900,00$ & CATENDE & 2013 \\
\hline 02019.000507/2013-12 & 743506 & $\mathrm{D}$ & $\begin{array}{l}\text { Cadastro Técnico } \\
\text { Federal }\end{array}$ & $15 / 05 / 2013$ & $\mathrm{R} \$ 900,00$ & BELEM DE MARIA & 2013 \\
\hline 02019.000415/2013-32 & 696334 & $\mathrm{D}$ & Fauna & $15 / 05 / 2013$ & $\mathrm{R} \$ 1.500,00$ & SANHARO & 2013 \\
\hline 02019.000508/2013-67 & 743507 & $\mathrm{D}$ & $\begin{array}{l}\text { Cadastro Técnico } \\
\text { Federal }\end{array}$ & $16 / 05 / 2013$ & $\mathrm{R} \$ 900,00$ & CUPIRA & 2013 \\
\hline 02019.000511/2013-81 & 743508 & D & $\begin{array}{l}\text { Cadastro Técnico } \\
\text { Federal }\end{array}$ & $16 / 05 / 2013$ & $\mathrm{R} \$ 900,00$ & CARPINA & 2013 \\
\hline 02019.000559/2013-99 & 695385 & $\mathrm{D}$ & Controle ambiental & $20 / 05 / 2013$ & $\mathrm{R} \$ 25.000,00$ & VERDEJANTE & 2013 \\
\hline 02019.000657/2013-26 & 695675 & $\mathrm{D}$ & Controle ambiental & $21 / 05 / 2013$ & $\mathrm{R} \$ 30.000,00$ & ARCOVERDE & 2013 \\
\hline
\end{tabular}




\begin{tabular}{|c|c|c|c|c|c|c|c|}
\hline 02019.000509/2013-10 & 743509 & D & Controle ambiental & $21 / 05 / 2013$ & $\mathrm{R} \$ 20.000,00$ & CUSTODIA & 2013 \\
\hline 02019.000581/2013-39 & 696335 & D & Flora & 21/05/2013 & $\mathrm{R} \$ 13.000,00$ & ARCOVERDE & 2013 \\
\hline 02019.000591/2013-74 & 743641 & D & Controle ambiental & $22 / 05 / 2013$ & $\mathrm{R} \$ 10.000,00$ & ARCOVERDE & 2013 \\
\hline 02019.000893/2013-42 & 743419 & $D$ & Fauna & 22/05/2013 & $\mathrm{R} \$ 15.000,00$ & ARARIPINA & 2013 \\
\hline 02019.000553/2013-11 & 695297 & D & Flora & 22/05/2013 & $\mathrm{R} \$ 9.900,00$ & SERRA TALHADA & 2013 \\
\hline 02019.000604/2013-13 & 695700 & $D$ & Controle ambiental & 23/05/2013 & $\mathrm{R} \$ 10.000,00$ & CUSTODIA & 2013 \\
\hline 02019.000558/2013-44 & 695386 & D & Controle ambiental & $23 / 05 / 2013$ & $\mathrm{R} \$ 10.000,00$ & CUSTODIA & 2013 \\
\hline 02019.000894/2013-97 & 743420 & $D$ & Fauna & 23/05/2013 & $\mathrm{R} \$ 7.500,00$ & ARARIPINA & 2013 \\
\hline 02019.000899/2013-10 & 743421 & D & Fauna & 23/05/2013 & $\mathrm{R} \$ 6.000,00$ & ARARIPINA & 2013 \\
\hline 02019.000505/2013-23 & 743510 & D & Flora & 23/05/2013 & $\mathrm{R} \$ 5.400,00$ & CUSTODIA & 2013 \\
\hline 02019.000585/2013-17 & 695866 & D & Flora & $24 / 05 / 2013$ & $\mathrm{R} \$ 16.000,00$ & IBIMIRIM & 2013 \\
\hline 02019.000549/2013-53 & 743445 & D & Flora & 24/05/2013 & $\mathrm{R} \$ 3.000,00$ & CUSTODIA & 2013 \\
\hline 02019.000548/2013-17 & 743444 & $\mathrm{D}$ & Flora & $24 / 05 / 2013$ & $\mathrm{R} \$ 1.000,00$ & CUSTODIA & 2013 \\
\hline 02019.000624/2013-86 & 507145 & $D$ & Flora & $26 / 05 / 2013$ & $\mathrm{R} \$ 11.400,00$ & OURICURI & 2013 \\
\hline 02019.000655/2013-37 & 695676 & D & Controle ambiental & $27 / 05 / 2013$ & $\mathrm{R} \$ 30.000,00$ & SALGUEIRO & 2013 \\
\hline 02019.000560/2013-13 & 743326 & D & Controle ambiental & $27 / 05 / 2013$ & $\mathrm{R} \$ 30.000,00$ & SALGUEIRO & 2013 \\
\hline 02019.000551/2013-22 & 695296 & D & Controle ambiental & $27 / 05 / 2013$ & $\mathrm{R} \$ 10.000,00$ & SALGUEIRO & 2013 \\
\hline 02019.000503/2013-34 & 743258 & $\mathrm{D}$ & Fauna & $27 / 05 / 2013$ & $\mathrm{R} \$ 11.000,00$ & RECIFE & 2013 \\
\hline 02019.000582/2013-83 & 696336 & $\mathrm{D}$ & Flora & $27 / 05 / 2013$ & $\mathrm{R} \$ 7.000,00$ & ARCOVERDE & 2013 \\
\hline 02019.000552/2013-77 & 695335 & D & Controle ambiental & $28 / 05 / 2013$ & $\mathrm{R} \$ 10.000,00$ & SALGUEIRO & 2013 \\
\hline 02019.000848/2013-98 & 695701 & $\mathrm{D}$ & Controle ambiental & 29/05/2013 & $\mathrm{R} \$ 10.000,00$ & SERRITA & 2013 \\
\hline 02019.000607/2013-49 & 507146 & D & Controle ambiental & 29/05/2013 & $\mathrm{R} \$ 10.000,00$ & SERRITA & 2013 \\
\hline 02019.000586/2013-61 & 695867 & D & Controle ambiental & $29 / 05 / 2013$ & $\mathrm{R} \$ 10.000,00$ & SERRITA & 2013 \\
\hline 02019.000656/2013-81 & 695677 & $\mathrm{D}$ & Flora & $30 / 05 / 2013$ & $\mathrm{R} \$ 4.000,00$ & SALGUEIRO & 2013 \\
\hline 02006.000571/2013-42 & 548825 & D & Fauna & 05/06/2013 & $\mathrm{R} \$ 6.500,00$ & PETROLINA & 2013 \\
\hline 02019.000896/2013-86 & 743424 & D & Fauna & 07/06/2013 & $\mathrm{R} \$ 165.000,00$ & TRIUNFO & 2013 \\
\hline 02019.000642/2013-68 & 743259 & D & Fauna & $08 / 06 / 2013$ & $\mathrm{R} \$ 37.000,00$ & GARANHUNS & 2013 \\
\hline 02019.000641/2013-13 & 743260 & D & Fauna & 08/06/2013 & $\mathrm{R} \$ 4.500,00$ & GARANHUNS & 2013 \\
\hline 02019.000598/2013-96 & 696138 & D & Fauna & 08/06/2013 & $\mathrm{R} \$ 4.000,00$ & GARANHUNS & 2013 \\
\hline 02019.000630/2013-33 & 507069 & D & Fauna & 08/06/2013 & $\mathrm{R} \$ 3.400,00$ & GARANHUNS & 2013 \\
\hline 02019.001329/2013-47 & 695869 & D & Fauna & 08/06/2013 & $\mathrm{R} \$ 3.000,00$ & GARANHUNS & 2013 \\
\hline 02019.000712/2013-88 & 695678 & D & Fauna & 08/06/2013 & $\mathrm{R} \$ 2.000,00$ & GARANHUNS & 2013 \\
\hline 02019.000627/2013-10 & 743446 & D & Fauna & 08/06/2013 & $\mathrm{R} \$ 2.000,00$ & GARANHUNS & 2013 \\
\hline 02019.000633/2013-77 & 695611 & D & Fauna & 08/06/2013 & $\mathrm{R} \$ 2.000,00$ & GARANHUNS & 2013 \\
\hline 02019.000731/2013-12 & 696244 & D & Fauna & 08/06/2013 & $\mathrm{R} \$ 1.000,00$ & GARANHUNS & 2013 \\
\hline 02019.000727/2013-46 & 696245 & D & Fauna & 08/06/2013 & $\mathrm{R} \$ 1.000,00$ & GARANHUNS & 2013 \\
\hline 02019.000609/2013-38 & 695868 & D & Fauna & $08 / 06 / 2013$ & $\mathrm{R} \$ 500,00$ & GARANHUNS & 2013 \\
\hline 02019.000663/2013-83 & 696337 & D & Fauna & 08/06/2013 & $\mathrm{R} \$ 500,00$ & GARANHUNS & 2013 \\
\hline 02019.000662/2013-39 & 696338 & D & Fauna & $08 / 06 / 2013$ & $\mathrm{R} \$ 500,00$ & GARANHUNS & 2013 \\
\hline 02019.000729/2013-35 & 696247 & D & Fauna & 09/06/2013 & $\mathrm{R} \$ 8.500,00$ & CARUARU & 2013 \\
\hline 02019.000659/2013-15 & 696342 & D & Fauna & 09/06/2013 & $\mathrm{R} \$ 3.000,00$ & CARUARU & 2013 \\
\hline 02019.000601/2013-71 & 696141 & D & Fauna & 09/06/2013 & $\mathrm{R} \$ 2.000,00$ & CARUARU & 2013 \\
\hline 02019.000728/2013-91 & 696248 & D & Fauna & 09/06/2013 & $\mathrm{R} \$ 2.000,00$ & CARUARU & 2013 \\
\hline 02019.000661/2013-94 & 696339 & D & Fauna & 09/06/2013 & $\mathrm{R} \$ 1.000,00$ & CARUARU & 2013 \\
\hline 02019.000599/2013-31 & 696139 & D & Fauna & 09/06/2013 & $\mathrm{R} \$ 500,00$ & CARUARU & 2013 \\
\hline 02019.000600/2013-27 & 696140 & D & Fauna & 09/06/2013 & $\mathrm{R} \$ 500,00$ & CARUARU & 2013 \\
\hline 02019.000660/2013-40 & 696341 & D & Fauna & 09/06/2013 & $\mathrm{R} \$ 500,00$ & CARUARU & 2013 \\
\hline 02019.000636/2013-19 & 743511 & $D$ & $\begin{array}{l}\text { Cadastro Técnico } \\
\text { Federal }\end{array}$ & $10 / 06 / 2013$ & $\mathrm{R} \$ 900,00$ & GLORIA DO GOITA & 2013 \\
\hline 02019.000637/2013-55 & 743512 & $\mathrm{D}$ & $\begin{array}{l}\text { Cadastro Técnico } \\
\text { Federal }\end{array}$ & $10 / 06 / 2013$ & $\mathrm{R} \$ 900,00$ & FEIRA NOVA & 2013 \\
\hline 02019.000631/2013-88 & 507072 & D & Fauna & $10 / 06 / 2013$ & $\mathrm{R} \$ 99.000,00$ & AGUAS BELAS & 2013 \\
\hline 02019.000713/2013-22 & 695679 & D & Fauna & $10 / 06 / 2013$ & $\mathrm{R} \$ 22.000,00$ & AGUA PRETA & 2013 \\
\hline 02019.000632/2013-22 & 507073 & D & Fauna & $10 / 06 / 2013$ & $\mathrm{R} \$ 12.500,00$ & AGUAS BELAS & 2013 \\
\hline 02019.000634/2013-11 & 695612 & D & Fauna & $10 / 06 / 2013$ & $\mathrm{R} \$ 5.000,00$ & AGUAS BELAS & 2013 \\
\hline 02019.000640/2013-79 & 696108 & D & Fauna & $10 / 06 / 2013$ & $\mathrm{R} \$ 4.000,00$ & AGUAS BELAS & 2013 \\
\hline 02019.000608/2013-93 & 695871 & D & Fauna & $10 / 06 / 2013$ & $\mathrm{R} \$ 3.000,00$ & AGUAS BELAS & 2013 \\
\hline 02019.000628/2013-64 & 743448 & D & Fauna & $10 / 06 / 2013$ & $\mathrm{R} \$ 2.000,00$ & AGUAS BELAS & 2013 \\
\hline 02019.000726/2013-00 & 696249 & $\mathrm{D}$ & Fauna & $10 / 06 / 2013$ & $\mathrm{R} \$ 2.000,00$ & AGUAS BELAS & 2013 \\
\hline
\end{tabular}




\begin{tabular}{|c|c|c|c|c|c|c|c|}
\hline 02019.000605/2013-50 & 696143 & D & Fauna & $10 / 06 / 2013$ & $\mathrm{R} \$ 1.000,00$ & AGUAS BELAS & 2013 \\
\hline 02019.000629/2013-17 & 743449 & D & Fauna & $10 / 06 / 2013$ & $\mathrm{R} \$ 1.000,00$ & AGUAS BELAS & 2013 \\
\hline 02019.000602/2013-16 & 696142 & D & Fauna & $10 / 06 / 2013$ & $R \$ 500,00$ & AGUAS BELAS & 2013 \\
\hline 02019.000610/2013-62 & 695870 & D & Fauna & $10 / 06 / 2013$ & $R \$ 500,00$ & AGUAS BELAS & 2013 \\
\hline 02019.000730/2013-60 & 696250 & $\mathrm{D}$ & Fauna & $10 / 06 / 2013$ & $\mathrm{R} \$ 500,00$ & AGUAS BELAS & 2013 \\
\hline 02019.000638/2013-08 & 743513 & D & $\begin{array}{l}\text { Cadastro Técnico } \\
\text { Federal }\end{array}$ & $11 / 06 / 2013$ & $\mathrm{R} \$ 900,00$ & RIACHO DAS ALMAS & 2013 \\
\hline 02019.000639/2013-44 & 743514 & D & $\begin{array}{l}\text { Cadastro Técnico } \\
\text { Federal }\end{array}$ & $11 / 06 / 2013$ & $\mathrm{R} \$ 900,00$ & RIACHO DAS ALMAS & 2013 \\
\hline 02019.000733/2013-01 & 743515 & D & $\begin{array}{l}\text { Cadastro Técnico } \\
\text { Federal }\end{array}$ & $27 / 06 / 2013$ & $\mathrm{R} \$ 1.800,00$ & CUSTODIA & 2013 \\
\hline 02019.000734/2013-48 & 743516 & D & $\begin{array}{l}\text { Cadastro Técnico } \\
\text { Federal }\end{array}$ & $02 / 07 / 2013$ & $\mathrm{R} \$ 900,00$ & PARNAMIRIM & 2013 \\
\hline 02019.000781/2013-91 & 743450 & D & Controle ambiental & $02 / 07 / 2013$ & $\mathrm{R} \$ 30.000,00$ & SAO CAITANO & 2013 \\
\hline 02019.000840/2013-21 & 695872 & D & Controle ambiental & 02/07/2013 & $\mathrm{R} \$ 20.000,00$ & SAO CAITANO & 2013 \\
\hline 02019.000799/2013-93 & 695591 & D & Controle ambiental & $02 / 07 / 2013$ & $\mathrm{R} \$ 20.000,00$ & SAO CAITANO & 2013 \\
\hline 02019.000771/2013-56 & 507074 & D & Controle ambiental & $02 / 07 / 2013$ & $\mathrm{R} \$ 20.000,00$ & SAO CAITANO & 2013 \\
\hline 02019.000778/2013-78 & 696667 & D & Controle ambiental & $02 / 07 / 2013$ & $\mathrm{R} \$ 20.000,00$ & SAO CAITANO & 2013 \\
\hline 02019.000776/2013-89 & 695387 & D & Controle ambiental & 02/07/2013 & $\mathrm{R} \$ 20.000,00$ & SAO CAITANO & 2013 \\
\hline 02019.000857/2013-89 & 743526 & D & Flora & $02 / 07 / 2013$ & $\mathrm{R} \$ 23.829,00$ & PETROLINA & 2013 \\
\hline 02019.000779/2013-12 & 696668 & D & Controle ambiental & 03/07/2013 & $\mathrm{R} \$ 20.000,00$ & SERTANIA & 2013 \\
\hline $02019.000777 / 2013-23$ & 695388 & D & Controle ambiental & $03 / 07 / 2013$ & $\mathrm{R} \$ 20.000,00$ & SERTANIA & 2013 \\
\hline 02019.000783/2013-81 & 743452 & D & Controle ambiental & 03/07/2013 & $\mathrm{R} \$ 20.000,00$ & SERTANIA & 2013 \\
\hline 02019.000828/2013-17 & 743681 & D & Flora & $03 / 07 / 2013$ & $\mathrm{R} \$ 25.914,00$ & PETROLINA & 2013 \\
\hline 02019.000923/2013-11 & 743425 & D & Flora & $03 / 07 / 2013$ & $\mathrm{R} \$ 2.250,00$ & IBIMIRIM & 2013 \\
\hline 02019.000735/2013-92 & 743517 & D & $\begin{array}{l}\text { Cadastro Técnico } \\
\text { Federal }\end{array}$ & $04 / 07 / 2013$ & $\mathrm{R} \$ 900,00$ & TRIUNFO & 2013 \\
\hline 02019.000736/2013-37 & 743518 & D & $\begin{array}{l}\text { Cadastro Técnico } \\
\text { Federal }\end{array}$ & $04 / 07 / 2013$ & $\mathrm{R} \$ 900,00$ & $\begin{array}{l}\text { SANTA CRUZ DA } \\
\text { BAIXA VERDE }\end{array}$ & 2013 \\
\hline 02019.000798/2013-49 & 507075 & D & Controle ambiental & $04 / 07 / 2013$ & $R \$ 50.000,00$ & SAO CAITANO & 2013 \\
\hline 02019.000841/2013-76 & 695873 & D & Controle ambiental & $04 / 07 / 2013$ & $\mathrm{R} \$ 20.000,00$ & CARUARU & 2013 \\
\hline 02019.000780/2013-47 & 696669 & D & Controle ambiental & $04 / 07 / 2013$ & $\mathrm{R} \$ 20.000,00$ & SAO CAITANO & 2013 \\
\hline 02019.000775/2013-34 & 695298 & D & Flora & $04 / 07 / 2013$ & $\mathrm{R} \$ 6.387,00$ & PETROLINA & 2013 \\
\hline 02019.000837/2013-16 & 696109 & D & Flora & $05 / 07 / 2013$ & $\mathrm{R} \$ 23.909,10$ & PETROLINA & 2013 \\
\hline 02019.000868/2013-69 & 743527 & D & Flora & 08/07/2013 & $\mathrm{R} \$ 4.461,00$ & OURICURI & 2013 \\
\hline 02019.000843/2013-65 & 743643 & D & Flora & 09/07/2013 & $\mathrm{R} \$ 6.143,70$ & SERRITA & 2013 \\
\hline 02019.000827/2013-72 & 743682 & D & Flora & 09/07/2013 & $\mathrm{R} \$ 4.243,50$ & EXU & 2013 \\
\hline 02019.000825/2013-83 & 696344 & D & Flora & $10 / 07 / 2013$ & $\mathrm{R} \$ 24.777,00$ & SALGUEIRO & 2013 \\
\hline 02019.000819/2013-26 & 743293 & D & Flora & $10 / 07 / 2013$ & $\mathrm{R} \$ 5.000,00$ & VERDEJANTE & 2013 \\
\hline 02019.000782/2013-36 & 743325 & $\mathrm{D}$ & Flora & $11 / 07 / 2013$ & $\mathrm{R} \$ 15.300,00$ & CUSTODIA & 2013 \\
\hline 02019.000820/2013-51 & 695336 & $\mathrm{D}$ & Flora & $12 / 07 / 2013$ & $\mathrm{R} \$ 54.000,00$ & SALGUEIRO & 2013 \\
\hline 02019.000847/2013-43 & 695389 & D & Flora & $17 / 07 / 2013$ & $\mathrm{R} \$ 12.600,00$ & ARARIPINA & 2013 \\
\hline 02019.000922/2013-76 & 696075 & D & Flora & $17 / 07 / 2013$ & $\mathrm{R} \$ 3.600,00$ & ARARIPINA & 2013 \\
\hline 02019.000831/2013-31 & 743519 & D & Fauna & $18 / 07 / 2013$ & $\mathrm{R} \$ 24.000,00$ & $\begin{array}{l}\text { JABOATAO DOS } \\
\text { GUARARAPES }\end{array}$ & 2013 \\
\hline 02019.000846/2013-07 & 696110 & D & Fauna & $18 / 07 / 2013$ & $R \$ 12.000,00$ & $\begin{array}{l}\text { JABOATAO DOS } \\
\text { GUARARAPES }\end{array}$ & 2013 \\
\hline 02019.000849/2013-32 & 507147 & D & Flora & $19 / 07 / 2013$ & $\mathrm{R} \$ 1.000,00$ & ARARIPINA & 2013 \\
\hline 02001.000323/2013-41 & 717660 & D & $\begin{array}{l}\text { Cadastro Técnico } \\
\text { Federal }\end{array}$ & $22 / 07 / 2013$ & $\mathrm{R} \$ 30.100,00$ & RECIFE & 2013 \\
\hline 02019.000853/2013-09 & 696671 & D & Flora & $22 / 07 / 2013$ & $\mathrm{R} \$ 12.000,00$ & ARARIPINA & 2013 \\
\hline 02019.000852/2013-56 & 743294 & D & Flora & $22 / 07 / 2013$ & $\mathrm{R} \$ 10.000,00$ & ARARIPINA & 2013 \\
\hline 02019.000880/2013-73 & 743520 & D & $\begin{array}{l}\text { Cadastro Técnico } \\
\text { Federal }\end{array}$ & $30 / 07 / 2013$ & $\mathrm{R} \$ 5.000,00$ & SAO JOSE DO EGITO & 2013 \\
\hline 02019.000888/2013-30 & 743295 & D & $\begin{array}{l}\text { Cadastro Técnico } \\
\text { Federal }\end{array}$ & $30 / 07 / 2013$ & $\mathrm{R} \$ 900,00$ & SAO JOSE DO EGITO & 2013 \\
\hline 02019.000921/2013-21 & 696076 & D & Fauna & $30 / 07 / 2013$ & $\mathrm{R} \$ 5.500,00$ & EXU & 2013 \\
\hline 02019.000877/2013-50 & 743721 & D & $\begin{array}{l}\text { Cadastro Técnico } \\
\text { Federal }\end{array}$ & $31 / 07 / 2013$ & $\mathrm{R} \$ 900,00$ & TABIRA & 2013 \\
\hline 02019.000890/2013-17 & 743297 & D & $\begin{array}{l}\text { Cadastro Técnico } \\
\text { Federal }\end{array}$ & $31 / 07 / 2013$ & $\mathrm{R} \$ 900,00$ & CARNAIBA & 2013 \\
\hline
\end{tabular}




\begin{tabular}{|c|c|c|c|c|c|c|c|}
\hline 02019.000889/2013-84 & 743296 & D & $\begin{array}{l}\text { Cadastro Técnico } \\
\text { Federal }\end{array}$ & $01 / 08 / 2013$ & $\mathrm{R} \$ 900,00$ & TABIRA & 2013 \\
\hline 02019.000879/2013-49 & 743722 & D & $\begin{array}{l}\text { Cadastro Técnico } \\
\text { Federal }\end{array}$ & $01 / 08 / 2013$ & $\mathrm{R} \$ 900,00$ & TABIRA & 2013 \\
\hline 02019.000878/2013-02 & 743723 & D & $\begin{array}{l}\text { Cadastro Técnico } \\
\text { Federal }\end{array}$ & $01 / 08 / 2013$ & $\mathrm{R} \$ 900,00$ & CARNAIBA & 2013 \\
\hline 02019.000892/2013-06 & 743683 & D & Fauna & $01 / 08 / 2013$ & $\mathrm{R} \$ 4.000,00$ & LIMOEIRO & 2013 \\
\hline 02019.001015/2013-44 & 743687 & D & Fauna & $01 / 08 / 2013$ & $\mathrm{R} \$ 1.500,00$ & GOIANA & 2013 \\
\hline 02019.000864/2013-81 & 695337 & D & Fauna & $01 / 08 / 2013$ & $\mathrm{R} \$ 1.000,00$ & LIMOEIRO & 2013 \\
\hline 02019.000891/2013-53 & 743298 & D & $\begin{array}{l}\text { Cadastro Técnico } \\
\text { Federal }\end{array}$ & $02 / 08 / 2013$ & $\mathrm{R} \$ 900,00$ & IGUARACI & 2013 \\
\hline 02019.000946/2013-25 & 743426 & D & Flora & $02 / 08 / 2013$ & $\mathrm{R} \$ 660.000,00$ & $\begin{array}{l}\text { JABOATAO DOS } \\
\text { GUARARAPES }\end{array}$ & 2013 \\
\hline 02019.000948/2013-14 & 696077 & $\mathrm{D}$ & Flora & 06/08/2013 & $\mathrm{R} \$ 3.000,00$ & OURICURI & 2013 \\
\hline 02019.000925/2013-18 & 695339 & D & Flora & $06 / 08 / 2013$ & $\mathrm{R} \$ 2.000,00$ & SALGUEIRO & 2013 \\
\hline 02019.001132/2013-16 & 743261 & D & Fauna & $07 / 08 / 2013$ & $\mathrm{R} \$ 137.000,00$ & SAO CAITANO & 2013 \\
\hline 02019.000945/2013-81 & 743427 & D & Flora & $07 / 08 / 2013$ & $\mathrm{R} \$ 15.000,00$ & OURICURI & 2013 \\
\hline 02019.000943/2013-91 & 696111 & D & Flora & $07 / 08 / 2013$ & $\mathrm{R} \$ 7.500,00$ & OURICURI & 2013 \\
\hline 02019.000944/2013-36 & 696112 & D & Flora & $07 / 08 / 2013$ & $\mathrm{R} \$ 5.400,00$ & ARARIPINA & 2013 \\
\hline 02019.000924/2013-65 & 695340 & D & Flora & 08/08/2013 & $\mathrm{R} \$ 14.000,00$ & ARARIPINA & 2013 \\
\hline 02006.001289/2013-82 & 548829 & D & Fauna & $13 / 08 / 2013$ & $\mathrm{R} \$ 1.500,00$ & PETROLINA & 2013 \\
\hline 02019.001011/2013-66 & 743299 & D & $\begin{array}{l}\text { Cadastro Técnico } \\
\text { Federal }\end{array}$ & $15 / 08 / 2013$ & $\mathrm{R} \$ 900,00$ & EXU & 2013 \\
\hline 02019.000951/2013-38 & 743724 & D & $\begin{array}{l}\text { Cadastro Técnico } \\
\text { Federal }\end{array}$ & $16 / 08 / 2013$ & $\mathrm{R} \$ 900,00$ & OURICURI & 2013 \\
\hline 02019.000919/2013-52 & 466541 & D & Fauna & $18 / 08 / 2013$ & $\mathrm{R} \$ 16.500,00$ & PAULISTA & 2013 \\
\hline 02019.001012/2013-19 & 743300 & D & $\begin{array}{l}\text { Cadastro Técnico } \\
\text { Federal }\end{array}$ & $19 / 08 / 2013$ & $\mathrm{R} \$ 900,00$ & ARARIPINA & 2013 \\
\hline 02019.000953/2013-27 & 743725 & D & $\begin{array}{l}\text { Cadastro Técnico } \\
\text { Federal }\end{array}$ & $19 / 08 / 2013$ & $\mathrm{R} \$ 900,00$ & ARARIPINA & 2013 \\
\hline 02019.001013/2013-55 & 743301 & D & $\begin{array}{l}\text { Cadastro Técnico } \\
\text { Federal }\end{array}$ & $19 / 08 / 2013$ & $\mathrm{R} \$ 900,00$ & ARARIPINA & 2013 \\
\hline 02019.001014/2013-08 & 743685 & D & Fauna & $19 / 08 / 2013$ & $\mathrm{R} \$ 16.500,00$ & LIMOEIRO & 2013 \\
\hline 02019.000939/2013-23 & 695300 & D & Fauna & $20 / 08 / 2013$ & $\mathrm{R} \$ 5.500,00$ & $\begin{array}{l}\text { SANTA MARIA DO } \\
\text { CAMBUCA }\end{array}$ & 2013 \\
\hline 02019.000938/2013-89 & 743453 & D & Fauna & $20 / 08 / 2013$ & $\mathrm{R} \$ 3.000,00$ & BOM JARDIM & 2013 \\
\hline 02019.000941/2013-01 & 695341 & D & Fauna & $20 / 08 / 2013$ & $\mathrm{R} \$ 3.000,00$ & BEZERROS & 2013 \\
\hline 02019.000947/2013-70 & 743428 & D & Flora & $20 / 08 / 2013$ & $\mathrm{R} \$ 3.150,00$ & PETROLINA & 2013 \\
\hline 02019.000931/2013-67 & 696144 & D & Fauna & $21 / 08 / 2013$ & $\mathrm{R} \$ 15.000,00$ & $\begin{array}{l}\text { JABOATAO DOS } \\
\text { GUARARAPES }\end{array}$ & 2013 \\
\hline 02019.000942/2013-47 & 506796 & D & Fauna & $21 / 08 / 2013$ & $\mathrm{R} \$ 5.000,00$ & CARUARU & 2013 \\
\hline 02019.000937/2013-34 & 507148 & D & Fauna & $21 / 08 / 2013$ & $\mathrm{R} \$ 2.000,00$ & CONDADO & 2013 \\
\hline 02019.001069/2013-18 & 541767 & D & Fauna & $22 / 08 / 2013$ & $\mathrm{R} \$ 4.500,00$ & CARUARU & 2013 \\
\hline 02019.000974/2013-42 & 695875 & $\mathrm{D}$ & Controle ambiental & $23 / 08 / 2013$ & $\mathrm{R} \$ 30.000,00$ & SALGUEIRO & 2013 \\
\hline 02019.001104/2013-91 & 696078 & D & Fauna & $23 / 08 / 2013$ & $\mathrm{R} \$ 7.000,00$ & $\begin{array}{l}\text { BELEM DE SAO } \\
\text { FRANCISCO }\end{array}$ & 2013 \\
\hline 02019.000952/2013-82 & 743726 & D & Fauna & $23 / 08 / 2013$ & $\mathrm{R} \$ 5.000,00$ & $\begin{array}{l}\text { CABO DE SANTO } \\
\text { AGOSTINHO }\end{array}$ & 2013 \\
\hline 02019.001064/2013-87 & 507076 & $\mathrm{D}$ & Controle ambiental & $02 / 09 / 2013$ & $R \$ 10.500,00$ & IPOJUCA & 2013 \\
\hline 02016.001037/2013-34 & 2986 & $E$ & Controle ambiental & $02 / 09 / 2013$ & $R \$ 10.500,00$ & IGARASSU & 2013 \\
\hline 02021.000778/2013-29 & 721759 & D & Controle ambiental & $02 / 09 / 2013$ & $R \$ 10.500,00$ & IGARASSU & 2013 \\
\hline 02019.001063/2013-32 & 696145 & D & Controle ambiental & $02 / 09 / 2013$ & $\mathrm{R} \$ 2.500,00$ & IPOJUCA & 2013 \\
\hline 02016.001032/2013-10 & 689227 & D & Controle ambiental & $02 / 09 / 2013$ & $\mathrm{R} \$ 500,00$ & IGARASSU & 2013 \\
\hline 02019.001025/2013-80 & 743686 & D & Fauna & 03/09/2013 & $\mathrm{R} \$ 1.500,00$ & $\begin{array}{l}\text { SAO VICENTE } \\
\text { FERRER }\end{array}$ & 2013 \\
\hline 02019.001072/2013-23 & 466543 & D & Fauna & $04 / 09 / 2013$ & $\mathrm{R} \$ 1.000,00$ & RECIFE & 2013 \\
\hline 02019.001057/2013-85 & 696226 & $\mathrm{D}$ & Pesca & $04 / 09 / 2013$ & $R \$ 10.340,00$ & RECIFE & 2013 \\
\hline 02019.001024/2013-35 & 507149 & D & Fauna & 05/09/2013 & $\mathrm{R} \$ 9.500,00$ & BONITO & 2013 \\
\hline 02019.001065/2013-21 & 507077 & $\mathrm{D}$ & Controle ambiental & 09/09/2013 & $\mathrm{R} \$ 50.000,00$ & RECIFE & 2013 \\
\hline 02019.001098/2013-71 & 696080 & $\mathrm{D}$ & Flora & 09/09/2013 & $\mathrm{R} \$ 1.000,00$ & PARNAMIRIM & 2013 \\
\hline 02019.001086/2013-47 & 466544 & $\mathrm{D}$ & Fauna & $10 / 09 / 2013$ & $\mathrm{R} \$ 5.000,00$ & OLINDA & 2013 \\
\hline 02018.001451/2013-23 & 741003 & D & Fauna & $11 / 09 / 2013$ & $\mathrm{R} \$ 5.000,00$ & RECIFE & 2013 \\
\hline
\end{tabular}




\begin{tabular}{|c|c|c|c|c|c|c|c|}
\hline 02018.001452/2013-78 & 741004 & D & Pesca & $13 / 09 / 2013$ & $\mathrm{R} \$ 3.000,00$ & RECIFE & 2013 \\
\hline 02019.001077/2013-56 & 696228 & D & Flora & $23 / 09 / 2013$ & $\mathrm{R} \$ 3.000,00$ & VERDEJANTE & 2013 \\
\hline 02019.001124/2013-61 & 743429 & D & Flora & $24 / 09 / 2013$ & $\mathrm{R} \$ 12.000,00$ & SERTANIA & 2013 \\
\hline 02019.001181/2013-41 & 743841 & D & Flora & $27 / 09 / 2013$ & $\mathrm{R} \$ 5.500,00$ & PETROLINA & 2013 \\
\hline 02019.001106/2013-80 & 743728 & D & Controle ambiental & $02 / 10 / 2013$ & $\mathrm{R} \$ 900,00$ & GARANHUNS & 2013 \\
\hline 02019.001118/2013-12 & 743729 & D & Controle ambiental & $10 / 10 / 2013$ & $\mathrm{R} \$ 20.000,00$ & RECIFE & 2013 \\
\hline 02019.001205/2013-61 & 743430 & D & Flora & $21 / 10 / 2013$ & $\mathrm{R} \$ 10.000,00$ & SERRITA & 2013 \\
\hline 02019.001174/2013-49 & 696672 & D & Flora & $22 / 10 / 2013$ & $\mathrm{R} \$ 2.100,00$ & PARNAMIRIM & 2013 \\
\hline 02019.001324/2013-14 & 507150 & D & Flora & $23 / 10 / 2013$ & $\mathrm{R} \$ 4.000,00$ & TRINDADE & 2013 \\
\hline 02019.001276/2013-64 & 743262 & D & Pesca & $24 / 10 / 2013$ & $\mathrm{R} \$ 1.120,00$ & RECIFE & 2013 \\
\hline 02019.001175/2013-93 & 696673 & D & Flora & $25 / 10 / 2013$ & $\mathrm{R} \$ 11.700,00$ & ARCOVERDE & 2013 \\
\hline 02019.001206/2013-14 & 743431 & D & Fauna & 29/10/2013 & $\mathrm{R} \$ 9.000,00$ & SALGUEIRO & 2013 \\
\hline 02019.001331/2013-16 & 743433 & D & Flora & 29/10/2013 & $\mathrm{R} \$ 8.100,00$ & PARNAMIRIM & 2013 \\
\hline 02019.001207/2013-51 & 743434 & D & Flora & $30 / 10 / 2013$ & $\mathrm{R} \$ 4.500,00$ & EXU & 2013 \\
\hline 02019.001180/2013-04 & 743843 & D & Flora & $01 / 11 / 2013$ & $\mathrm{R} \$ 500,00$ & PARNAMIRIM & 2013 \\
\hline 02019.001332/2013-61 & 743435 & D & Flora & $05 / 11 / 2013$ & $\mathrm{R} \$ 15.000,00$ & EXU & 2013 \\
\hline 02019.001338/2013-38 & 743844 & $\mathrm{D}$ & Fauna & $15 / 11 / 2013$ & $\mathrm{R} \$ 4.000,00$ & IGUARACI & 2013 \\
\hline 02019.001252/2013-13 & 466545 & D & Fauna & $21 / 11 / 2013$ & $\mathrm{R} \$-$ & RECIFE & 2013 \\
\hline 02019.001363/2013-11 & 743967 & D & Controle ambiental & $25 / 11 / 2013$ & $\mathrm{R} \$ 3.000,00$ & SALGUEIRO & 2013 \\
\hline 02019.001333/2013-13 & 743437 & D & Fauna & $25 / 11 / 2013$ & $\mathrm{R} \$ 95.000,00$ & IGUARACI & 2013 \\
\hline 02019.001344/2013-95 & 743965 & D & Fauna & $25 / 11 / 2013$ & $\mathrm{R} \$ 9.000,00$ & IGUARACI & 2013 \\
\hline 02019.001339/2013-82 & 743845 & D & Fauna & $25 / 11 / 2013$ & $\mathrm{R} \$ 6.000,00$ & IGUARACI & 2013 \\
\hline 02019.001340/2013-15 & 743846 & D & Fauna & $25 / 11 / 2013$ & $\mathrm{R} \$ 3.000,00$ & IGUARACI & 2013 \\
\hline 02019.001350/2013-42 & 743962 & D & Fauna & $25 / 11 / 2013$ & $\mathrm{R} \$ 2.000,00$ & IGUARACI & 2013 \\
\hline 02019.001343/2013-41 & 743964 & $\mathrm{D}$ & Fauna & $25 / 11 / 2013$ & $\mathrm{R} \$ 2.000,00$ & IGUARACI & 2013 \\
\hline 02019.001334/2013-50 & 743438 & $\mathrm{D}$ & Fauna & $25 / 11 / 2013$ & $\mathrm{R} \$ 1.000,00$ & IGUARACI & 2013 \\
\hline $02019.001341 / 2013-51$ & 743847 & $\mathrm{D}$ & Fauna & $25 / 11 / 2013$ & $\mathrm{R} \$ 1.000,00$ & IGUARACI & 2013 \\
\hline 02019.001362/2013-77 & 743966 & $\mathrm{D}$ & Flora & $25 / 11 / 2013$ & $\mathrm{R} \$ 1.000,00$ & SALGUEIRO & 2013 \\
\hline 02019.001307/2013-87 & 743731 & D & $\begin{array}{l}\text { Cadastro Técnico } \\
\text { Federal }\end{array}$ & $27 / 11 / 2013$ & $\mathrm{R} \$ 900,00$ & IPOJUCA & 2013 \\
\hline 02019.001309/2013-76 & 743732 & D & $\begin{array}{l}\text { Cadastro Técnico } \\
\text { Federal }\end{array}$ & $28 / 11 / 2013$ & $\mathrm{R} \$ 900,00$ & $\begin{array}{l}\text { SAO JOSE DA } \\
\text { COROA GRANDE }\end{array}$ & 2013 \\
\hline 02019.001359/2013-53 & 743848 & D & Flora & $02 / 12 / 2013$ & $\mathrm{R} \$ 16.000,00$ & PETROLINA & 2013 \\
\hline 02019.001365/2013-19 & 743969 & D & Flora & $03 / 12 / 2013$ & $\mathrm{R} \$ 16.200,00$ & EXU & 2013 \\
\hline 02019.001303/2013-07 & 743335 & D & Flora & $04 / 12 / 2013$ & $\mathrm{R} \$ 176.000,00$ & TRACUNHAEM & 2013 \\
\hline $02019.001302 / 2013-54$ & 743334 & D & Flora & $04 / 12 / 2013$ & $\mathrm{R} \$ 110.000,00$ & TRACUNHAEM & 2013 \\
\hline $02019.001364 / 2013-66$ & 743968 & D & Flora & $04 / 12 / 2013$ & $\mathrm{R} \$ 16.000,00$ & EXU & 2013 \\
\hline 02019.001310/2013-09 & 743730 & D & $\begin{array}{l}\text { Cadastro Técnico } \\
\text { Federal }\end{array}$ & $05 / 12 / 2013$ & $\mathrm{R} \$ 900,00$ & ILHA DE ITAMARACA & 2013 \\
\hline $02019.001311 / 2013-45$ & 743922 & $\mathrm{D}$ & Fauna & $09 / 12 / 2013$ & $\mathrm{R} \$ 1.000,00$ & ABREU E LIMA & 2013 \\
\hline 02019.001308/2013-21 & 743921 & D & Fauna & 09/12/2013 & $\mathrm{R} \$ 500,00$ & ABREU E LIMA & 2013 \\
\hline 02019.000316/2014-31 & 743534 & $\mathrm{D}$ & Flora & $09 / 12 / 2013$ & $\mathrm{R} \$ 30.900,00$ & PALMARES & 2013 \\
\hline 02019.001367/2013-08 & 743971 & D & Flora & 09/12/2013 & $\mathrm{R} \$ 8.000,00$ & SERRITA & 2013 \\
\hline $02019.001366 / 2013-55$ & 743970 & $\mathrm{D}$ & Flora & $09 / 12 / 2013$ & $\mathrm{R} \$ 6.381,00$ & SALGUEIRO & 2013 \\
\hline 02019.001368/2013-44 & 743972 & D & Flora & $09 / 12 / 2013$ & $\mathrm{R} \$ 2.000,00$ & SERRITA & 2013 \\
\hline 02019.001360/2013-88 & 743849 & D & Fauna & $10 / 12 / 2013$ & $\mathrm{R} \$ 19.000,00$ & FLORES & 2013 \\
\hline 02019.001361/2013-22 & 743850 & D & Fauna & $10 / 12 / 2013$ & $\mathrm{R} \$ 5.000,00$ & FLORES & 2013 \\
\hline 02019.001335/2013-02 & 743688 & D & Fauna & $12 / 12 / 2013$ & $\mathrm{R} \$ 1.500,00$ & BELO JARDIM & 2013 \\
\hline 02019.001351/2013-97 & 743363 & D & Flora & $12 / 12 / 2013$ & $\mathrm{R} \$ 24.750,00$ & CATENDE & 2013 \\
\hline 02019.000011/2014-20 & 743851 & D & Flora & $12 / 12 / 2013$ & $\mathrm{R} \$ 6.900,00$ & OURICURI & 2013 \\
\hline 02019.001326/2013-11 & 696349 & D & Controle ambiental & $13 / 12 / 2013$ & $\mathrm{R} \$ 2.000,00$ & BELO JARDIM & 2013 \\
\hline 02019.001348/2013-73 & 696113 & $\mathrm{D}$ & Controle ambiental & $13 / 12 / 2013$ & $\mathrm{R} \$ 2.000,00$ & BELO JARDIM & 2013 \\
\hline 02019.001336/2013-49 & 743689 & D & Controle ambiental & $13 / 12 / 2013$ & $\mathrm{R} \$ 2.000,00$ & BELO JARDIM & 2013 \\
\hline 02019.001349/2013-18 & 696114 & D & Controle ambiental & $13 / 12 / 2013$ & $\mathrm{R} \$ 2.000,00$ & BELO JARDIM & 2013 \\
\hline 02019.001325/2013-69 & 696350 & D & Controle ambiental & $13 / 12 / 2013$ & $\mathrm{R} \$ 2.000,00$ & BELO JARDIM & 2013 \\
\hline 02019.001337/2013-93 & 743690 & D & Pesca & $14 / 12 / 2013$ & $\mathrm{R} \$ 2.000,00$ & GRAVATA & 2013 \\
\hline 02019.001369/2013-99 & 743336 & D & Fauna & $16 / 12 / 2013$ & $\mathrm{R} \$ 4.500,00$ & VERDEJANTE & 2013 \\
\hline 02019.000018/2014-41 & 696675 & D & Fauna & $16 / 12 / 2013$ & $\mathrm{R} \$ 4.000,00$ & VERDEJANTE & 2013 \\
\hline 02019.001371/2013-68 & 743338 & D & Flora & $17 / 12 / 2013$ & $\mathrm{R} \$ 16.500,00$ & SERRITA & 2013 \\
\hline
\end{tabular}




\begin{tabular}{|c|c|c|c|c|c|c|c|}
\hline 02019.000078/2014-64 & 743852 & $\mathrm{D}$ & Flora & $17 / 12 / 2013$ & $\mathrm{R} \$ 6.000,00$ & BODOCO & 2013 \\
\hline 02019.000079/2014-17 & 743973 & D & Flora & $17 / 12 / 2013$ & $\mathrm{R} \$ 4.500,00$ & BODOCO & 2013 \\
\hline 02019.001370/2013-13 & 743337 & $\mathrm{D}$ & Flora & $18 / 12 / 2013$ & $\mathrm{R} \$ 3.000,00$ & BODOCO & 2013 \\
\hline 02019.000019/2014-96 & 696676 & D & Flora & $19 / 12 / 2013$ & $\mathrm{R} \$ 5.400,00$ & IPUBI & 2013 \\
\hline 02019.000020/2014-11 & 696677 & $\mathrm{D}$ & Fauna & $23 / 12 / 2013$ & $\mathrm{R} \$ 29.500,00$ & SALGUEIRO & 2013 \\
\hline 02019.000075/2014-21 & 696261 & D & Controle ambiental & $26 / 12 / 2013$ & $\mathrm{R} \$ 10.000,00$ & AGRESTINA & 2013 \\
\hline 02019.000015/2014-16 & 696116 & $\mathrm{D}$ & Controle ambiental & $26 / 12 / 2013$ & $\mathrm{R} \$ 10.000,00$ & CATENDE & 2013 \\
\hline 02019.000076/2014-75 & 696262 & D & Controle ambiental & 26/12/2013 & $\mathrm{R} \$ 10.000,00$ & CATENDE & 2013 \\
\hline 02019.000001/2014-94 & 695305 & $\mathrm{D}$ & Controle ambiental & $26 / 12 / 2013$ & $\mathrm{R} \$ 10.000,00$ & CATENDE & 2013 \\
\hline 02019.000080/2014-33 & 743974 & D & Flora & 26/12/2013 & $\mathrm{R} \$ 4.500,00$ & SERRITA & 2013 \\
\hline 02019.000016/2014-52 & 696117 & $\mathrm{D}$ & Controle ambiental & $27 / 12 / 2013$ & $\mathrm{R} \$ 10.000,00$ & CATENDE & 2013 \\
\hline 02019.000002/2014-39 & 695306 & $\mathrm{D}$ & Controle ambiental & 27/12/2013 & $\mathrm{R} \$ 10.000,00$ & CATENDE & 2013 \\
\hline 02019.000017/2014-05 & 696118 & $\mathrm{D}$ & Controle ambiental & $27 / 12 / 2013$ & $\mathrm{R} \$ 10.000,00$ & CATENDE & 2013 \\
\hline 02019.000077/2014-10 & 696263 & D & Controle ambiental & $27 / 12 / 2013$ & $\mathrm{R} \$ 10.000,00$ & CATENDE & 2013 \\
\hline 02019.000081/2014-88 & 743976 & $\mathrm{D}$ & Flora & $27 / 12 / 2013$ & $\mathrm{R} \$ 3.000,00$ & BODOCO & 2013 \\
\hline 02019.000144/2014-04 & 5778 & $E$ & Fauna & 08/01/2014 & $\mathrm{R} \$ 57.500,00$ & RECIFE & 2014 \\
\hline 02019.000195/2014-28 & 743854 & $\mathrm{D}$ & Fauna & $13 / 01 / 2014$ & $\mathrm{R} \$ 3.000,00$ & PARNAMIRIM & 2014 \\
\hline 02019.000194/2014-83 & 743925 & $\mathrm{D}$ & Fauna & 23/01/2014 & $\mathrm{R} \$ 5.000,00$ & OLINDA & 2014 \\
\hline 02019.000269/2014-26 & 9051617 & $E$ & Flora & $30 / 01 / 2014$ & $\mathrm{R} \$ 75.000,00$ & MARAIAL & 2014 \\
\hline 02019.000283/2014-20 & 9051313 & $E$ & Pesca & $01 / 02 / 2014$ & $\mathrm{R} \$ 1.780,00$ & IGARASSU & 2014 \\
\hline 02019.000375/2014-18 & 9074094 & $E$ & Flora & 05/02/2014 & $\mathrm{R} \$ 100.000,00$ & EXU & 2014 \\
\hline 02019.000348/2014-37 & 8890 & $E$ & Flora & 06/02/2014 & $\mathrm{R} \$ 22.000,00$ & EXU & 2014 \\
\hline 02019.000310/2014-64 & 8891 & $E$ & Flora & 06/02/2014 & $\mathrm{R} \$ 19.000,00$ & EXU & 2014 \\
\hline 02019.000284/2014-74 & 9051517 & $E$ & Fauna & $11 / 02 / 2014$ & $\mathrm{R} \$ 11.500,00$ & CAMARAGIBE & 2014 \\
\hline 02019.000312/2014-53 & 8893 & $E$ & Fauna & $11 / 02 / 2014$ & $\mathrm{R} \$ 5.000,00$ & $\begin{array}{l}\text { JABOATAO DOS } \\
\text { GUARARAPES }\end{array}$ & 2014 \\
\hline 02019.000313/2014-06 & 8894 & $E$ & Fauna & $11 / 02 / 2014$ & $\mathrm{R} \$ 2.500,00$ & SIRINHAEM & 2014 \\
\hline 02019.000319/2014-75 & 7165 & $E$ & Fauna & $11 / 02 / 2014$ & $\mathrm{R} \$ 1.500,00$ & RECIFE & 2014 \\
\hline 02019.000346/2014-48 & 9049775 & $E$ & Fauna & $11 / 02 / 2014$ & $\mathrm{R} \$ 1.000,00$ & RECIFE & 2014 \\
\hline 02019.000282/2014-85 & 9051312 & $E$ & $\begin{array}{l}\text { Org. Gen. Modific. e } \\
\text { Biopirataria }\end{array}$ & $11 / 02 / 2014$ & $\mathrm{R} \$ 40.000,00$ & RIACHO DAS ALMAS & 2014 \\
\hline 02019.000285/2014-19 & 9051519 & $E$ & Fauna & $12 / 02 / 2014$ & $\mathrm{R} \$ 51.000,00$ & RECIFE & 2014 \\
\hline 02019.000395/2014-81 & 9051318 & $E$ & Fauna & $12 / 02 / 2014$ & $\mathrm{R} \$ 24.000,00$ & CARPINA & 2014 \\
\hline 02019.000359/2014-17 & 9051522 & $E$ & Fauna & $12 / 02 / 2014$ & $\mathrm{R} \$ 15.500,00$ & AGRESTINA & 2014 \\
\hline 02019.000315/2014-97 & 9051525 & $E$ & Fauna & $12 / 02 / 2014$ & $\mathrm{R} \$ 13.000,00$ & FEIRA NOVA & 2014 \\
\hline 02019.000286/2014-63 & 9051518 & $E$ & Fauna & $12 / 02 / 2014$ & $\mathrm{R} \$ 6.500,00$ & $\begin{array}{l}\text { JABOATAO DOS } \\
\text { GUARARAPES }\end{array}$ & 2014 \\
\hline 02019.000345/2014-01 & 9049776 & $E$ & Fauna & $12 / 02 / 2014$ & $\mathrm{R} \$ 5.500,00$ & QUIPAPA & 2014 \\
\hline 02019.000320/2014-08 & 7166 & $E$ & Fauna & $12 / 02 / 2014$ & $\mathrm{R} \$ 2.000,00$ & RECIFE & 2014 \\
\hline 02019.000318/2014-21 & 7167 & $E$ & Fauna & $12 / 02 / 2014$ & $\mathrm{R} \$ 2.000,00$ & RECIFE & 2014 \\
\hline 02019.000391/2014-01 & 9051314 & $E$ & Fauna & $12 / 02 / 2014$ & $\mathrm{R} \$ 1.500,00$ & PAULISTA & 2014 \\
\hline 02019.000321/2014-44 & 9051520 & $E$ & Fauna & $12 / 02 / 2014$ & $\mathrm{R} \$ 1.500,00$ & SIRINHAEM & 2014 \\
\hline 02019.000392/2014-47 & 9051315 & $E$ & Fauna & $12 / 02 / 2014$ & $\mathrm{R} \$ 1.500,00$ & PAULISTA & 2014 \\
\hline 02019.000393/2014-91 & 9051316 & $E$ & Fauna & $12 / 02 / 2014$ & $\mathrm{R} \$ 500,00$ & ABREU E LIMA & 2014 \\
\hline 02019.000376/2014-54 & 9074093 & $E$ & Flora & $12 / 02 / 2014$ & $\mathrm{R} \$ 3.900,00$ & OURICURI & 2014 \\
\hline $02019.000350 / 2014-14$ & 9051559 & $E$ & Fauna & $13 / 02 / 2014$ & $\mathrm{R} \$ 328.000,00$ & RECIFE & 2014 \\
\hline 02019.000317/2014-86 & 9051527 & $E$ & Fauna & $13 / 02 / 2014$ & $\mathrm{R} \$ 13.000,00$ & FEIRA NOVA & 2014 \\
\hline 02019.000351/2014-51 & 9051598 & $E$ & Fauna & $13 / 02 / 2014$ & $\mathrm{R} \$ 4.000,00$ & TRACUNHAEM & 2014 \\
\hline 02019.000349/2014-81 & 9051521 & $E$ & Fauna & $13 / 02 / 2014$ & $\mathrm{R} \$ 1.500,00$ & OLINDA & 2014 \\
\hline 02019.000309/2014-30 & 9051320 & $E$ & Fauna & $14 / 02 / 2014$ & $\mathrm{R} \$ 25.000,00$ & TAMANDARE & 2014 \\
\hline 02019.000311/2014-17 & 8898 & $E$ & Fauna & $14 / 02 / 2014$ & $\mathrm{R} \$-$ & CARUARU & 2014 \\
\hline $02019.000383 / 2014-56$ & 9074090 & $E$ & Fauna & $19 / 02 / 2014$ & $\mathrm{R} \$ 20.000,00$ & CABROBO & 2014 \\
\hline 02019.000385/2014-45 & 9074095 & $E$ & Flora & $20 / 02 / 2014$ & $\mathrm{R} \$ 8.000,00$ & TERRA NOVA & 2014 \\
\hline 02019.000368/2014-16 & 9051614 & $E$ & Pesca & $20 / 02 / 2014$ & $\mathrm{R} \$ 5.120,00$ & GOIANA & 2014 \\
\hline 02019.000384/2014-09 & 9074091 & $E$ & Pesca & $24 / 02 / 2014$ & $\mathrm{R} \$ 30.700,00$ & FLORESTA & 2014 \\
\hline 02019.000387/2014-34 & 9074097 & $E$ & Flora & $25 / 02 / 2014$ & $\mathrm{R} \$ 900,00$ & ARARIPINA & 2014 \\
\hline 02019.000388/2014-89 & 9074096 & $E$ & Fauna & 08/03/2014 & $\mathrm{R} \$ 3.500,00$ & SALGUEIRO & 2014 \\
\hline 02019.000382/2014-10 & 9074098 & $E$ & Fauna & 08/03/2014 & $\mathrm{R} \$ 3.000,00$ & SALGUEIRO & 2014 \\
\hline 02019.000377/2014-07 & 743924 & $\mathrm{D}$ & Fauna & $11 / 03 / 2014$ & $\mathrm{R} \$ 81.000,00$ & GOIANA & 2014 \\
\hline
\end{tabular}




\begin{tabular}{|c|c|c|c|c|c|c|c|}
\hline $02019.000389 / 2014-23$ & 9049402 & $E$ & Fauna & $14 / 03 / 2014$ & $\mathrm{R} \$ 9.000,00$ & RECIFE & 2014 \\
\hline 02019.000471/2014-58 & 9074092 & $E$ & Fauna & $14 / 03 / 2014$ & $\mathrm{R} \$ 5.000,00$ & SERRITA & 2014 \\
\hline $02019.000432 / 2014-51$ & 9049778 & $E$ & Fauna & $14 / 03 / 2014$ & $\mathrm{R} \$ 3.000,00$ & SERRITA & 2014 \\
\hline 02019.000451/2014-87 & 9074099 & $E$ & Flora & $17 / 03 / 2014$ & $\mathrm{R} \$ 2.829,00$ & OURICURI & 2014 \\
\hline 02019.000411/2014-35 & 9049675 & $E$ & $\begin{array}{l}\text { Cadastro Técnico } \\
\text { Federal }\end{array}$ & $19 / 03 / 2014$ & $\mathrm{R} \$ 1.800,00$ & IPOJUCA & 2014 \\
\hline 02019.000438/2014-28 & 9049676 & $\mathrm{E}$ & Flora & $20 / 03 / 2014$ & $\mathrm{R} \$ 50.000,00$ & $\begin{array}{l}\text { CABO DE SANTO } \\
\text { AGOSTINHO }\end{array}$ & 2014 \\
\hline $02019.000431 / 2014-14$ & 9330 & $E$ & Pesca & $21 / 03 / 2014$ & $\mathrm{R} \$ 11.120,00$ & IGARASSU & 2014 \\
\hline 02019.000410/2014-91 & 9051319 & $E$ & Flora & $24 / 03 / 2014$ & $\mathrm{R} \$ 2.400,00$ & GAMELEIRA & 2014 \\
\hline 02019.000424/2014-12 & 9047726 & $E$ & Fauna & $25 / 03 / 2014$ & $\mathrm{R} \$ 6.000,00$ & RECIFE & 2014 \\
\hline 02019.000425/2014-59 & 9047727 & $E$ & Fauna & $25 / 03 / 2014$ & $\mathrm{R} \$ 5.000,00$ & RECIFE & 2014 \\
\hline $02019.000423 / 2014-60$ & 9047728 & $E$ & Fauna & $25 / 03 / 2014$ & $\mathrm{R} \$ 1.000,00$ & RECIFE & 2014 \\
\hline 02019.000426/2014-01 & 9051322 & $E$ & Fauna & $27 / 03 / 2014$ & $\mathrm{R} \$ 14.000,00$ & PAULISTA & 2014 \\
\hline 02019.000430/2014-61 & 9051324 & $E$ & Fauna & $27 / 03 / 2014$ & $\mathrm{R} \$ 6.500,00$ & $\begin{array}{l}\text { JABOATAO DOS } \\
\text { GUARARAPES }\end{array}$ & 2014 \\
\hline 02019.000435/2014-94 & 9051323 & $E$ & Fauna & $27 / 03 / 2014$ & $\mathrm{R} \$ 2.000,00$ & ABREU E LIMA & 2014 \\
\hline 02019.000427/2014-48 & 9051321 & $E$ & Fauna & $27 / 03 / 2014$ & $\mathrm{R} \$ 500,00$ & SIRINHAEM & 2014 \\
\hline $02019.000452 / 2014-21$ & 9074100 & $E$ & Fauna & $01 / 04 / 2014$ & $\mathrm{R} \$ 26.000,00$ & ITAPETIM & 2014 \\
\hline 02020.000064/2014-10 & 243 & $E$ & $\begin{array}{l}\text { Org. Gen. Modific. e } \\
\text { Biopirataria }\end{array}$ & $01 / 04 / 2014$ & $\mathrm{R} \$ 500,00$ & ARARIPINA & 2014 \\
\hline 02019.000437/2014-83 & 9051325 & $E$ & Flora & $02 / 04 / 2014$ & $R \$ 10.000,00$ & TRINDADE & 2014 \\
\hline 02019.000498/2014-41 & 9074101 & $E$ & Fauna & $09 / 04 / 2014$ & $\mathrm{R} \$ 15.000,00$ & SALGUEIRO & 2014 \\
\hline 02019.000507/2014-01 & 9074102 & $E$ & Fauna & $10 / 04 / 2014$ & $\mathrm{R} \$ 71.000,00$ & PETROLANDIA & 2014 \\
\hline 02019.000497/2014-04 & 9074103 & $E$ & Fauna & $10 / 04 / 2014$ & $\mathrm{R} \$ 19.000,00$ & PETROLANDIA & 2014 \\
\hline 02019.000468/2014-34 & 8889 & $E$ & Fauna & $10 / 04 / 2014$ & $\mathrm{R} \$ 5.500,00$ & RECIFE & 2014 \\
\hline 02019.000469/2014-89 & 8896 & $E$ & Fauna & $10 / 04 / 2014$ & $\mathrm{R} \$ 5.000,00$ & RECIFE & 2014 \\
\hline 02019.000470/2014-11 & 8897 & $E$ & Fauna & $10 / 04 / 2014$ & $\mathrm{R} \$ 5.000,00$ & RECIFE & 2014 \\
\hline $02019.000508 / 2014-48$ & 9074104 & $E$ & Fauna & $16 / 04 / 2014$ & $\mathrm{R} \$ 1.000,00$ & PETROLANDIA & 2014 \\
\hline 02019.000540/2014-23 & 9049677 & $E$ & $\begin{array}{l}\text { Org. Gen. Modific. e } \\
\text { Biopirataria }\end{array}$ & $23 / 04 / 2014$ & $R \$ 50.000,00$ & GLORIA DO GOITA & 2014 \\
\hline 02019.000510/2014-17 & 743691 & $\mathrm{D}$ & Fauna & $24 / 04 / 2014$ & $\mathrm{R} \$ 14.000,00$ & IATI & 2014 \\
\hline 02003.000433/2014-74 & 9061242 & $E$ & Pesca & $24 / 04 / 2014$ & $\mathrm{R} \$ 200.000,00$ & $\begin{array}{l}\text { SAO JOSE DA } \\
\text { COROA GRANDE }\end{array}$ & 2014 \\
\hline 02003.000434/2014-19 & 9061246 & $E$ & Pesca & $24 / 04 / 2014$ & $\mathrm{R} \$ 2.000,00$ & $\begin{array}{l}\text { SAO JOSE DA } \\
\text { COROA GRANDE }\end{array}$ & 2014 \\
\hline 02003.000440/2014-76 & 9061248 & $E$ & Pesca & $24 / 04 / 2014$ & $\mathrm{R} \$ 2.000,00$ & $\begin{array}{l}\text { SAO JOSE DA } \\
\text { COROA GRANDE }\end{array}$ & 2014 \\
\hline 02003.000321/2014-13 & 2833 & $E$ & Pesca & $26 / 04 / 2014$ & $\mathrm{R} \$ 2.500,00$ & TAMANDARE & 2014 \\
\hline 02003.000319/2014-44 & 2835 & $E$ & Pesca & $26 / 04 / 2014$ & $\mathrm{R} \$ 2.500,00$ & TAMANDARE & 2014 \\
\hline 02003.000322/2014-68 & 2836 & $E$ & Pesca & $26 / 04 / 2014$ & $\mathrm{R} \$ 2.500,00$ & TAMANDARE & 2014 \\
\hline 02003.000318/2014-08 & 2837 & $E$ & Pesca & $26 / 04 / 2014$ & $\mathrm{R} \$ 2.500,00$ & TAMANDARE & 2014 \\
\hline 02003.000323/2014-11 & 2838 & $E$ & Pesca & $26 / 04 / 2014$ & $\mathrm{R} \$ 2.500,00$ & TAMANDARE & 2014 \\
\hline 02003.000371/2014-09 & 2844 & $E$ & Pesca & $26 / 04 / 2014$ & $\mathrm{R} \$ 2.500,00$ & TAMANDARE & 2014 \\
\hline 02003.000372/2014-45 & 2846 & $E$ & Pesca & $26 / 04 / 2014$ & $\mathrm{R} \$ 2.500,00$ & TAMANDARE & 2014 \\
\hline 02003.000368/2014-87 & 2847 & $E$ & Pesca & $26 / 04 / 2014$ & $\mathrm{R} \$ 2.500,00$ & TAMANDARE & 2014 \\
\hline 02003.000373/2014-90 & 2853 & $E$ & Pesca & $27 / 04 / 2014$ & $\mathrm{R} \$ 2.500,00$ & TAMANDARE & 2014 \\
\hline 02019.000521/2014-05 & 7065 & $E$ & Fauna & $02 / 05 / 2014$ & $\mathrm{R} \$ 10.500,00$ & RECIFE & 2014 \\
\hline 02019.000520/2014-52 & 7068 & $E$ & Fauna & $02 / 05 / 2014$ & $\mathrm{R} \$ 5.000,00$ & RECIFE & 2014 \\
\hline 02019.000519/2014-28 & 7069 & $E$ & Fauna & $02 / 05 / 2014$ & $\mathrm{R} \$ 1.500,00$ & RECIFE & 2014 \\
\hline $02019.000625 / 2014-10$ & 9074105 & $E$ & Fauna & $13 / 05 / 2014$ & $\mathrm{R} \$ 9.000,00$ & INAJA & 2014 \\
\hline 02019.000544/2014-10 & 743308 & $\mathrm{D}$ & Controle ambiental & $14 / 05 / 2014$ & $\mathrm{R} \$ 30.000,00$ & IPUBI & 2014 \\
\hline $02577.000073 / 2014-14$ & 699101 & $\mathrm{D}$ & Pesca & $14 / 05 / 2014$ & $\mathrm{R} \$ 34.240,00$ & RECIFE & 2014 \\
\hline 02019.000558/2014-25 & 743651 & $\mathrm{D}$ & $\begin{array}{l}\text { Cadastro Técnico } \\
\text { Federal }\end{array}$ & $21 / 05 / 2014$ & $R \$ 5.000,00$ & SIRINHAEM & 2014 \\
\hline 02019.000549/2014-34 & 9051524 & $E$ & Flora & $21 / 05 / 2014$ & $\mathrm{R} \$ 8.000,00$ & ARCOVERDE & 2014 \\
\hline 02001.004025/2014-10 & 7193 & $E$ & $\begin{array}{l}\text { Org. Gen. Modific. e } \\
\text { Biopirataria }\end{array}$ & $21 / 05 / 2014$ & $\mathrm{R} \$ 200.500,00$ & SALGUEIRO & 2014 \\
\hline 02019.000626/2014-56 & 9074106 & $E$ & Fauna & $23 / 05 / 2014$ & $\mathrm{R} \$ 3.500,00$ & SERRITA & 2014 \\
\hline 02019.000627/2014-09 & 9074109 & $E$ & Fauna & 23/05/2014 & $\mathrm{R} \$ 2.000,00$ & SERRITA & 2014 \\
\hline
\end{tabular}




\begin{tabular}{|c|c|c|c|c|c|c|c|}
\hline 02001.004107/2014-56 & 7194 & $E$ & $\begin{array}{l}\text { Org. Gen. Modific. e } \\
\text { Biopirataria }\end{array}$ & $26 / 05 / 2014$ & $\mathrm{R} \$ 101.000,00$ & RECIFE & 2014 \\
\hline 02019.000563/2014-38 & 9049403 & $E$ & $\begin{array}{l}\text { Org. Gen. Modific. e } \\
\text { Biopirataria }\end{array}$ & $28 / 05 / 2014$ & $\mathrm{R} \$ 200.500,00$ & SERRITA & 2014 \\
\hline 02019.000577/2014-51 & 9049678 & $E$ & $\begin{array}{l}\text { Org. Gen. Modific. e } \\
\text { Biopirataria }\end{array}$ & $28 / 05 / 2014$ & $R \$ 100.500,00$ & SERRITA & 2014 \\
\hline 02019.000568/2014-61 & 9234 & $E$ & $\begin{array}{l}\text { Org. Gen. Modific. e } \\
\text { Biopirataria }\end{array}$ & 28/05/2014 & $\mathrm{R} \$ 10.500,00$ & SALGUEIRO & 2014 \\
\hline 02019.000652/2014-84 & 9074107 & $E$ & Fauna & $29 / 05 / 2014$ & $\mathrm{R} \$ 66.000,00$ & $\begin{array}{l}\text { SANTA MARIA DA } \\
\text { BOA VISTA }\end{array}$ & 2014 \\
\hline 02019.000641/2014-02 & 9074112 & $E$ & Fauna & $29 / 05 / 2014$ & $\mathrm{R} \$ 66.000,00$ & $\begin{array}{l}\text { SANTA MARIA DA } \\
\text { BOA VISTA }\end{array}$ & 2014 \\
\hline 02019.000642/2014-49 & 9074113 & $E$ & Fauna & $29 / 05 / 2014$ & $\mathrm{R} \$ 66.000,00$ & $\begin{array}{l}\text { SANTA MARIA DA } \\
\text { BOA VISTA }\end{array}$ & 2014 \\
\hline 02019.000643/2014-93 & 9074114 & $E$ & Fauna & 29/05/2014 & $\mathrm{R} \$ 66.000,00$ & $\begin{array}{l}\text { SANTA MARIA DA } \\
\text { BOA VISTA }\end{array}$ & 2014 \\
\hline 02019.000644/2014-38 & 9074115 & $E$ & Fauna & 29/05/2014 & $\mathrm{R} \$ 32.500,00$ & $\begin{array}{l}\text { SANTA MARIA DA } \\
\text { BOA VISTA }\end{array}$ & 2014 \\
\hline 02019.000650/2014-95 & 743856 & D & Fauna & 29/05/2014 & $\mathrm{R} \$ 32.500,00$ & $\begin{array}{l}\text { SANTA MARIA DA } \\
\text { BOA VISTA }\end{array}$ & 2014 \\
\hline 02019.000645/2014-82 & 9074116 & $E$ & Fauna & $29 / 05 / 2014$ & $\mathrm{R} \$ 32.500,00$ & $\begin{array}{l}\text { SANTA MARIA DA } \\
\text { BOA VISTA }\end{array}$ & 2014 \\
\hline 02019.000651/2014-30 & 743857 & D & Fauna & $29 / 05 / 2014$ & $\mathrm{R} \$ 32.500,00$ & $\begin{array}{l}\text { SANTA MARIA DA } \\
\text { BOA VISTA }\end{array}$ & 2014 \\
\hline 02019.000646/2014-27 & 9074117 & $E$ & Fauna & $29 / 05 / 2014$ & $\mathrm{R} \$ 32.500,00$ & $\begin{array}{l}\text { SANTA MARIA DA } \\
\text { BOA VISTA }\end{array}$ & 2014 \\
\hline 02019.000647/2014-71 & 9074119 & $E$ & Fauna & $29 / 05 / 2014$ & $\mathrm{R} \$ 32.500,00$ & $\begin{array}{l}\text { SANTA MARIA DA } \\
\text { BOA VISTA }\end{array}$ & 2014 \\
\hline 02019.000648/2014-16 & 9074120 & $E$ & Fauna & $29 / 05 / 2014$ & $\mathrm{R} \$ 32.500,00$ & $\begin{array}{l}\text { SANTA MARIA DA } \\
\text { BOA VISTA }\end{array}$ & 2014 \\
\hline 02019.000649/2014-61 & 9074122 & $E$ & Fauna & $29 / 05 / 2014$ & $\mathrm{R} \$ 32.500,00$ & $\begin{array}{l}\text { SANTA MARIA DA } \\
\text { BOA VISTA }\end{array}$ & 2014 \\
\hline 02019.000567/2014-16 & 9233 & $E$ & Controle ambiental & 03/06/2014 & $\mathrm{R} \$ 20.500,00$ & RECIFE & 2014 \\
\hline 02019.000580/2014-75 & 9235 & $E$ & Controle ambiental & 03/06/2014 & $\mathrm{R} \$ 20.500,00$ & SERRITA & 2014 \\
\hline 02019.000578/2014-04 & 9049679 & $E$ & $\begin{array}{l}\text { Org. Gen. Modific. e } \\
\text { Biopirataria }\end{array}$ & 03/06/2014 & $\mathrm{R} \$ 50.500,00$ & SERRITA & 2014 \\
\hline 02019.000575/2014-62 & 9236 & $E$ & $\begin{array}{l}\text { Org. Gen. Modific. e } \\
\text { Biopirataria }\end{array}$ & 03/06/2014 & $\mathrm{R} \$ 20.500,00$ & SERRITA & 2014 \\
\hline 02019.000576/2014-15 & 9049404 & $E$ & $\begin{array}{l}\text { Org. Gen. Modific. e } \\
\text { Biopirataria }\end{array}$ & 03/06/2014 & $\mathrm{R} \$ 20.000,00$ & SERRITA & 2014 \\
\hline 02019.000628/2014-45 & 9237 & $E$ & $\begin{array}{l}\text { Org. Gen. Modific. e } \\
\text { Biopirataria }\end{array}$ & 04/06/2014 & $\mathrm{R} \$ 500,00$ & SERTANIA & 2014 \\
\hline 02019.000608/2014-74 & 9049777 & $E$ & Flora & 09/06/2014 & $\mathrm{R} \$ 2.000,00$ & RECIFE & 2014 \\
\hline 02019.000622/2014-78 & 9049779 & $E$ & $\begin{array}{l}\text { Cadastro Técnico } \\
\text { Federal }\end{array}$ & $10 / 06 / 2014$ & $\mathrm{R} \$ 9.000,00$ & RECIFE & 2014 \\
\hline $02019.000621 / 2014-23$ & 7198 & $E$ & $\begin{array}{l}\text { Cadastro Técnico } \\
\text { Federal }\end{array}$ & $10 / 06 / 2014$ & $\mathrm{R} \$ 9.000,00$ & RECIFE & 2014 \\
\hline 02019.000619/2014-54 & 9238 & $E$ & $\begin{array}{l}\text { Cadastro Técnico } \\
\text { Federal }\end{array}$ & $11 / 06 / 2014$ & $\mathrm{R} \$ 9.000,00$ & RECIFE & 2014 \\
\hline 02019.000605/2014-31 & 9049780 & $E$ & $\begin{array}{l}\text { Cadastro Técnico } \\
\text { Federal }\end{array}$ & $11 / 06 / 2014$ & $\mathrm{R} \$ 9.000,00$ & RECIFE & 2014 \\
\hline 02019.000623/2014-12 & 9049781 & $\mathrm{E}$ & $\begin{array}{l}\text { Cadastro Técnico } \\
\text { Federal }\end{array}$ & $11 / 06 / 2014$ & $\mathrm{R} \$ 9.000,00$ & RECIFE & 2014 \\
\hline $02019.000624 / 2014-67$ & 9049782 & $\mathrm{E}$ & $\begin{array}{l}\text { Cadastro Técnico } \\
\text { Federal }\end{array}$ & $11 / 06 / 2014$ & $\mathrm{R} \$ 9.000,00$ & RECIFE & 2014 \\
\hline 02019.000604/2014-96 & 7169 & $E$ & $\begin{array}{l}\text { Cadastro Técnico } \\
\text { Federal }\end{array}$ & $11 / 06 / 2014$ & $\mathrm{R} \$ 9.000,00$ & RECIFE & 2014 \\
\hline 02019.000606/2014-85 & 9049783 & $E$ & $\begin{array}{l}\text { Cadastro Técnico } \\
\text { Federal }\end{array}$ & $11 / 06 / 2014$ & $\mathrm{R} \$ 9.000,00$ & RECIFE & 2014 \\
\hline 02019.000616/2014-11 & 9239 & $E$ & $\begin{array}{l}\text { Cadastro Técnico } \\
\text { Federal }\end{array}$ & $11 / 06 / 2014$ & $\mathrm{R} \$ 9.000,00$ & RECIFE & 2014 \\
\hline 02019.000613/2014-87 & 7204 & $E$ & $\begin{array}{l}\text { Cadastro Técnico } \\
\text { Federal }\end{array}$ & $11 / 06 / 2014$ & $\mathrm{R} \$ 9.000,00$ & RECIFE & 2014 \\
\hline 02019.000603/2014-41 & 7174 & $E$ & $\begin{array}{l}\text { Cadastro Técnico } \\
\text { Federal }\end{array}$ & $11 / 06 / 2014$ & $R \$ 9.000,00$ & RECIFE & 2014 \\
\hline 02019.000611/2014-98 & 7205 & $E$ & $\begin{array}{l}\text { Cadastro Técnico } \\
\text { Federal }\end{array}$ & $11 / 06 / 2014$ & $\mathrm{R} \$ 9.000,00$ & RECIFE & 2014 \\
\hline
\end{tabular}




\begin{tabular}{|c|c|c|c|c|c|c|c|}
\hline 02019.000601/2014-52 & 7175 & $E$ & $\begin{array}{l}\text { Cadastro Técnico } \\
\text { Federal }\end{array}$ & $11 / 06 / 2014$ & $\mathrm{R} \$ 9.000,00$ & RECIFE & 2014 \\
\hline 02019.000614/2014-21 & 7206 & $E$ & $\begin{array}{l}\text { Cadastro Técnico } \\
\text { Federal }\end{array}$ & $11 / 06 / 2014$ & $\mathrm{R} \$ 9.000,00$ & RECIFE & 2014 \\
\hline 02019.000620/2014-89 & 7176 & $E$ & $\begin{array}{l}\text { Cadastro Técnico } \\
\text { Federal }\end{array}$ & $11 / 06 / 2014$ & $\mathrm{R} \$ 9.000,00$ & RECIFE & 2014 \\
\hline 02019.000615/2014-76 & 9241 & $E$ & $\begin{array}{l}\text { Cadastro Técnico } \\
\text { Federal }\end{array}$ & $11 / 06 / 2014$ & $\mathrm{R} \$ 9.000,00$ & RECIFE & 2014 \\
\hline 02019.000602/2014-05 & 7177 & $E$ & $\begin{array}{l}\text { Cadastro Técnico } \\
\text { Federal }\end{array}$ & $11 / 06 / 2014$ & $R \$ 9.000,00$ & RECIFE & 2014 \\
\hline 02019.000618/2014-18 & 9242 & $E$ & $\begin{array}{l}\text { Cadastro Técnico } \\
\text { Federal }\end{array}$ & $11 / 06 / 2014$ & $\mathrm{R} \$ 9.000,00$ & RECIFE & 2014 \\
\hline 02019.000607/2014-20 & 9049784 & $E$ & $\begin{array}{l}\text { Cadastro Técnico } \\
\text { Federal }\end{array}$ & $11 / 06 / 2014$ & $\mathrm{R} \$ 9.000,00$ & RECIFE & 2014 \\
\hline 02019.000629/2014-90 & 9243 & $E$ & $\begin{array}{l}\text { Cadastro Técnico } \\
\text { Federal }\end{array}$ & $11 / 06 / 2014$ & $\mathrm{R} \$ 9.000,00$ & RECIFE & 2014 \\
\hline 02019.000630/2014-14 & 9244 & $E$ & $\begin{array}{l}\text { Cadastro Técnico } \\
\text { Federal }\end{array}$ & $11 / 06 / 2014$ & $\mathrm{R} \$ 9.000,00$ & RECIFE & 2014 \\
\hline 02019.000631/2014-69 & 9245 & $E$ & $\begin{array}{l}\text { Cadastro Técnico } \\
\text { Federal }\end{array}$ & $11 / 06 / 2014$ & $\mathrm{R} \$ 9.000,00$ & RECIFE & 2014 \\
\hline 02019.000632/2014-11 & 9246 & $E$ & $\begin{array}{l}\text { Cadastro Técnico } \\
\text { Federal }\end{array}$ & $11 / 06 / 2014$ & $\mathrm{R} \$ 9.000,00$ & RECIFE & 2014 \\
\hline 02019.000610/2014-43 & 7208 & $E$ & $\begin{array}{l}\text { Cadastro Técnico } \\
\text { Federal }\end{array}$ & $11 / 06 / 2014$ & $\mathrm{R} \$ 9.000,00$ & RECIFE & 2014 \\
\hline 02019.000609/2014-19 & 7209 & $\mathrm{E}$ & $\begin{array}{l}\text { Cadastro Técnico } \\
\text { Federal }\end{array}$ & $11 / 06 / 2014$ & $\mathrm{R} \$ 9.000,00$ & RECIFE & 2014 \\
\hline 02019.000617/2014-65 & 9240 & $E$ & $\begin{array}{l}\text { Cadastro Técnico } \\
\text { Federal }\end{array}$ & $11 / 06 / 2014$ & $\mathrm{R} \$ 1.800,00$ & RECIFE & 2014 \\
\hline 02019.000754/2014-08 & 8892 & $E$ & $\begin{array}{l}\text { Cadastro Técnico } \\
\text { Federal }\end{array}$ & $13 / 06 / 2014$ & $R \$ 9.000,00$ & RECIFE & 2014 \\
\hline 02019.000755/2014-44 & 8895 & $E$ & $\begin{array}{l}\text { Cadastro Técnico } \\
\text { Federal }\end{array}$ & $13 / 06 / 2014$ & $\mathrm{R} \$ 9.000,00$ & $\begin{array}{l}\text { JABOATAO DOS } \\
\text { GUARARAPES }\end{array}$ & 2014 \\
\hline 02019.000756/2014-99 & 8899 & $E$ & $\begin{array}{l}\text { Cadastro Técnico } \\
\text { Federal }\end{array}$ & $13 / 06 / 2014$ & $\mathrm{R} \$ 9.000,00$ & $\begin{array}{l}\text { JABOATAO DOS } \\
\text { GUARARAPES }\end{array}$ & 2014 \\
\hline 02019.000757/2014-33 & 8900 & $E$ & $\begin{array}{l}\text { Cadastro Técnico } \\
\text { Federal }\end{array}$ & $13 / 06 / 2014$ & $\mathrm{R} \$ 9.000,00$ & $\begin{array}{l}\text { JABOATAO DOS } \\
\text { GUARARAPES }\end{array}$ & 2014 \\
\hline 02019.000612/2014-32 & 7207 & $E$ & $\begin{array}{l}\text { Cadastro Técnico } \\
\text { Federal }\end{array}$ & $13 / 06 / 2014$ & $\mathrm{R} \$ 9.000,00$ & RECIFE & 2014 \\
\hline 02019.000639/2014-25 & 8892 & $E$ & $\begin{array}{l}\text { Cadastro Técnico } \\
\text { Federal }\end{array}$ & $13 / 06 / 2014$ & $\mathrm{R} \$ 5.000,00$ & RECIFE & 2014 \\
\hline 02019.000640/2014-50 & 8895 & $E$ & $\begin{array}{l}\text { Cadastro Técnico } \\
\text { Federal }\end{array}$ & $13 / 06 / 2014$ & $\mathrm{R} \$ 5.000,00$ & $\begin{array}{l}\text { JABOATAO DOS } \\
\text { GUARARAPES }\end{array}$ & 2014 \\
\hline 02019.000689/2014-11 & 9074108 & $E$ & Fauna & $18 / 06 / 2014$ & $\mathrm{R} \$ 3.000,00$ & PETROLINA & 2014 \\
\hline 02019.000688/2014-68 & 9074111 & $E$ & Fauna & $19 / 06 / 2014$ & $\mathrm{R} \$ 2.000,00$ & PETROLINA & 2014 \\
\hline 02019.000687/2014-13 & 9074110 & $E$ & Fauna & $19 / 06 / 2014$ & $\mathrm{R} \$ 1.500,00$ & PETROLINA & 2014 \\
\hline 02019.000684/2014-80 & 9074118 & $E$ & Fauna & $19 / 06 / 2014$ & $\mathrm{R} \$ 500,00$ & $\begin{array}{l}\text { SANTA MARIA DA } \\
\text { BOA VISTA }\end{array}$ & 2014 \\
\hline 02019.000686/2014-79 & 9074123 & $E$ & Fauna & $20 / 06 / 2014$ & $\mathrm{R} \$ 9.000,00$ & PETROLINA & 2014 \\
\hline 02019.000685/2014-24 & 9074121 & $E$ & Fauna & $20 / 06 / 2014$ & $\mathrm{R} \$ 1.000,00$ & PETROLINA & 2014 \\
\hline 02001.004755/2014-11 & 9056326 & $E$ & Flora & $20 / 06 / 2014$ & $\mathrm{R} \$ 56.500,00$ & SERRA TALHADA & 2014 \\
\hline 02019.000732/2014-30 & 9049785 & $E$ & Flora & 03/07/2014 & $\mathrm{R} \$ 6.600,00$ & PESQUEIRA & 2014 \\
\hline 02019.000773/2014-26 & 9049405 & $E$ & Fauna & $14 / 07 / 2014$ & $\begin{array}{l}\mathrm{R} \$ \\
1.410 .000,00\end{array}$ & OLINDA & 2014 \\
\hline 02019.000752/2014-19 & 9047729 & $E$ & Fauna & $14 / 07 / 2014$ & $\mathrm{R} \$ 420.000,00$ & OLINDA & 2014 \\
\hline 02019.000750/2014-11 & 9074 & $E$ & Fauna & $14 / 07 / 2014$ & $\mathrm{R} \$ 370.000,00$ & RECIFE & 2014 \\
\hline 02019.000748/2014-42 & 8899 & $E$ & Fauna & $14 / 07 / 2014$ & $\mathrm{R} \$ 200.000,00$ & OLINDA & 2014 \\
\hline 02019.000749/2014-97 & 8902 & $E$ & Fauna & $14 / 07 / 2014$ & $\mathrm{R} \$ 200.000,00$ & OLINDA & 2014 \\
\hline 02019.000774/2014-71 & 9049406 & $E$ & Fauna & $14 / 07 / 2014$ & $\mathrm{R} \$ 190.000,00$ & OLINDA & 2014 \\
\hline 02019.000747/2014-06 & 7168 & $E$ & Fauna & $14 / 07 / 2014$ & $\mathrm{R} \$ 100.000,00$ & OLINDA & 2014 \\
\hline 02019.000751/2014-66 & 9111 & $E$ & Flora & $19 / 07 / 2014$ & $\mathrm{R} \$ 3.900,00$ & $\begin{array}{l}\text { SAO JOSE DO } \\
\text { BELMONTE }\end{array}$ & 2014 \\
\hline 02019.000729/2014-16 & 9049680 & $E$ & Flora & $22 / 07 / 2014$ & $\mathrm{R} \$ 10.000,00$ & SERRA TALHADA & 2014 \\
\hline 02019.000728/2014-71 & 9049684 & $E$ & Fauna & $23 / 07 / 2014$ & $\mathrm{R} \$ 4.500,00$ & RECIFE & 2014 \\
\hline 02019.000730/2014-41 & 9049681 & $E$ & Fauna & $23 / 07 / 2014$ & $\mathrm{R} \$ 1.500,00$ & RECIFE & 2014 \\
\hline 02019.000731/2014-95 & 8900 & $E$ & Flora & $23 / 07 / 2014$ & $\mathrm{R} \$ 1.698,00$ & SERTANIA & 2014 \\
\hline
\end{tabular}




\begin{tabular}{|c|c|c|c|c|c|c|c|}
\hline 02019.000878/2014-85 & 9049405 & $\mathrm{E}$ & Fauna & 06/08/2014 & $\mathrm{R} \$ 11.000,00$ & $\begin{array}{l}\text { TAQUARITINGA DO } \\
\text { NORTE }\end{array}$ & 2014 \\
\hline 02019.001091/2014-31 & 9049406 & $\mathrm{E}$ & Controle ambiental & $07 / 08 / 2014$ & $\mathrm{R} \$ 1.500,00$ & JATAUBA & 2014 \\
\hline 02019.000799/2014-74 & 9051618 & $\mathrm{E}$ & Fauna & $07 / 08 / 2014$ & $\mathrm{R} \$ 5.000,00$ & OLINDA & 2014 \\
\hline 02019.000788/2014-94 & 7170 & $\mathrm{E}$ & Flora & $07 / 08 / 2014$ & $\mathrm{R} \$ 5.000,00$ & RECIFE & 2014 \\
\hline 02019.000800/2014-61 & 9051620 & $\mathrm{E}$ & Fauna & $08 / 08 / 2014$ & $\mathrm{R} \$ 19.000,00$ & OLINDA & 2014 \\
\hline 02019.000803/2014-02 & 9051619 & $E$ & Fauna & 08/08/2014 & $\mathrm{R} \$ 900,00$ & OLINDA & 2014 \\
\hline 02019.000875/2014-41 & 9049408 & $\mathrm{E}$ & Flora & $11 / 08 / 2014$ & $\mathrm{R} \$ 69.000,00$ & $\begin{array}{l}\text { SANTA CRUZ DO } \\
\text { CAPIBARIBE }\end{array}$ & 2014 \\
\hline 02019.000874/2014-05 & 7171 & $\mathrm{E}$ & Flora & $12 / 08 / 2014$ & $\mathrm{R} \$ 16.000,00$ & $\begin{array}{l}\text { SANTA CRUZ DO } \\
\text { CAPIBARIBE }\end{array}$ & 2014 \\
\hline 02019.000876/2014-96 & 9049410 & $\mathrm{E}$ & Flora & $13 / 08 / 2014$ & $\mathrm{R} \$ 5.500,00$ & BONITO & 2014 \\
\hline 02019.000881/2014-07 & 9074124 & $E$ & Fauna & $20 / 08 / 2014$ & $\mathrm{R} \$ 12.000,00$ & SALGUEIRO & 2014 \\
\hline 02019.000908/2014-53 & 9074125 & $\mathrm{E}$ & Flora & $25 / 08 / 2014$ & $\mathrm{R} \$ 100.000,00$ & PETROLINA & 2014 \\
\hline 02019.000910/2014-22 & 9074127 & $E$ & Flora & $28 / 08 / 2014$ & $\mathrm{R} \$ 2.250,00$ & SERRA TALHADA & 2014 \\
\hline 02019.000909/2014-06 & 9074126 & $\mathrm{E}$ & Flora & $28 / 08 / 2014$ & $\mathrm{R} \$ 1.140,00$ & SERRA TALHADA & 2014 \\
\hline 02019.000886/2014-21 & 9130 & $\mathrm{E}$ & Pesca & 03/09/2014 & $\mathrm{R} \$ 12.600,00$ & RECIFE & 2014 \\
\hline 02019.000959/2014-85 & 9049407 & $E$ & $\begin{array}{l}\text { Org. Gen. Modific. e } \\
\text { Biopirataria }\end{array}$ & 05/09/2014 & $\mathrm{R} \$ 2.000,00$ & TAMANDARE & 2014 \\
\hline 02019.000973/2014-89 & 9051621 & $E$ & $\begin{array}{l}\text { Cadastro Técnico } \\
\text { Federal }\end{array}$ & 08/09/2014 & $\mathrm{R} \$ 11.000,00$ & PALMARES & 2014 \\
\hline 02019.000960/2014-18 & 9049411 & $\mathrm{E}$ & Controle ambiental & 08/09/2014 & $\mathrm{R} \$ 2.500,00$ & JATAUBA & 2014 \\
\hline 02019.000951/2014-19 & 9049412 & $\mathrm{E}$ & Controle ambiental & 08/09/2014 & $\mathrm{R} \$ 2.500,00$ & JATAUBA & 2014 \\
\hline 02019.000961/2014-54 & 9049413 & $E$ & Controle ambiental & 08/09/2014 & $\mathrm{R} \$ 2.500,00$ & JATAUBA & 2014 \\
\hline 02019.000952/2014-63 & 9049414 & $\mathrm{E}$ & Controle ambiental & 08/09/2014 & $\mathrm{R} \$ 2.500,00$ & $\begin{array}{l}\text { SANTA CRUZ DO } \\
\text { CAPIBARIBE }\end{array}$ & 2014 \\
\hline 02019.001092/2014-85 & 9051529 & $E$ & $\begin{array}{l}\text { Cadastro Técnico } \\
\text { Federal }\end{array}$ & 09/09/2014 & $\mathrm{R} \$ 21.000,00$ & RECIFE & 2014 \\
\hline 02019.001093/2014-20 & 9051532 & $E$ & $\begin{array}{l}\text { Cadastro Técnico } \\
\text { Federal }\end{array}$ & 09/09/2014 & $\mathrm{R} \$ 21.000,00$ & RECIFE & 2014 \\
\hline 02019.000974/2014-23 & 9051622 & $E$ & Fauna & 09/09/2014 & $\begin{array}{l}\mathrm{R} \$ \\
1.470 .000,00\end{array}$ & OLINDA & 2014 \\
\hline 02019.000953/2014-16 & 9049415 & E & Pesca & 09/09/2014 & $\mathrm{R} \$ 1.700,00$ & $\begin{array}{l}\text { SAO JOSE DA } \\
\text { COROA GRANDE }\end{array}$ & 2014 \\
\hline 02019.000981/2014-25 & 9051533 & $E$ & $\begin{array}{l}\text { Cadastro Técnico } \\
\text { Federal }\end{array}$ & $10 / 09 / 2014$ & $\mathrm{R} \$ 21.000,00$ & CARPINA & 2014 \\
\hline 02019.000982/2014-70 & 9051535 & $\mathrm{E}$ & $\begin{array}{l}\text { Cadastro Técnico } \\
\text { Federal }\end{array}$ & $10 / 09 / 2014$ & $\mathrm{R} \$ 21.000,00$ & $\begin{array}{l}\text { JABOATAO DOS } \\
\text { GUARARAPES }\end{array}$ & 2014 \\
\hline 02019.001090/2014-96 & 7212 & $\mathrm{E}$ & $\begin{array}{l}\text { Org. Gen. Modific. e } \\
\text { Biopirataria }\end{array}$ & $15 / 09 / 2014$ & $\mathrm{R} \$ 500,00$ & ITAPISSUMA & 2014 \\
\hline 02019.001027/2014-50 & 9049409 & $\mathrm{E}$ & Fauna & $16 / 09 / 2014$ & $\mathrm{R} \$ 3.500,00$ & BELO JARDIM & 2014 \\
\hline 02019.000993/2014-50 & 7214 & $E$ & Controle ambiental & $17 / 09 / 2014$ & $\mathrm{R} \$ 50.000,00$ & TIMBAUBA & 2014 \\
\hline 02019.001042/2014-06 & 9049417 & $\mathrm{E}$ & Pesca & $17 / 09 / 2014$ & $\mathrm{R} \$ 1.260,00$ & GOIANA & 2014 \\
\hline 02019.000987/2014-01 & 9049418 & $E$ & Pesca & $23 / 09 / 2014$ & $\mathrm{R} \$ 1.300,00$ & GOIANA & 2014 \\
\hline 02019.001035/2014-04 & 9074128 & $\mathrm{E}$ & Fauna & $24 / 09 / 2014$ & $\mathrm{R} \$ 7.000,00$ & TRIUNFO & 2014 \\
\hline 02019.001341/2014-32 & 9074129 & $E$ & Flora & $24 / 09 / 2014$ & $\mathrm{R} \$ 24.000,00$ & SERRA TALHADA & 2014 \\
\hline 02019.001129/2014-75 & 9260 & $E$ & $\begin{array}{l}\text { Cadastro Técnico } \\
\text { Federal }\end{array}$ & 01/10/2014 & $\mathrm{R} \$ 1.500,00$ & PAUDALHO & 2014 \\
\hline 02019.001130/2014-08 & 9261 & $E$ & $\begin{array}{l}\text { Cadastro Técnico } \\
\text { Federal }\end{array}$ & $01 / 10 / 2014$ & $\mathrm{R} \$ 1.500,00$ & PAUDALHO & 2014 \\
\hline 02019.001127/2014-86 & 9257 & $\mathrm{E}$ & Controle ambiental & $01 / 10 / 2014$ & $\mathrm{R} \$ 20.000,00$ & PAUDALHO & 2014 \\
\hline 02019.001128/2014-21 & 9258 & $E$ & Controle ambiental & $01 / 10 / 2014$ & $\mathrm{R} \$ 20.000,00$ & PAUDALHO & 2014 \\
\hline 02019.001126/2014-31 & 9255 & $\mathrm{E}$ & $\begin{array}{l}\text { Org. Gen. Modific. e } \\
\text { Biopirataria }\end{array}$ & 01/10/2014 & $\mathrm{R} \$ 20.000,00$ & PAUDALHO & 2014 \\
\hline 02019.001132/2014-99 & 9263 & $E$ & $\begin{array}{l}\text { Cadastro Técnico } \\
\text { Federal }\end{array}$ & 03/10/2014 & $\mathrm{R} \$ 2.000,00$ & LAGOA DO ITAENGA & 2014 \\
\hline 02019.001131/2014-44 & 9262 & $E$ & $\begin{array}{l}\text { Org. Gen. Modific. e } \\
\text { Biopirataria }\end{array}$ & 03/10/2014 & $\mathrm{R} \$ 30.000,00$ & LAGOA DO ITAENGA & 2014 \\
\hline 02019.001342/2014-87 & 8905 & $E$ & $\begin{array}{l}\text { Cadastro Técnico } \\
\text { Federal }\end{array}$ & $10 / 10 / 2014$ & $\mathrm{R} \$ 5.000,00$ & PAULISTA & 2014 \\
\hline 02019.001343/2014-21 & 8906 & $E$ & $\begin{array}{l}\text { Org. Gen. Modific. e } \\
\text { Biopirataria }\end{array}$ & $10 / 10 / 2014$ & $\mathrm{R} \$ 3.000,00$ & PAULISTA & 2014 \\
\hline 02019.001193/2014-56 & 7172 & $\mathrm{E}$ & Flora & $12 / 10 / 2014$ & $\mathrm{R} \$ 3.000,00$ & CUSTODIA & 2014 \\
\hline 02019.001197/2014-34 & 7173 & $E$ & Flora & $13 / 10 / 2014$ & $\mathrm{R} \$ 5.000,00$ & PETROLINA & 2014 \\
\hline
\end{tabular}




\begin{tabular}{|c|c|c|c|c|c|c|c|}
\hline 02019.001179/2014-52 & 9256 & $E$ & $\begin{array}{l}\text { Cadastro Técnico } \\
\text { Federal }\end{array}$ & $14 / 10 / 2014$ & $\mathrm{R} \$ 5.000,00$ & GLORIA DO GOITA & 2014 \\
\hline 02019.001196/2014-90 & 7178 & $E$ & $\begin{array}{l}\text { Org. Gen. Modific. e } \\
\text { Biopirataria }\end{array}$ & $14 / 10 / 2014$ & $\mathrm{R} \$ 1.500,00$ & $\begin{array}{l}\text { SANTA MARIA DA } \\
\text { BOA VISTA }\end{array}$ & 2014 \\
\hline 02019.001182/2014-76 & 9264 & $E$ & Flora & $15 / 10 / 2014$ & $\mathrm{R} \$ 18.000,00$ & LIMOEIRO & 2014 \\
\hline 02019.001180/2014-87 & 9265 & $E$ & $\begin{array}{l}\text { Org. Gen. Modific. e } \\
\text { Biopirataria }\end{array}$ & $15 / 10 / 2014$ & $\mathrm{R} \$ 20.000,00$ & LIMOEIRO & 2014 \\
\hline 02019.001174/2014-20 & 9051625 & $\mathrm{E}$ & $\begin{array}{l}\text { Org. Gen. Modific. e } \\
\text { Biopirataria }\end{array}$ & $16 / 10 / 2014$ & $\mathrm{R} \$ 30.000,00$ & RECIFE & 2014 \\
\hline 02019.001181/2014-21 & 9266 & $E$ & $\begin{array}{l}\text { Org. Gen. Modific. e } \\
\text { Biopirataria }\end{array}$ & $16 / 10 / 2014$ & $R \$ 20.000,00$ & BEZERROS & 2014 \\
\hline 02019.001172/2014-31 & 8909 & $E$ & Fauna & $17 / 10 / 2014$ & $\mathrm{R} \$ 227.000,00$ & RECIFE & 2014 \\
\hline 02019.001178/2014-16 & 9267 & $\mathrm{E}$ & $\begin{array}{l}\text { Org. Gen. Modific. e } \\
\text { Biopirataria }\end{array}$ & $17 / 10 / 2014$ & $\mathrm{R} \$ 900,00$ & BOM JARDIM & 2014 \\
\hline 02019.001344/2014-76 & 9074130 & $E$ & Fauna & $18 / 10 / 2014$ & $\mathrm{R} \$ 11.000,00$ & PETROLANDIA & 2014 \\
\hline 02019.001184/2014-65 & 7179 & $E$ & Flora & 20/10/2014 & $\mathrm{R} \$ 10.000,00$ & $\begin{array}{l}\text { SAO JOSE DO } \\
\text { BELMONTE }\end{array}$ & 2014 \\
\hline 02019.001194/2014-09 & 9074131 & $E$ & $\begin{array}{l}\text { Org. Gen. Modific. e } \\
\text { Biopirataria }\end{array}$ & $22 / 10 / 2014$ & $\mathrm{R} \$ 3.000,00$ & BEZERROS & 2014 \\
\hline 02019.001195/2014-45 & 9074132 & $E$ & Controle ambiental & $24 / 10 / 2014$ & $\mathrm{R} \$ 10.000,00$ & JATAUBA & 2014 \\
\hline 02019.001205/2014-42 & 9074134 & $E$ & Flora & $25 / 10 / 2014$ & $\mathrm{R} \$ 4.500,00$ & TRINDADE & 2014 \\
\hline 02019.001201/2014-64 & 9051623 & $E$ & Pesca & $31 / 10 / 2014$ & $\mathrm{R} \$ 10.000,00$ & ITAPISSUMA & 2014 \\
\hline 02019.001236/2014-01 & 9074133 & $E$ & Fauna & $04 / 11 / 2014$ & $R \$ 500,00$ & SALGUEIRO & 2014 \\
\hline 02019.001355/2014-56 & 743161 & D & $\begin{array}{l}\text { Cadastro Técnico } \\
\text { Federal }\end{array}$ & $10 / 11 / 2014$ & $\mathrm{R} \$ 5.000,00$ & SERRA TALHADA & 2014 \\
\hline 02019.001354/2014-10 & 743162 & D & $\begin{array}{l}\text { Cadastro Técnico } \\
\text { Federal }\end{array}$ & $10 / 11 / 2014$ & $\mathrm{R} \$ 5.000,00$ & CARUARU & 2014 \\
\hline 02019.001252/2014-96 & 9049419 & $E$ & Controle ambiental & $10 / 11 / 2014$ & $\begin{array}{l}\mathrm{R} \$ \\
2.505 .000,00\end{array}$ & RECIFE & 2014 \\
\hline 02019.001352/2014-12 & 743164 & D & $\begin{array}{l}\text { Cadastro Técnico } \\
\text { Federal }\end{array}$ & $11 / 11 / 2014$ & $\mathrm{R} \$ 5.000,00$ & CARUARU & 2014 \\
\hline 02019.001351/2014-78 & 743165 & D & $\begin{array}{l}\text { Cadastro Técnico } \\
\text { Federal }\end{array}$ & $11 / 11 / 2014$ & $\mathrm{R} \$ 1.500,00$ & CARUARU & 2014 \\
\hline 02019.001350/2014-23 & 743167 & D & $\begin{array}{l}\text { Cadastro Técnico } \\
\text { Federal }\end{array}$ & $11 / 11 / 2014$ & $\mathrm{R} \$ 1.500,00$ & CARUARU & 2014 \\
\hline 02019.001349/2014-07 & 743168 & D & $\begin{array}{l}\text { Cadastro Técnico } \\
\text { Federal }\end{array}$ & $11 / 11 / 2014$ & $\mathrm{R} \$ 1.500,00$ & CARUARU & 2014 \\
\hline 02019.001353/2014-67 & 743163 & $\mathrm{D}$ & Controle ambiental & $11 / 11 / 2014$ & $R \$ 30.000,00$ & CARUARU & 2014 \\
\hline 02019.001348/2014-54 & 743169 & $\mathrm{D}$ & Controle ambiental & $11 / 11 / 2014$ & $R \$ 20.000,00$ & CARUARU & 2014 \\
\hline 02019.001347/2014-18 & 743170 & $\mathrm{D}$ & Controle ambiental & $12 / 11 / 2014$ & $R \$ 20.000,00$ & CARUARU & 2014 \\
\hline 02019.001346/2014-65 & 743172 & $\mathrm{D}$ & Controle ambiental & $13 / 11 / 2014$ & $\mathrm{R} \$ 20.000,00$ & SAO CAITANO & 2014 \\
\hline 02019.001476/2014-06 & 9074135 & $E$ & Flora & $14 / 11 / 2014$ & $R \$ 12.000,00$ & SALGUEIRO & 2014 \\
\hline 02019.001477/2014-42 & 743174 & $\mathrm{D}$ & Controle ambiental & $24 / 11 / 2014$ & $\mathrm{R} \$ 30.000,00$ & TACAIMBO & 2014 \\
\hline 02019.001467/2014-15 & 9051539 & $E$ & Controle ambiental & $24 / 11 / 2014$ & $\mathrm{R} \$ 7.500,00$ & RECIFE & 2014 \\
\hline 02019.001466/2014-62 & 9051544 & $E$ & Controle ambiental & $24 / 11 / 2014$ & $\mathrm{R} \$ 5.000,00$ & RECIFE & 2014 \\
\hline 02019.001464/2014-73 & 9051545 & $E$ & $\begin{array}{l}\text { Org. Gen. Modific. e } \\
\text { Biopirataria }\end{array}$ & $25 / 11 / 2014$ & $\mathrm{R} \$ 20.000,00$ & CUSTODIA & 2014 \\
\hline 02019.001465/2014-18 & 9051548 & $E$ & $\begin{array}{l}\text { Org. Gen. Modific. e } \\
\text { Biopirataria }\end{array}$ & $25 / 11 / 2014$ & $\mathrm{R} \$ 20.000,00$ & $\begin{array}{l}\text { SAO JOSE DO } \\
\text { BELMONTE }\end{array}$ & 2014 \\
\hline 02019.001492/2014-91 & 9049703 & $E$ & $\begin{array}{l}\text { Org. Gen. Modific. e } \\
\text { Biopirataria }\end{array}$ & $25 / 11 / 2014$ & $R \$ 5.000,00$ & IGARASSU & 2014 \\
\hline 02019.001493/2014-35 & 9049705 & $E$ & Flora & $02 / 12 / 2014$ & $\mathrm{R} \$ 900,00$ & IBIRAJUBA & 2014 \\
\hline 02019.001495/2014-24 & 9049707 & $E$ & Controle ambiental & $03 / 12 / 2014$ & $\mathrm{R} \$ 80.000,00$ & TACAIMBO & 2014 \\
\hline 02019.001494/2014-80 & 9049706 & $E$ & Controle ambiental & 03/12/2014 & $\mathrm{R} \$ 50.500,00$ & TACAIMBO & 2014 \\
\hline 02019.001475/2014-53 & 9074136 & $E$ & Flora & $03 / 12 / 2014$ & $\mathrm{R} \$ 8.000,00$ & EXU & 2014 \\
\hline 02019.001504/2014-87 & 9049416 & $E$ & Fauna & $04 / 12 / 2014$ & $\mathrm{R} \$ 5.000,00$ & RECIFE & 2014 \\
\hline 02019.001496/2014-79 & 9049708 & $E$ & Flora & $04 / 12 / 2014$ & $\mathrm{R} \$ 600,00$ & PESQUEIRA & 2014 \\
\hline 02019.001498/2014-68 & 9049710 & $E$ & Controle ambiental & 05/12/2014 & $\mathrm{R} \$ 6.000,00$ & BREJINHO & 2014 \\
\hline 02019.001497/2014-13 & 9049709 & $E$ & Controle ambiental & $05 / 12 / 2014$ & $\mathrm{R} \$ 3.000,00$ & BREJINHO & 2014 \\
\hline 02019.001479/2014-31 & 9051540 & $E$ & Flora & 05/12/2014 & $\mathrm{R} \$ 5.000,00$ & IPOJUCA & 2014 \\
\hline 02019.001478/2014-97 & 9051557 & $E$ & Flora & 05/12/2014 & $\mathrm{R} \$ 1.000,00$ & IPOJUCA & 2014 \\
\hline 02019.001499/2014-11 & 9049712 & $E$ & Controle ambiental & $08 / 12 / 2014$ & $\mathrm{R} \$ 3.000,00$ & BREJINHO & 2014 \\
\hline 02019.000051/2015-52 & 9074137 & $E$ & Fauna & $08 / 12 / 2014$ & $\mathrm{R} \$ 2.000,00$ & SALGUEIRO & 2014 \\
\hline
\end{tabular}




\begin{tabular}{|c|c|c|c|c|c|c|c|}
\hline 02019.001505/2014-21 & 743173 & D & Fauna & 09/12/2014 & $\mathrm{R} \$ 57.000,00$ & GARANHUNS & 2014 \\
\hline 02019.000077/2015-09 & 9074138 & $E$ & Flora & $09 / 12 / 2014$ & $\mathrm{R} \$ 3.600,00$ & PARNAMIRIM & 2014 \\
\hline 02019.000076/2015-56 & 9074140 & $E$ & Flora & 09/12/2014 & $\mathrm{R} \$ 3.000,00$ & PARNAMIRIM & 2014 \\
\hline 02019.001500/2014-07 & 9049713 & $E$ & Flora & $09 / 12 / 2014$ & $\mathrm{R} \$ 900,00$ & SOLIDAO & 2014 \\
\hline 02019.001501/2014-43 & 9049714 & $E$ & Flora & $10 / 12 / 2014$ & $\mathrm{R} \$ 6.300,00$ & $\begin{array}{l}\text { AFOGADOS DA } \\
\text { INGAZEIRA }\end{array}$ & 2014 \\
\hline 02019.000075/2015-10 & 9074141 & $E$ & Flora & $10 / 12 / 2014$ & $\mathrm{R} \$ 4.500,00$ & PARNAMIRIM & 2014 \\
\hline 02019.001502/2014-98 & 9049715 & $E$ & Flora & $10 / 12 / 2014$ & $\mathrm{R} \$ 1.200,00$ & ITAPETIM & 2014 \\
\hline 02019.001485/2014-99 & 9088777 & $E$ & Pesca & $10 / 12 / 2014$ & $\mathrm{R} \$ 2.500,00$ & IPOJUCA & 2014 \\
\hline 02019.001520/2014-70 & 743175 & D & $\begin{array}{l}\text { Cadastro Técnico } \\
\text { Federal }\end{array}$ & $14 / 12 / 2014$ & $\mathrm{R} \$ 5.000,00$ & LAJEDO & 2014 \\
\hline 02019.001516/2014-10 & 9049420 & $E$ & Fauna & $15 / 12 / 2014$ & $\mathrm{R} \$ 5.000,00$ & $\begin{array}{l}\text { SAO LOURENCO DA } \\
\text { MATA }\end{array}$ & 2014 \\
\hline 02019.000052/2015-05 & 9091662 & $E$ & Fauna & $17 / 12 / 2014$ & $\mathrm{R} \$ 2.500,00$ & LAGOA GRANDE & 2014 \\
\hline 02019.000078/2015-45 & 9074139 & $E$ & Fauna & $17 / 12 / 2014$ & $\mathrm{R} \$ 500,00$ & LAGOA GRANDE & 2014 \\
\hline 02019.001511/2014-89 & 7180 & $E$ & Flora & $17 / 12 / 2014$ & $\mathrm{R} \$ 1.000,00$ & RECIFE & 2014 \\
\hline 02019.001519/2014-45 & 9049716 & $E$ & $\begin{array}{l}\text { Cadastro Técnico } \\
\text { Federal }\end{array}$ & $22 / 12 / 2014$ & $\mathrm{R} \$ 9.000,00$ & RECIFE & 2014 \\
\hline 02019.001517/2014-56 & 9049421 & $E$ & $\begin{array}{l}\text { Org. Gen. Modific. e } \\
\text { Biopirataria }\end{array}$ & $22 / 12 / 2014$ & $R \$ 20.000,00$ & CARPINA & 2014 \\
\hline 02019.000015/2015-99 & 9049711 & $E$ & Pesca & $22 / 12 / 2014$ & $\mathrm{R} \$ 52.200,00$ & RECIFE & 2014 \\
\hline 02019.001521/2014-14 & 743176 & D & $\begin{array}{l}\text { Cadastro Técnico } \\
\text { Federal }\end{array}$ & 23/12/2014 & $R \$ 9.000,00$ & CARUARU & 2014 \\
\hline $02019.000014 / 2015-44$ & 9049424 & $E$ & Flora & $26 / 12 / 2014$ & $\mathrm{R} \$ 46.000,00$ & PASSIRA & 2014 \\
\hline 02019.000013/2015-08 & 9049423 & $E$ & Flora & $26 / 12 / 2014$ & $\mathrm{R} \$ 5.000,00$ & $\begin{array}{l}\text { TAQUARITINGA DO } \\
\text { NORTE }\end{array}$ & 2014 \\
\hline $02019.000148 / 2015-65$ & 9051554 & $E$ & Pesca & $22 / 01 / 2015$ & $\mathrm{R} \$ 2.040,00$ & PETROLINA & 2015 \\
\hline 02019.000198/2015-42 & 9092655 & $E$ & Pesca & $26 / 01 / 2015$ & $\mathrm{R} \$ 1.700,00$ & $\begin{array}{l}\text { BELEM DE SAO } \\
\text { FRANCISCO }\end{array}$ & 2015 \\
\hline 02019.000147/2015-11 & 9259 & $E$ & Flora & $27 / 01 / 2015$ & $\mathrm{R} \$ 100.000,00$ & ALTINHO & 2015 \\
\hline 02019.000146/2015-76 & 9268 & $E$ & Flora & $27 / 01 / 2015$ & $\mathrm{R} \$ 100.000,00$ & ALTINHO & 2015 \\
\hline 02019.000268/2015-62 & 7181 & $E$ & Fauna & $29 / 01 / 2015$ & $\mathrm{R} \$ 1.500,00$ & RECIFE & 2015 \\
\hline 02019.000249/2015-36 & 7182 & $E$ & Fauna & $29 / 01 / 2015$ & $\mathrm{R} \$ 500,00$ & RECIFE & 2015 \\
\hline 02019.000151/2015-89 & 9270 & $E$ & Fauna & $30 / 01 / 2015$ & $\mathrm{R} \$ 470.000,00$ & OLINDA & 2015 \\
\hline 02019.000172/2015-02 & 9271 & $E$ & Flora & 04/02/2015 & $\mathrm{R} \$ 5.000,00$ & CARNAIBA & 2015 \\
\hline 02019.000193/2015-10 & 9051564 & $E$ & Pesca & $05 / 02 / 2015$ & $\mathrm{R} \$ 1.320,00$ & RIO FORMOSO & 2015 \\
\hline 02019.000173/2015-49 & 8901 & $E$ & Pesca & 05/02/2015 & $\mathrm{R} \$ 840,00$ & RIO FORMOSO & 2015 \\
\hline 02019.000243/2015-69 & 9092657 & $E$ & Pesca & $10 / 02 / 2015$ & $\mathrm{R} \$ 10.320,00$ & RECIFE & 2015 \\
\hline $02019.000245 / 2015-58$ & 9092656 & $E$ & Pesca & $10 / 02 / 2015$ & $\mathrm{R} \$ 5.340,00$ & RECIFE & 2015 \\
\hline 02019.000206/2015-51 & 8913 & $E$ & Pesca & $10 / 02 / 2015$ & $\mathrm{R} \$ 5.340,00$ & RECIFE & 2015 \\
\hline 02019.000308/2015-76 & 9092658 & $E$ & Pesca & $12 / 02 / 2015$ & $\mathrm{R} \$ 5.600,00$ & RECIFE & 2015 \\
\hline 02019.000267/2015-18 & 9091668 & $E$ & Fauna & $21 / 02 / 2015$ & $\mathrm{R} \$ 1.060,00$ & GOIANA & 2015 \\
\hline 02019.000294/2015-91 & 9091667 & $E$ & Pesca & $21 / 02 / 2015$ & $\mathrm{R} \$ 1.100,00$ & GOIANA & 2015 \\
\hline 02019.000307/2015-21 & 8916 & $E$ & Pesca & $22 / 02 / 2015$ & $\mathrm{R} \$ 720,00$ & PETROLINA & 2015 \\
\hline $02019.000301 / 2015-54$ & 9051624 & $E$ & Pesca & 22/02/2015 & $\mathrm{R} \$ 700,00$ & PETROLINA & 2015 \\
\hline 02019.000314/2015-23 & 9095778 & $E$ & Flora & $27 / 02 / 2015$ & $\mathrm{R} \$ 10.000,00$ & IPOJUCA & 2015 \\
\hline 02019.000313/2015-89 & 743041 & $\mathrm{D}$ & Pesca & $27 / 02 / 2015$ & $\mathrm{R} \$ 10.000,00$ & IPOJUCA & 2015 \\
\hline 02019.000319/2015-56 & 7183 & $E$ & Fauna & $04 / 03 / 2015$ & $\mathrm{R} \$ 12.000,00$ & CAMARAGIBE & 2015 \\
\hline 02019.000319/2015-56 & 7183 & $E$ & Fauna & 04/03/2015 & $\mathrm{R} \$ 12.000,00$ & CAMARAGIBE & 2015 \\
\hline 02001.002721/2015-64 & 9095420 & $E$ & $\begin{array}{l}\text { Org. Gen. Modific. e } \\
\text { Biopirataria }\end{array}$ & $04 / 03 / 2015$ & $\mathrm{R} \$ 600.500,00$ & SALGUEIRO & 2015 \\
\hline 02001.002724/2015-06 & 9095419 & $E$ & $\begin{array}{l}\text { Org. Gen. Modific. e } \\
\text { Biopirataria }\end{array}$ & $04 / 03 / 2015$ & $\mathrm{R} \$ 400.500,00$ & SALGUEIRO & 2015 \\
\hline 02001.002722/2015-17 & 9095418 & $E$ & $\begin{array}{l}\text { Org. Gen. Modific. e } \\
\text { Biopirataria }\end{array}$ & $04 / 03 / 2015$ & $\mathrm{R} \$ 386.500,00$ & SALGUEIRO & 2015 \\
\hline 02001.002728/2015-86 & 9095417 & $E$ & $\begin{array}{l}\text { Org. Gen. Modific. e } \\
\text { Biopirataria }\end{array}$ & 04/03/2015 & $\mathrm{R} \$ 374.500,00$ & SALGUEIRO & 2015 \\
\hline 02019.000320/2015-81 & 9049717 & $E$ & $\begin{array}{l}\text { Org. Gen. Modific. e } \\
\text { Biopirataria }\end{array}$ & 05/03/2015 & $\mathrm{R} \$ 1.500,00$ & $\begin{array}{l}\text { CABO DE SANTO } \\
\text { AGOSTINHO }\end{array}$ & 2015 \\
\hline 02019.000589/2015-67 & 9074146 & $E$ & Fauna & $09 / 03 / 2015$ & $\mathrm{R} \$ 4.500,00$ & SALGUEIRO & 2015 \\
\hline 02019.000405/2015-69 & 9051626 & $E$ & $\begin{array}{l}\text { Org. Gen. Modific. e } \\
\text { Biopirataria }\end{array}$ & 09/03/2015 & $\mathrm{R} \$ 20.000,00$ & BARREIROS & 2015 \\
\hline
\end{tabular}




\begin{tabular}{|c|c|c|c|c|c|c|c|}
\hline 02019.000360/2015-22 & 9051627 & $E$ & Controle ambiental & $10 / 03 / 2015$ & $\mathrm{R} \$ 5.000,00$ & XEXEU & 2015 \\
\hline 02019.000387/2015-15 & 9051630 & $E$ & Controle ambiental & $10 / 03 / 2015$ & $\mathrm{R} \$ 2.500,00$ & XEXEU & 2015 \\
\hline 02019.000361/2015-77 & 9051629 & $E$ & Controle ambiental & $10 / 03 / 2015$ & $\mathrm{R} \$ 900,00$ & XEXEU & 2015 \\
\hline 02019.000364/2015-19 & 9095777 & $E$ & $\begin{array}{l}\text { Cadastro Técnico } \\
\text { Federal }\end{array}$ & $12 / 03 / 2015$ & $\mathrm{R} \$ 2.000,00$ & GOIANA & 2015 \\
\hline 02019.000385/2015-26 & 9051633 & $E$ & Controle ambiental & $12 / 03 / 2015$ & $\mathrm{R} \$ 2.500,00$ & BARREIROS & 2015 \\
\hline 02019.000407/2015-58 & 9051636 & $E$ & Controle ambiental & $12 / 03 / 2015$ & $\mathrm{R} \$ 2.500,00$ & CATENDE & 2015 \\
\hline 02019.000384/2015-81 & 7184 & $E$ & Flora & $12 / 03 / 2015$ & $\mathrm{R} \$ 500,00$ & IPOJUCA & 2015 \\
\hline 02019.000422/2015-04 & 9049435 & $E$ & Flora & $30 / 03 / 2015$ & $R \$ 5.000,00$ & $\begin{array}{l}\text { SAO LOURENCO DA } \\
\text { MATA }\end{array}$ & 2015 \\
\hline 02016.000519/2015-39 & 9061677 & $E$ & Controle ambiental & 06/04/2015 & $\mathrm{R} \$ 20.000,00$ & ITAMBE & 2015 \\
\hline 02019.000639/2015-14 & 9074147 & $E$ & Fauna & $06 / 04 / 2015$ & $R \$ 15.500,00$ & $\begin{array}{l}\text { SANTA MARIA DA } \\
\text { BOA VISTA }\end{array}$ & 2015 \\
\hline 02019.000911/2015-58 & 9074148 & E & Fauna & 07/04/2015 & $\mathrm{R} \$ 5.000,00$ & $\begin{array}{l}\text { SANTA MARIA DA } \\
\text { BOA VISTA }\end{array}$ & 2015 \\
\hline 02019.000912/2015-01 & 9074149 & E & Fauna & 07/04/2015 & $\mathrm{R} \$ 5.000,00$ & $\begin{array}{l}\text { SANTA MARIA DA } \\
\text { BOA VISTA }\end{array}$ & 2015 \\
\hline 02019.000913/2015-47 & 9074150 & E & Fauna & 07/04/2015 & $\mathrm{R} \$ 5.000,00$ & $\begin{array}{l}\text { SANTA MARIA DA } \\
\text { BOA VISTA }\end{array}$ & 2015 \\
\hline 02019.000590/2015-91 & 9074151 & $E$ & Fauna & 08/04/2015 & $\mathrm{R} \$ 5.000,00$ & FLORESTA & 2015 \\
\hline 02019.000641/2015-85 & 9074153 & $E$ & Flora & $08 / 04 / 2015$ & $\mathrm{R} \$ 900,00$ & LAGOA GRANDE & 2015 \\
\hline 02019.000640/2015-31 & 9074152 & $E$ & Flora & 08/04/2015 & $\mathrm{R} \$ 600,00$ & LAGOA GRANDE & 2015 \\
\hline 02019.000515/2015-21 & 8947 & $E$ & $\begin{array}{l}\text { Org. Gen. Modific. e } \\
\text { Biopirataria }\end{array}$ & $08 / 04 / 2015$ & $\mathrm{R} \$ 30.000,00$ & $\begin{array}{l}\text { JABOATAO DOS } \\
\text { GUARARAPES }\end{array}$ & 2015 \\
\hline 02004.000159/2015-12 & 9081927 & $E$ & Flora & $13 / 04 / 2015$ & $\mathrm{R} \$ 11.500,00$ & GARANHUNS & 2015 \\
\hline 02019.000539/2015-80 & 9756 & $E$ & Fauna & $15 / 04 / 2015$ & $\mathrm{R} \$ 14.000,00$ & RECIFE & 2015 \\
\hline 02019.000538/2015-35 & 8907 & $E$ & Fauna & $15 / 04 / 2015$ & $\mathrm{R} \$ 500,00$ & RECIFE & 2015 \\
\hline 02019.000536/2015-46 & 7185 & $E$ & Flora & $16 / 04 / 2015$ & $\mathrm{R} \$ 500,00$ & ABREU E LIMA & 2015 \\
\hline 02019.000537/2015-91 & 7186 & $E$ & Flora & $17 / 04 / 2015$ & $\mathrm{R} \$ 500,00$ & $\begin{array}{l}\text { JABOATAO DOS } \\
\text { GUARARAPES }\end{array}$ & 2015 \\
\hline 02019.000839/2015-69 & 742721 & D & Pesca & $18 / 04 / 2015$ & $\mathrm{R} \$ 2.300,00$ & RECIFE & 2015 \\
\hline $02019.000587 / 2015-78$ & 742722 & D & Pesca & $18 / 04 / 2015$ & $\mathrm{R} \$ 1.000,00$ & RECIFE & 2015 \\
\hline 02019.000793/2015-88 & 7187 & $E$ & Fauna & 23/04/2015 & $\mathrm{R} \$ 5.000,00$ & OLINDA & 2015 \\
\hline 02019.000794/2015-22 & 7188 & $E$ & Fauna & $23 / 04 / 2015$ & $\mathrm{R} \$ 500,00$ & $\begin{array}{l}\text { JABOATAO DOS } \\
\text { GUARARAPES }\end{array}$ & 2015 \\
\hline 02019.000597/2015-11 & 7189 & $E$ & $\begin{array}{l}\text { Cadastro Técnico } \\
\text { Federal }\end{array}$ & 28/04/2015 & $\mathrm{R} \$ 1.800,00$ & RECIFE & 2015 \\
\hline 02019.000642/2015-20 & 7190 & $E$ & Controle ambiental & $28 / 04 / 2015$ & $\mathrm{R} \$ 10.000,00$ & IGARASSU & 2015 \\
\hline 02019.000743/2015-09 & 9074154 & $E$ & Flora & 28/04/2015 & $\mathrm{R} \$ 1.500,00$ & SAO JOSE DO EGITO & 2015 \\
\hline 02019.000800/2015-41 & 9135 & $E$ & Fauna & 29/04/2015 & $\mathrm{R} \$ 179.000,00$ & RECIFE & 2015 \\
\hline 02019.000744/2015-45 & 9074155 & $E$ & Fauna & 29/04/2015 & $\mathrm{R} \$ 21.000,00$ & SERRA TALHADA & 2015 \\
\hline 02019.000643/2015-74 & 7191 & $E$ & Flora & 29/04/2015 & $\mathrm{R} \$ 5.000,00$ & JOAO ALFREDO & 2015 \\
\hline $02019.000602 / 2015-88$ & 9050558 & E & $\begin{array}{l}\text { Org. Gen. Modific. e } \\
\text { Biopirataria }\end{array}$ & $30 / 04 / 2015$ & $\mathrm{R} \$ 20.500,00$ & RECIFE & 2015 \\
\hline 02019.000692/2015-15 & 9051030 & $E$ & $\begin{array}{l}\text { Cadastro Técnico } \\
\text { Federal }\end{array}$ & $12 / 05 / 2015$ & $\mathrm{R} \$ 9.000,00$ & PAULISTA & 2015 \\
\hline $02019.000693 / 2015-51$ & 9051031 & E & $\begin{array}{l}\text { Cadastro Técnico } \\
\text { Federal }\end{array}$ & $12 / 05 / 2015$ & $\mathrm{R} \$ 9.000,00$ & FLORESTA & 2015 \\
\hline 02019.000694/2015-04 & 9051032 & E & $\begin{array}{l}\text { Cadastro Técnico } \\
\text { Federal }\end{array}$ & $12 / 05 / 2015$ & $\mathrm{R} \$ 9.000,00$ & $\begin{array}{l}\text { AFOGADOS DA } \\
\text { INGAZEIRA }\end{array}$ & 2015 \\
\hline 02019.000695/2015-41 & 9051033 & $E$ & $\begin{array}{l}\text { Cadastro Técnico } \\
\text { Federal }\end{array}$ & $12 / 05 / 2015$ & $\mathrm{R} \$ 1.800,00$ & GRAVATA & 2015 \\
\hline 02019.000716/2015-28 & 7283 & $E$ & $\begin{array}{l}\text { Cadastro Técnico } \\
\text { Federal }\end{array}$ & $12 / 05 / 2015$ & $\mathrm{R} \$ 1.800,00$ & RECIFE & 2015 \\
\hline 02019.000717/2015-72 & 7285 & $E$ & $\begin{array}{l}\text { Cadastro Técnico } \\
\text { Federal }\end{array}$ & $12 / 05 / 2015$ & $\mathrm{R} \$ 1.800,00$ & CANHOTINHO & 2015 \\
\hline 02019.000718/2015-17 & 7286 & $E$ & $\begin{array}{l}\text { Cadastro Técnico } \\
\text { Federal }\end{array}$ & $12 / 05 / 2015$ & $\mathrm{R} \$ 1.800,00$ & RECIFE & 2015 \\
\hline 02019.000914/2015-91 & 9074156 & $E$ & Fauna & $14 / 05 / 2015$ & $\mathrm{R} \$ 5.000,00$ & OURICURI & 2015 \\
\hline 02019.000764/2015-16 & 9074157 & $E$ & Flora & $18 / 05 / 2015$ & $\mathrm{R} \$ 4.950,00$ & OURICURI & 2015 \\
\hline 02019.000915/2015-36 & 9074158 & $E$ & Fauna & $19 / 05 / 2015$ & $\mathrm{R} \$ 500,00$ & ARARIPINA & 2015 \\
\hline 02019.000756/2015-70 & 7192 & $E$ & Flora & $20 / 05 / 2015$ & $\mathrm{R} \$ 500,00$ & RECIFE & 2015 \\
\hline 02019.000840/2015-93 & 9059 & $E$ & Fauna & $21 / 05 / 2015$ & $\mathrm{R} \$ 6.500,00$ & RECIFE & 2015 \\
\hline
\end{tabular}




\begin{tabular}{|c|c|c|c|c|c|c|c|}
\hline 02019.000757/2015-14 & 9060 & $E$ & Flora & $21 / 05 / 2015$ & $\mathrm{R} \$ 500,00$ & RECIFE & 2015 \\
\hline 02019.000841/2015-38 & 9061 & $E$ & Fauna & $22 / 05 / 2015$ & $\mathrm{R} \$ 7.000,00$ & RECIFE & 2015 \\
\hline 02019.000758/2015-69 & 9062 & $E$ & Fauna & $25 / 05 / 2015$ & $\mathrm{R} \$ 500,00$ & RECIFE & 2015 \\
\hline 02019.000759/2015-11 & 9063 & $E$ & Fauna & $25 / 05 / 2015$ & $\mathrm{R} \$ 500,00$ & RECIFE & 2015 \\
\hline 02019.000805/2015-74 & 9066 & $E$ & Fauna & $25 / 05 / 2015$ & $\mathrm{R} \$ 500,00$ & RECIFE & 2015 \\
\hline 02019.000806/2015-19 & 9068 & $E$ & Fauna & $25 / 05 / 2015$ & $\mathrm{R} \$ 500,00$ & RECIFE & 2015 \\
\hline 02019.000804/2015-20 & 9064 & $E$ & Flora & $25 / 05 / 2015$ & $R \$ 500,00$ & RECIFE & 2015 \\
\hline 02019.000803/2015-85 & 9065 & $E$ & Flora & $25 / 05 / 2015$ & $\mathrm{R} \$ 500,00$ & RECIFE & 2015 \\
\hline $02019.000762 / 2015-27$ & 9069 & $E$ & Fauna & $26 / 05 / 2015$ & $\mathrm{R} \$ 500,00$ & RECIFE & 2015 \\
\hline 02019.000798/2015-19 & 9072 & $E$ & Fauna & $26 / 05 / 2015$ & $\mathrm{R} \$ 500,00$ & RECIFE & 2015 \\
\hline 02019.000807/2015-63 & 9075 & $E$ & Fauna & $26 / 05 / 2015$ & $\mathrm{R} \$ 500,00$ & RECIFE & 2015 \\
\hline 02019.000796/2015-11 & 9070 & $E$ & Flora & $26 / 05 / 2015$ & $\mathrm{R} \$ 500,00$ & RECIFE & 2015 \\
\hline 02019.000799/2015-55 & 9073 & $E$ & Flora & $26 / 05 / 2015$ & $R \$ 500,00$ & RECIFE & 2015 \\
\hline 02019.000795/2015-77 & 9067 & $E$ & Fauna & $27 / 05 / 2015$ & $\mathrm{R} \$ 500,00$ & RECIFE & 2015 \\
\hline 02019.000797/2015-66 & 9071 & $E$ & Flora & $27 / 05 / 2015$ & $\mathrm{R} \$ 500,00$ & RECIFE & 2015 \\
\hline 02019.000916/2015-81 & 9074159 & $E$ & Fauna & 29/05/2015 & $\mathrm{R} \$ 9.500,00$ & SALGUEIRO & 2015 \\
\hline 02019.000821/2015-67 & 9049465 & $E$ & Fauna & $02 / 06 / 2015$ & $\mathrm{R} \$ 500,00$ & RECIFE & 2015 \\
\hline 02019.000822/2015-10 & 9051034 & $E$ & Pesca & $02 / 06 / 2015$ & $\mathrm{R} \$ 22.340,00$ & RECIFE & 2015 \\
\hline 02019.000892/2015-60 & 9077 & $E$ & Flora & $05 / 06 / 2015$ & $\mathrm{R} \$ 500,00$ & RECIFE & 2015 \\
\hline 02019.000893/2015-12 & 9078 & $E$ & Fauna & $08 / 06 / 2015$ & $\mathrm{R} \$ 500,00$ & RECIFE & 2015 \\
\hline 02019.000856/2015-04 & 9079 & $E$ & Fauna & $08 / 06 / 2015$ & $R \$ 500,00$ & RECIFE & 2015 \\
\hline 02019.000857/2015-41 & 9080 & $E$ & Fauna & 08/06/2015 & $R \$ 500,00$ & RECIFE & 2015 \\
\hline 02019.001078/2015-62 & 9074160 & $E$ & Controle ambiental & 09/06/2015 & $R \$ 500,00$ & LAGOA GRANDE & 2015 \\
\hline 02019.000842/2015-82 & 9082 & $E$ & Fauna & 09/06/2015 & $R \$ 500,00$ & RECIFE & 2015 \\
\hline $02019.000843 / 2015-27$ & 9083 & $E$ & Fauna & 09/06/2015 & $R \$ 500,00$ & RECIFE & 2015 \\
\hline 02019.000858/2015-95 & 9084 & $E$ & Fauna & 09/06/2015 & $\mathrm{R} \$ 500,00$ & RECIFE & 2015 \\
\hline 02019.000891/2015-15 & 9076 & $E$ & $\begin{array}{l}\text { Org. Gen. Modific. e } \\
\text { Biopirataria }\end{array}$ & $12 / 06 / 2015$ & $\mathrm{R} \$ 50.500,00$ & SIRINHAEM & 2015 \\
\hline 02019.000894/2015-59 & 9081 & $E$ & $\begin{array}{l}\text { Cadastro Técnico } \\
\text { Federal }\end{array}$ & $15 / 06 / 2015$ & $\mathrm{R} \$ 2.000,00$ & TORITAMA & 2015 \\
\hline 02019.000909/2015-89 & 9085 & $E$ & Fauna & $17 / 06 / 2015$ & $R \$ 500,00$ & ABREU E LIMA & 2015 \\
\hline 02019.001079/2015-15 & 9074161 & $E$ & Flora & $19 / 06 / 2015$ & $R \$ 5.000,00$ & $\begin{array}{l}\text { BELEM DE SAO } \\
\text { FRANCISCO }\end{array}$ & 2015 \\
\hline 02019.001080/2015-31 & 9074162 & $E$ & Flora & $19 / 06 / 2015$ & $\mathrm{R} \$ 1.500,00$ & $\begin{array}{l}\text { BELEM DE SAO } \\
\text { FRANCISCO }\end{array}$ & 2015 \\
\hline 02019.001099/2015-88 & 9074163 & $E$ & Flora & $22 / 06 / 2015$ & $\mathrm{R} \$ 1.500,00$ & SALGUEIRO & 2015 \\
\hline 02019.001006/2015-15 & 9186 & $E$ & Flora & $01 / 07 / 2015$ & $\mathrm{R} \$ 21.000,00$ & VERTENTES & 2015 \\
\hline 02019.001222/2015-61 & 9132 & $E$ & Controle ambiental & 02/07/2015 & $\mathrm{R} \$ 10.000,00$ & PARANATAMA & 2015 \\
\hline 02019.001019/2015-94 & 9133 & $E$ & $\begin{array}{l}\text { Org. Gen. Modific. e } \\
\text { Biopirataria }\end{array}$ & $03 / 07 / 2015$ & $\mathrm{R} \$ 1.500,00$ & GARANHUNS & 2015 \\
\hline 02019.001021/2015-63 & 9134 & $E$ & Flora & 06/07/2015 & $\mathrm{R} \$ 3.000,00$ & ARARIPINA & 2015 \\
\hline $02019.001018 / 2015-40$ & 9138 & $E$ & Flora & $07 / 07 / 2015$ & $\mathrm{R} \$ 17.604,00$ & ARARIPINA & 2015 \\
\hline 02019.001077/2015-18 & 9137 & $E$ & Flora & $07 / 07 / 2015$ & $\mathrm{R} \$ 15.000,00$ & ARARIPINA & 2015 \\
\hline 02019.001034/2015-32 & 7269 & $E$ & $\begin{array}{l}\text { Cadastro Técnico } \\
\text { Federal }\end{array}$ & $08 / 07 / 2015$ & $\mathrm{R} \$ 7.500,00$ & CACHOEIRINHA & 2015 \\
\hline 02019.001039/2015-65 & 8919 & $E$ & Pesca & $10 / 07 / 2015$ & $\mathrm{R} \$ 5.200,00$ & $\begin{array}{l}\text { SAO JOSE DA } \\
\text { COROA GRANDE }\end{array}$ & 2015 \\
\hline 02019.001036/2015-21 & 8918 & $E$ & Pesca & $10 / 07 / 2015$ & $\mathrm{R} \$ 1.200,00$ & $\begin{array}{l}\text { SAO JOSE DA } \\
\text { COROA GRANDE }\end{array}$ & 2015 \\
\hline 02016.000762/2015-57 & 9056471 & $E$ & $\begin{array}{l}\text { Cadastro Técnico } \\
\text { Federal }\end{array}$ & $21 / 07 / 2015$ & $\mathrm{R} \$ 9.000,00$ & RECIFE & 2015 \\
\hline 02019.001112/2015-07 & 9051035 & $E$ & Pesca & $23 / 07 / 2015$ & $\mathrm{R} \$ 5.200,00$ & GOIANA & 2015 \\
\hline 02019.001170/2015-22 & 7277 & $E$ & $\begin{array}{l}\text { Cadastro Técnico } \\
\text { Federal }\end{array}$ & $27 / 07 / 2015$ & $\mathrm{R} \$ 900,00$ & PRIMAVERA & 2015 \\
\hline $02019.001127 / 2015-67$ & 9139 & $E$ & Fauna & $04 / 08 / 2015$ & $\mathrm{R} \$ 3.500,00$ & MORENO & 2015 \\
\hline 02019.001245/2015-75 & 9088 & $E$ & Flora & 06/08/2015 & $\mathrm{R} \$ 3.000,00$ & EXU & 2015 \\
\hline $02019.001212 / 2015-25$ & 9089 & $E$ & Controle ambiental & $07 / 08 / 2015$ & $\mathrm{R} \$ 12.000,00$ & PETROLINA & 2015 \\
\hline 02019.001224/2015-50 & 9091 & $E$ & Controle ambiental & $10 / 08 / 2015$ & $\mathrm{R} \$ 12.000,00$ & $\begin{array}{l}\text { AFOGADOS DA } \\
\text { INGAZEIRA }\end{array}$ & 2015 \\
\hline $02019.001221 / 2015-16$ & 9090 & $E$ & Flora & $10 / 08 / 2015$ & $\mathrm{R} \$ 12.000,00$ & SERTANIA & 2015 \\
\hline 02019.001220/2015-71 & 9093 & $E$ & Flora & $14 / 08 / 2015$ & $\mathrm{R} \$ 900,00$ & CARUARU & 2015 \\
\hline
\end{tabular}




\begin{tabular}{|c|c|c|c|c|c|c|c|}
\hline 02019.001298/2015-96 & 9074142 & $E$ & $\begin{array}{l}\text { Org. Gen. Modific. e } \\
\text { Biopirataria }\end{array}$ & $14 / 08 / 2015$ & $\mathrm{R} \$ 11.500,00$ & $\begin{array}{l}\text { BELEM DE SAO } \\
\text { FRANCISCO }\end{array}$ & 2015 \\
\hline 02019.001213/2015-70 & 9092 & $E$ & $\begin{array}{l}\text { Org. Gen. Modific. e } \\
\text { Biopirataria }\end{array}$ & $14 / 08 / 2015$ & $\mathrm{R} \$ 1.500,00$ & CARUARU & 2015 \\
\hline 02019.001351/2015-59 & 9074144 & $E$ & Flora & $17 / 08 / 2015$ & $\mathrm{R} \$ 10.500,00$ & PETROLINA & 2015 \\
\hline $02019.001214 / 2015-14$ & 9094 & $E$ & Flora & $18 / 08 / 2015$ & $\mathrm{R} \$ 12.000,00$ & SERTANIA & 2015 \\
\hline 02019.001243/2015-86 & 9095 & $E$ & Flora & $18 / 08 / 2015$ & $\mathrm{R} \$ 11.000,00$ & PETROLINA & 2015 \\
\hline 02019.001215/2015-69 & 9049451 & $E$ & $\begin{array}{l}\text { Cadastro Técnico } \\
\text { Federal }\end{array}$ & 20/08/2015 & $\mathrm{R} \$ 2.000,00$ & RECIFE & 2015 \\
\hline 02019.001338/2015-08 & 9087 & $E$ & Fauna & $27 / 08 / 2015$ & $R \$ 500,00$ & RECIFE & 2015 \\
\hline 02019.001304/2015-13 & 9096 & $E$ & Fauna & $27 / 08 / 2015$ & $R \$ 500,00$ & BELO JARDIM & 2015 \\
\hline 02019.001310/2015-62 & 9104356 & $E$ & Fauna & $27 / 08 / 2015$ & $\mathrm{R} \$ 500,00$ & RECIFE & 2015 \\
\hline 02019.001306/2015-02 & 9049469 & $E$ & Flora & $31 / 08 / 2015$ & $\mathrm{R} \$ 9.000,00$ & TAMANDARE & 2015 \\
\hline 02019.001311/2015-15 & 9140 & $E$ & Flora & $31 / 08 / 2015$ & $\mathrm{R} \$ 8.700,00$ & $\begin{array}{l}\text { JABOATAO DOS } \\
\text { GUARARAPES }\end{array}$ & 2015 \\
\hline 02019.001305/2015-50 & 7078 & $E$ & $\begin{array}{l}\text { Cadastro Técnico } \\
\text { Federal }\end{array}$ & $01 / 09 / 2015$ & $\mathrm{R} \$ 900,00$ & ILHA DE ITAMARACA & 2015 \\
\hline $02019.001268 / 2015-80$ & 8930 & $E$ & Controle ambiental & $01 / 09 / 2015$ & $R \$ 10.000,00$ & IPOJUCA & 2015 \\
\hline 02019.001282/2015-83 & 9051038 & $E$ & Fauna & $02 / 09 / 2015$ & $\mathrm{R} \$ 500,00$ & RECIFE & 2015 \\
\hline 02019.001283/2015-28 & 9051039 & $E$ & Flora & 02/09/2015 & $R \$ 500,00$ & $\begin{array}{l}\text { JABOATAO DOS } \\
\text { GUARARAPES }\end{array}$ & 2015 \\
\hline 02019.001369/2015-51 & 9141 & $E$ & Fauna & 03/09/2015 & $\mathrm{R} \$ 26.000,00$ & AMARAJI & 2015 \\
\hline 02019.001448/2015-61 & 9074143 & $E$ & Fauna & $09 / 09 / 2015$ & $\mathrm{R} \$ 8.500,00$ & FLORESTA & 2015 \\
\hline 02019.001449/2015-14 & 9074145 & $E$ & Flora & $10 / 09 / 2015$ & $\mathrm{R} \$ 2.700,00$ & IBIMIRIM & 2015 \\
\hline 02019.001456/2015-16 & 9091663 & $E$ & Flora & $10 / 09 / 2015$ & $\mathrm{R} \$ 2.100,00$ & IBIMIRIM & 2015 \\
\hline 02019.001336/2015-19 & 9049475 & $E$ & Flora & $11 / 09 / 2015$ & $\mathrm{R} \$ 6.300,00$ & GRAVATA & 2015 \\
\hline 02016.001026/2015-16 & 3064 & $E$ & Flora & $14 / 09 / 2015$ & $\mathrm{R} \$ 45.000,00$ & VERTENTE DO LERIO & 2015 \\
\hline 02019.001337/2015-55 & 9142 & $E$ & Flora & $14 / 09 / 2015$ & $\mathrm{R} \$ 8.100,00$ & RECIFE & 2015 \\
\hline $02016.001027 / 2015-61$ & 3065 & $E$ & Outras & $14 / 09 / 2015$ & $\mathrm{R} \$ 500,00$ & VERTENTE DO LERIO & 2015 \\
\hline 02016.001069/2015-00 & 9056490 & $E$ & $\begin{array}{l}\text { Cadastro Técnico } \\
\text { Federal }\end{array}$ & $16 / 09 / 2015$ & $\mathrm{R} \$ 3.000,00$ & VERTENTE DO LERIO & 2015 \\
\hline 02016.001074/2015-12 & 9056489 & $E$ & $\begin{array}{l}\text { Cadastro Técnico } \\
\text { Federal }\end{array}$ & $16 / 09 / 2015$ & $\mathrm{R} \$ 1.100,00$ & $\begin{array}{l}\text { SANTA MARIA DO } \\
\text { CAMBUCA }\end{array}$ & 2015 \\
\hline 02016.001071/2015-71 & 9056487 & $E$ & Outras & $16 / 09 / 2015$ & $R \$ 10.500,00$ & $\begin{array}{l}\text { SANTA MARIA DO } \\
\text { CAMBUCA }\end{array}$ & 2015 \\
\hline 02016.001068/2015-57 & 9056491 & $E$ & Flora & $17 / 09 / 2015$ & $\mathrm{R} \$ 9.000,00$ & $\begin{array}{l}\text { SANTA MARIA DO } \\
\text { CAMBUCA }\end{array}$ & 2015 \\
\hline 02016.001063/2015-24 & 9056494 & $E$ & Outras & $17 / 09 / 2015$ & $\mathrm{R} \$ 3.000,00$ & $\begin{array}{l}\text { SANTA MARIA DO } \\
\text { CAMBUCA }\end{array}$ & 2015 \\
\hline 02016.001075/2015-59 & 9056492 & $E$ & Outras & $17 / 09 / 2015$ & $\mathrm{R} \$ 1.000,00$ & $\begin{array}{l}\text { SANTA MARIA DO } \\
\text { CAMBUCA }\end{array}$ & 2015 \\
\hline 02019.001477/2015-23 & 9143 & $E$ & Fauna & $18 / 09 / 2015$ & $\mathrm{R} \$ 4.000,00$ & $\begin{array}{l}\text { VITORIA DE SANTO } \\
\text { ANTAO }\end{array}$ & 2015 \\
\hline 02019.001478/2015-78 & 9144 & $E$ & Fauna & $19 / 09 / 2015$ & $\mathrm{R} \$ 9.000,00$ & GARANHUNS & 2015 \\
\hline 02019.001476/2015-89 & 9052196 & $E$ & Fauna & $19 / 09 / 2015$ & $\mathrm{R} \$ 5.000,00$ & GARANHUNS & 2015 \\
\hline 02019.001485/2015-70 & 9104357 & $E$ & Fauna & $19 / 09 / 2015$ & $\mathrm{R} \$ 2.000,00$ & GARANHUNS & 2015 \\
\hline 02019.001471/2015-56 & 9049466 & $E$ & Fauna & 19/09/2015 & $\mathrm{R} \$ 2.000,00$ & GARANHUNS & 2015 \\
\hline 02019.001482/2015-36 & 9104358 & $E$ & Fauna & $20 / 09 / 2015$ & $\mathrm{R} \$ 17.000,00$ & ARCOVERDE & 2015 \\
\hline 02019.001475/2015-34 & 9049822 & $E$ & Fauna & 20/09/2015 & $\mathrm{R} \$ 5.000,00$ & ARCOVERDE & 2015 \\
\hline 02019.001483/2015-81 & 9146 & $E$ & Fauna & $20 / 09 / 2015$ & $\mathrm{R} \$ 3.000,00$ & ARCOVERDE & 2015 \\
\hline 02019.001472/2015-09 & 9049471 & $E$ & Fauna & 20/09/2015 & $\mathrm{R} \$ 500,00$ & ARCOVERDE & 2015 \\
\hline 02019.001474/2015-90 & 9049787 & $E$ & Fauna & $20 / 09 / 2015$ & $R \$ 500,00$ & ARCOVERDE & 2015 \\
\hline $02019.001484 / 2015-25$ & 9104359 & $E$ & Fauna & $21 / 09 / 2015$ & $\mathrm{R} \$ 4.500,00$ & BELO JARDIM & 2015 \\
\hline 02019.001450/2015-31 & 9091664 & $E$ & Fauna & $22 / 09 / 2015$ & $\mathrm{R} \$ 10.000,00$ & SERRA TALHADA & 2015 \\
\hline 02019.001451/2015-85 & 9100941 & $E$ & Fauna & $24 / 09 / 2015$ & $\mathrm{R} \$ 9.500,00$ & SALGUEIRO & 2015 \\
\hline $02019.001452 / 2015-20$ & 9100942 & $E$ & Fauna & $30 / 09 / 2015$ & $\mathrm{R} \$ 33.000,00$ & BUIQUE & 2015 \\
\hline 02019.001453/2015-74 & 9100943 & $E$ & Fauna & $30 / 09 / 2015$ & $\mathrm{R} \$ 12.000,00$ & BUIQUE & 2015 \\
\hline $02019.001473 / 2015-45$ & 9049473 & $E$ & Fauna & $30 / 09 / 2015$ & $\mathrm{R} \$ 3.500,00$ & LAJEDO & 2015 \\
\hline 02019.001523/2015-94 & 9100944 & $E$ & Flora & 06/10/2015 & $\mathrm{R} \$ 1.000,00$ & EXU & 2015 \\
\hline 02019.001524/2015-39 & 9100945 & $E$ & Flora & $07 / 10 / 2015$ & $\mathrm{R} \$ 2.000,00$ & ARARIPINA & 2015 \\
\hline 02019.001525/2015-83 & 9100946 & $E$ & Flora & 08/10/2015 & $\mathrm{R} \$ 3.000,00$ & TRINDADE & 2015 \\
\hline $02019.001526 / 2015-28$ & 9100947 & $E$ & Flora & $08 / 10 / 2015$ & $\mathrm{R} \$ 3.000,00$ & TRINDADE & 2015 \\
\hline
\end{tabular}




\begin{tabular}{|c|c|c|c|c|c|c|c|}
\hline 02019.001480/2015-47 & 9145 & $E$ & Outras & 08/10/2015 & $\mathrm{R} \$ 10.500,00$ & IPOJUCA & 2015 \\
\hline 02019.001647/2015-70 & 9100949 & $E$ & Flora & $13 / 10 / 2015$ & $\mathrm{R} \$ 3.500,00$ & SALGUEIRO & 2015 \\
\hline $02019.001646 / 2015-25$ & 9100948 & $E$ & Flora & 13/10/2015 & $\mathrm{R} \$ 1.000,00$ & SALGUEIRO & 2015 \\
\hline 02019.001481/2015-91 & 9104360 & $E$ & $\begin{array}{l}\text { Cadastro Técnico } \\
\text { Federal }\end{array}$ & $14 / 10 / 2015$ & $\mathrm{R} \$ 9.000,00$ & RECIFE & 2015 \\
\hline 02019.001493/2015-16 & 9104362 & $E$ & Flora & $16 / 10 / 2015$ & $\mathrm{R} \$ 65.700,00$ & RECIFE & 2015 \\
\hline 02019.001492/2015-71 & 9104361 & $E$ & Flora & $16 / 10 / 2015$ & $\mathrm{R} \$ 6.300,00$ & RECIFE & 2015 \\
\hline 02019.001491/2015-27 & 7155 & $E$ & Flora & $16 / 10 / 2015$ & $\mathrm{R} \$ 4.800,00$ & RECIFE & 2015 \\
\hline 02019.001495/2015-13 & 9151 & $E$ & Flora & 19/10/2015 & $\mathrm{R} \$ 34.500,00$ & RECIFE & 2015 \\
\hline \multirow[t]{3}{*}{ 02019.001494/2015-61 } & 7066 & $E$ & Flora & 19/10/2015 & $\mathrm{R} \$ 16.000,00$ & GRANITO & 2015 \\
\hline & 9051069 & $E$ & Fauna & $20 / 10 / 2015$ & $\mathrm{R} \$ 9.000,00$ & ABREU E LIMA & 2015 \\
\hline & 9047731 & $E$ & Fauna & 21/10/2015 & $\mathrm{R} \$ 5.000,00$ & BELO JARDIM & 2015 \\
\hline 02016.001173/2015-96 & 5360 & $E$ & Outras & $21 / 10 / 2015$ & $\mathrm{R} \$ 10.000,00$ & GOIANA & 2015 \\
\hline 02019.001649/2015-69 & 9100951 & $E$ & Flora & 23/10/2015 & $\mathrm{R} \$ 4.500,00$ & SALGUEIRO & 2015 \\
\hline \multirow[t]{2}{*}{ 02019.001648/2015-14 } & 9100950 & $E$ & Flora & 23/10/2015 & $\mathrm{R} \$ 2.000,00$ & SALGUEIRO & 2015 \\
\hline & 9147 & $E$ & Controle ambiental & 29/10/2015 & $\mathrm{R} \$ 1.500,00$ & $\begin{array}{l}\text { SAO VICENTE } \\
\text { FERRER }\end{array}$ & 2015 \\
\hline $02548.000145 / 2015-43$ & 9099115 & $E$ & Flora & $03 / 11 / 2015$ & $\mathrm{R} \$ 52.500,00$ & CUPIRA & 2015 \\
\hline 02019.001595/2015-31 & 9049470 & $\mathrm{E}$ & $\begin{array}{l}\text { Cadastro Técnico } \\
\text { Federal }\end{array}$ & $11 / 11 / 2015$ & $\mathrm{R} \$ 1.800,00$ & RECIFE & 2015 \\
\hline 02019.001596/2015-86 & 9104363 & $E$ & Outras & $11 / 11 / 2015$ & $\mathrm{R} \$ 20.500,00$ & $\begin{array}{l}\text { JABOATAO DOS } \\
\text { GUARARAPES }\end{array}$ & 2015 \\
\hline 02019.001616/2015-19 & 7067 & $E$ & Fauna & 18/11/2015 & $\mathrm{R} \$ 2.000,00$ & RECIFE & 2015 \\
\hline $02019.001657 / 2015-13$ & 7070 & $E$ & Fauna & $19 / 11 / 2015$ & $\mathrm{R} \$ 5.000,00$ & RECIFE & 2015 \\
\hline 02019.001645/2015-81 & 8917 & $E$ & Fauna & 20/11/2015 & $\mathrm{R} \$ 5.000,00$ & RECIFE & 2015 \\
\hline 02019.001695/2015-68 & 8938 & $E$ & Fauna & $01 / 12 / 2015$ & $\mathrm{R} \$ 135.000,00$ & GRAVATA & 2015 \\
\hline 02019.001660/2015-29 & 9047738 & E & $\begin{array}{l}\text { Cadastro Técnico } \\
\text { Federal }\end{array}$ & 02/12/2015 & $\mathrm{R} \$ 5.000,00$ & BODOCO & 2015 \\
\hline 02019.000359/2016-89 & 9100958 & $E$ & Controle ambiental & $04 / 12 / 2015$ & $\mathrm{R} \$ 1.000,00$ & EXU & 2015 \\
\hline 02019.000356/2016-45 & 9100955 & $E$ & Fauna & 04/12/2015 & $\mathrm{R} \$ 500,00$ & EXU & 2015 \\
\hline 02019.000360/2016-11 & 9100960 & $E$ & Fauna & $04 / 12 / 2015$ & $\mathrm{R} \$ 500,00$ & EXU & 2015 \\
\hline 02019.000361/2016-58 & 9100961 & $E$ & Flora & 04/12/2015 & $\mathrm{R} \$ 10.000,00$ & EXU & 2015 \\
\hline 02019.000354/2016-56 & 9100952 & $E$ & $\begin{array}{l}\text { Unidades de } \\
\text { conservação }\end{array}$ & $04 / 12 / 2015$ & $\mathrm{R} \$ 1.000,00$ & EXU & 2015 \\
\hline 02019.000355/2016-09 & 9100953 & $E$ & $\begin{array}{l}\text { Unidades de } \\
\text { conservação }\end{array}$ & $04 / 12 / 2015$ & $\mathrm{R} \$ 1.000,00$ & EXU & 2015 \\
\hline 02019.000357/2016-90 & 9100956 & $E$ & $\begin{array}{l}\text { Unidades de } \\
\text { conservação }\end{array}$ & $04 / 12 / 2015$ & $\mathrm{R} \$ 1.000,00$ & EXU & 2015 \\
\hline 02019.000358/2016-34 & 9100957 & $E$ & $\begin{array}{l}\text { Unidades de } \\
\text { conservação }\end{array}$ & $04 / 12 / 2015$ & $\mathrm{R} \$ 1.000,00$ & EXU & 2015 \\
\hline 02019.000362/2016-01 & 9100962 & $E$ & Flora & $05 / 12 / 2015$ & $\mathrm{R} \$ 10.000,00$ & EXU & 2015 \\
\hline 02019.000363/2016-47 & 9100963 & $E$ & Fauna & $16 / 12 / 2015$ & $\mathrm{R} \$ 4.500,00$ & $\begin{array}{l}\text { SANTA CRUZ DA } \\
\text { BAIXA VERDE }\end{array}$ & 2015 \\
\hline 02019.000364/2016-91 & 9100964 & $E$ & Fauna & $16 / 12 / 2015$ & $\mathrm{R} \$ 1.500,00$ & SERRA TALHADA & 2015 \\
\hline 02019.000066/2016-00 & 7288 & $E$ & Fauna & $16 / 12 / 2015$ & $\mathrm{R} \$ 500,00$ & ABREU E LIMA & 2015 \\
\hline 02019.000067/2016-46 & 7210 & $E$ & Flora & $21 / 12 / 2015$ & $\mathrm{R} \$ 1.000,00$ & ARCOVERDE & 2015 \\
\hline 02019.000064/2016-11 & 8941 & $E$ & $\begin{array}{l}\text { Cadastro Técnico } \\
\text { Federal }\end{array}$ & $23 / 12 / 2015$ & $\mathrm{R} \$ 6.000,00$ & CARUARU & 2015 \\
\hline 02019.000069/2016-35 & 8939 & $E$ & $\begin{array}{l}\text { Cadastro Técnico } \\
\text { Federal }\end{array}$ & 23/12/2015 & $\mathrm{R} \$ 5.000,00$ & RECIFE & 2015 \\
\hline 02019.000070/2016-60 & 8940 & $E$ & $\begin{array}{l}\text { Cadastro Técnico } \\
\text { Federal }\end{array}$ & 23/12/2015 & $\mathrm{R} \$ 5.000,00$ & NAZARE DA MATA & 2015 \\
\hline 02019.000068/2016-91 & 8943 & $E$ & $\begin{array}{l}\text { Cadastro Técnico } \\
\text { Federal }\end{array}$ & $23 / 12 / 2015$ & $\mathrm{R} \$ 3.000,00$ & PETROLINA & 2015 \\
\hline 02019.000065/2016-57 & 8944 & $E$ & $\begin{array}{l}\text { Cadastro Técnico } \\
\text { Federal }\end{array}$ & $23 / 12 / 2015$ & $\mathrm{R} \$ 2.000,00$ & SAO JOSE DO EGITO & 2015 \\
\hline 02601.000012/2016-66 & 8551 & $E$ & Fauna & $24 / 12 / 2015$ & $\mathrm{R} \$ 1.500,00$ & PETROLINA & 2015 \\
\hline 02019.000071/2016-12 & 9050538 & $\mathrm{E}$ & Pesca & 06/01/2016 & $\mathrm{R} \$ 6.620,00$ & RECIFE & 2016 \\
\hline $02601.000004 / 2016-10$ & 9045443 & $E$ & Pesca & $08 / 01 / 2016$ & $\mathrm{R} \$ 2.660,00$ & LAGOA GRANDE & 2016 \\
\hline 02548.000016/2016-36 & 9099428 & $E$ & Flora & $13 / 01 / 2016$ & $\mathrm{R} \$ 111.500,00$ & CUPIRA & 2016 \\
\hline 02019.000093/2016-74 & 9104365 & $E$ & Pesca & $15 / 01 / 2016$ & $\mathrm{R} \$ 1.920,00$ & GOIANA & 2016 \\
\hline 02019.000091/2016-85 & 7073 & $\mathrm{E}$ & Pesca & $15 / 01 / 2016$ & $\mathrm{R} \$ 1.180,00$ & GOIANA & 2016 \\
\hline
\end{tabular}




\begin{tabular}{|c|c|c|c|c|c|c|c|}
\hline 02019.000090/2016-31 & 7074 & $E$ & Pesca & $15 / 01 / 2016$ & $\mathrm{R} \$ 960,00$ & GOIANA & 2016 \\
\hline 02019.000089/2016-14 & 7072 & $E$ & Pesca & $15 / 01 / 2016$ & $\mathrm{R} \$ 810,00$ & GOIANA & 2016 \\
\hline 02601.000010/2016-77 & 9045444 & $E$ & Pesca & $19 / 01 / 2016$ & $\mathrm{R} \$ 1.780,00$ & PETROLINA & 2016 \\
\hline 02019.000103/2016-71 & 9050539 & $E$ & $\begin{array}{l}\text { Cadastro Técnico } \\
\text { Federal }\end{array}$ & $22 / 01 / 2016$ & $\mathrm{R} \$ 5.000,00$ & $\begin{array}{l}\text { CABO DE SANTO } \\
\text { AGOSTINHO }\end{array}$ & 2016 \\
\hline 02019.000104/2016-16 & 9050541 & $E$ & $\begin{array}{l}\text { Cadastro Técnico } \\
\text { Federal }\end{array}$ & 22/01/2016 & $\mathrm{R} \$ 5.000,00$ & $\begin{array}{l}\text { BARRA DE } \\
\text { GUABIRABA }\end{array}$ & 2016 \\
\hline 02019.000135/2016-77 & 9049719 & $E$ & Pesca & 24/01/2016 & $\mathrm{R} \$ 1.160,00$ & IPOJUCA & 2016 \\
\hline 02019.000130/2016-44 & 7075 & $E$ & Pesca & $24 / 01 / 2016$ & $\mathrm{R} \$ 1.040,00$ & IPOJUCA & 2016 \\
\hline 02019.000115/2016-04 & 9152 & $E$ & Pesca & $25 / 01 / 2016$ & $\mathrm{R} \$ 5.080,00$ & IPOJUCA & 2016 \\
\hline 02019.000176/2016-63 & 9049727 & $E$ & Pesca & $25 / 01 / 2016$ & $\mathrm{R} \$ 1.100,00$ & IPOJUCA & 2016 \\
\hline 02019.000132/2016-33 & 9104366 & $E$ & Pesca & $25 / 01 / 2016$ & $\mathrm{R} \$ 1.080,00$ & IPOJUCA & 2016 \\
\hline 02019.000114/2016-51 & 9051586 & $E$ & Pesca & $25 / 01 / 2016$ & $\mathrm{R} \$ 1.080,00$ & IPOJUCA & 2016 \\
\hline 02019.000134/2016-22 & 9104367 & $E$ & Pesca & $25 / 01 / 2016$ & $\mathrm{R} \$ 1.080,00$ & IPOJUCA & 2016 \\
\hline 02019.000124/2016-97 & 9104368 & $E$ & Pesca & $26 / 01 / 2016$ & $\mathrm{R} \$ 1.450,00$ & TAMANDARE & 2016 \\
\hline 02019.000123/2016-42 & 9154 & $E$ & Pesca & $26 / 01 / 2016$ & $\mathrm{R} \$ 1.450,00$ & $\begin{array}{l}\text { SAO JOSE DA } \\
\text { COROA GRANDE }\end{array}$ & 2016 \\
\hline 02019.000175/2016-19 & 7076 & $E$ & Pesca & $26 / 01 / 2016$ & $\mathrm{R} \$ 1.102,00$ & SIRINHAEM & 2016 \\
\hline 02019.000128/2016-75 & 9049728 & $E$ & Pesca & $26 / 01 / 2016$ & $\mathrm{R} \$ 1.064,00$ & SIRINHAEM & 2016 \\
\hline 02019.000133/2016-88 & 7077 & $E$ & Pesca & $27 / 01 / 2016$ & $\mathrm{R} \$ 1.080,00$ & RIO FORMOSO & 2016 \\
\hline 02019.000129/2016-10 & 7080 & $E$ & Outras & 28/01/2016 & $\mathrm{R} \$ 50.500,00$ & TAMANDARE & 2016 \\
\hline 02601.000016/2016-44 & 9045446 & $E$ & Pesca & $28 / 01 / 2016$ & $\mathrm{R} \$ 1.500,00$ & PETROLINA & 2016 \\
\hline 02019.000365/2016-36 & 9100965 & $E$ & Pesca & 02/02/2016 & $\mathrm{R} \$ 1.580,00$ & CABROBO & 2016 \\
\hline 02019.000564/2016-44 & 9074164 & $E$ & Fauna & 03/02/2016 & $\mathrm{R} \$ 43.000,00$ & AFRANIO & 2016 \\
\hline 02019.000179/2016-05 & 9104369 & $E$ & Pesca & 03/02/2016 & $\mathrm{R} \$ 1.660,00$ & GOIANA & 2016 \\
\hline 02019.000305/2016-13 & 9051593 & $E$ & Pesca & 03/02/2016 & $\mathrm{R} \$ 1.360,00$ & GOIANA & 2016 \\
\hline 02019.000178/2016-52 & 9150 & $E$ & Pesca & 03/02/2016 & $\mathrm{R} \$ 1.360,00$ & GOIANA & 2016 \\
\hline 02019.000565/2016-99 & 9074165 & $E$ & Fauna & $04 / 02 / 2016$ & $\mathrm{R} \$ 2.000,00$ & AFRANIO & 2016 \\
\hline 02019.000283/2016-91 & 9074166 & $E$ & Fauna & 05/02/2016 & $\mathrm{R} \$ 16.500,00$ & $\begin{array}{l}\text { BELEM DE SAO } \\
\text { FRANCISCO }\end{array}$ & 2016 \\
\hline 02019.000304/2016-79 & 9050542 & $E$ & Fauna & $13 / 02 / 2016$ & $\mathrm{R} \$ 4.000,00$ & RECIFE & 2016 \\
\hline 02019.000307/2016-11 & 9155 & $E$ & $\begin{array}{l}\text { Cadastro Técnico } \\
\text { Federal }\end{array}$ & $15 / 02 / 2016$ & $\mathrm{R} \$ 5.000,00$ & $\begin{array}{l}\text { SAO JOSE DO } \\
\text { BELMONTE }\end{array}$ & 2016 \\
\hline 02019.000300/2016-91 & 9049730 & $E$ & Flora & $16 / 02 / 2016$ & $\mathrm{R} \$ 5.000,00$ & SERTANIA & 2016 \\
\hline 02019.000301/2016-35 & 9049731 & E & Flora & $16 / 02 / 2016$ & $\mathrm{R} \$ 5.000,00$ & $\begin{array}{l}\text { CABO DE SANTO } \\
\text { AGOSTINHO }\end{array}$ & 2016 \\
\hline 02019.000352/2016-67 & 9074167 & $E$ & Fauna & $17 / 02 / 2016$ & $\mathrm{R} \$ 11.000,00$ & TRIUNFO & 2016 \\
\hline 02019.000303/2016-24 & 9049733 & $E$ & Fauna & $18 / 02 / 2016$ & $\mathrm{R} \$ 21.000,00$ & BEZERROS & 2016 \\
\hline 02019.000353/2016-10 & 9074168 & $E$ & Fauna & $18 / 02 / 2016$ & $\mathrm{R} \$ 17.000,00$ & SERTANIA & 2016 \\
\hline 02019.000302/2016-80 & 9049732 & $E$ & Fauna & 18/02/2016 & $\mathrm{R} \$ 2.000,00$ & BEZERROS & 2016 \\
\hline 02019.000567/2016-88 & 9074170 & $E$ & Fauna & 22/02/2016 & $\mathrm{R} \$ 13.500,00$ & MIRANDIBA & 2016 \\
\hline 02019.000566/2016-33 & 9074169 & $E$ & Fauna & 22/02/2016 & $\mathrm{R} \$ 4.000,00$ & SAO JOSE DO EGITO & 2016 \\
\hline 02019.000299/2016-02 & 9049474 & $\mathrm{E}$ & Fauna & $23 / 02 / 2016$ & $\mathrm{R} \$ 12.500,00$ & $\begin{array}{l}\text { JABOATAO DOS } \\
\text { GUARARAPES }\end{array}$ & 2016 \\
\hline 02019.000478/2016-31 & 9050543 & E & $\begin{array}{l}\text { Cadastro Técnico } \\
\text { Federal }\end{array}$ & 25/02/2016 & $\mathrm{R} \$ 5.000,00$ & IPOJUCA & 2016 \\
\hline 02016.000351/2016-42 & 9048753 & $E$ & Fauna & $25 / 02 / 2016$ & $\mathrm{R} \$ 2.480,00$ & GOIANA & 2016 \\
\hline 02019.000347/2016-54 & 7079 & $E$ & Pesca & $25 / 02 / 2016$ & $\mathrm{R} \$ 1.400,00$ & RECIFE & 2016 \\
\hline 02019.000349/2016-43 & 9049738 & $E$ & Pesca & $25 / 02 / 2016$ & $\mathrm{R} \$ 1.120,00$ & RECIFE & 2016 \\
\hline 02019.000415/2016-85 & 9049735 & $E$ & Pesca & $25 / 02 / 2016$ & $\mathrm{R} \$ 1.060,00$ & RECIFE & 2016 \\
\hline 02019.000350/2016-78 & 9049740 & $\mathrm{E}$ & Pesca & $26 / 02 / 2016$ & $\mathrm{R} \$ 1.220,00$ & $\begin{array}{l}\text { JABOATAO DOS } \\
\text { GUARARAPES }\end{array}$ & 2016 \\
\hline 02019.000348/2016-07 & 7081 & $E$ & Pesca & 26/02/2016 & $\mathrm{R} \$ 1.060,00$ & IPOJUCA & 2016 \\
\hline 02016.000354/2016-86 & 9061772 & $E$ & Pesca & $27 / 02 / 2016$ & $\mathrm{R} \$ 4.540,00$ & ITAPISSUMA & 2016 \\
\hline 02016.000353/2016-31 & 9061771 & $E$ & Pesca & 27/02/2016 & $\mathrm{R} \$ 1.340,00$ & ITAPISSUMA & 2016 \\
\hline 02019.000351/2016-12 & 9049741 & $E$ & Pesca & 27/02/2016 & $\mathrm{R} \$ 1.196,00$ & RIO FORMOSO & 2016 \\
\hline 02019.000423/2016-21 & 9104370 & $E$ & Pesca & 27/02/2016 & $\mathrm{R} \$ 1.160,00$ & RIO FORMOSO & 2016 \\
\hline 02019.000340/2016-32 & 7082 & $E$ & Pesca & $27 / 02 / 2016$ & $\mathrm{R} \$ 1.100,00$ & RIO FORMOSO & 2016 \\
\hline 02019.000414/2016-31 & 9058 & $E$ & Pesca & 28/02/2016 & $\mathrm{R} \$ 1.280,00$ & IPOJUCA & 2016 \\
\hline 02019.000366/2016-81 & 9104371 & $E$ & Pesca & 28/02/2016 & $\mathrm{R} \$ 1.240,00$ & $\begin{array}{l}\text { CABO DE SANTO } \\
\text { AGOSTINHO }\end{array}$ & 2016 \\
\hline
\end{tabular}




\begin{tabular}{|c|c|c|c|c|c|c|c|}
\hline 02019.000418/2016-19 & 9050546 & $E$ & Fauna & 05/03/2016 & $\mathrm{R} \$ 47.000,00$ & IBIMIRIM & 2016 \\
\hline 02019.000416/2016-20 & 9050544 & $E$ & Fauna & 05/03/2016 & $\mathrm{R} \$ 34.000,00$ & IBIMIRIM & 2016 \\
\hline 02019.000876/2016-58 & 9074173 & $E$ & Fauna & 05/03/2016 & $\mathrm{R} \$ 34.000,00$ & IBIMIRIM & 2016 \\
\hline 02019.000880/2016-16 & 9074177 & $E$ & Fauna & 05/03/2016 & $\mathrm{R} \$ 32.000,00$ & IBIMIRIM & 2016 \\
\hline 02019.000875/2016-11 & 9074172 & $E$ & Fauna & 05/03/2016 & $\mathrm{R} \$ 31.000,00$ & IBIMIRIM & 2016 \\
\hline 02019.000877/2016-01 & 9074174 & $E$ & Fauna & 05/03/2016 & $\mathrm{R} \$ 28.500,00$ & IBIMIRIM & 2016 \\
\hline 02019.000419/2016-63 & 9050547 & $E$ & Fauna & 05/03/2016 & $\mathrm{R} \$ 27.500,00$ & IBIMIRIM & 2016 \\
\hline 02019.000422/2016-87 & 9050550 & $E$ & Fauna & $05 / 03 / 2016$ & $\mathrm{R} \$ 20.000,00$ & IBIMIRIM & 2016 \\
\hline 02019.000801/2016-77 & 9074171 & $E$ & Fauna & 05/03/2016 & $\mathrm{R} \$ 15.000,00$ & IBIMIRIM & 2016 \\
\hline 02019.000417/2016-74 & 9050545 & $E$ & Fauna & 05/03/2016 & $\mathrm{R} \$ 8.500,00$ & IBIMIRIM & 2016 \\
\hline 02019.000420/2016-98 & 9050548 & $E$ & Fauna & 05/03/2016 & $\mathrm{R} \$ 7.000,00$ & IBIMIRIM & 2016 \\
\hline 02019.000421/2016-32 & 9050549 & $E$ & Fauna & $05 / 03 / 2016$ & $\mathrm{R} \$ 7.000,00$ & IBIMIRIM & 2016 \\
\hline 02019.000879/2016-91 & 9074176 & $E$ & Fauna & 05/03/2016 & $\mathrm{R} \$ 5.000,00$ & IBIMIRIM & 2016 \\
\hline $02019.000878 / 2016-47$ & 9074175 & $E$ & Fauna & 05/03/2016 & $\mathrm{R} \$ 4.000,00$ & IBIMIRIM & 2016 \\
\hline 02019.000531/2016-02 & 9049734 & $E$ & Pesca & 05/03/2016 & $\mathrm{R} \$ 1.200,00$ & RECIFE & 2016 \\
\hline 02019.000530/2016-50 & 9049476 & $E$ & Pesca & $10 / 03 / 2016$ & $\mathrm{R} \$ 1.140,00$ & RECIFE & 2016 \\
\hline 02019.000546/2016-62 & 7083 & $E$ & Pesca & $11 / 03 / 2016$ & $\mathrm{R} \$ 1.360,00$ & SIRINHAEM & 2016 \\
\hline 02019.000479/2016-86 & 9156 & $E$ & Pesca & $11 / 03 / 2016$ & $\mathrm{R} \$ 1.200,00$ & RECIFE & 2016 \\
\hline 02019.000482/2016-08 & 9160 & $E$ & Fauna & $12 / 03 / 2016$ & $\mathrm{R} \$ 1.500,00$ & ITAPISSUMA & 2016 \\
\hline 02019.000535/2016-82 & 9158 & $E$ & Pesca & $12 / 03 / 2016$ & $\mathrm{R} \$ 2.120,00$ & ITAPISSUMA & 2016 \\
\hline 02019.000476/2016-42 & 7247 & $E$ & Pesca & $12 / 03 / 2016$ & $\mathrm{R} \$ 1.640,00$ & ITAPISSUMA & 2016 \\
\hline 02019.000481/2016-55 & 9159 & $E$ & Pesca & $12 / 03 / 2016$ & $\mathrm{R} \$ 1.460,00$ & ITAPISSUMA & 2016 \\
\hline 02019.000480/2016-19 & 9157 & $E$ & Pesca & $12 / 03 / 2016$ & $\mathrm{R} \$ 1.380,00$ & ITAPISSUMA & 2016 \\
\hline 02019.000532/2016-49 & 9049736 & $E$ & Pesca & $12 / 03 / 2016$ & $\mathrm{R} \$ 1.320,00$ & $\begin{array}{l}\text { CABO DE SANTO } \\
\text { AGOSTINHO }\end{array}$ & 2016 \\
\hline 02019.000533/2016-93 & 9049737 & $E$ & Pesca & $12 / 03 / 2016$ & $\mathrm{R} \$ 1.300,00$ & $\begin{array}{l}\text { CABO DE SANTO } \\
\text { AGOSTINHO }\end{array}$ & 2016 \\
\hline 02019.000475/2016-06 & 7246 & $E$ & Pesca & $12 / 03 / 2016$ & $\mathrm{R} \$ 1.240,00$ & ITAPISSUMA & 2016 \\
\hline 02019.000477/2016-97 & 7248 & $E$ & Pesca & $12 / 03 / 2016$ & $\mathrm{R} \$ 1.240,00$ & RECIFE & 2016 \\
\hline $02019.000529 / 2016-25$ & 7249 & $E$ & Pesca & $12 / 03 / 2016$ & $\mathrm{R} \$ 1.180,00$ & GOIANA & 2016 \\
\hline 02019.000563/2016-08 & 9049477 & $E$ & Pesca & $12 / 03 / 2016$ & $\mathrm{R} \$ 1.122,00$ & $\begin{array}{l}\text { CABO DE SANTO } \\
\text { AGOSTINHO }\end{array}$ & 2016 \\
\hline 02019.000562/2016-55 & 7085 & $E$ & Pesca & $12 / 03 / 2016$ & $\mathrm{R} \$ 1.120,00$ & $\begin{array}{l}\text { CABO DE SANTO } \\
\text { AGOSTINHO }\end{array}$ & 2016 \\
\hline 02019.000536/2016-27 & 9161 & $E$ & Pesca & $15 / 03 / 2016$ & $\mathrm{R} \$ 1.300,00$ & IPOJUCA & 2016 \\
\hline 02019.000624/2016-29 & 7250 & $E$ & Pesca & $15 / 03 / 2016$ & $\mathrm{R} \$ 1.300,00$ & IPOJUCA & 2016 \\
\hline 02019.000537/2016-71 & 9162 & $E$ & Pesca & $15 / 03 / 2016$ & $\mathrm{R} \$ 1.300,00$ & IPOJUCA & 2016 \\
\hline 02019.000538/2016-16 & 9163 & $E$ & Pesca & $15 / 03 / 2016$ & $\mathrm{R} \$ 1.300,00$ & IPOJUCA & 2016 \\
\hline 02019.000625/2016-73 & 7251 & $E$ & Pesca & $15 / 03 / 2016$ & $\mathrm{R} \$ 1.300,00$ & IPOJUCA & 2016 \\
\hline 02019.000556/2016-06 & 9164 & $E$ & Pesca & $15 / 03 / 2016$ & $\mathrm{R} \$ 1.300,00$ & IPOJUCA & 2016 \\
\hline 02019.000539/2016-61 & 9165 & $E$ & Pesca & $15 / 03 / 2016$ & $\mathrm{R} \$ 1.300,00$ & IPOJUCA & 2016 \\
\hline 02019.000534/2016-38 & 9050551 & $E$ & Pesca & $16 / 03 / 2016$ & $\mathrm{R} \$ 22.300,00$ & TAMANDARE & 2016 \\
\hline 02019.000540/2016-95 & 9167 & $E$ & Pesca & $16 / 03 / 2016$ & $\mathrm{R} \$ 22.300,00$ & TAMANDARE & 2016 \\
\hline 02019.000541/2016-30 & 9168 & $E$ & Pesca & $16 / 03 / 2016$ & $\mathrm{R} \$ 22.300,00$ & TAMANDARE & 2016 \\
\hline 02019.000542/2016-84 & 9169 & $E$ & Pesca & $16 / 03 / 2016$ & $\mathrm{R} \$ 22.300,00$ & TAMANDARE & 2016 \\
\hline 02019.000623/2016-84 & 7088 & $E$ & Fauna & $17 / 03 / 2016$ & $\mathrm{R} \$ 88.500,00$ & GRAVATA & 2016 \\
\hline 02019.000621/2016-95 & 7086 & $E$ & Fauna & $17 / 03 / 2016$ & $\mathrm{R} \$ 12.000,00$ & GRAVATA & 2016 \\
\hline 02019.000622/2016-30 & 7087 & $E$ & Fauna & $17 / 03 / 2016$ & $\mathrm{R} \$ 6.000,00$ & GRAVATA & 2016 \\
\hline 02019.000553/2016-64 & 9049480 & $E$ & Fauna & $17 / 03 / 2016$ & $\mathrm{R} \$ 3.000,00$ & GRAVATA & 2016 \\
\hline $02019.000554 / 2016-17$ & 9051603 & $E$ & Fauna & $17 / 03 / 2016$ & $\mathrm{R} \$ 3.000,00$ & GRAVATA & 2016 \\
\hline 02019.000555/2016-53 & 9051610 & $E$ & Fauna & $17 / 03 / 2016$ & $\mathrm{R} \$ 3.000,00$ & GRAVATA & 2016 \\
\hline $02019.000881 / 2016-61$ & 9074179 & $E$ & Fauna & $19 / 03 / 2016$ & $\mathrm{R} \$ 3.000,00$ & TERRA NOVA & 2016 \\
\hline 02019.000882/2016-13 & 9074180 & $E$ & Fauna & $26 / 03 / 2016$ & $\mathrm{R} \$ 2.500,00$ & SERRITA & 2016 \\
\hline 02001.002730/2015-55 & 9061076 & $E$ & Outras & $28 / 03 / 2016$ & $\mathrm{R} \$ 20.100,00$ & SALGUEIRO & 2016 \\
\hline 02019.000833/2016-72 & 9100 & $E$ & Fauna & $02 / 04 / 2016$ & $R \$ 5.000,00$ & $\begin{array}{l}\text { SAO JOSE DA } \\
\text { COROA GRANDE }\end{array}$ & 2016 \\
\hline 02019.000791/2016-70 & 7089 & $E$ & Fauna & $02 / 04 / 2016$ & $\mathrm{R} \$ 1.500,00$ & $\begin{array}{l}\text { SAO JOSE DA } \\
\text { COROA GRANDE }\end{array}$ & 2016 \\
\hline 02019.000794/2016-11 & 9049481 & $E$ & Flora & $02 / 04 / 2016$ & $\mathrm{R} \$ 16.000,00$ & IPOJUCA & 2016 \\
\hline $02019.000803 / 2016-66$ & 9166 & $\mathrm{E}$ & Outras & $02 / 04 / 2016$ & $\mathrm{R} \$ 510.500,00$ & IPOJUCA & 2016 \\
\hline
\end{tabular}




\begin{tabular}{|c|c|c|c|c|c|c|c|}
\hline 02019.000885/2016-49 & 9074183 & $E$ & Fauna & 03/04/2016 & $\mathrm{R} \$ 22.500,00$ & PARNAMIRIM & 2016 \\
\hline 02019.000884/2016-02 & 9074182 & $E$ & Fauna & 03/04/2016 & $\mathrm{R} \$ 3.500,00$ & SERRITA & 2016 \\
\hline 02019.000804/2016-19 & 9170 & $E$ & Pesca & $05 / 04 / 2016$ & $\mathrm{R} \$ 3.160,00$ & RECIFE & 2016 \\
\hline 02019.000832/2016-28 & 9049482 & $E$ & Pesca & 05/04/2016 & $\mathrm{R} \$ 3.160,00$ & RECIFE & 2016 \\
\hline 02019.000823/2016-37 & 9051597 & $E$ & Pesca & 05/04/2016 & $\mathrm{R} \$ 3.160,00$ & RECIFE & 2016 \\
\hline 02019.000800/2016-22 & 9051599 & $E$ & Pesca & 05/04/2016 & $\mathrm{R} \$ 3.160,00$ & RECIFE & 2016 \\
\hline 02019.000793/2016-69 & 9049440 & $E$ & Pesca & 05/04/2016 & $\mathrm{R} \$ 3.160,00$ & RECIFE & 2016 \\
\hline 02019.000796/2016-01 & 9051374 & $E$ & Fauna & $07 / 04 / 2016$ & $\mathrm{R} \$ 19.000,00$ & RECIFE & 2016 \\
\hline $02019.000797 / 2016-47$ & 9051375 & $E$ & Fauna & $07 / 04 / 2016$ & $\mathrm{R} \$ 9.000,00$ & RECIFE & 2016 \\
\hline 02019.000795/2016-58 & 9051337 & $E$ & Fauna & $07 / 04 / 2016$ & $\mathrm{R} \$ 1.500,00$ & RECIFE & 2016 \\
\hline 02019.000798/2016-91 & 9051377 & $E$ & Fauna & $11 / 04 / 2016$ & $\mathrm{R} \$ 573.000,00$ & RECIFE & 2016 \\
\hline 02019.000799/2016-36 & 9051379 & $E$ & Fauna & $11 / 04 / 2016$ & $\mathrm{R} \$ 165.000,00$ & RECIFE & 2016 \\
\hline 02019.000887/2016-38 & 9074186 & $E$ & Fauna & $11 / 04 / 2016$ & $\mathrm{R} \$ 6.000,00$ & BODOCO & 2016 \\
\hline 02019.000886/2016-93 & 9074184 & $E$ & Fauna & $11 / 04 / 2016$ & $\mathrm{R} \$ 4.500,00$ & EXU & 2016 \\
\hline $02019.000802 / 2016-11$ & 9101 & $E$ & Controle ambiental & $12 / 04 / 2016$ & $R \$ 10.000,00$ & RECIFE & 2016 \\
\hline 02019.000834/2016-17 & 9171 & $\mathrm{E}$ & $\begin{array}{l}\text { Cadastro Técnico } \\
\text { Federal }\end{array}$ & $19 / 04 / 2016$ & $\mathrm{R} \$ 1.800,00$ & IGARASSU & 2016 \\
\hline 02019.001205/2016-12 & 9074178 & $E$ & Fauna & $28 / 04 / 2016$ & $\mathrm{R} \$ 11.500,00$ & SERTANIA & 2016 \\
\hline 02019.001206/2016-59 & 9074187 & $E$ & Fauna & $29 / 04 / 2016$ & $\mathrm{R} \$ 5.000,00$ & SERRA TALHADA & 2016 \\
\hline 02019.000874/2016-69 & 8945 & $E$ & Fauna & $02 / 05 / 2016$ & $\mathrm{R} \$ 18.500,00$ & RECIFE & 2016 \\
\hline 02019.001208/2016-48 & 9074189 & $E$ & Flora & $02 / 05 / 2016$ & $\mathrm{R} \$ 35.886,00$ & ARARIPINA & 2016 \\
\hline 02019.001207/2016-01 & 9074188 & $E$ & Flora & $02 / 05 / 2016$ & $\mathrm{R} \$ 8.000,00$ & ARARIPINA & 2016 \\
\hline 02019.001209/2016-92 & 9100966 & $E$ & Flora & $02 / 05 / 2016$ & $\mathrm{R} \$ 2.830,18$ & ARARIPINA & 2016 \\
\hline 02019.001212/2016-14 & 9112971 & $E$ & Fauna & $06 / 05 / 2016$ & $\mathrm{R} \$ 5.000,00$ & ARARIPINA & 2016 \\
\hline 02019.001210/2016-17 & 9100967 & $E$ & Flora & $06 / 05 / 2016$ & $\mathrm{R} \$ 3.735,00$ & ARARIPINA & 2016 \\
\hline 02019.001007/2016-41 & 9051612 & $E$ & Fauna & $11 / 05 / 2016$ & $\mathrm{R} \$ 9.000,00$ & JATAUBA & 2016 \\
\hline 02019.001039/2016-46 & 9051613 & $E$ & Fauna & $11 / 05 / 2016$ & $\mathrm{R} \$ 8.000,00$ & JATAUBA & 2016 \\
\hline 02019.001012/2016-53 & 9086505 & $E$ & Fauna & $11 / 05 / 2016$ & $\mathrm{R} \$ 5.000,00$ & JATAUBA & 2016 \\
\hline 02019.000998/2016-44 & 9049742 & $E$ & $\begin{array}{l}\text { Cadastro Técnico } \\
\text { Federal }\end{array}$ & $12 / 05 / 2016$ & $\mathrm{R} \$ 3.000,00$ & VERTENTES & 2016 \\
\hline 02019.001002/2016-18 & 9050554 & $E$ & Fauna & $12 / 05 / 2016$ & $\mathrm{R} \$ 1.500,00$ & SAO CAITANO & 2016 \\
\hline 02019.001041/2016-15 & 9104 & $E$ & Flora & $12 / 05 / 2016$ & $\mathrm{R} \$ 109.230,00$ & RECIFE & 2016 \\
\hline 02019.001009/2016-30 & 9105 & $E$ & Flora & $12 / 05 / 2016$ & $\mathrm{R} \$ 10.800,00$ & LIMOEIRO & 2016 \\
\hline 02019.001003/2016-62 & 9050555 & $E$ & Flora & $13 / 05 / 2016$ & $\mathrm{R} \$ 2.000,00$ & PESQUEIRA & 2016 \\
\hline 02019.001111/2016-35 & 7107 & $E$ & $\begin{array}{l}\text { Cadastro Técnico } \\
\text { Federal }\end{array}$ & $14 / 05 / 2016$ & $\mathrm{R} \$ 3.500,00$ & RECIFE & 2016 \\
\hline 02019.001112/2016-80 & 7108 & $E$ & $\begin{array}{l}\text { Cadastro Técnico } \\
\text { Federal }\end{array}$ & $15 / 05 / 2016$ & $\mathrm{R} \$ 4.500,00$ & RECIFE & 2016 \\
\hline 02019.001115/2016-13 & 7111 & $E$ & $\begin{array}{l}\text { Cadastro Técnico } \\
\text { Federal }\end{array}$ & $17 / 05 / 2016$ & $\mathrm{R} \$ 4.500,00$ & RECIFE & 2016 \\
\hline 02019.001118/2016-57 & 7114 & $E$ & $\begin{array}{l}\text { Cadastro Técnico } \\
\text { Federal }\end{array}$ & $17 / 05 / 2016$ & $\mathrm{R} \$ 4.500,00$ & RECIFE & 2016 \\
\hline 02019.001121/2016-71 & 7118 & $E$ & $\begin{array}{l}\text { Cadastro Técnico } \\
\text { Federal }\end{array}$ & $17 / 05 / 2016$ & $\mathrm{R} \$ 4.500,00$ & RECIFE & 2016 \\
\hline 02019.001113/2016-24 & 7109 & $E$ & $\begin{array}{l}\text { Cadastro Técnico } \\
\text { Federal }\end{array}$ & $17 / 05 / 2016$ & $\mathrm{R} \$ 3.500,00$ & RECIFE & 2016 \\
\hline 02019.001114/2016-79 & 7110 & $E$ & $\begin{array}{l}\text { Cadastro Técnico } \\
\text { Federal }\end{array}$ & $17 / 05 / 2016$ & $\mathrm{R} \$ 3.500,00$ & RECIFE & 2016 \\
\hline 02019.001116/2016-68 & 7112 & $E$ & $\begin{array}{l}\text { Cadastro Técnico } \\
\text { Federal }\end{array}$ & $17 / 05 / 2016$ & $\mathrm{R} \$ 3.500,00$ & RECIFE & 2016 \\
\hline 02019.001117/2016-11 & 7113 & $E$ & $\begin{array}{l}\text { Cadastro Técnico } \\
\text { Federal }\end{array}$ & $17 / 05 / 2016$ & $\mathrm{R} \$ 3.500,00$ & RECIFE & 2016 \\
\hline 02019.001119/2016-00 & 7115 & $E$ & $\begin{array}{l}\text { Cadastro Técnico } \\
\text { Federal }\end{array}$ & $17 / 05 / 2016$ & $\mathrm{R} \$ 3.500,00$ & RECIFE & 2016 \\
\hline 02019.001120/2016-26 & 7117 & $E$ & $\begin{array}{l}\text { Cadastro Técnico } \\
\text { Federal }\end{array}$ & $17 / 05 / 2016$ & $\mathrm{R} \$ 3.500,00$ & RECIFE & 2016 \\
\hline 02019.001123/2016-60 & 7120 & $E$ & $\begin{array}{l}\text { Cadastro Técnico } \\
\text { Federal }\end{array}$ & $18 / 05 / 2016$ & $\mathrm{R} \$ 3.500,00$ & RECIFE & 2016 \\
\hline 02019.001122/2016-15 & 7119 & $E$ & $\begin{array}{l}\text { Cadastro Técnico } \\
\text { Federal }\end{array}$ & $18 / 05 / 2016$ & $\mathrm{R} \$ 2.500,00$ & RECIFE & 2016 \\
\hline 02019.000991/2016-22 & 9049441 & $E$ & Fauna & $20 / 05 / 2016$ & $\mathrm{R} \$ 3.500,00$ & PALMEIRINA & 2016 \\
\hline 02019.001124/2016-12 & 7122 & $E$ & $\begin{array}{l}\text { Cadastro Técnico } \\
\text { Federal }\end{array}$ & $21 / 05 / 2016$ & $\mathrm{R} \$ 4.500,00$ & RECIFE & 2016 \\
\hline
\end{tabular}




\begin{tabular}{|c|c|c|c|c|c|c|c|}
\hline 02019.001125/2016-59 & 7123 & $E$ & $\begin{array}{l}\text { Cadastro Técnico } \\
\text { Federal }\end{array}$ & $21 / 05 / 2016$ & $\mathrm{R} \$ 3.500,00$ & RECIFE & 2016 \\
\hline 02019.001126/2016-01 & 7124 & $E$ & $\begin{array}{l}\text { Cadastro Técnico } \\
\text { Federal }\end{array}$ & $21 / 05 / 2016$ & $R \$ 3.500,00$ & RECIFE & 2016 \\
\hline 02019.000993/2016-11 & 9049443 & $E$ & Fauna & $21 / 05 / 2016$ & $\mathrm{R} \$ 9.000,00$ & GARANHUNS & 2016 \\
\hline 02019.001000/2016-29 & 9049744 & $\mathrm{E}$ & Fauna & $21 / 05 / 2016$ & $\mathrm{R} \$ 5.000,00$ & GARANHUNS & 2016 \\
\hline $02019.001042 / 2016-60$ & 9107 & $E$ & Fauna & $21 / 05 / 2016$ & $\mathrm{R} \$ 5.000,00$ & GARANHUNS & 2016 \\
\hline 02019.000999/2016-99 & 9049743 & $\mathrm{E}$ & Fauna & $21 / 05 / 2016$ & $\mathrm{R} \$ 4.000,00$ & GARANHUNS & 2016 \\
\hline 02019.001008/2016-95 & 9102 & $E$ & Fauna & $21 / 05 / 2016$ & $\mathrm{R} \$ 2.000,00$ & GARANHUNS & 2016 \\
\hline 02019.001010/2016-64 & 9106 & $\mathrm{E}$ & Fauna & $21 / 05 / 2016$ & $\mathrm{R} \$ 2.000,00$ & GARANHUNS & 2016 \\
\hline 02019.001221/2016-05 & 8948 & $E$ & Fauna & $22 / 05 / 2016$ & $\mathrm{R} \$ 5.500,00$ & ARCOVERDE & 2016 \\
\hline 02019.000989/2016-53 & 8946 & $\mathrm{E}$ & Fauna & $22 / 05 / 2016$ & $\mathrm{R} \$ 5.000,00$ & ARCOVERDE & 2016 \\
\hline 02019.000994/2016-66 & 9049444 & $E$ & Fauna & $22 / 05 / 2016$ & $\mathrm{R} \$ 2.000,00$ & ARCOVERDE & 2016 \\
\hline 02019.001005/2016-51 & 9050563 & E & $\begin{array}{l}\text { Cadastro Técnico } \\
\text { Federal }\end{array}$ & $23 / 05 / 2016$ & $\mathrm{R} \$ 5.000,00$ & SAO BENTO DO UNA & 2016 \\
\hline 02019.000995/2016-19 & 9049445 & $E$ & Fauna & $23 / 05 / 2016$ & $\mathrm{R} \$ 4.000,00$ & AGUAS BELAS & 2016 \\
\hline 02601.000056/2016-96 & 8557 & $\mathrm{E}$ & Flora & $25 / 05 / 2016$ & $\mathrm{R} \$ 25.000,00$ & PETROLINA & 2016 \\
\hline $02601.000055 / 2016-41$ & 8574 & $E$ & Flora & $25 / 05 / 2016$ & $\mathrm{R} \$ 15.000,00$ & PETROLINA & 2016 \\
\hline 02019.001129/2016-37 & 8949 & $\mathrm{E}$ & Fauna & $27 / 05 / 2016$ & $R \$ 2.500,00$ & RECIFE & 2016 \\
\hline 02019.000997/2016-08 & 9049450 & $E$ & Fauna & $28 / 05 / 2016$ & $\mathrm{R} \$ 30.000,00$ & CARUARU & 2016 \\
\hline 02019.001024/2016-88 & 5794 & $\mathrm{E}$ & Fauna & $28 / 05 / 2016$ & $\mathrm{R} \$ 10.000,00$ & CARUARU & 2016 \\
\hline $02019.000992 / 2016-77$ & 9049442 & $E$ & Fauna & $28 / 05 / 2016$ & $R \$ 5.000,00$ & CARUARU & 2016 \\
\hline 02019.001030/2016-35 & 9049746 & $\mathrm{E}$ & Fauna & $28 / 05 / 2016$ & $\mathrm{R} \$ 1.000,00$ & CARUARU & 2016 \\
\hline 02019.001011/2016-17 & 9108 & $E$ & Fauna & $28 / 05 / 2016$ & $\mathrm{R} \$ 1.000,00$ & CARUARU & 2016 \\
\hline 02019.001025/2016-22 & 8950 & $\mathrm{E}$ & Fauna & $28 / 05 / 2016$ & $\mathrm{R} \$ 1.000,00$ & CARUARU & 2016 \\
\hline $02019.001001 / 2016-73$ & 9049747 & $E$ & Fauna & $28 / 05 / 2016$ & $\mathrm{R} \$ 1.000,00$ & CARUARU & 2016 \\
\hline 02019.000996/2016-55 & 9049446 & $\mathrm{E}$ & Fauna & $28 / 05 / 2016$ & $R \$ 1.000,00$ & CARUARU & 2016 \\
\hline $02019.001152 / 2016-21$ & 8952 & $E$ & Fauna & $28 / 05 / 2016$ & $\mathrm{R} \$ 1.000,00$ & CARUARU & 2016 \\
\hline 02019.000990/2016-88 & 8956 & $\mathrm{E}$ & Fauna & $29 / 05 / 2016$ & $\mathrm{R} \$ 1.000,00$ & CARUARU & 2016 \\
\hline 02019.001029/2016-19 & 9049453 & $E$ & Fauna & $30 / 05 / 2016$ & $\mathrm{R} \$ 11.500,00$ & BELO JARDIM & 2016 \\
\hline 02019.001043/2016-12 & 9109 & $\mathrm{E}$ & Fauna & $30 / 05 / 2016$ & $\mathrm{R} \$ 2.000,00$ & BELO JARDIM & 2016 \\
\hline 02019.001036/2016-11 & 9051326 & $E$ & $\begin{array}{l}\text { Cadastro Técnico } \\
\text { Federal }\end{array}$ & $31 / 05 / 2016$ & $\mathrm{R} \$ 4.500,00$ & RECIFE & 2016 \\
\hline 02019.001032/2016-24 & 9050566 & $\mathrm{E}$ & $\begin{array}{l}\text { Cadastro Técnico } \\
\text { Federal }\end{array}$ & $31 / 05 / 2016$ & $R \$ 3.500,00$ & $\begin{array}{l}\text { JABOATAO DOS } \\
\text { GUARARAPES }\end{array}$ & 2016 \\
\hline 02019.001037/2016-57 & 9051382 & $E$ & $\begin{array}{l}\text { Cadastro Técnico } \\
\text { Federal }\end{array}$ & $31 / 05 / 2016$ & $R \$ 3.500,00$ & RECIFE & 2016 \\
\hline $02019.001038 / 2016-00$ & 9051385 & $E$ & $\begin{array}{l}\text { Cadastro Técnico } \\
\text { Federal }\end{array}$ & $31 / 05 / 2016$ & $\mathrm{R} \$ 3.500,00$ & RECIFE & 2016 \\
\hline 02019.001031/2016-80 & 9050565 & $E$ & $\begin{array}{l}\text { Cadastro Técnico } \\
\text { Federal }\end{array}$ & $31 / 05 / 2016$ & $R \$ 2.500,00$ & GOIANA & 2016 \\
\hline $02006.000637 / 2016-47$ & 9058847 & $\mathrm{E}$ & Fauna & 02/06/2016 & $\begin{array}{l}\mathrm{R} \$ \\
1.381 .000,00\end{array}$ & PETROLANDIA & 2016 \\
\hline 02019.001027/2016-11 & 9048817 & $E$ & Flora & 02/06/2016 & $R \$ 7.500,00$ & RECIFE & 2016 \\
\hline 02019.001034/2016-13 & 9051041 & $E$ & $\begin{array}{l}\text { Cadastro Técnico } \\
\text { Federal }\end{array}$ & 03/06/2016 & $\mathrm{R} \$ 4.500,00$ & RECIFE & 2016 \\
\hline 02019.001086/2016-90 & 9049455 & $E$ & Fauna & 03/06/2016 & $\mathrm{R} \$ 6.500,00$ & TAMANDARE & 2016 \\
\hline 02019.001033/2016-79 & 9050568 & $E$ & Fauna & 03/06/2016 & $\mathrm{R} \$ 2.000,00$ & VENTUROSA & 2016 \\
\hline 02019.001035/2016-68 & 9051042 & $E$ & $\begin{array}{l}\text { Cadastro Técnico } \\
\text { Federal }\end{array}$ & 06/06/2016 & $\mathrm{R} \$ 4.500,00$ & RECIFE & 2016 \\
\hline 02019.001103/2016-99 & 9051383 & $\mathrm{E}$ & $\begin{array}{l}\text { Cadastro Técnico } \\
\text { Federal }\end{array}$ & 06/06/2016 & $\mathrm{R} \$ 4.500,00$ & OLINDA & 2016 \\
\hline 02019.001079/2016-98 & 5779 & $E$ & $\begin{array}{l}\text { Cadastro Técnico } \\
\text { Federal }\end{array}$ & 07/06/2016 & $\mathrm{R} \$ 4.500,00$ & PETROLINA & 2016 \\
\hline 02019.001080/2016-12 & 5780 & $E$ & $\begin{array}{l}\text { Cadastro Técnico } \\
\text { Federal }\end{array}$ & 07/06/2016 & $R \$ 3.500,00$ & RECIFE & 2016 \\
\hline 02006.000638/2016-91 & 9058848 & $E$ & Fauna & 07/06/2016 & $R \$ 690.500,00$ & PETROLANDIA & 2016 \\
\hline 02019.001087/2016-34 & 9049456 & $\mathrm{E}$ & Flora & 07/06/2016 & $\mathrm{R} \$ 10.000,00$ & AGUA PRETA & 2016 \\
\hline 02019.001071/2016-21 & 9051044 & $E$ & $\begin{array}{l}\text { Cadastro Técnico } \\
\text { Federal }\end{array}$ & 08/06/2016 & $\mathrm{R} \$ 6.000,00$ & OLINDA & 2016 \\
\hline 02019.001097/2016-70 & 9051327 & E & $\begin{array}{l}\text { Cadastro Técnico } \\
\text { Federal }\end{array}$ & 08/06/2016 & $\mathrm{R} \$ 6.000,00$ & OLINDA & 2016 \\
\hline
\end{tabular}




\begin{tabular}{|c|c|c|c|c|c|c|c|}
\hline 02019.001081/2016-67 & 5781 & $E$ & $\begin{array}{l}\text { Cadastro Técnico } \\
\text { Federal }\end{array}$ & 08/06/2016 & $\mathrm{R} \$ 4.500,00$ & RECIFE & 2016 \\
\hline 02019.001070/2016-87 & 9051043 & $E$ & $\begin{array}{l}\text { Cadastro Técnico } \\
\text { Federal }\end{array}$ & 08/06/2016 & $\mathrm{R} \$ 4.500,00$ & OLINDA & 2016 \\
\hline 02019.001083/2016-56 & 5783 & $E$ & $\begin{array}{l}\text { Cadastro Técnico } \\
\text { Federal }\end{array}$ & 08/06/2016 & $\mathrm{R} \$ 4.500,00$ & RECIFE & 2016 \\
\hline 02019.001084/2016-09 & 5784 & $E$ & $\begin{array}{l}\text { Cadastro Técnico } \\
\text { Federal }\end{array}$ & 08/06/2016 & $\mathrm{R} \$ 4.500,00$ & ARARIPINA & 2016 \\
\hline 02019.001082/2016-10 & 5782 & $E$ & $\begin{array}{l}\text { Cadastro Técnico } \\
\text { Federal }\end{array}$ & 08/06/2016 & $\mathrm{R} \$ 3.500,00$ & RECIFE & 2016 \\
\hline 02019.001098/2016-14 & 9051329 & $E$ & $\begin{array}{l}\text { Cadastro Técnico } \\
\text { Federal }\end{array}$ & 08/06/2016 & $\mathrm{R} \$ 3.500,00$ & RECIFE & 2016 \\
\hline 02019.001093/2016-91 & 9051048 & $E$ & $\begin{array}{l}\text { Cadastro Técnico } \\
\text { Federal }\end{array}$ & 09/06/2016 & $\mathrm{R} \$ 6.000,00$ & RECIFE & 2016 \\
\hline 02019.001095/2016-81 & 9051050 & $E$ & $\begin{array}{l}\text { Cadastro Técnico } \\
\text { Federal }\end{array}$ & 09/06/2016 & $\mathrm{R} \$ 6.000,00$ & RECIFE & 2016 \\
\hline 02019.001102/2016-44 & 9051336 & $E$ & $\begin{array}{l}\text { Cadastro Técnico } \\
\text { Federal }\end{array}$ & 09/06/2016 & $\mathrm{R} \$ 6.000,00$ & $\begin{array}{l}\text { CABO DE SANTO } \\
\text { AGOSTINHO }\end{array}$ & 2016 \\
\hline 02019.001092/2016-47 & 9051047 & $E$ & $\begin{array}{l}\text { Cadastro Técnico } \\
\text { Federal }\end{array}$ & 09/06/2016 & $\mathrm{R} \$ 4.500,00$ & RECIFE & 2016 \\
\hline 02019.001101/2016-08 & 9051335 & $E$ & $\begin{array}{l}\text { Cadastro Técnico } \\
\text { Federal }\end{array}$ & 09/06/2016 & $\mathrm{R} \$ 4.500,00$ & $\begin{array}{l}\text { CABO DE SANTO } \\
\text { AGOSTINHO }\end{array}$ & 2016 \\
\hline 02019.001094/2016-36 & 9051049 & $E$ & $\begin{array}{l}\text { Cadastro Técnico } \\
\text { Federal }\end{array}$ & 09/06/2016 & $\mathrm{R} \$ 4.000,00$ & RECIFE & 2016 \\
\hline 02019.001096/2016-25 & 9051051 & $E$ & $\begin{array}{l}\text { Cadastro Técnico } \\
\text { Federal }\end{array}$ & 09/06/2016 & $\mathrm{R} \$ 4.000,00$ & RECIFE & 2016 \\
\hline 02019.001085/2016-45 & 5785 & $E$ & $\begin{array}{l}\text { Cadastro Técnico } \\
\text { Federal }\end{array}$ & 09/06/2016 & $\mathrm{R} \$ 3.500,00$ & CARUARU & 2016 \\
\hline 02019.001099/2016-69 & 9051333 & $E$ & $\begin{array}{l}\text { Cadastro Técnico } \\
\text { Federal }\end{array}$ & 09/06/2016 & $\mathrm{R} \$ 2.500,00$ & $\begin{array}{l}\text { JABOATAO DOS } \\
\text { GUARARAPES }\end{array}$ & 2016 \\
\hline 02019.001100/2016-55 & 9051334 & $E$ & $\begin{array}{l}\text { Cadastro Técnico } \\
\text { Federal }\end{array}$ & 09/06/2016 & $\mathrm{R} \$ 2.000,00$ & $\begin{array}{l}\text { JABOATAO DOS } \\
\text { GUARARAPES }\end{array}$ & 2016 \\
\hline 02019.001088/2016-89 & 9049457 & $E$ & Fauna & 09/06/2016 & $\mathrm{R} \$ 3.000,00$ & ESCADA & 2016 \\
\hline 02019.001211/2016-61 & 9100968 & $\mathrm{E}$ & Flora & $14 / 06 / 2016$ & $\mathrm{R} \$ 10.000,00$ & ARARIPINA & 2016 \\
\hline 02019.001153/2016-76 & 9741 & $E$ & $\begin{array}{l}\text { Cadastro Técnico } \\
\text { Federal }\end{array}$ & 29/06/2016 & $\mathrm{R} \$ 5.000,00$ & RECIFE & 2016 \\
\hline 02019.001158/2016-07 & 9759 & $E$ & $\begin{array}{l}\text { Cadastro Técnico } \\
\text { Federal }\end{array}$ & 01/07/2016 & $\mathrm{R} \$ 5.500,00$ & RECIFE & 2016 \\
\hline 02019.001154/2016-11 & 9754 & $E$ & $\begin{array}{l}\text { Cadastro Técnico } \\
\text { Federal }\end{array}$ & 01/07/2016 & $\mathrm{R} \$ 5.000,00$ & RECIFE & 2016 \\
\hline 02019.001155/2016-65 & 9755 & $E$ & $\begin{array}{l}\text { Cadastro Técnico } \\
\text { Federal }\end{array}$ & 01/07/2016 & $\mathrm{R} \$ 5.000,00$ & RECIFE & 2016 \\
\hline 02019.001156/2016-18 & 9757 & $E$ & $\begin{array}{l}\text { Cadastro Técnico } \\
\text { Federal }\end{array}$ & 01/07/2016 & $\mathrm{R} \$ 5.000,00$ & RECIFE & 2016 \\
\hline 02019.001157/2016-54 & 9758 & $E$ & $\begin{array}{l}\text { Cadastro Técnico } \\
\text { Federal }\end{array}$ & 01/07/2016 & $\mathrm{R} \$ 5.000,00$ & RECIFE & 2016 \\
\hline 02020.000298/2016-11 & 9058354 & $E$ & $\begin{array}{l}\text { Cadastro Técnico } \\
\text { Federal }\end{array}$ & 07/07/2016 & $\mathrm{R} \$ 500,00$ & ARARIPINA & 2016 \\
\hline 02019.001186/2016-16 & 9760 & $E$ & Flora & $14 / 07 / 2016$ & $\mathrm{R} \$ 5.000,00$ & IPOJUCA & 2016 \\
\hline 02019.001213/2016-51 & 9761 & $E$ & Fauna & 19/07/2016 & $\mathrm{R} \$ 10.000,00$ & RECIFE & 2016 \\
\hline 02019.001214/2016-03 & 9762 & $\mathrm{E}$ & Flora & 19/07/2016 & $\mathrm{R} \$ 1.500,00$ & RECIFE & 2016 \\
\hline 02016.001368/2016-17 & 9089668 & $E$ & Pesca & $21 / 07 / 2016$ & $\mathrm{R} \$ 1.500,00$ & RECIFE & 2016 \\
\hline 02019.001330/2016-14 & 9765 & $E$ & $\begin{array}{l}\text { Cadastro Técnico } \\
\text { Federal }\end{array}$ & 09/08/2016 & $\mathrm{R} \$ 6.000,00$ & RECIFE & 2016 \\
\hline 02019.001329/2016-90 & 9764 & $E$ & $\begin{array}{l}\text { Cadastro Técnico } \\
\text { Federal }\end{array}$ & 09/08/2016 & $\mathrm{R} \$ 3.500,00$ & RECIFE & 2016 \\
\hline 02019.001331/2016-69 & 9766 & $E$ & $\begin{array}{l}\text { Cadastro Técnico } \\
\text { Federal }\end{array}$ & 09/08/2016 & $\mathrm{R} \$ 1.800,00$ & RECIFE & 2016 \\
\hline 02019.001272/2016-29 & 5786 & $E$ & $\begin{array}{l}\text { Cadastro Técnico } \\
\text { Federal }\end{array}$ & $10 / 08 / 2016$ & $\mathrm{R} \$ 2.000,00$ & $\begin{array}{l}\text { JABOATAO DOS } \\
\text { GUARARAPES }\end{array}$ & 2016 \\
\hline 02019.001259/2016-70 & 9051045 & $\mathrm{E}$ & $\begin{array}{l}\text { Cadastro Técnico } \\
\text { Federal }\end{array}$ & $10 / 08 / 2016$ & $\mathrm{R} \$ 2.000,00$ & ARACOIABA & 2016 \\
\hline 02019.001273/2016-73 & 5787 & $E$ & $\begin{array}{l}\text { Cadastro Técnico } \\
\text { Federal }\end{array}$ & $10 / 08 / 2016$ & $\mathrm{R} \$ 2.000,00$ & $\begin{array}{l}\text { JABOATAO DOS } \\
\text { GUARARAPES }\end{array}$ & 2016 \\
\hline 02019.001260/2016-02 & 9051046 & $E$ & $\begin{array}{l}\text { Cadastro Técnico } \\
\text { Federal }\end{array}$ & $10 / 08 / 2016$ & $\mathrm{R} \$ 2.000,00$ & ABREU E LIMA & 2016 \\
\hline
\end{tabular}




\begin{tabular}{|c|c|c|c|c|c|c|c|}
\hline 02019.001316/2016-11 & 9767 & $E$ & Outras & $10 / 08 / 2016$ & $\mathrm{R} \$ 4.000,00$ & RECIFE & 2016 \\
\hline 02019.001258/2016-25 & 7272 & $E$ & Pesca & $10 / 08 / 2016$ & $\mathrm{R} \$ 1.280,00$ & RECIFE & 2016 \\
\hline 02019.001313/2016-87 & 5788 & $E$ & $\begin{array}{l}\text { Cadastro Técnico } \\
\text { Federal }\end{array}$ & $11 / 08 / 2016$ & $\mathrm{R} \$ 2.000,00$ & MORENO & 2016 \\
\hline 02019.001314/2016-21 & 7273 & $E$ & Flora & $11 / 08 / 2016$ & $\mathrm{R} \$ 10.000,00$ & RECIFE & 2016 \\
\hline 02019.001274/2016-18 & 9089779 & $E$ & Outras & $11 / 08 / 2016$ & $\mathrm{R} \$ 4.000,00$ & $\begin{array}{l}\text { CABO DE SANTO } \\
\text { AGOSTINHO }\end{array}$ & 2016 \\
\hline 02019.001323/2016-12 & 9051328 & $E$ & $\begin{array}{l}\text { Cadastro Técnico } \\
\text { Federal }\end{array}$ & $15 / 08 / 2016$ & $\mathrm{R} \$ 3.600,00$ & RECIFE & 2016 \\
\hline 02019.001324/2016-67 & 9051330 & $E$ & $\begin{array}{l}\text { Cadastro Técnico } \\
\text { Federal }\end{array}$ & $15 / 08 / 2016$ & $\mathrm{R} \$ 3.500,00$ & RECIFE & 2016 \\
\hline 02019.001325/2016-10 & 9180 & $E$ & Flora & $18 / 08 / 2016$ & $\mathrm{R} \$ 10.000,00$ & OURICURI & 2016 \\
\hline 02019.001326/2016-56 & 9192 & $E$ & Pesca & 19/08/2016 & $\mathrm{R} \$ 1.320,00$ & IPOJUCA & 2016 \\
\hline 02019.001327/2016-09 & 9193 & $E$ & Pesca & 19/08/2016 & $\mathrm{R} \$ 1.320,00$ & IPOJUCA & 2016 \\
\hline 02019.001425/2016-38 & 9051332 & $E$ & $\begin{array}{l}\text { Cadastro Técnico } \\
\text { Federal }\end{array}$ & $25 / 08 / 2016$ & $\mathrm{R} \$ 10.500,00$ & RECIFE & 2016 \\
\hline 02019.001424/2016-93 & 9051331 & $E$ & $\begin{array}{l}\text { Cadastro Técnico } \\
\text { Federal }\end{array}$ & $25 / 08 / 2016$ & $\mathrm{R} \$ 6.000,00$ & RECIFE & 2016 \\
\hline 02019.001445/2016-17 & 9051339 & $E$ & $\begin{array}{l}\text { Cadastro Técnico } \\
\text { Federal }\end{array}$ & $25 / 08 / 2016$ & $\mathrm{R} \$ 1.200,00$ & RECIFE & 2016 \\
\hline 02019.001172/2016-01 & 9049483 & $E$ & Flora & $25 / 08 / 2016$ & $\mathrm{R} \$ 8.100,00$ & PARNAMIRIM & 2016 \\
\hline 02019.001423/2016-49 & 9049748 & $E$ & Outras & 12/09/2016 & $\mathrm{R} \$ 414,47$ & IPUBI & 2016 \\
\hline 02001.004777/2016-34 & 9113384 & $E$ & Outras & 22/09/2016 & $\mathrm{R} \$ 722.500,00$ & $\begin{array}{l}\text { CABO DE SANTO } \\
\text { AGOSTINHO }\end{array}$ & 2016 \\
\hline 02019.001498/2016-20 & 5791 & $E$ & Flora & $28 / 09 / 2016$ & $\mathrm{R} \$ 20.000,00$ & RECIFE & 2016 \\
\hline 02019.001499/2016-74 & 5792 & $E$ & Flora & 28/09/2016 & $\mathrm{R} \$ 4.000,00$ & RECIFE & 2016 \\
\hline 02019.001500/2016-61 & 7274 & $E$ & $\begin{array}{l}\text { Cadastro Técnico } \\
\text { Federal }\end{array}$ & 29/09/2016 & $\mathrm{R} \$ 6.500,00$ & $\begin{array}{l}\text { CABO DE SANTO } \\
\text { AGOSTINHO }\end{array}$ & 2016 \\
\hline 02019.001507/2016-82 & 9051635 & $E$ & $\begin{array}{l}\text { Cadastro Técnico } \\
\text { Federal }\end{array}$ & 29/09/2016 & $\mathrm{R} \$ 6.500,00$ & RECIFE & 2016 \\
\hline 02019.001506/2016-38 & 9049499 & $E$ & Outras & 29/09/2016 & $\mathrm{R} \$ 5.000,00$ & JATOBA & 2016 \\
\hline 02019.001509/2016-71 & 9092660 & E & $\begin{array}{l}\text { Cadastro Técnico } \\
\text { Federal }\end{array}$ & 30/09/2016 & $\mathrm{R} \$ 6.500,00$ & RECIFE & 2016 \\
\hline 02019.001501/2016-13 & 7275 & $E$ & $\begin{array}{l}\text { Cadastro Técnico } \\
\text { Federal }\end{array}$ & $30 / 09 / 2016$ & $\mathrm{R} \$ 3.900,00$ & TIMBAUBA & 2016 \\
\hline 02019.001530/2016-77 & 9092661 & $E$ & Flora & 06/10/2016 & $\mathrm{R} \$ 1.800,00$ & RECIFE & 2016 \\
\hline 02019.001526/2016-17 & 9092662 & $E$ & Flora & 06/10/2016 & $\mathrm{R} \$ 1.800,00$ & RECIFE & 2016 \\
\hline 02019.001527/2016-53 & 9092663 & $E$ & Flora & 10/10/2016 & $\mathrm{R} \$ 1.800,00$ & RECIFE & 2016 \\
\hline 02019.001543/2016-46 & 5793 & $\mathrm{E}$ & $\begin{array}{l}\text { Cadastro Técnico } \\
\text { Federal }\end{array}$ & $25 / 10 / 2016$ & $\mathrm{R} \$ 4.500,00$ & RECIFE & 2016 \\
\hline 02019.001536/2016-44 & 9049485 & E & Outras & 26/10/2016 & $\mathrm{R} \$ 20.500,00$ & $\begin{array}{l}\text { CABO DE SANTO } \\
\text { AGOSTINHO }\end{array}$ & 2016 \\
\hline 02019.001546/2016-80 & 5796 & E & $\begin{array}{l}\text { Cadastro Técnico } \\
\text { Federal }\end{array}$ & $27 / 10 / 2016$ & $\mathrm{R} \$ 3.500,00$ & RECIFE & 2016 \\
\hline 02009.000988/2016-28 & 9115217 & $E$ & Fauna & 27/10/2016 & $\mathrm{R} \$ 18.500,00$ & BEZERROS & 2016 \\
\hline $02016.001755 / 2016-53$ & 4885 & $E$ & Fauna & $27 / 10 / 2016$ & $\mathrm{R} \$ 17.000,00$ & BEZERROS & 2016 \\
\hline 02009.000990/2016-05 & 9115219 & $E$ & Fauna & 27/10/2016 & $\mathrm{R} \$ 11.000,00$ & BEZERROS & 2016 \\
\hline 02009.000987/2016-83 & 9115216 & $E$ & Fauna & 27/10/2016 & $\mathrm{R} \$ 10.000,00$ & BEZERROS & 2016 \\
\hline 02009.000989/2016-72 & 9115218 & $E$ & Fauna & 27/10/2016 & $\mathrm{R} \$ 5.600,00$ & BEZERROS & 2016 \\
\hline 02001.007018/2016-23 & 1161 & $E$ & Fauna & $27 / 10 / 2016$ & $\mathrm{R} \$ 5.600,00$ & BEZERROS & 2016 \\
\hline 02001.006927/2016-44 & 9107530 & $E$ & Fauna & 27/10/2016 & $\mathrm{R} \$ 4.000,00$ & BEZERROS & 2016 \\
\hline $02016.000081 / 2017-51$ & 9101655 & $E$ & Fauna & $27 / 10 / 2016$ & $\mathrm{R} \$ 2.000,00$ & BEZERROS & 2016 \\
\hline 02001.007011/2016-10 & 1162 & $E$ & Fauna & 27/10/2016 & $\mathrm{R} \$ 500,00$ & BEZERROS & 2016 \\
\hline 02019.001562/2016-72 & 9194 & $E$ & Outras & 27/10/2016 & $\mathrm{R} \$ 1.000,00$ & $\begin{array}{l}\text { JABOATAO DOS } \\
\text { GUARARAPES }\end{array}$ & 2016 \\
\hline 02019.001563/2016-17 & 9195 & $E$ & Outras & 27/10/2016 & $\mathrm{R} \$ 500,00$ & $\begin{array}{l}\text { JABOATAO DOS } \\
\text { GUARARAPES }\end{array}$ & 2016 \\
\hline 02019.001551/2016-92 & 9092664 & $E$ & Outras & $30 / 10 / 2016$ & $\mathrm{R} \$ 2.000,00$ & SALGUEIRO & 2016 \\
\hline 02009.000995/2016-20 & 9115224 & $E$ & Fauna & $31 / 10 / 2016$ & $\mathrm{R} \$ 7.500,00$ & PARANATAMA & 2016 \\
\hline 02019.001560/2016-83 & 9096069 & $E$ & Outras & $31 / 10 / 2016$ & $\mathrm{R} \$ 3.500,00$ & RECIFE & 2016 \\
\hline 02019.001561/2016-28 & 9197 & $E$ & Outras & $01 / 11 / 2016$ & $\mathrm{R} \$ 3.500,00$ & $\begin{array}{l}\text { JABOATAO DOS } \\
\text { GUARARAPES }\end{array}$ & 2016 \\
\hline 02019.001565/2016-14 & 5795 & $E$ & Flora & $07 / 11 / 2016$ & $\mathrm{R} \$ 10.000,00$ & VERDEJANTE & 2016 \\
\hline
\end{tabular}




\begin{tabular}{|c|c|c|c|c|c|c|c|}
\hline 02019.001586/2016-21 & 5798 & $E$ & Flora & 09/11/2016 & $\mathrm{R} \$ 2.000,00$ & PESQUEIRA & 2016 \\
\hline 02019.001592/2016-89 & 5799 & $\mathrm{E}$ & Flora & 09/11/2016 & $\mathrm{R} \$ 1.200,00$ & PESQUEIRA & 2016 \\
\hline 02019.001569/2016-94 & 9096068 & $E$ & $\begin{array}{l}\text { Cadastro Técnico } \\
\text { Federal }\end{array}$ & $10 / 11 / 2016$ & $\mathrm{R} \$ 4.500,00$ & PETROLINA & 2016 \\
\hline 02019.001568/2016-40 & 9093480 & $E$ & $\begin{array}{l}\text { Cadastro Técnico } \\
\text { Federal }\end{array}$ & $10 / 11 / 2016$ & $\mathrm{R} \$ 3.500,00$ & RECIFE & 2016 \\
\hline $02019.001644 / 2016-17$ & 9051638 & $E$ & Flora & $10 / 11 / 2016$ & $\mathrm{R} \$ 10.000,00$ & IPOJUCA & 2016 \\
\hline 02019.001656/2016-41 & 9198 & $E$ & Flora & $10 / 11 / 2016$ & $\mathrm{R} \$ 5.000,00$ & IPOJUCA & 2016 \\
\hline 02019.001583/2016-98 & 5800 & $E$ & Fauna & $12 / 11 / 2016$ & $\mathrm{R} \$ 3.500,00$ & GARANHUNS & 2016 \\
\hline 02019.001591/2016-34 & 9051639 & $E$ & Pesca & $12 / 11 / 2016$ & $\mathrm{R} \$ 5.000,00$ & SIRINHAEM & 2016 \\
\hline 02019.001587/2016-76 & 9199 & $E$ & Fauna & $18 / 11 / 2016$ & $R \$ 500,00$ & $\begin{array}{l}\text { JABOATAO DOS } \\
\text { GUARARAPES }\end{array}$ & 2016 \\
\hline $02019.001649 / 2016-40$ & 9049487 & $E$ & Fauna & $22 / 11 / 2016$ & $\mathrm{R} \$ 11.500,00$ & SURUBIM & 2016 \\
\hline 02019.001660/2016-18 & 5797 & $E$ & Fauna & $22 / 11 / 2016$ & $\mathrm{R} \$ 3.500,00$ & SURUBIM & 2016 \\
\hline 02601.100012/2017-46 & 9045491 & $E$ & $\begin{array}{l}\text { Cadastro Técnico } \\
\text { Federal }\end{array}$ & $25 / 11 / 2016$ & $\mathrm{R} \$ 1.800,00$ & JATOBA & 2016 \\
\hline 02019.001732/2016-19 & 9096070 & $E$ & Fauna & $28 / 11 / 2016$ & $\mathrm{R} \$ 8.500,00$ & BUIQUE & 2016 \\
\hline 02019.001733/2016-63 & 9096072 & $E$ & Fauna & $28 / 11 / 2016$ & $\mathrm{R} \$ 5.000,00$ & BUIQUE & 2016 \\
\hline 02019.001734/2016-16 & 9096075 & $E$ & Fauna & 29/11/2016 & $\mathrm{R} \$ 7.000,00$ & IBIMIRIM & 2016 \\
\hline 02019.001665/2016-32 & 9051640 & $E$ & $\begin{array}{l}\text { Cadastro Técnico } \\
\text { Federal }\end{array}$ & $30 / 11 / 2016$ & $\mathrm{R} \$ 7.200,00$ & RECIFE & 2016 \\
\hline 02019.001666/2016-87 & 9051641 & $E$ & $\begin{array}{l}\text { Cadastro Técnico } \\
\text { Federal }\end{array}$ & $30 / 11 / 2016$ & $\mathrm{R} \$ 3.500,00$ & RECIFE & 2016 \\
\hline 02019.001667/2016-21 & 9051642 & $E$ & $\begin{array}{l}\text { Cadastro Técnico } \\
\text { Federal }\end{array}$ & $30 / 11 / 2016$ & $\mathrm{R} \$ 3.500,00$ & RECIFE & 2016 \\
\hline 02601.100036/2017-03 & 9045493 & $\mathrm{E}$ & $\begin{array}{l}\text { Cadastro Técnico } \\
\text { Federal }\end{array}$ & $30 / 11 / 2016$ & $\mathrm{R} \$ 2.000,00$ & PETROLANDIA & 2016 \\
\hline 02019.001668/2016-76 & 9051643 & $E$ & $\begin{array}{l}\text { Cadastro Técnico } \\
\text { Federal }\end{array}$ & $30 / 11 / 2016$ & $\mathrm{R} \$ 1.200,00$ & RECIFE & 2016 \\
\hline $02601.000002 / 2017-10$ & 9112981 & $E$ & Fauna & $21 / 12 / 2016$ & $\mathrm{R} \$ 1.000,00$ & PETROLINA & 2016 \\
\hline \multirow[t]{3}{*}{$02601.000001 / 2017-67$} & 9112972 & $E$ & Fauna & $21 / 12 / 2016$ & $\mathrm{R} \$ 500,00$ & PETROLINA & 2016 \\
\hline & 9051644 & $E$ & $\begin{array}{l}\text { Cadastro Técnico } \\
\text { Federal }\end{array}$ & 03/01/2017 & $\mathrm{R} \$ 3.600,00$ & CAMUTANGA & 2017 \\
\hline & 9049755 & $E$ & Controle ambiental & $12 / 01 / 2017$ & $\mathrm{R} \$ 300.000,00$ & OLINDA & 2017 \\
\hline 02019.000131/2017-70 & 9089771 & $E$ & Flora & $20 / 01 / 2017$ & $R \$ 20.000,00$ & CUSTODIA & 2017 \\
\hline 02019.000132/2017-14 & 5803 & $E$ & Pesca & $21 / 01 / 2017$ & $\mathrm{R} \$ 700,00$ & PETROLINA & 2017 \\
\hline 02019.000229/2017-27 & 9049758 & $E$ & Pesca & $21 / 01 / 2017$ & $\mathrm{R} \$ 700,00$ & PETROLINA & 2017 \\
\hline 02019.000113/2017-98 & 5804 & $E$ & Pesca & $22 / 01 / 2017$ & $\mathrm{R} \$ 770,00$ & PETROLINA & 2017 \\
\hline 02019.000115/2017-87 & 9049760 & $E$ & Pesca & $22 / 01 / 2017$ & $\mathrm{R} \$ 700,00$ & PETROLINA & 2017 \\
\hline $02019.000166 / 2017-17$ & 9051342 & $E$ & Pesca & $27 / 01 / 2017$ & $\mathrm{R} \$ 800,00$ & PETROLANDIA & 2017 \\
\hline 02019.000168/2017-06 & 9051646 & $E$ & Flora & $31 / 01 / 2017$ & $\mathrm{R} \$ 1.800,00$ & ARARIPINA & 2017 \\
\hline 02019.000172/2017-66 & 9051645 & $E$ & $\begin{array}{l}\text { Org. Gen. Modific. e } \\
\text { Biopirataria }\end{array}$ & $31 / 01 / 2017$ & $\mathrm{R} \$ 10.000,00$ & ARARIPINA & 2017 \\
\hline 02019.000144/2017-49 & 9051648 & $E$ & Fauna & $01 / 02 / 2017$ & $\mathrm{R} \$ 205.000,00$ & SALGUEIRO & 2017 \\
\hline $02019.000163 / 2017-75$ & 9051649 & $E$ & Fauna & $01 / 02 / 2017$ & $\mathrm{R} \$ 205.000,00$ & SALGUEIRO & 2017 \\
\hline 02019.000171/2017-11 & 9051650 & $E$ & $\begin{array}{l}\text { Org. Gen. Modific. e } \\
\text { Biopirataria }\end{array}$ & $01 / 02 / 2017$ & $\mathrm{R} \$ 9.018,00$ & IPUBI & 2017 \\
\hline 02019.000170/2017-77 & 9051651 & $E$ & $\begin{array}{l}\text { Org. Gen. Modific. e } \\
\text { Biopirataria }\end{array}$ & $01 / 02 / 2017$ & $\mathrm{R} \$ 9.018,00$ & IPUBI & 2017 \\
\hline $02019.000230 / 2017-51$ & 9051654 & $E$ & Flora & $02 / 02 / 2017$ & $\mathrm{R} \$ 1.800,00$ & PARNAMIRIM & 2017 \\
\hline $02019.000167 / 2017-53$ & 9051652 & $E$ & Flora & $02 / 02 / 2017$ & $\mathrm{R} \$-$ & PARNAMIRIM & 2017 \\
\hline 02019.000146/2017-38 & 9089687 & $E$ & Pesca & $02 / 02 / 2017$ & $\mathrm{R} \$ 1.040,00$ & $\begin{array}{l}\text { CABO DE SANTO } \\
\text { AGOSTINHO }\end{array}$ & 2017 \\
\hline $02019.000145 / 2017-93$ & 9089688 & $E$ & Pesca & $02 / 02 / 2017$ & $\mathrm{R} \$ 760,00$ & IPOJUCA & 2017 \\
\hline $02019.000231 / 2017-04$ & 9051655 & $E$ & Fauna & 03/02/2017 & $\mathrm{R} \$ 5.000,00$ & PETROLINA & 2017 \\
\hline 02019.000169/2017-42 & 9051657 & $E$ & Fauna & $03 / 02 / 2017$ & $\mathrm{R} \$ 1.000,00$ & PETROLINA & 2017 \\
\hline \multirow[t]{2}{*}{ 02019.000226/2017-93 } & 9049497 & $E$ & Pesca & $09 / 02 / 2017$ & $\mathrm{R} \$ 700,00$ & $\begin{array}{l}\text { JABOATAO DOS } \\
\text { GUARARAPES }\end{array}$ & 2017 \\
\hline & 9049764 & $E$ & Pesca & $10 / 02 / 2017$ & $\mathrm{R} \$ 5.840,00$ & IPOJUCA & 2017 \\
\hline 02019.000209/2017-56 & 9200 & $\mathrm{E}$ & Pesca & $11 / 02 / 2017$ & $\mathrm{R} \$ 3.260,00$ & $\begin{array}{l}\text { CABO DE SANTO } \\
\text { AGOSTINHO }\end{array}$ & 2017 \\
\hline 02019.000222/2017-13 & 9204 & $E$ & Fauna & $12 / 02 / 2017$ & $\mathrm{R} \$ 3.000,00$ & SIRINHAEM & 2017 \\
\hline 02019.000207/2017-67 & 9089686 & $E$ & Fauna & $12 / 02 / 2017$ & $\mathrm{R} \$ 2.000,00$ & SIRINHAEM & 2017 \\
\hline
\end{tabular}




\begin{tabular}{|c|c|c|c|c|c|c|c|}
\hline 02019.000220/2017-16 & 9201 & $E$ & Fauna & $12 / 02 / 2017$ & $R \$ 500,00$ & SIRINHAEM & 2017 \\
\hline 02019.001505/2016-93 & 9049498 & $E$ & Fauna & $12 / 02 / 2017$ & $\mathrm{R} \$ 500,00$ & SIRINHAEM & 2017 \\
\hline 02019.000202/2017-34 & 9049765 & $E$ & Fauna & $12 / 02 / 2017$ & $\mathrm{R} \$ 500,00$ & SIRINHAEM & 2017 \\
\hline 02019.000221/2017-61 & 9202 & $E$ & Fauna & $12 / 02 / 2017$ & $\mathrm{R} \$ 500,00$ & SIRINHAEM & 2017 \\
\hline 02019.000203/2017-89 & 9049766 & $E$ & Fauna & $12 / 02 / 2017$ & $\mathrm{R} \$ 500,00$ & SIRINHAEM & 2017 \\
\hline 02019.000206/2017-12 & 9051653 & $E$ & Fauna & $12 / 02 / 2017$ & $\mathrm{R} \$ 500,00$ & SIRINHAEM & 2017 \\
\hline 02019.000223/2017-50 & 9205 & $E$ & Pesca & $13 / 02 / 2017$ & $R \$ 920,00$ & TAMANDARE & 2017 \\
\hline $02019.000204 / 2017-23$ & 9049767 & $\mathrm{E}$ & Pesca & $13 / 02 / 2017$ & $\mathrm{R} \$ 820,00$ & TAMANDARE & 2017 \\
\hline 02019.000268/2017-24 & 9051349 & $E$ & Fauna & $15 / 02 / 2017$ & $\mathrm{R} \$ 58.000,00$ & RECIFE & 2017 \\
\hline $02019.000205 / 2017-78$ & 9051351 & $\mathrm{E}$ & Fauna & $15 / 02 / 2017$ & $\mathrm{R} \$ 6.000,00$ & RECIFE & 2017 \\
\hline 02019.000208/2017-10 & 9089691 & $E$ & Pesca & $15 / 02 / 2017$ & $\mathrm{R} \$ 12.060,00$ & ILHA DE ITAMARACA & 2017 \\
\hline 02019.000201/2017-90 & 9049500 & $E$ & Pesca & $15 / 02 / 2017$ & $\mathrm{R} \$ 11.780,00$ & ILHA DE ITAMARACA & 2017 \\
\hline 02019.000217/2017-01 & 9051658 & $E$ & Pesca & $15 / 02 / 2017$ & $\mathrm{R} \$ 1.180,00$ & GOIANA & 2017 \\
\hline 02019.000218/2017-47 & 9096153 & $E$ & $\begin{array}{l}\text { Cadastro Técnico } \\
\text { Federal }\end{array}$ & $21 / 02 / 2017$ & $\mathrm{R} \$ 3.500,00$ & CONDADO & 2017 \\
\hline \multirow[t]{2}{*}{ 02019.000228/2017-82 } & 9049501 & $E$ & $\begin{array}{l}\text { Cadastro Técnico } \\
\text { Federal }\end{array}$ & $21 / 02 / 2017$ & $\mathrm{R} \$ 1.200,00$ & CONDADO & 2017 \\
\hline & 9096169 & $E$ & $\begin{array}{l}\text { Cadastro Técnico } \\
\text { Federal }\end{array}$ & 23/02/2017 & $\mathrm{R} \$ 3.500,00$ & RECIFE & 2017 \\
\hline 02001.101328/2017-14 & 9125138 & $E$ & Outras & 09/03/2017 & $\mathrm{R} \$ 207.256,00$ & RECIFE & 2017 \\
\hline 02001.001130/2017-31 & 9046411 & $E$ & Outras & 09/03/2017 & $\mathrm{R} \$ 11.000,00$ & JOAQUIM NABUCO & 2017 \\
\hline 02019.000264/2017-46 & 9051647 & $E$ & Pesca & $14 / 03 / 2017$ & $\mathrm{R} \$ 880,00$ & IPOJUCA & 2017 \\
\hline 02019.000279/2017-12 & 9096076 & $E$ & Fauna & $20 / 03 / 2017$ & $\mathrm{R} \$ 40.000,00$ & GRAVATA & 2017 \\
\hline 02019.000291/2017-19 & 9096077 & $E$ & Outras & $29 / 03 / 2017$ & $\mathrm{R} \$ 2.500,00$ & XEXEU & 2017 \\
\hline \multirow[t]{2}{*}{$02019.100184 / 2017-90$} & 9096078 & $E$ & Outras & 29/03/2017 & $\mathrm{R} \$ 2.500,00$ & XEXEU & 2017 \\
\hline & 9051054 & $E$ & $\begin{array}{l}\text { Cadastro Técnico } \\
\text { Federal }\end{array}$ & $31 / 03 / 2017$ & $\mathrm{R} \$ 4.500,00$ & RECIFE & 2017 \\
\hline \multirow[t]{2}{*}{ 02019.100839/2017-20 } & 9051058 & $E$ & $\begin{array}{l}\text { Cadastro Técnico } \\
\text { Federal }\end{array}$ & $31 / 03 / 2017$ & $\mathrm{R} \$ 4.500,00$ & RECIFE & 2017 \\
\hline & 9051059 & $E$ & $\begin{array}{l}\text { Cadastro Técnico } \\
\text { Federal }\end{array}$ & $31 / 03 / 2017$ & $\mathrm{R} \$ 1.300,00$ & RECIFE & 2017 \\
\hline 02019.000277/2017-15 & 7131 & $E$ & Controle ambiental & $31 / 03 / 2017$ & $\mathrm{R} \$ 2.500,00$ & SERTANIA & 2017 \\
\hline $02019.000278 / 2017-60$ & 7133 & $E$ & Outras & $31 / 03 / 2017$ & $\mathrm{R} \$ 10.500,00$ & SERTANIA & 2017 \\
\hline 02019.000289/2017-40 & 7135 & $E$ & Fauna & $01 / 04 / 2017$ & $\mathrm{R} \$ 13.500,00$ & PESQUEIRA & 2017 \\
\hline $02019.000290 / 2017-74$ & 7137 & $E$ & Fauna & $06 / 04 / 2017$ & $\mathrm{R} \$ 2.000,00$ & ARCOVERDE & 2017 \\
\hline 02019.000336/2017-55 & 9128227 & $E$ & $\begin{array}{l}\text { Cadastro Técnico } \\
\text { Federal }\end{array}$ & $10 / 04 / 2017$ & $\mathrm{R} \$ 2.500,00$ & RECIFE & 2017 \\
\hline 02019.000327/2017-64 & 9049768 & $E$ & $\begin{array}{l}\text { Cadastro Técnico } \\
\text { Federal }\end{array}$ & $10 / 04 / 2017$ & $\mathrm{R} \$ 2.500,00$ & SERTANIA & 2017 \\
\hline 02019.000326/2017-10 & 9049762 & $E$ & $\begin{array}{l}\text { Cadastro Técnico } \\
\text { Federal }\end{array}$ & $10 / 04 / 2017$ & $\mathrm{R} \$ 2.500,00$ & GRAVATA & 2017 \\
\hline 02019.000337/2017-08 & 9209 & $E$ & $\begin{array}{l}\text { Cadastro Técnico } \\
\text { Federal }\end{array}$ & $11 / 04 / 2017$ & $\mathrm{R} \$ 2.500,00$ & RECIFE & 2017 \\
\hline 02019.000334/2017-66 & 9096079 & $E$ & $\begin{array}{l}\text { Cadastro Técnico } \\
\text { Federal }\end{array}$ & $11 / 04 / 2017$ & $\mathrm{R} \$ 2.500,00$ & RECIFE & 2017 \\
\hline 02019.000330/2017-88 & 9089689 & $E$ & $\begin{array}{l}\text { Cadastro Técnico } \\
\text { Federal }\end{array}$ & $11 / 04 / 2017$ & $\mathrm{R} \$ 2.500,00$ & OLINDA & 2017 \\
\hline 02019.000331/2017-22 & 9089690 & E & $\begin{array}{l}\text { Cadastro Técnico } \\
\text { Federal }\end{array}$ & $11 / 04 / 2017$ & $\mathrm{R} \$ 2.500,00$ & RECIFE & 2017 \\
\hline 02019.000338/2017-44 & 9210 & $E$ & $\begin{array}{l}\text { Cadastro Técnico } \\
\text { Federal }\end{array}$ & $11 / 04 / 2017$ & $\mathrm{R} \$ 2.500,00$ & RECIFE & 2017 \\
\hline 02019.000328/2017-17 & 9051659 & $E$ & $\begin{array}{l}\text { Cadastro Técnico } \\
\text { Federal }\end{array}$ & $11 / 04 / 2017$ & $\mathrm{R} \$ 2.500,00$ & RECIFE & 2017 \\
\hline 02019.000335/2017-19 & 9096080 & $E$ & $\begin{array}{l}\text { Cadastro Técnico } \\
\text { Federal }\end{array}$ & $11 / 04 / 2017$ & $\mathrm{R} \$ 2.500,00$ & RECIFE & 2017 \\
\hline 02019.000329/2017-53 & 9051661 & $E$ & $\begin{array}{l}\text { Cadastro Técnico } \\
\text { Federal }\end{array}$ & $11 / 04 / 2017$ & $\mathrm{R} \$ 2.500,00$ & RECIFE & 2017 \\
\hline 02019.000301/2017-16 & 9134040 & $E$ & $\begin{array}{l}\text { Cadastro Técnico } \\
\text { Federal }\end{array}$ & $11 / 04 / 2017$ & $\mathrm{R} \$ 2.500,00$ & $\begin{array}{l}\text { CABO DE SANTO } \\
\text { AGOSTINHO }\end{array}$ & 2017 \\
\hline 02019.000300/2017-71 & 9089692 & $E$ & $\begin{array}{l}\text { Cadastro Técnico } \\
\text { Federal }\end{array}$ & $11 / 04 / 2017$ & $\mathrm{R} \$ 2.500,00$ & PETROLINA & 2017 \\
\hline 02019.000332/2017-77 & 9089773 & $\mathrm{E}$ & $\begin{array}{l}\text { Cadastro Técnico } \\
\text { Federal }\end{array}$ & $11 / 04 / 2017$ & $\mathrm{R} \$ 2.500,00$ & RECIFE & 2017 \\
\hline
\end{tabular}




\begin{tabular}{|c|c|c|c|c|c|c|c|}
\hline 02019.000333/2017-11 & 9089774 & $E$ & $\begin{array}{l}\text { Cadastro Técnico } \\
\text { Federal }\end{array}$ & $11 / 04 / 2017$ & $\mathrm{R} \$ 2.500,00$ & RECIFE & 2017 \\
\hline 02019.000324/2017-21 & 7138 & $E$ & $\begin{array}{l}\text { Cadastro Técnico } \\
\text { Federal }\end{array}$ & $12 / 04 / 2017$ & $\mathrm{R} \$ 2.500,00$ & RECIFE & 2017 \\
\hline 02019.000325/2017-75 & 7139 & $E$ & $\begin{array}{l}\text { Cadastro Técnico } \\
\text { Federal }\end{array}$ & $12 / 04 / 2017$ & $\mathrm{R} \$ 2.500,00$ & CAMARAGIBE & 2017 \\
\hline 02019.000298/2017-31 & 9051660 & $E$ & $\begin{array}{l}\text { Cadastro Técnico } \\
\text { Federal }\end{array}$ & $12 / 04 / 2017$ & $\mathrm{R} \$ 2.500,00$ & RECIFE & 2017 \\
\hline 02019.000299/2017-85 & 9051662 & $E$ & $\begin{array}{l}\text { Cadastro Técnico } \\
\text { Federal }\end{array}$ & $12 / 04 / 2017$ & $\mathrm{R} \$ 2.500,00$ & RECIFE & 2017 \\
\hline 02019.100344/2017-09 & 9135978 & $E$ & Fauna & $17 / 04 / 2017$ & $\mathrm{R} \$ 1.000,00$ & RECIFE & 2017 \\
\hline 02019.000355/2017-81 & 9051664 & $E$ & Pesca & $18 / 04 / 2017$ & $\mathrm{R} \$ 12.180,00$ & TAMANDARE & 2017 \\
\hline 02019.000352/2017-48 & 9049769 & $E$ & Pesca & $18 / 04 / 2017$ & $\mathrm{R} \$ 12.180,00$ & TAMANDARE & 2017 \\
\hline 02019.000359/2017-60 & 9130718 & $E$ & Pesca & $18 / 04 / 2017$ & $\mathrm{R} \$ 12.180,00$ & TAMANDARE & 2017 \\
\hline \multirow[t]{2}{*}{ 02019.000353/2017-92 } & 9049770 & $E$ & Pesca & $18 / 04 / 2017$ & $\mathrm{R} \$ 12.180,00$ & TAMANDARE & 2017 \\
\hline & 9130720 & $E$ & Pesca & $18 / 04 / 2017$ & $\mathrm{R} \$ 12.180,00$ & TAMANDARE & 2017 \\
\hline 02019.000356/2017-26 & 9051665 & $E$ & Pesca & $18 / 04 / 2017$ & $\mathrm{R} \$ 12.180,00$ & TAMANDARE & 2017 \\
\hline 02019.000361/2017-39 & 9130721 & $E$ & Pesca & $19 / 04 / 2017$ & $\mathrm{R} \$ 160.000,00$ & $\begin{array}{l}\text { SAO JOSE DA } \\
\text { COROA GRANDE }\end{array}$ & 2017 \\
\hline 02019.000354/2017-37 & 9049771 & $E$ & Pesca & $20 / 04 / 2017$ & $\mathrm{R} \$ 510.000,00$ & TAMANDARE & 2017 \\
\hline 02019.100185/2017-34 & 9096081 & $E$ & Fauna & $21 / 04 / 2017$ & $\mathrm{R} \$ 500,00$ & TAMANDARE & 2017 \\
\hline \multirow[t]{2}{*}{ 02601.100032/2017-17 } & 9045507 & $E$ & Fauna & $11 / 05 / 2017$ & $\mathrm{R} \$ 23.000,00$ & PETROLINA & 2017 \\
\hline & 9135977 & $E$ & Pesca & $17 / 05 / 2017$ & $\mathrm{R} \$ 500,00$ & $\begin{array}{l}\text { SAO JOSE DA } \\
\text { COROA GRANDE }\end{array}$ & 2017 \\
\hline 02019.100347/2017-34 & 9135979 & $E$ & Pesca & $19 / 05 / 2017$ & $R \$ 500,00$ & $\begin{array}{l}\text { SAO JOSE DA } \\
\text { COROA GRANDE }\end{array}$ & 2017 \\
\hline 02019.100296/2017-41 & 9089776 & $E$ & Pesca & $19 / 05 / 2017$ & $R \$ 500,00$ & SIRINHAEM & 2017 \\
\hline 02019.100294/2017-51 & 9089674 & $E$ & Pesca & $19 / 05 / 2017$ & $\mathrm{R} \$ 500,00$ & SIRINHAEM & 2017 \\
\hline 02019.100346/2017-90 & 9089777 & $E$ & Pesca & $20 / 05 / 2017$ & $\mathrm{R} \$ 1.160,00$ & BARREIROS & 2017 \\
\hline 02019.100293/2017-15 & 9089778 & $E$ & Pesca & $20 / 05 / 2017$ & $\mathrm{R} \$ 500,00$ & SIRINHAEM & 2017 \\
\hline 02019.100380/2017-64 & 9096161 & $E$ & Fauna & $25 / 05 / 2017$ & $\mathrm{R} \$ 17.500,00$ & OLINDA & 2017 \\
\hline 02019.100393/2017-33 & 9089671 & E & Pesca & $26 / 05 / 2017$ & $\mathrm{R} \$ 5.860,00$ & $\begin{array}{l}\text { SAO LOURENCO DA } \\
\text { MATA }\end{array}$ & 2017 \\
\hline 02019.100781/2017-14 & 9089775 & $E$ & Fauna & $31 / 05 / 2017$ & $\mathrm{R} \$ 19.000,00$ & BUIQUE & 2017 \\
\hline 02007.101101/2017-19 & 9129303 & $E$ & Controle ambiental & $07 / 06 / 2017$ & $\mathrm{R} \$ 1.500,00$ & CARUARU & 2017 \\
\hline 02007.101102/2017-63 & 9129304 & $E$ & $\begin{array}{l}\text { Cadastro Técnico } \\
\text { Federal }\end{array}$ & 09/06/2017 & $R \$ 150,00$ & CARUARU & 2017 \\
\hline 02019.100577/2017-01 & 9051353 & $E$ & $\begin{array}{l}\text { Cadastro Técnico } \\
\text { Federal }\end{array}$ & $14 / 06 / 2017$ & $\mathrm{R} \$ 1.800,00$ & PAULISTA & 2017 \\
\hline 02019.100865/2017-58 & 9173446 & $E$ & $\begin{array}{l}\text { Cadastro Técnico } \\
\text { Federal }\end{array}$ & 05/07/2017 & $\mathrm{R} \$ 1.300,00$ & RECIFE & 2017 \\
\hline 02019.100985/2017-55 & 9168713 & $E$ & $\begin{array}{l}\text { Cadastro Técnico } \\
\text { Federal }\end{array}$ & $12 / 07 / 2017$ & $\mathrm{R} \$ 4.500,00$ & RECIFE & 2017 \\
\hline 02019.100983/2017-66 & 9165756 & $E$ & $\begin{array}{l}\text { Cadastro Técnico } \\
\text { Federal }\end{array}$ & $13 / 07 / 2017$ & $\mathrm{R} \$ 1.100,00$ & RECIFE & 2017 \\
\hline 02019.100973/2017-21 & 9168714 & $E$ & Outras & $13 / 07 / 2017$ & $R \$ 50.500,00$ & RECIFE & 2017 \\
\hline \multirow[t]{3}{*}{ 02019.100982/2017-11 } & 9168941 & $E$ & Outras & $13 / 07 / 2017$ & $\mathrm{R} \$ 10.500,00$ & RECIFE & 2017 \\
\hline & 9143058 & $E$ & Flora & $19 / 07 / 2017$ & $\mathrm{R} \$ 33.000,00$ & XEXEU & 2017 \\
\hline & 9173495 & $E$ & Outras & $24 / 07 / 2017$ & $\mathrm{R} \$ 1.500,00$ & AGRESTINA & 2017 \\
\hline 02019.101174/2017-71 & 9173694 & $E$ & $\begin{array}{l}\text { Cadastro Técnico } \\
\text { Federal }\end{array}$ & $26 / 07 / 2017$ & $\mathrm{R} \$ 1.200,00$ & RECIFE & 2017 \\
\hline 02019.101149/2017-98 & 9173695 & $E$ & $\begin{array}{l}\text { Cadastro Técnico } \\
\text { Federal }\end{array}$ & $26 / 07 / 2017$ & $\mathrm{R} \$ 1.200,00$ & RECIFE & 2017 \\
\hline 02019.101110/2017-71 & 9168715 & $E$ & $\begin{array}{l}\text { Cadastro Técnico } \\
\text { Federal }\end{array}$ & $27 / 07 / 2017$ & $\mathrm{R} \$ 1.200,00$ & RECIFE & 2017 \\
\hline 02019.101178/2017-50 & 9173698 & $E$ & $\begin{array}{l}\text { Cadastro Técnico } \\
\text { Federal }\end{array}$ & $27 / 07 / 2017$ & $\mathrm{R} \$ 1.200,00$ & RECIFE & 2017 \\
\hline 02019.101183/2017-62 & 9173246 & $E$ & $\begin{array}{l}\text { Cadastro Técnico } \\
\text { Federal }\end{array}$ & $27 / 07 / 2017$ & $\mathrm{R} \$ 1.200,00$ & RECIFE & 2017 \\
\hline 02019.101119/2017-81 & 9168719 & $E$ & $\begin{array}{l}\text { Cadastro Técnico } \\
\text { Federal }\end{array}$ & $27 / 07 / 2017$ & $\mathrm{R} \$ 1.200,00$ & RECIFE & 2017 \\
\hline 02019.101112/2017-60 & 9173248 & $E$ & $\begin{array}{l}\text { Cadastro Técnico } \\
\text { Federal }\end{array}$ & $27 / 07 / 2017$ & $\mathrm{R} \$ 1.200,00$ & RECIFE & 2017 \\
\hline
\end{tabular}




\begin{tabular}{|c|c|c|c|c|c|c|c|}
\hline 02019.101182/2017-18 & 9173249 & $E$ & $\begin{array}{l}\text { Cadastro Técnico } \\
\text { Federal }\end{array}$ & $27 / 07 / 2017$ & $\mathrm{R} \$ 1.200,00$ & RECIFE & 2017 \\
\hline 02019.101108/2017-00 & 9173696 & $E$ & $\begin{array}{l}\text { Cadastro Técnico } \\
\text { Federal }\end{array}$ & $27 / 07 / 2017$ & $\mathrm{R} \$ 1.100,00$ & RECIFE & 2017 \\
\hline 02019.101176/2017-61 & 9173697 & E & $\begin{array}{l}\text { Cadastro Técnico } \\
\text { Federal }\end{array}$ & 27/07/2017 & $\mathrm{R} \$ 1.100,00$ & RECIFE & 2017 \\
\hline 02019.101120/2017-14 & 9168716 & E & $\begin{array}{l}\text { Cadastro Técnico } \\
\text { Federal }\end{array}$ & 27/07/2017 & $\mathrm{R} \$ 1.100,00$ & RECIFE & 2017 \\
\hline 02019.101139/2017-52 & 9168717 & E & $\begin{array}{l}\text { Cadastro Técnico } \\
\text { Federal }\end{array}$ & 27/07/2017 & $\mathrm{R} \$ 1.100,00$ & RECIFE & 2017 \\
\hline 02019.101111/2017-15 & 9168718 & E & $\begin{array}{l}\text { Cadastro Técnico } \\
\text { Federal }\end{array}$ & $27 / 07 / 2017$ & $\mathrm{R} \$ 1.100,00$ & RECIFE & 2017 \\
\hline 02019.101138/2017-16 & 9173250 & E & $\begin{array}{l}\text { Cadastro Técnico } \\
\text { Federal }\end{array}$ & 28/07/2017 & $R \$ 1.200,00$ & RECIFE & 2017 \\
\hline 02019.101181/2017-73 & 9173251 & $\mathrm{E}$ & $\begin{array}{l}\text { Cadastro Técnico } \\
\text { Federal }\end{array}$ & 28/07/2017 & $R \$ 1.200,00$ & RECIFE & 2017 \\
\hline 02019.101137/2017-63 & 9173252 & E & $\begin{array}{l}\text { Cadastro Técnico } \\
\text { Federal }\end{array}$ & 28/07/2017 & $\mathrm{R} \$ 1.100,00$ & RECIFE & 2017 \\
\hline 02019.101238/2017-34 & 9173699 & E & $\begin{array}{l}\text { Cadastro Técnico } \\
\text { Federal }\end{array}$ & 28/07/2017 & $\mathrm{R} \$ 1.000,00$ & RECIFE & 2017 \\
\hline 02019.101235/2017-09 & 9173702 & E & $\begin{array}{l}\text { Cadastro Técnico } \\
\text { Federal }\end{array}$ & $31 / 07 / 2017$ & $R \$ 1.200,00$ & RECIFE & 2017 \\
\hline 02019.101136/2017-19 & 9173253 & E & $\begin{array}{l}\text { Cadastro Técnico } \\
\text { Federal }\end{array}$ & $31 / 07 / 2017$ & $R \$ 1.200,00$ & RECIFE & 2017 \\
\hline 02019.101141/2017-21 & 9168724 & E & $\begin{array}{l}\text { Cadastro Técnico } \\
\text { Federal }\end{array}$ & $31 / 07 / 2017$ & $R \$ 1.200,00$ & RECIFE & 2017 \\
\hline 02019.101143/2017-11 & 9168725 & E & $\begin{array}{l}\text { Cadastro Técnico } \\
\text { Federal }\end{array}$ & $31 / 07 / 2017$ & $R \$ 1.200,00$ & RECIFE & 2017 \\
\hline 02019.101144/2017-65 & 9169032 & E & $\begin{array}{l}\text { Cadastro Técnico } \\
\text { Federal }\end{array}$ & $31 / 07 / 2017$ & $\mathrm{R} \$ 1.100,00$ & RECIFE & 2017 \\
\hline 02019.101201/2017-14 & 9169033 & $\mathrm{E}$ & $\begin{array}{l}\text { Cadastro Técnico } \\
\text { Federal }\end{array}$ & $31 / 07 / 2017$ & $\mathrm{R} \$ 1.100,00$ & RECIFE & 2017 \\
\hline 02019.101140/2017-87 & 9168721 & $E$ & $\begin{array}{l}\text { Cadastro Técnico } \\
\text { Federal }\end{array}$ & $31 / 07 / 2017$ & $\mathrm{R} \$ 1.100,00$ & RECIFE & 2017 \\
\hline 02019.101202/2017-51 & 9169034 & $E$ & $\begin{array}{l}\text { Cadastro Técnico } \\
\text { Federal }\end{array}$ & $31 / 07 / 2017$ & $\mathrm{R} \$ 1.100,00$ & RECIFE & 2017 \\
\hline 02019.101142/2017-76 & 9168722 & $E$ & $\begin{array}{l}\text { Cadastro Técnico } \\
\text { Federal }\end{array}$ & $31 / 07 / 2017$ & $\mathrm{R} \$ 1.100,00$ & RECIFE & 2017 \\
\hline $02019.101146 / 2017-54$ & 9168723 & $E$ & $\begin{array}{l}\text { Cadastro Técnico } \\
\text { Federal }\end{array}$ & $31 / 07 / 2017$ & $\mathrm{R} \$ 1.100,00$ & RECIFE & 2017 \\
\hline 02019.101151/2017-67 & 9173701 & $E$ & $\begin{array}{l}\text { Cadastro Técnico } \\
\text { Federal }\end{array}$ & $31 / 07 / 2017$ & $\mathrm{R} \$ 1.000,00$ & RECIFE & 2017 \\
\hline 02019.101267/2017-04 & 9169037 & $E$ & $\begin{array}{l}\text { Cadastro Técnico } \\
\text { Federal }\end{array}$ & $01 / 08 / 2017$ & $\mathrm{R} \$ 1.200,00$ & RECIFE & 2017 \\
\hline 02019.101280/2017-55 & 9169038 & $E$ & $\begin{array}{l}\text { Cadastro Técnico } \\
\text { Federal }\end{array}$ & 02/08/2017 & $\mathrm{R} \$ 1.200,00$ & RECIFE & 2017 \\
\hline 02019.101276/2017-97 & 9169040 & $E$ & $\begin{array}{l}\text { Cadastro Técnico } \\
\text { Federal }\end{array}$ & 02/08/2017 & $\mathrm{R} \$ 1.200,00$ & RECIFE & 2017 \\
\hline 02019.101279/2017-21 & 9169039 & $E$ & $\begin{array}{l}\text { Cadastro Técnico } \\
\text { Federal }\end{array}$ & 02/08/2017 & $\mathrm{R} \$ 1.100,00$ & RECIFE & 2017 \\
\hline 02019.101659/2017-65 & 9173447 & $E$ & $\begin{array}{l}\text { Cadastro Técnico } \\
\text { Federal }\end{array}$ & $24 / 08 / 2017$ & $\mathrm{R} \$ 1.200,00$ & RECIFE & 2017 \\
\hline 02019.101715/2017-61 & 9173448 & E & $\begin{array}{l}\text { Cadastro Técnico } \\
\text { Federal }\end{array}$ & $31 / 08 / 2017$ & $\mathrm{R} \$ 1.200,00$ & TIMBAUBA & 2017 \\
\hline 02003.101741/2017-69 & 9140438 & $E$ & Fauna & $13 / 09 / 2017$ & $\mathrm{R} \$ 5.500,00$ & GARANHUNS & 2017 \\
\hline 02019.101952/2017-22 & 9173449 & $E$ & $\begin{array}{l}\text { Cadastro Técnico } \\
\text { Federal }\end{array}$ & $14 / 09 / 2017$ & $\mathrm{R} \$ 1.500,00$ & CARUARU & 2017 \\
\hline 02019.102178/2017-77 & 9168728 & $E$ & Flora & $20 / 09 / 2017$ & $\mathrm{R} \$ 18.326,40$ & CARPINA & 2017 \\
\hline 02019.102163/2017-17 & 9168729 & $\mathrm{E}$ & Flora & $22 / 09 / 2017$ & $\mathrm{R} \$ 6.000,00$ & SAO BENTO DO UNA & 2017 \\
\hline 02019.102675/2017-75 & 9169041 & $E$ & Flora & $27 / 09 / 2017$ & $\mathrm{R} \$ 3.600,00$ & MACHADOS & 2017 \\
\hline 02019.102133/2017-01 & 9173450 & $\mathrm{E}$ & Controle ambiental & $28 / 09 / 2017$ & $\mathrm{R} \$ 300.000,00$ & OLINDA & 2017 \\
\hline 02019.102207/2017-09 & 9168731 & $E$ & Fauna & 28/09/2017 & $\mathrm{R} \$ 5.000,00$ & $\begin{array}{l}\text { SANTA CRUZ DO } \\
\text { CAPIBARIBE }\end{array}$ & 2017 \\
\hline 02019.102602/2017-83 & 9169047 & $\mathrm{E}$ & Flora & 29/09/2017 & $\mathrm{R} \$ 6.064,20$ & CARUARU & 2017 \\
\hline 02019.102677/2017-64 & 9169046 & $E$ & Flora & 29/09/2017 & $\mathrm{R} \$ 5.968,20$ & CUPIRA & 2017 \\
\hline 02019.102676/2017-10 & 9169048 & $E$ & Flora & 29/09/2017 & $\mathrm{R} \$ 5.700,00$ & GRAVATA & 2017 \\
\hline
\end{tabular}




\begin{tabular}{|c|c|c|c|c|c|c|c|}
\hline 02001.121915/2017-20 & 9194215 & $E$ & $\begin{array}{l}\text { Cadastro Técnico } \\
\text { Federal }\end{array}$ & 04/10/2017 & $\mathrm{R} \$ 9.000,00$ & RECIFE & 2017 \\
\hline 02001.122317/2017-78 & 9143537 & $E$ & $\begin{array}{l}\text { Cadastro Técnico } \\
\text { Federal }\end{array}$ & 05/10/2017 & $\mathrm{R} \$ 9.000,00$ & PRIMAVERA & 2017 \\
\hline 02019.102589/2017-62 & 9169045 & $E$ & Flora & $10 / 10 / 2017$ & $\mathrm{R} \$ 86.000,00$ & AFRANIO & 2017 \\
\hline 02019.102638/2017-67 & 9168727 & $E$ & Flora & $10 / 10 / 2017$ & $\mathrm{R} \$ 43.000,00$ & AFRANIO & 2017 \\
\hline 02019.102645/2017-69 & 9169044 & $E$ & Flora & $10 / 10 / 2017$ & $R \$ 25.000,00$ & AFRANIO & 2017 \\
\hline 02019.102673/2017-86 & 9168732 & $E$ & Flora & $10 / 10 / 2017$ & $\mathrm{R} \$ 25.000,00$ & AFRANIO & 2017 \\
\hline 02019.102608/2017-51 & 9169049 & $E$ & Flora & $10 / 10 / 2017$ & $R \$ 21.000,00$ & AFRANIO & 2017 \\
\hline 02019.102583/2017-95 & 9169051 & $E$ & $\begin{array}{l}\text { Cadastro Técnico } \\
\text { Federal }\end{array}$ & $11 / 10 / 2017$ & $\mathrm{R} \$ 5.000,00$ & AFRANIO & 2017 \\
\hline $02019.102674 / 2017-21$ & 9168734 & $E$ & Flora & $11 / 10 / 2017$ & $\mathrm{R} \$ 30.000,00$ & AFRANIO & 2017 \\
\hline 02019.102613/2017-63 & 9169052 & $E$ & Flora & $14 / 10 / 2017$ & $\mathrm{R} \$ 51.000,00$ & BODOCO & 2017 \\
\hline 02019.102646/2017-11 & 9169053 & $E$ & Flora & $14 / 10 / 2017$ & $\mathrm{R} \$ 31.000,00$ & BODOCO & 2017 \\
\hline 02019.102588/2017-18 & 9169054 & $E$ & Flora & $14 / 10 / 2017$ & $\mathrm{R} \$ 9.000,00$ & BODOCO & 2017 \\
\hline 02019.102585/2017-84 & 9169055 & $E$ & Flora & $15 / 10 / 2017$ & $\mathrm{R} \$ 101.000,00$ & BODOCO & 2017 \\
\hline 02019.102611/2017-74 & 9169056 & $E$ & $\begin{array}{l}\text { Cadastro Técnico } \\
\text { Federal }\end{array}$ & $17 / 10 / 2017$ & $\mathrm{R} \$ 1.300,00$ & PETROLINA & 2017 \\
\hline \multirow[t]{2}{*}{ 02019.102610/2017-20 } & 9169059 & $E$ & $\begin{array}{l}\text { Cadastro Técnico } \\
\text { Federal }\end{array}$ & $18 / 10 / 2017$ & $\mathrm{R} \$ 1.800,00$ & PETROLINA & 2017 \\
\hline & 9169057 & $E$ & Outras & $18 / 10 / 2017$ & $\mathrm{R} \$ 1.000,00$ & PETROLINA & 2017 \\
\hline 02019.102576/2017-93 & 9168943 & $E$ & Controle ambiental & $19 / 10 / 2017$ & $\mathrm{R} \$ 50.500,00$ & RECIFE & 2017 \\
\hline 02019.102629/2017-76 & 9173496 & $E$ & Fauna & 26/10/2017 & $R \$ 10.000,00$ & CAMARAGIBE & 2017 \\
\hline 02019.102648/2017-01 & 9169050 & $E$ & Flora & $26 / 10 / 2017$ & $\mathrm{R} \$ 48.000,00$ & SERRA TALHADA & 2017 \\
\hline \multirow[t]{2}{*}{ 02019.102670/2017-42 } & 9169060 & $E$ & Flora & $26 / 10 / 2017$ & $\mathrm{R} \$ 27.000,00$ & SERRA TALHADA & 2017 \\
\hline & 9138566 & $E$ & $\begin{array}{l}\text { Cadastro Técnico } \\
\text { Federal }\end{array}$ & $31 / 10 / 2017$ & $\mathrm{R} \$ 2.500,00$ & JOAO ALFREDO & 2017 \\
\hline 02019.102749/2017-73 & 9168735 & $E$ & Fauna & $01 / 11 / 2017$ & $\mathrm{R} \$ 17.000,00$ & $\begin{array}{l}\text { SAO JOSE DA } \\
\text { COROA GRANDE }\end{array}$ & 2017 \\
\hline 02019.102748/2017-29 & 9168736 & $E$ & Fauna & $01 / 11 / 2017$ & $\mathrm{R} \$ 7.000,00$ & $\begin{array}{l}\text { SAO JOSE DA } \\
\text { COROA GRANDE }\end{array}$ & 2017 \\
\hline 02019.102743/2017-04 & 9168737 & $E$ & Outras & 06/11/2017 & $\mathrm{R} \$ 2.500,00$ & RIO FORMOSO & 2017 \\
\hline $02001.127076 / 2017-53$ & 9128872 & $E$ & Controle ambiental & $14 / 11 / 2017$ & $\mathrm{R} \$ 45.000,00$ & RECIFE & 2017 \\
\hline 02019.102866/2017-37 & 9173347 & $E$ & Flora & $15 / 11 / 2017$ & $\mathrm{R} \$ 24.000,00$ & BUIQUE & 2017 \\
\hline 02019.102934/2017-68 & 9169061 & $E$ & Fauna & $16 / 11 / 2017$ & $R \$ 20.500,00$ & BONITO & 2017 \\
\hline 02019.102917/2017-21 & 9173350 & $E$ & Flora & $17 / 11 / 2017$ & $\mathrm{R} \$ 336.000,00$ & IBIMIRIM & 2017 \\
\hline \multirow[t]{2}{*}{ 02019.102864/2017-48 } & 9173786 & $E$ & Flora & $17 / 11 / 2017$ & $\mathrm{R} \$ 124.000,00$ & IBIMIRIM & 2017 \\
\hline & 9173786 & $E$ & Flora & $17 / 11 / 2017$ & $\mathrm{R} \$ 124.000,00$ & IBIMIRIM & 2017 \\
\hline 02019.102863/2017-01 & 9138572 & $E$ & Outras & $17 / 11 / 2017$ & $\mathrm{R} \$ 21.000,00$ & IBIMIRIM & 2017 \\
\hline 02019.102928/2017-19 & 9173355 & $E$ & Flora & $18 / 11 / 2017$ & $\mathrm{R} \$ 1.200,00$ & IBIMIRIM & 2017 \\
\hline 02019.102929/2017-55 & 9173356 & $E$ & Outras & $18 / 11 / 2017$ & $\mathrm{R} \$ 21.000,00$ & IBIMIRIM & 2017 \\
\hline \multirow[t]{2}{*}{ 02019.103091/2017-17 } & 9138638 & $E$ & Fauna & $28 / 11 / 2017$ & $\mathrm{R} \$ 500,00$ & $\begin{array}{l}\text { SAO LOURENCO DA } \\
\text { MATA }\end{array}$ & 2017 \\
\hline & 9173367 & $E$ & $\begin{array}{l}\text { Cadastro Técnico } \\
\text { Federal }\end{array}$ & $13 / 12 / 2017$ & $\mathrm{R} \$ 1.000,00$ & OLINDA & 2017 \\
\hline $02019.000508 / 2018-71$ & 9173369 & $E$ & Pesca & $18 / 12 / 2017$ & $\mathrm{R} \$ 1.040,00$ & IPOJUCA & 2017 \\
\hline 02019.103389/2017-27 & 9168933 & $E$ & Fauna & $19 / 12 / 2017$ & $\mathrm{R} \$ 500,00$ & RECIFE & 2017 \\
\hline 02019.103379/2017-91 & 9168934 & $E$ & Fauna & $19 / 12 / 2017$ & $\mathrm{R} \$ 500,00$ & RECIFE & 2017 \\
\hline $02019.103381 / 2017-61$ & 9168935 & $E$ & Fauna & $19 / 12 / 2017$ & $\mathrm{R} \$ 500,00$ & RECIFE & 2017 \\
\hline 02019.103384/2017-02 & 9168945 & $E$ & Fauna & $19 / 12 / 2017$ & $\mathrm{R} \$ 500,00$ & RECIFE & 2017 \\
\hline 02019.103375/2017-11 & 9168946 & $E$ & Fauna & $19 / 12 / 2017$ & $\mathrm{R} \$ 500,00$ & RECIFE & 2017 \\
\hline 02019.103388/2017-82 & 9168936 & $E$ & Fauna & 19/12/2017 & $\mathrm{R} \$ 500,00$ & RECIFE & 2017 \\
\hline 02019.103386/2017-93 & 9168937 & $E$ & Fauna & $19 / 12 / 2017$ & $R \$ 500,00$ & RECIFE & 2017 \\
\hline 02019.103378/2017-47 & 9168938 & $E$ & Fauna & $19 / 12 / 2017$ & $\mathrm{R} \$ 500,00$ & RECIFE & 2017 \\
\hline 02019.103374/2017-69 & 9168939 & $E$ & Fauna & $19 / 12 / 2017$ & $\mathrm{R} \$ 500,00$ & RECIFE & 2017 \\
\hline 02019.103377/2017-01 & 9168940 & $E$ & Fauna & $19 / 12 / 2017$ & $\mathrm{R} \$ 500,00$ & RECIFE & 2017 \\
\hline 02019.103380/2017-16 & 9168947 & $E$ & Fauna & $19 / 12 / 2017$ & $\mathrm{R} \$ 500,00$ & RECIFE & 2017 \\
\hline 02019.103382/2017-13 & 9168948 & $E$ & Fauna & $19 / 12 / 2017$ & $\mathrm{R} \$ 500,00$ & RECIFE & 2017 \\
\hline 02019.103385/2017-49 & 9168949 & $E$ & Fauna & $19 / 12 / 2017$ & $R \$ 500,00$ & RECIFE & 2017 \\
\hline 02019.103383/2017-50 & 9168950 & $E$ & Fauna & 19/12/2017 & $\mathrm{R} \$ 500,00$ & RECIFE & 2017 \\
\hline 02019.103390/2017-51 & 9168951 & $E$ & Fauna & 19/12/2017 & $R \$ 500,00$ & RECIFE & 2017 \\
\hline
\end{tabular}




\begin{tabular}{|l|l|l|l|l|l|l|l|}
\hline $02019.103392 / 2017-41$ & 9168953 & $\mathrm{E}$ & Fauna & $19 / 12 / 2017$ & $\mathrm{R} \$ 500,00$ & $\mathrm{RECIFE}$ & 2017 \\
\hline $02019.103387 / 2017-38$ & 9168954 & $\mathrm{E}$ & Fauna & $19 / 12 / 2017$ & $\mathrm{R} \$ 500,00$ & $\mathrm{RECIFE}$ & 2017 \\
\hline $02019.103372 / 2017-70$ & 9168955 & $\mathrm{E}$ & Fauna & $19 / 12 / 2017$ & $\mathrm{R} \$ 500,00$ & $\mathrm{RECIFE}$ & 2017 \\
\hline $02019.103376 / 2017-58$ & 9168956 & $\mathrm{E}$ & Fauna & $19 / 12 / 2017$ & $\mathrm{R} \$ 500,00$ & $\mathrm{RECIFE}$ & 2017 \\
\hline $02019.103391 / 2017-04$ & 9168957 & $\mathrm{E}$ & Fauna & $19 / 12 / 2017$ & $\mathrm{R} \$ 500,00$ & $\mathrm{RECIFE}$ & 2017 \\
\hline $02019.103452 / 2017-25$ & 9168741 & $\mathrm{E}$ & Pesca & $19 / 12 / 2017$ & $\mathrm{R} \$ 880,00$ & RECIFE & 2017 \\
\hline $02016.101694 / 2017-12$ & 9143763 & $\mathrm{E}$ & Flora & $20 / 12 / 2017$ & $\mathrm{R} \$ 10.000,00$ & $\begin{array}{l}\text { SANTA MARIA DO } \\
\text { CAMBUCA }\end{array}$ & 2017 \\
\hline $02019.103453 / 2017-70$ & 9168742 & $\mathrm{E}$ & $\begin{array}{l}\text { Org. Gen. Modific. } \mathrm{e} \\
\text { Biopirataria }\end{array}$ & $21 / 12 / 2017$ & $\mathrm{R} \$ 1.100,00$ & IPOJUCA & 2017 \\
\hline $02019.103511 / 2017-65$ & 9168743 & $\mathrm{E}$ & Pesca & $26 / 12 / 2017$ & $\mathrm{R} \$ 840,00$ & OLINDA & 2017 \\
\hline & 9138646 & $\mathrm{E}$ & Fauna & $28 / 12 / 2017$ & $\mathrm{R} \$ 1.000,00$ & $\begin{array}{l}\text { SAO JOSE DA } \\
\text { COROA GRANDE }\end{array}$ & 2017 \\
\hline $02019.000485 / 2018-03$ & 9138645 & $\mathrm{E}$ & Fauna & $28 / 12 / 2017$ & $\mathrm{R} \$ 500,00$ & $\begin{array}{l}\text { SAO JOSE DA } \\
\text { COROA GRANDE }\end{array}$ & 2017 \\
\hline & & & & & &
\end{tabular}




\section{APÊNDICE C - PLANILHA DE DADOS COLETADOS DO SEI}

\begin{tabular}{|c|c|c|c|c|c|c|c|c|c|c|c|c|c|}
\hline \multicolumn{6}{|c|}{ METADADOS DO PROCESSO NO SEI } & \multicolumn{8}{|c|}{ INFORMAÇÕES COMPLEMENTARES } \\
\hline Processo $n^{\circ}$ & $\begin{array}{l}\text { Data } \\
\text { de } \\
\text { Autu } \\
\text { ação }\end{array}$ & $\begin{array}{l}\text { Tipo do } \\
\text { Processo }\end{array}$ & Especificação & $\begin{array}{l}\text { Classifi- } \\
\text { cação } \\
\text { por } \\
\text { Assun- } \\
\text { tos }\end{array}$ & Interessado(s) & MP & $\begin{array}{c}\text { Processo } \\
\text { aberto com } \\
\text { documento } \\
\text { do MP? }\end{array}$ & Processo MP & Solicitação & \begin{tabular}{|c|} 
Relac. a \\
processo \\
do \\
lbama?
\end{tabular} & Município & $\begin{array}{l}\text { Respon- } \\
\text { dido }\end{array}$ & Assunto/ Observação \\
\hline $\begin{array}{l}\text { 02019.000506/2 } \\
014-59\end{array}$ & $\begin{array}{l}05 / 05 \\
/ 2014\end{array}$ & $\begin{array}{l}\text { Fiscalização } \\
\text { Ambiental: } \\
\text { Apuração de } \\
\text { Infrações } \\
\text { Ambientais }\end{array}$ & $\begin{array}{l}\text { MINISTÉRIO } \\
\text { PUBLICO FEDERAL } \\
\text { DOC. PROCEDÊNCIA } \\
02019.000706 / 2014- \\
10\end{array}$ & 511 & & Federal & SIM & $\begin{array}{l}\text { IC } n^{0} \\
1.26 .000 .00231 \\
5 / 2003-81\end{array}$ & $\begin{array}{l}\text { Apurar notícia de } \\
\text { atividade } \\
\text { irregular de } \\
\text { carcinicultura }\end{array}$ & NÃO & Recife & SIM & $\begin{array}{l}\text { Carcinicultura; localidades: } \\
\text { llha do Zeca e manguezal } \\
\text { do Pina, nas proximidades } \\
\text { da llha de Deus, e na Vila } \\
\text { Tamandaré }\end{array}$ \\
\hline $\begin{array}{l}\text { 02019.000800/2 } \\
014-61\end{array}$ & $\begin{array}{l}15 / 08 \\
/ 2014\end{array}$ & $\begin{array}{l}\text { Fiscalização } \\
\text { Ambiental: } \\
\text { Apuração de } \\
\text { Infrações } \\
\text { Ambientais }\end{array}$ & Al $9051620 \mathrm{E}$ & 511 & $\begin{array}{l}\text { EG } \\
\text { LTDA-EPP } \\
69\end{array}$ & Estadual & NÂO & $\begin{array}{l}\text { NPU 0000054- } \\
85.2017 .8 .17 .80 \\
31-\mathrm{TT}\end{array}$ & $\begin{array}{l}\text { Esclarecimentos } \\
\text { sobre as } \\
\text { autuações feitas à } \\
\text { empresa }\end{array}$ & SIM & Olinda & SIM & $\begin{array}{l}\text { Artesanato com partes de } \\
\text { animais silvestres }\end{array}$ \\
\hline $\begin{array}{l}\text { 02019.001222/2 } \\
015-61\end{array}$ & $\begin{array}{l}25 / 08 \\
/ 2015\end{array}$ & $\begin{array}{l}\text { Fiscalização } \\
\text { Ambiental: } \\
\text { Apuração de } \\
\text { Infrações } \\
\text { Ambientais }\end{array}$ & $\begin{array}{l}\text { AUTO DE INFRAÇÃO } \\
9132 \text {-E }\end{array}$ & 511 & $\begin{array}{l}\text { JOÃOC } \\
00\end{array}$ & Estadual & NÂO & IC no 004/2018 & $\begin{array}{l}\text { Verificar situação } \\
\text { atual do ilícito }\end{array}$ & SIM & Paranatama & NÃO & $\begin{array}{l}\text { Extração de areia; Sítio OI } \\
=\end{array}$ \\
\hline $\begin{array}{l}\text { 02019.001687/2 } \\
015-11\end{array}$ & $\begin{array}{l}14 / 12 \\
/ 2015\end{array}$ & $\begin{array}{l}\text { Fiscalização } \\
\text { Ambiental: } \\
\text { Apuração de } \\
\text { Infrações } \\
\text { Ambientais }\end{array}$ & $\begin{array}{l}\text { MINISTÉRIO } \\
\text { PUBLICO FEDERAL } \\
\text { DE PERNAMBUCO } \\
\text { DOC. PROCEDÊNCIA } \\
02019.004110 / 20145- \\
61\end{array}$ & 511 & & Federal & SIM & $\begin{array}{l}\text { Notícia de Fato } \\
\text { no } \\
1.26 .005 .00012 \\
9 / 2015-09\end{array}$ & $\begin{array}{l}\text { Informar sobre } \\
\text { licenciamento de } \\
\text { sistema municipal } \\
\text { de esgotos }\end{array}$ & NÃO & Águas Belas & SIM & $\begin{array}{l}\text { Esgoto; terra indígena; } \\
\text { Fulni-ô }\end{array}$ \\
\hline $\begin{array}{l}\text { 02019.000067/2 } \\
016-46\end{array}$ & $\begin{array}{l}19 / 01 \\
/ 2016\end{array}$ & $\begin{array}{l}\text { Fiscalização } \\
\text { Ambiental: } \\
\text { Apuração de } \\
\text { Infrações } \\
\text { Ambientais }\end{array}$ & $\begin{array}{l}\text { FAB } \\
\text { Al } 7210 \mathrm{E}\end{array}$ & 511 & & Estadual & NÂO & IC no 002/2016 & $\begin{array}{l}\text { Perícia na área } \\
\text { objeto do } \mathrm{Al}\end{array}$ & SIM & Arcoverde & NÃO & Desmatamento; caatinga \\
\hline $\begin{array}{l}\text { 02019.000286/2 } \\
016-25\end{array}$ & $\begin{array}{l}01 / 03 \\
/ 2016\end{array}$ & $\begin{array}{l}\text { Biodiversidade: } \\
\text { Gestão de Flora - } \\
\text { Ordenamento e } \\
\text { Normatização }\end{array}$ & $\begin{array}{l}\text { MINISTÉRIO } \\
\text { PÚBLICO FEDERAL } \\
\text { DE PERNAMBUCO }\end{array}$ & $\begin{array}{l}100.01 \\
510\end{array}$ & $\begin{array}{l}\text { Ministério Público } \\
\text { Federal em } \\
\text { Pernambuco }\end{array}$ & Federal & SIM & $\begin{array}{l}\text { IC no } \\
08116.000475 / 9 \\
8-05\end{array}$ & $\begin{array}{l}\text { Apurar notícia de } \\
\text { degradação de } \\
\text { mangue }\end{array}$ & NÃO & $\begin{array}{l}\text { Jaboatão dos } \\
\text { Guararapes }\end{array}$ & SIM & $\begin{array}{l}\text { Degradação de mangue; } \\
\text { Loteamento Barra de } \\
\text { Jangada. }\end{array}$ \\
\hline $\begin{array}{l}\text { 02019.001565/2 } \\
016-14\end{array}$ & $\begin{array}{l}10 / 11 \\
/ 2016\end{array}$ & $\begin{array}{l}\text { Fiscalização } \\
\text { Ambiental: } \\
\text { Apuração de } \\
\text { Infrações } \\
\text { Ambientais }\end{array}$ & Al 5795-E & 511 & $\begin{array}{l}\text { Chefia da Ditec - } \\
\text { PE }\end{array}$ & Estadual & NÂO & Não informado & $\begin{array}{l}\text { Esclarecimentos } \\
\text { sobre a } \\
\text { regularização da } \\
\text { área degradada }\end{array}$ & SIM & Verdejante & SIM & Desmatamento; caatinga \\
\hline $\begin{array}{l}\text { 02019.001650/2 } \\
016-74\end{array}$ & $\begin{array}{l}02 / 12 \\
/ 2016\end{array}$ & $\begin{array}{l}\text { Demanda Externa } \\
\text { Ministério Público } \\
\text { Federal }\end{array}$ & : & 019.01 & $\begin{array}{l}\text { Ministério Público } \\
\text { Federal em } \\
\text { Pernambuco; } \\
\text { Ministério Público } \\
\text { de Pernambuco } \\
\text { (MPPE) }\end{array}$ & $\begin{array}{l}\text { Federal e } \\
\text { estadual }\end{array}$ & SIM & $\begin{array}{l}\text { Notícia de Fato } \\
\text { no } \\
1.26 .000 .00319 \\
4 / 2016-17 \\
\text { (MPF); } \\
\text { IC 006-16 } \\
\text { (MPPE) }\end{array}$ & $\begin{array}{l}\text { Análise da } \\
\text { adequação do } \\
\text { Levantamento } \\
\text { Florístico e } \\
\text { Fitossociológico }\end{array}$ & NÃO & Ipojuca & SIM & $\begin{array}{l}\text { Lua } \\
\text { Porto. }\end{array}$ \\
\hline
\end{tabular}




\begin{tabular}{|c|c|c|c|c|c|c|c|c|c|c|c|c|c|}
\hline $\begin{array}{l}02019.000333 / 2 \\
017-11\end{array}$ & $\begin{array}{l}24 / 04 \\
/ 2017\end{array}$ & $\begin{array}{l}\text { Fiscalização } \\
\text { Ambiental: } \\
\text { Apuração de } \\
\text { Infraçôes } \\
\text { Ambientais }\end{array}$ & $\begin{array}{l}\text { TCFA AUTO } \\
\text { №9089774 - E }\end{array}$ & 511 & & Estadual & NÂO & IC no 002/2018 & $\begin{array}{l}\text { Informar se houve } \\
\text { dano direto ao } \\
\text { meio ambiente }\end{array}$ & SIM & Gravatá & SIM & $\begin{array}{l}\text { CTF; declaração de porte } \\
\text { da empresa }\end{array}$ \\
\hline $\begin{array}{l}02019.000337 / 2 \\
017-08\end{array}$ & $\begin{array}{l}24 / 04 \\
/ 2017\end{array}$ & $\begin{array}{l}\text { Fiscalização } \\
\text { Ambiental: } \\
\text { Apuração de } \\
\text { Infrações } \\
\text { Ambientais }\end{array}$ & A. I. $9209-\mathrm{E}$ & 511 & 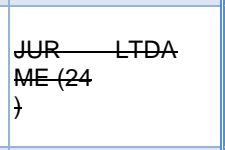 & Estadual & NÂO & IC no $003 / 2018$ & $\begin{array}{l}\text { Informar se houve } \\
\text { dano direto ao } \\
\text { meio ambiente }\end{array}$ & SIM & Recife & NÃO & $\begin{array}{l}\text { CTF; declaração de porte } \\
\text { da empresa }\end{array}$ \\
\hline $\begin{array}{l}02019.000338 / 2 \\
017-44\end{array}$ & $\begin{array}{l}24 / 04 \\
12017\end{array}$ & $\begin{array}{l}\text { Fiscalização } \\
\text { Ambiental: } \\
\text { Apuração de } \\
\text { Infrações } \\
\text { Ambientais }\end{array}$ & $\begin{array}{l}\text { TCFA AUTO №9210 - } \\
\text { E }\end{array}$ & 511 & $\begin{array}{ll}\text { NOV } & \text { LTDA. } \\
(04 & )\end{array}$ & Estadual & NÂO & IC no $001 / 2018$ & $\begin{array}{l}\text { Informar se houve } \\
\text { dano direto ao } \\
\text { meio ambiente }\end{array}$ & SIM & Gravatá & SIM & $\begin{array}{l}\text { CTF; declaração de porte } \\
\text { da empresa }\end{array}$ \\
\hline $\begin{array}{l}02019.000987 / 2 \\
017-45\end{array}$ & $\begin{array}{l}06 / 04 \\
/ 2017\end{array}$ & $\begin{array}{l}\text { Demanda Externa: } \\
\text { Ministério Público } \\
\text { Federal }\end{array}$ & & 511 & $\begin{array}{l}\text { Ministério Público } \\
\text { Federal (MPF) }\end{array}$ & Federal & SIM & $\begin{array}{l}\text { Procedimento } \\
\text { Preparatório } \mathrm{n}^{\mathrm{0}} \\
1.26 .005 .00024 \\
4 / 2017-37\end{array}$ & $\begin{array}{l}\text { Apurar as causas } \\
\text { do vazamento do } \\
\text { canal do PISF }\end{array}$ & SIM & Sertânia & NÃO & $\begin{array}{l}\text { Vazamento de canal do } \\
\text { PISF; emergência } \\
\text { ambiental }\end{array}$ \\
\hline $\begin{array}{l}\text { 02019.100062/2 } \\
017-01\end{array}$ & $\begin{array}{l}10 / 05 \\
12017\end{array}$ & $\begin{array}{l}\text { Qualidade } \\
\text { Ambiental: Gestão } \\
\text { de Resíduos e } \\
\text { Emissões }\end{array}$ & $\begin{array}{l}\text { Solicitação de } \\
\text { Inspeção }\end{array}$ & 812.42 & $\begin{array}{l}\text { MINISTERIO } \\
\text { PUBLICO DO } \\
\text { ESTADO DE } \\
\text { PERNAMBUCO } \\
\text { (MP/PE) }\end{array}$ & Estadual & SIM & IC no 002/2014 & $\begin{array}{l}\text { Inspeção técnica } \\
\text { para sobre } \\
\text { destinação de } \\
\text { resíduos sólidos } \\
\text { do município }\end{array}$ & NÃO & $\begin{array}{l}\text { São Benedito } \\
\text { do Sul }\end{array}$ & $\begin{array}{l}\text { Parcialme } \\
\text { nte }\end{array}$ & $\begin{array}{l}\text { Residuos sólidos; } \\
\text { propriedade do Vereador } \\
C\end{array}$ \\
\hline $\begin{array}{l}02019.100121 / 2 \\
017-33\end{array}$ & $\begin{array}{l}15 / 05 \\
/ 2017\end{array}$ & $\begin{array}{l}\text { Licenciamento } \\
\text { Ambiental } \\
\text { Federal: Outros }\end{array}$ & $\begin{array}{l}\text { Procedimento } \\
\text { Preparatório }\end{array}$ & 413.1 & \begin{tabular}{|l||} 
Ministério Público \\
Federal em \\
Pernambuco
\end{tabular} & Federal & SIM & $\begin{array}{l}\text { IC no } \\
1.26 .000 .00076 \\
6 / 2017-89\end{array}$ & $\begin{array}{l}\text { Informações sobre } \\
\text { o licenciamento da } \\
\text { empresa } \\
\text { Econoronha }\end{array}$ & SIM & $\begin{array}{l}\text { Fernando de } \\
\text { Noronha }\end{array}$ & SIM & $\begin{array}{l}\text { Licencimaneto ambiental; } \\
\text { Econoronha }\end{array}$ \\
\hline $\begin{array}{l}02019.100263 / 2 \\
017-09\end{array}$ & $\begin{array}{l}24 / 05 \\
12017\end{array}$ & $\begin{array}{l}\text { Biodiversidade: } \\
\text { Gestão de Flora - } \\
\text { Ordenamento e } \\
\text { Normatização }\end{array}$ & $\begin{array}{l}\text { Ministério Público } \\
\text { Federal Polo Cabo de } \\
\text { Snto Agostinho }\end{array}$ & 995 & - & Federal & SIM & $\begin{array}{l}\text { IC } n^{\circ} \\
1.26 .000 .00166 \\
0 / 2014-50\end{array}$ & $\begin{array}{l}\text { Informações sobre } \\
\text { ocupaça irregular } \\
\text { de área de } \\
\text { mangue na Vila do } \\
\text { Casado }\end{array}$ & NÃO & Sirinhaém & NÃO & $\begin{array}{l}\text { Ocupação irregular; } \\
\text { mangue; Vila do Casado }\end{array}$ \\
\hline $\begin{array}{l}02019.100286 / 2 \\
017-13\end{array}$ & $\begin{array}{l}26 / 05 \\
/ 2017\end{array}$ & $\begin{array}{l}\text { Biodiversidade: } \\
\text { Melhoria e } \\
\text { Recuperação } \\
\text { Ambiental - } \\
\text { Ordenamento e } \\
\text { Normatização }\end{array}$ & $\begin{array}{l}\text { MPF - } \\
\text { PROCURADORIA } \\
\text { POLO } \\
\text { SALGUEIRO/OURICU } \\
\text { RI. }\end{array}$ & 110.5 & & Federal & SIM & $\begin{array}{l}\text { IC } \mathrm{n}^{\circ} \\
1.26 .004 .00006 \\
6 / 2017-54\end{array}$ & $\begin{array}{l}\text { Informações sobre } \\
\text { o cumprimento } \\
\text { dos Termos de } \\
\text { Compromisso de } \\
\text { Regularização } \\
\text { Ambiental } \\
\text { (TCRAs) pelo } \\
\text { DNIT }\end{array}$ & SIM & $\begin{array}{l}\text { Salgueiro; } \\
\text { Ouricuri }\end{array}$ & SIM & $\begin{array}{l}\text { Regularização ambiental; } \\
\text { DNIT; PRM } \\
\text { Salgueiro/Ouricuri }\end{array}$ \\
\hline $\begin{array}{l}\text { 02019.100353/2 } \\
017-91\end{array}$ & $\begin{array}{l}30 / 05 \\
12017\end{array}$ & $\begin{array}{l}\text { Licenciamento } \\
\text { Ambiental } \\
\text { Federal: Outros }\end{array}$ & $\begin{array}{l}\text { Ministério Público } \\
\text { Federal }\end{array}$ & 511 & $\begin{array}{l}\text { MINISTÉRIO } \\
\text { PÚBLICO } \\
\text { FEDERAL }\end{array}$ & Federal & SIM & $\begin{array}{l}\text { Procedimento } \\
\text { Preparatório } \mathrm{n}^{\circ} \\
1.26 .005 .00010 \\
8 / 2017-47\end{array}$ & $\begin{array}{l}\text { Informar sobre } \\
\text { licenciamento da } \\
\text { Barragem do } \\
\text { Cajueiro }\end{array}$ & NÃO & Garanhuns & SIM & $\begin{array}{l}\text { Licenciamento ambiental; } \\
\text { Barragem do Cajueiro }\end{array}$ \\
\hline $\begin{array}{l}02019.100438 / 2 \\
017-70\end{array}$ & $\begin{array}{l}07 / 06 \\
/ 2017\end{array}$ & $\begin{array}{l}\text { Demanda Externa: } \\
\text { Ministério Público } \\
\text { Federal }\end{array}$ & $\begin{array}{l}\text { MINISTÉRIO } \\
\text { PÚBLICO FEDERAL - } \\
\text { PROCURADORIA DA } \\
\text { REPÚBLICA EM } \\
\text { PERNAMBUCO }\end{array}$ & $\begin{array}{l}019.01 \\
511\end{array}$ & & Federal & SIM & $\begin{array}{l}\text { Autos } \mathrm{n}^{\circ} \\
1.26 .000 .00314 \\
4 / 2015-41\end{array}$ & $\begin{array}{l}\text { Informações sobre } \\
\text { queima da palha } \\
\text { de cana-de-açúcar } \\
\text { nos municípios }\end{array}$ & NÃO & $\begin{array}{l}\text { Paudalho; } \\
\text { Carpina }\end{array}$ & SIM & $\begin{array}{l}\text { Queimadas; cana-de- } \\
\text { açúcar }\end{array}$ \\
\hline $\begin{array}{l}02019.100464 / 2 \\
017-06\end{array}$ & $\begin{array}{l}08 / 06 \\
12017\end{array}$ & $\begin{array}{l}\text { Fiscalização } \\
\text { Ambiental: } \\
\text { Apuração de } \\
\text { Infraçōes } \\
\text { Ambientais }\end{array}$ & $\begin{array}{l}\text { MINISTÉRIO } \\
\text { PÚBLICO DO } \\
\text { ESTADO DE } \\
\text { PERNAMBUCO }\end{array}$ & 995 & & Estadual & SIM & $\begin{array}{l}\text { Procedimento } \\
\text { Preparatório no } \\
027 / 2017\end{array}$ & $\begin{array}{l}\text { Averiguar se } \\
\text { incêndio atingiu a } \\
\text { APP e reserva } \\
\text { legal. }\end{array}$ & NÃO & Aliança & SIM & $\begin{array}{l}\text { Incêndio criminoso; PA } \\
\text { Sirigi - Associação } \\
\text { Mariano Sales }\end{array}$ \\
\hline
\end{tabular}




\begin{tabular}{|c|c|c|c|c|c|c|c|c|c|c|c|c|c|}
\hline $\begin{array}{l}02019.100656 / 2 \\
017-12\end{array}$ & $\begin{array}{l}22 / 06 \\
/ 2017\end{array}$ & $\begin{array}{l}\text { Demanda Externa: } \\
\text { Ministério Público } \\
\text { Federal }\end{array}$ & $\begin{array}{l}\text { Ofício } \\
\text { no1112/2017/GAB/MP } \\
\text { F/PRM/GAR - } 1^{\circ} \text { of }\end{array}$ & 019.01 & \begin{tabular}{|l} 
Ministério Público \\
Federal - \\
Procuradoria da \\
República no \\
município de \\
Garanhuns
\end{tabular} & Federal & SIM & $\begin{array}{l}\text { Notícia de Fato } \\
\text { no- } \\
1.26 .005 .00008 \\
2 / 2017-37\end{array}$ & $\begin{array}{l}\text { Prestar } \\
\text { informações sobre } \\
\text { as queimadas na } \\
\text { Serra do Cumaty }\end{array}$ & NÃO & Águas Belas & SIM & $\begin{array}{l}\text { Queimadas; Serra do } \\
\text { Cumaty }\end{array}$ \\
\hline $\begin{array}{l}02019.100718 / 2 \\
017-88\end{array}$ & $\begin{array}{l}27 / 06 \\
12017\end{array}$ & $\begin{array}{l}\text { Demanda Externa: } \\
\text { Ministério Público } \\
\text { Federal }\end{array}$ & $\begin{array}{l}\text { Ref: Procedimento } \\
\text { Investigatório Criminal } \\
\mathrm{n}^{0} \\
1.26 .006 .000079 / 2017 \\
-11\end{array}$ & 019.01 & $\begin{array}{l}\text { MINISTÉRIO } \\
\text { PUBLICO } \\
\text { FEDERAL (MPF } \\
\text { JUÍZ DE } \\
\text { FORA/MG) }\end{array}$ & Federal & SIM & $\begin{array}{l}\text { Procedimento } \\
\text { Investigatório } \\
\text { Criminal } \mathrm{n}^{\circ} \\
1.26 .006 .00007 \\
9 / 2017-11\end{array}$ & $\begin{array}{l}\text { Apurar denúncia } \\
\text { de desmatamento } \\
\text { e extermínio de } \\
\text { animais silvestres } \\
\text { e construção de } \\
\text { barragens } \\
\text { irregulares em } \\
\text { APP (Mata } \\
\text { Atlântica) }\end{array}$ & NÃO & $\begin{array}{l}\text { Vicência, } \\
\text { Timbaúba e } \\
\text { Macaparana }\end{array}$ & NÃO & $\begin{array}{l}\text { Desmatamento; Mata } \\
\text { Atlântica; proximidade do } \\
\text { Pico do Mascarenhas; } \\
\text { Engenhos }\end{array}$ \\
\hline $\begin{array}{l}\text { 02019.100834/2 } \\
017-05\end{array}$ & $\begin{array}{l}05 / 07 \\
/ 2017\end{array}$ & $\begin{array}{l}\text { Demanda Externa: } \\
\text { Ministério Público } \\
\text { Federal }\end{array}$ & $\begin{array}{l}\text { Francisco Carneiro } \\
\text { Barreto Campelo }\end{array}$ & 019.01 & $\begin{array}{l}\text { PROCURADORIA } \\
\text { DA REPÚBLICA } \\
\text { POLO } \\
\text { SALGUEIRO/OUR } \\
\text { ICURI }\end{array}$ & Federal & SIM & $\begin{array}{l}\text { IC } n^{0} \\
1.26 .001 .00042 \\
6 / 2016-67\end{array}$ & $\begin{array}{l}\text { Manifestar-se } \\
\text { sobre imóvel na } \\
\text { APP do São } \\
\text { Francisco }\end{array}$ & NÃO & Petrolina & SIM & APP do Rio São Francisco \\
\hline $\begin{array}{l}\text { 02019.100835/2 } \\
017-41\end{array}$ & $\begin{array}{l}05 / 07 \\
12017\end{array}$ & $\begin{array}{l}\text { Demanda Externa: } \\
\text { Ministério Público } \\
\text { Federal }\end{array}$ & $\begin{array}{l}\text { INQUÉRITO CIVIL № } \\
1.26001 .000264 / 2015- \\
86\end{array}$ & 019.01 & $\begin{array}{l}\text { PROCURADORIA } \\
\text { DA REPÚBLICA } \\
\text { POLO } \\
\text { PETROLINA/JUA } \\
\text { ZEIRO }\end{array}$ & Federal & SIM & $\begin{array}{l}\text { IC } n^{0} \\
1.26001 .000264 \\
/ 2015-86\end{array}$ & $\begin{array}{l}\text { Informar sobre } \\
\text { PRAD ref. ao AI no } \\
\text { 9074144-E }\end{array}$ & SIM & Petrolina & SIM & Al no 9074144-E \\
\hline $\begin{array}{l}02019.100836 / 2 \\
017-96\end{array}$ & $\begin{array}{l}05 / 07 \\
/ 2017\end{array}$ & $\begin{array}{l}\text { Demanda Externa: } \\
\text { Ministério Público } \\
\text { Federal }\end{array}$ & $\begin{array}{l}\text { INQUERITO CIVIL № } \\
1.26001000282 / 2014- \\
87\end{array}$ & 019.01 & $\begin{array}{l}\text { MPF-Procuradoria } \\
\text { da Republica Polo } \\
\text { Petrolina/Juazeiro }\end{array}$ & Federal & SIM & $\begin{array}{l}\text { IC } n^{0} \\
1.26001000282 / \\
2014-87\end{array}$ & $\begin{array}{l}\text { Informar sobre os } \\
\text { processos dos Al } \\
n^{\circ} 9074152 \text { e } n^{\circ} \\
9074153\end{array}$ & SIM & Petrolina & SIM & Al no 9074152 e 9074153 \\
\hline $\begin{array}{l}02019.100998 / 2 \\
017-24\end{array}$ & $\begin{array}{l}14 / 07 \\
/ 2017\end{array}$ & $\begin{array}{l}\text { Gestão da } \\
\text { Informação: } \\
\text { Avaliação/Destina } \\
\text { ção de } \\
\text { Documentos }\end{array}$ & $\begin{array}{l}\text { OFICIO DE № 584- } \\
\text { 2017-PRM / Cabo -PE }\end{array}$ & 063.4a & $\begin{array}{l}\text { Ministério Público } \\
\text { Federal - } \\
\text { Procuradoria da } \\
\text { República - Polo } \\
\text { Cabo de Santo } \\
\text { Agostinho/Palmar } \\
\text { es - } 2^{\circ} \text { Ofício } \\
\text { (MPF) }\end{array}$ & Federal & SIM & $\begin{array}{l}\text { IC } n^{0} \\
1.26 .000 .00166 \\
0 / 2014-50\end{array}$ & $\begin{array}{l}\text { Informações sobre } \\
\text { ocupação irregular } \\
\text { de área de } \\
\text { mangue na Vila do } \\
\text { Casado }\end{array}$ & NÃO & Sirinhaém & SIM & $\begin{array}{l}\text { Ocupação irregular; } \\
\text { mangue; Vila do Casado }\end{array}$ \\
\hline $\begin{array}{l}\text { 02019.101055/2 } \\
017-19\end{array}$ & $\begin{array}{l}21 / 07 \\
/ 2017\end{array}$ & $\begin{array}{l}\text { Demanda Externa: } \\
\text { Ministério Público } \\
\text { Federal }\end{array}$ & $\begin{array}{l}\text { Procedimento } \\
\text { Preparatório no } \\
1.26 .000 .000389 / 2017 \\
-88\end{array}$ & 019.01 & $\begin{array}{l}\text { Ministério Público } \\
\text { Federal - } \\
\text { Procuradoria da } \\
\text { República em } \\
\text { Pernambuco }\end{array}$ & Federal & SIM & $\begin{array}{l}\text { Procedimento } \\
\text { Preparatório no } \\
1.26 .000 .00038 \\
9 / 2017-88\end{array}$ & $\begin{array}{l}\text { Vistoria em área } \\
\text { de invasão de } \\
\text { terra da União, às } \\
\text { margens da BR } \\
408\end{array}$ & NÃO & $\begin{array}{l}\text { São Lourenço } \\
\text { da Mata }\end{array}$ & SIM & Invasão em terra da União \\
\hline $\begin{array}{l}\text { 02019.101281/2 } \\
017-08\end{array}$ & $\begin{array}{l}203 / 08 \\
/ 2017\end{array}$ & $\begin{array}{l}\text { Demanda Externa: } \\
\text { Ministério Público } \\
\text { Federal }\end{array}$ & $\begin{array}{l}\text { OFÍCIO № } \\
\text { 1410/2017/GAB/MPF/ } \\
\text { PRM/GAR- } 1^{\circ} \text { OF }\end{array}$ & 019.01 & $\begin{array}{l}\text { Ministério Público } \\
\text { Federal - } \\
\text { Procuradoria da } \\
\text { República no } \\
\text { município de } \\
\text { Garanhuns }\end{array}$ & Federal & SIM & $\begin{array}{l}\text { Procedimento } \\
\text { Preparatório } \mathrm{n}^{\circ} \\
1.26 .005 .00010 \\
8 / 2017-47\end{array}$ & $\begin{array}{l}\text { Informar sobre } \\
\text { licenciamento da } \\
\text { Barragem do } \\
\text { Cajueiro }\end{array}$ & NÃO & Garanhuns & SIM & $\begin{array}{l}\text { Licenciamento ambiental; } \\
\text { Barragem do Cajueiro }\end{array}$ \\
\hline $\begin{array}{l}\text { 02019.101670/2 } \\
017-25\end{array}$ & $\begin{array}{l}31 / 08 \\
/ 2017\end{array}$ & $\begin{array}{l}\text { Demanda Externa: } \\
\text { Ministério Público } \\
\text { Federal }\end{array}$ & $\begin{array}{l}\text { OFí́CIO 4089/2017 - } \\
\text { MPF/PRPE/MSM }\end{array}$ & 019.01 & $\begin{array}{l}\text { MPF- } \\
\text { PROCURADORIA } \\
\text { DA REPÚBLICA } \\
\text { EM } \\
\text { PERNAMBUCO }\end{array}$ & Federal & SIM & $\begin{array}{l}\text { Autos } \mathrm{n}^{0} \\
1.26 .000 .00314 \\
4 / 2015-41\end{array}$ & $\begin{array}{l}\text { Esclarecimentos } \\
\text { sobre animais } \\
\text { abatidos em } \\
\text { decorrência da } \\
\text { queima da palha } \\
\text { de cana-de-açúcar }\end{array}$ & NÃO & $\begin{array}{l}\text { Paudalho; } \\
\text { Carpina }\end{array}$ & SIM & $\begin{array}{l}\text { Queimadas; cana-de- } \\
\text { açúcar; animais } \\
\text { ameaçados de extinção }\end{array}$ \\
\hline
\end{tabular}




\begin{tabular}{|c|c|c|c|c|c|c|c|c|c|c|c|c|c|}
\hline $\begin{array}{l}\text { 02019.101933/2 } \\
017-04\end{array}$ & $\begin{array}{l}14 / 09 \\
12017\end{array}$ & $\begin{array}{l}\text { Demanda Externa: } \\
\text { Ministério Público } \\
\text { Federal }\end{array}$ & $\begin{array}{l}\text { OFÍCIO № } \\
208 / 2017 / M P F / S G O / G \\
\text { ABI/AMSJ } \\
\text { REQUISIÇÃO DE } \\
\text { INFORMAÇÕES . PIC } \\
\text { № } \\
1.26 .004 .000105 / 2017 \\
-13\end{array}$ & 019.01 & $\begin{array}{l}\text { MPF/PROCURAD } \\
\text { ORIA DA } \\
\text { REPÚBLICA } \\
\text { POLO } \\
\text { SALGUEIRO - } \\
\text { OURICURI/PE }\end{array}$ & Federal & SIM & $\begin{array}{l}\text { PIC } n^{\circ} \\
1.26 .004 .00010 \\
5 / 2017-13\end{array}$ & $\begin{array}{l}\text { Informar sobre } \\
\text { licenciamento } \\
\text { para lavra de } \\
\text { minerais no Sítio } \\
S\end{array}$ & NÃO & Verdejante & SIM & $\begin{array}{l}\text { Licenciamento ambiental; } \\
\text { mineração; Sítios S }\end{array}$ \\
\hline $\begin{array}{l}\text { 02019.102065/2 } \\
017-71\end{array}$ & $\begin{array}{l}21 / 09 \\
/ 2017\end{array}$ & $\begin{array}{l}\text { Demanda Externa: } \\
\text { Ministério Público } \\
\text { Estadual }\end{array}$ & $\begin{array}{l}\text { OFíCIO № 267/2017 - } \\
\text { PJT }\end{array}$ & 019.01 & $\begin{array}{l}\text { MPPE - } \\
\text { PROMOTORIA } \\
\text { DE JUSTIÇA DA } \\
\text { COMARCA DE } \\
\text { TRINDADE-PE }\end{array}$ & Estadual & SIM & $\begin{array}{l}\text { IC no } 001 / 2016 \\
2016 / 2435413\end{array}$ & $\begin{array}{l}\text { Informar sobre o } \\
\text { problema com } \\
\text { cercas divisórias } \\
\text { da faixa de } \\
\text { domínio da } \\
\text { Ferrovia } \\
\text { Transnordestina, } \\
\text { especificamente } \\
\text { no Sítio Abóbora }\end{array}$ & SIM & Trindade & SIM & $\begin{array}{l}\text { Licenciamento ambiental; } \\
\text { Ferrovia Transnordestina; } \\
\text { Comunidade Sítio } \\
\text { Abóbora }\end{array}$ \\
\hline $\begin{array}{l}\text { 02019.102338/2 } \\
017-88\end{array}$ & $\begin{array}{l}11 / 10 \\
/ 2017\end{array}$ & $\begin{array}{l}\text { Demanda Externa: } \\
\text { Ministério Público } \\
\text { Federal }\end{array}$ & $\begin{array}{l}\text { OF; 980-2017-PRM- } \\
\text { APURAR NOTÍCIA DE } \\
\text { POSSIVEIS } \\
\text { IRREGULARIDADES } \\
\text { NO } \\
\text { ASSENTAMENTO. } \\
\text { EM AMARAJI -PE }\end{array}$ & 019.01 & $\begin{array}{l}\text { Ministério Público } \\
\text { Federal - } \\
\text { Procuradoria da } \\
\text { República - Polo } \\
\text { Cabo de Santo } \\
\text { Agostinho/Palmar } \\
\text { es }-2^{\circ} \text { Ofício } \\
\text { (MPF) }\end{array}$ & Federal & SIM & $\begin{array}{l}\text { IC no } \\
1.26 .00 .003213 / \\
2015-16\end{array}$ & $\begin{array}{l}\text { Apurar denúncia } \\
\text { de invasão e } \\
\text { exploração de } \\
\text { área de reserva } \\
\text { legal no } \\
\text { assentamento } \\
\text { "Não Pensei". }\end{array}$ & NÃO & Amaraji & NÃO & $\begin{array}{l}\text { Reserva legal; } \\
\text { assentamento "Não } \\
\text { Pensei" }\end{array}$ \\
\hline $\begin{array}{l}02019.102339 / 2 \\
017-22\end{array}$ & $\begin{array}{l}11 / 10 \\
/ 2017\end{array}$ & $\begin{array}{l}\text { Demanda Externa: } \\
\text { Ministério Público } \\
\text { Federal }\end{array}$ & $\begin{array}{l}\text { OFICIO 1889-2017- } \\
\text { MPF/ PRM- } \\
\text { INQUÉRITO CIVIL - } \\
\text { PARA APURAR } \\
\text { CAPTAÇÃO ILEGAL } \\
\text { DE ÁGUA EM } \\
\text { GARANHUNS }\end{array}$ & 019.01 & $\begin{array}{l}\text { Ministério Público } \\
\text { Federal - } \\
\text { Procuradoria da } \\
\text { República no } \\
\text { município de } \\
\text { Garanhuns }\end{array}$ & Federal & SIM & $\begin{array}{l}\text { IC } n^{0} \\
1.26 .005 .00026 \\
5 / 2016-71\end{array}$ & $\begin{array}{l}\text { Apurar denúncia } \\
\text { de captação ilegal } \\
\text { de água pela } \\
\text { Prefeitura de } \\
\text { Garanhuns/PE, na } \\
\text { localidade de } \\
\text { Serra Branca }\end{array}$ & NÃO & Garanhuns & SIM & $\begin{array}{l}\text { Desmatamento; captação } \\
\text { de água; Serra Branca }\end{array}$ \\
\hline $\begin{array}{l}\text { 02019.102537/2 } \\
017-96\end{array}$ & $\begin{array}{l}20 / 10 \\
12017\end{array}$ & $\begin{array}{l}\text { Demanda Externa: } \\
\text { Ministério Público } \\
\text { Federal }\end{array}$ & $\begin{array}{l}\text { OFICIO, No 792-2017- } \\
\text { PR-PTAJZO, } \\
\text { INQUERITO CIVIL, } \\
110.2010 .80, \text { PEDIDO } \\
\text { P/ APURAR } \\
\text { POSSIVEL } \\
\text { REGULARIDADE }\end{array}$ & 019.01 & $\begin{array}{l}\text { MINISTERIO } \\
\text { PÚBLICO } \\
\text { FEDERAL POLO } \\
\text { EM PETROLINA } \\
\text { JUAZEIRO }\end{array}$ & Federal & SIM & $\begin{array}{l}\text { IC } n^{0} \\
1.26 .001 .00011 \\
0 / 2010-80\end{array}$ & $\begin{array}{l}\text { Informar sobre } \\
\text { regularidade da } \\
\text { Chácara S , na } \\
\text { APP do Rio São } \\
\text { Francisco }\end{array}$ & NÃO & Petrolina & SIM & $\begin{array}{l}\text { APP do Rio São } \\
\text { Francisco; Chácara S }\end{array}$ \\
\hline $\begin{array}{l}\text { 02019.102625/2 } \\
017-98\end{array}$ & $\begin{array}{l}26 / 10 \\
/ 2017\end{array}$ & $\begin{array}{l}\text { Demanda Externa: } \\
\text { Ministério Público } \\
\text { Federal }\end{array}$ & $\begin{array}{l}\text { OF: 1092-2017-PRM- } \\
\text { Cabo/PE- REF: } \\
\text { Inquérito Civil } \\
1.26 .008 .000199- \\
2017--11\end{array}$ & 019.01 & $\begin{array}{l}\text { Ministério Público } \\
\text { Federal - } \\
\text { Procuradoria da } \\
\text { República em } \\
\text { Pernambuco }\end{array}$ & Federal & SIM & $\begin{array}{l}\text { IC } n^{\circ} \\
1.26 .008 .00019 \\
9 / 2017-911\end{array}$ & $\begin{array}{l}\text { Informar sobre } \\
\text { licenciamento } \\
\text { ambiental da } \\
\text { dragagem do } \\
\text { Estaleiro Promar }\end{array}$ & NÃO & $\begin{array}{l}\text { Cabo de } \\
\text { Santo } \\
\text { Agostinho }\end{array}$ & SIM & $\begin{array}{l}\text { Licenciamento ambiental; } \\
\text { Suape, Estaleiro Promar }\end{array}$ \\
\hline $\begin{array}{l}02019.102627 / 2 \\
017-87\end{array}$ & $\begin{array}{l}27 / 10 \\
/ 2017\end{array}$ & $\begin{array}{l}\text { Demanda Externa: } \\
\text { Ministério Público } \\
\text { Estadual }\end{array}$ & $\begin{array}{l}\text { OF; 345-2017- MA, } \\
\text { Ref: REQUESITO, } \\
\text { pedido de vistoria no } \\
\text { corpo Hidrico ( ETE ) } \\
\text { Relatório técnico. }\end{array}$ & 019.01 & $\begin{array}{l}\text { MINISTERIO } \\
\text { PUBLICO DO } \\
\text { ESTADO DE } \\
\text { PERNAMBUCO } \\
\text { (MP/PE) }\end{array}$ & Estadual & SIM & $\begin{array}{l}\text { IC no 03/2013 - } \\
\text { Autos } \\
2013 / 1006247\end{array}$ & $\begin{array}{l}\text { Realizar vistoria } \\
\text { em ponto de } \\
\text { lançamento de } \\
\text { ETE }\end{array}$ & NÃO & $\begin{array}{l}\text { Cabo de } \\
\text { Santo } \\
\text { Agostinho }\end{array}$ & SIM & $\begin{array}{l}\text { Lançamento de efluentes; } \\
\text { Compesa }\end{array}$ \\
\hline $\begin{array}{l}02019.102734 / 2 \\
017-13\end{array}$ & $\begin{array}{l}07 / 11 \\
/ 2017\end{array}$ & $\begin{array}{l}\text { Demanda Externa: } \\
\text { Ministério Público } \\
\text { Estadual }\end{array}$ & $\begin{array}{l}\text { OF; 200-2017-PJ/SBU. } \\
\text { NOTICIA DE FATO } \\
\text { 2017-2791318, REF; } \\
\text { MAUS- TRATOS NO } \\
\text { CANIL }\end{array}$ & 019.01 & $\begin{array}{l}\text { MINISTERIO } \\
\text { PUBLICO DO } \\
\text { ESTADO DE } \\
\text { PERNAMBUCO } \\
\text { (MP/PE) }\end{array}$ & Estadual & SIM & $\begin{array}{l}\text { Auto } \mathrm{n}^{0} \\
2017.2791318\end{array}$ & $\begin{array}{l}\text { Apurar denúncia } \\
\text { de maus-tratos no } \\
\text { Canil Municipal de } \\
\text { São Bento do } \\
\text { Uma }\end{array}$ & NÃO & $\begin{array}{l}\text { São Bento do } \\
\text { Uma }\end{array}$ & SIM & $\begin{array}{l}\text { Maus-tratos a animais } \\
\text { domésticos; canil } \\
\text { municipal de São Bento do } \\
\text { Uma }\end{array}$ \\
\hline
\end{tabular}




\begin{tabular}{|c|c|c|c|c|c|c|c|c|c|c|c|c|c|}
\hline $\begin{array}{l}02019.102783 / 2 \\
017-48\end{array}$ & $\begin{array}{l}09 / 11 \\
/ 2017\end{array}$ & $\begin{array}{l}\text { Demanda Externa: } \\
\text { Ministério Público } \\
\text { Estadual }\end{array}$ & $\begin{array}{l}\text { OF; 123-2017-PJV, } \\
\text { Apurar a existência de } \\
\text { dano Ambiental da } \\
\text { fazenda S- da } \\
\mathrm{Sr}^{\mathrm{a}} \mathrm{Fra}\end{array}$ & 019.01 & $\begin{array}{l}\text { MINISTERIO } \\
\text { PUBLICO DO } \\
\text { ESTADO DE } \\
\text { PERNAMBUCO } \\
\text { (MP/PE) }\end{array}$ & Estadual & SIM & IC no 03/2017 & $\begin{array}{l}\text { Realizar vistoria } \\
\text { na Fazenda } \\
\text { Salinas, para } \\
\text { verificar existência } \\
\text { de dano ambiental } \\
\text { decorrente de } \\
\text { lavra irregular }\end{array}$ & NÃO & Verdejante & SIM & Mineração; Fazenda S \\
\hline $\begin{array}{l}02019.102979 / 2 \\
017-32\end{array}$ & $\begin{array}{l}27 / 11 \\
/ 2017\end{array}$ & $\begin{array}{l}\text { Demanda Externa: } \\
\text { Ministério Público } \\
\text { Federal }\end{array}$ & $\begin{array}{l}\text { OFICIO,S/N -2019- } \\
\text { GAB- LR- PRPE/MPE, } \\
45619-2017 \text { - NOTÍCIA } \\
\text { DE FATO, REF; } \\
\text { CRIME AMBIENTAL, }\end{array}$ & 019.01 & $\begin{array}{l}\text { Ministério Público } \\
\text { Federal - } \\
\text { Procuradoria da } \\
\text { República em } \\
\text { Pernambuco }\end{array}$ & Federal & SIM & $\begin{array}{l}\text { Notícia de Fato } \\
\text { no }^{\circ} \\
1.26 .000 .00321 \\
3 / 2017-88\end{array}$ & $\begin{array}{l}\text { Apurar denúncia } \\
\text { de de dano ao } \\
\text { Parque dos } \\
\text { Manguezais pelo } \\
\text { empreendimento } \\
\text { Le Parc Boa } \\
\text { Viagem }\end{array}$ & NÃO & Recife & SIM & $\begin{array}{l}\text { Parque dos Manguezais; } \\
\text { Le Parc Boa Viagem }\end{array}$ \\
\hline $\begin{array}{l}\text { 02019.103069/2 } \\
017-77\end{array}$ & $\begin{array}{l}04 / 12 \\
/ 2017\end{array}$ & $\begin{array}{l}\text { Demanda Externa: } \\
\text { Ministério Público } \\
\text { Federal }\end{array}$ & $\begin{array}{l}\text { OFICIO 623-2017- } \\
\text { ENCAMINHO CÓPIA } \\
\text { DA DENÚNCIA } 23514 \\
\text { RECIBIDA PELO } \\
\text { MPPE, }\end{array}$ & 019.01 & $\begin{array}{l}\text { MINISTERIO } \\
\text { PUBLICO DO } \\
\text { ESTADO DE } \\
\text { PERNAMBUCO } \\
\text { (MP/PE) }\end{array}$ & Estadual & SIM & $\begin{array}{l}\text { Denúncia no } \\
23514\end{array}$ & $\begin{array}{l}\text { Apurar denúncia } \\
\text { de extração } \\
\text { irregular de areia } \\
\text { e devastação da } \\
\text { Mata Atlântica }\end{array}$ & NÃO & Abreu e Lima & SIM & Mineração; Mata Atlântica \\
\hline $\begin{array}{l}02019.103312 / 2 \\
017-57\end{array}$ & $\begin{array}{l}13 / 12 \\
/ 2017\end{array}$ & $\begin{array}{l}\text { Demanda Externa: } \\
\text { Ministério Público } \\
\text { Estadual }\end{array}$ & $\begin{array}{l}\text { Oficio; } 376-2017-\text { Ref; } \\
\text { TCO Art } 29 \text { da lei } \\
\text { 9.605-98 }\end{array}$ & 019.01 & $\begin{array}{l}\text { MINISTERIO } \\
\text { PUBLICO DO } \\
\text { ESTADO DE } \\
\text { PERNAMBUCO } \\
\text { (MP/PE) }\end{array}$ & Estadual & SIM & $\begin{array}{l}\text { Arquimedes: } \\
8491635\end{array}$ & $\begin{array}{l}\text { Adotar } \\
\text { providências } \\
\text { sobre apreensão } \\
\text { de cinco pássaros } \\
\text { feita pela Polícia } \\
\text { Civil }\end{array}$ & NÃO & Olinda & NÃO & Fauna \\
\hline $\begin{array}{l}02019.103381 / 2 \\
017-61\end{array}$ & $\begin{array}{l}20 / 12 \\
/ 2017\end{array}$ & $\begin{array}{l}\text { Fiscalização } \\
\text { Ambiental: } \\
\text { Apuração de } \\
\text { Infrações } \\
\text { Ambientais }\end{array}$ & $\begin{array}{l}\text { AUTO DE INFRAÇÃO } \\
\text { 9168935/E }\end{array}$ & 511 & $\begin{array}{l}\text { AAR } \\
\text { (CPF } 10\end{array}$ & Federal & NÂO & $\begin{array}{l}\text { Noticia de Falo } \\
n^{\circ}= \\
1.26 .000 .00182 \\
8 / 2018-51\end{array}$ & $\begin{array}{l}\text { Prestar } \\
\text { esclarecimentos } \\
\text { sobre a infração } \\
\text { registrada no Al no } \\
\text { 9168935-E }\end{array}$ & SIM & Igarassu & SIM & Al nº 9168935-E; Sispass \\
\hline
\end{tabular}

CLASSIFICAÇÃO POR ASSUNTOS

019.01 - INFORMAÇÕES SOBRE O ÓRGÃO (inclusive Pedidos de Informações sobre as Funções e Atividades do Órgão e os Serviços que presta)

063.4a - CLASSIFICAÇÃO E ARQUIVAMENTO

100 - RECURSOS FLORESTAIS E FLORÍSTICOS

100.01 - NORMAS

110.5 - RECUPERAÇÃO DE ÁREA DEGRADADA

413.1 - LICENÇA PRÉVIA

510 - FISCALIZACÃO AMBIENTAL (ORDENAR POR: FAUNA, FLORA, PESCA, POLUIČ̃̃O, DEGRADAÇÃO AMBIENTAL, AEROPORTUÁRIA/ PORTUÁRIA, ACESSO AO PATRIMÔNIO GENÉTICO, ÁREAS PROTEGIDAS)

511 - INSTRUMENTOS DE FISCALIZAÇÃO (ORDEM DE FISCALIZAC̄̃̃O, LEVANTAMENTO DE PRODUTO FLORESTAL, AUTO DE INFRAÇÃO, TERMO DE APREENSÃO, DEPỎSITO, DESTINAÇÃO ETC, NOTIFICAÇÃO, COMUNICAÇÃO DE CRIME, RELLATÓRIO DE FISCALIZAÇÃO).

812.42 - INVENTÁRIO DE RESÍDUOS SÓLIDOS INDUSTRIAIS

995 - PEDIDOS, OFERECIMENTOS E INFORMAÇÕES DIVERSAS 


\section{ANEXO A - SISTEMAS DE INFORMAÇÃO DO IBAMA}

Relação dos sistemas implantados ou em desenvolvimento pelo lbama, conforme Plano Diretor de Tecnologia da Informação e Comunicações (PDTIC) do Ibama 2017-2019 (IBAMA, 2018, p. 44-47):

\begin{tabular}{|c|c|c|c|}
\hline \multicolumn{4}{|c|}{ Sistemas legados (já desenvolvidos) } \\
\hline $\mathbf{N}^{o}$ & Sigla & Descrição do Sistema & Área \\
\hline 1 & ADA & Sistema do Ato Declaratório Ambiental. & \multirow{8}{*}{ DBFLO } \\
\hline 2 & CITES & $\begin{array}{l}\text { Sistema de gerenciamento de requerimentos e licenças de } \\
\text { importação, exportação e reexportação de produtos e subprodutos } \\
\text { da fauna e flora brasileira ameaçada ou não de extinção em } \\
\text { atendimento à Convenção Internacional. (Inclui o módulo de } \\
\text { Cadastro de Coleções Biológicas - CCBIO). }\end{array}$ & \\
\hline 3 & DOF & $\begin{array}{l}\text { Sistema de Monitoramento e Controle do transporte de produtos e } \\
\text { subprodutos florestais vinculado ao Documento de Origem } \\
\text { Florestal. }\end{array}$ & \\
\hline 4 & MOTOSSERRAS (LPU) & Sistema de Licenciamento do Porte e Uso de Motosserra. & \\
\hline 5 & SISFAUNA & Sistema Nacional de Gestão de Fauna. & \\
\hline 6 & SISPASS & Sistema de Gestão dos Criadores de Passeriformes. & \\
\hline 7 & SISTAXON & Sistema de Taxonomia. & \\
\hline 8 & SISPROF & Sistema de Produtos Florestais. & \\
\hline 9 & $\begin{array}{l}\text { SICAFI- } \\
\text { FISCALIZAÇÃO }\end{array}$ & $\begin{array}{l}\text { Sistema Integrado de Cadastro, Arrecadação e Fiscalização. Módulo } \\
\text { Fiscalização e Destinação de Bens Apreendidos. }\end{array}$ & \multirow[b]{3}{*}{ DIPRO } \\
\hline 10 & AI-E & $\begin{array}{l}\text { Sistema de Auto de Infração eletrônico } \\
\text { (parte integrante do SICAFI-FISCALIZAÇÃO). }\end{array}$ & \\
\hline 11 & $\begin{array}{l}\text { AUTORIZAÇÃO } \\
\text { AMBIENTAL PARA O } \\
\text { TRANSPORTE } \\
\text { INTERESTADUAL DE } \\
\text { PRODUTOS } \\
\text { PERIGOSOS } \\
\end{array}$ & $\begin{array}{l}\text { Autorização Ambiental para o Transporte Interestadual de Produtos } \\
\text { Perigosos. }\end{array}$ & \\
\hline 12 & CTF/AIDA & $\begin{array}{l}\text { Sistema Cadastro Técnico Federal de Atividades e Instrumentos de } \\
\text { Defesa Ambiental. }\end{array}$ & \multirow[t]{4}{*}{ DIQUA } \\
\hline 13 & CTF/APP & $\begin{array}{l}\text { Sistema Cadastro Técnico Federal de Atividades Potencialmente } \\
\text { Poluidoras e Utilizadoras de Recursos Ambientais. }\end{array}$ & \\
\hline 14 & RAPP & Relatório Anual de Atividades Potencialmente Poluidoras. & \\
\hline 15 & $\begin{array}{l}\text { CERTIFICADO DE } \\
\text { REGULARIDADE }\end{array}$ & Certificado de Regularidade. & \\
\hline
\end{tabular}




\begin{tabular}{|c|c|c|c|}
\hline 16 & $\begin{array}{l}\text { PROTOCOLO DE } \\
\text { MONTREAL }\end{array}$ & Sistema Protocolo de Montreal. & \\
\hline 17 & OLEO LUBRIFICANTE & $\begin{array}{l}\text { Sistema de acompanhamento e controle da destinação de óleo } \\
\text { lubrificante (Rel CONAMA 362/05). }\end{array}$ & \\
\hline 18 & PNEUMATICO & $\begin{array}{l}\text { Sistema de controle da importação, fabricação e da destinação final } \\
\text { dos pneumáticos (Rel. CONAMA 416/09). }\end{array}$ & \\
\hline 19 & $\begin{array}{l}\text { SISTEMÁDE } \\
\text { AGROTÓXICOS }\end{array}$ & $\begin{array}{l}\text { Sistema composto por: } \\
\text { PPA - Controle do requerimento de acompanhamento do potencial } \\
\text { de periculosidade ambiental. } \\
\text { Relatórios de Comercialização - Controle da Produção, Importação, } \\
\text { Exportação e da Comercialização de Produtos Agrotóxicos. }\end{array}$ & \\
\hline 20 & SIETRE & $\begin{array}{l}\text { Sistema de controle da Importação, exportação e trânsito de } \\
\text { resíduos (ainda não se encontra em ambiente de produção). }\end{array}$ & \\
\hline 21 & SISRET & Sistema Registro Especial Temporário de Agrotóxicos. & \\
\hline 22 & SISRET V2 & $\begin{array}{l}\text { Sistema Registro Especial Temporário de Agrotóxicos V2 (ainda } \\
\text { não se encontra em ambiente de produção). }\end{array}$ & \\
\hline 23 & INFOSERV/PROCONV & $\begin{array}{l}\text { Sistema de controle dos veículos que serão comercializados no país } \\
\text { no que diz respeito a emissão de gases poluentes. }\end{array}$ & \\
\hline 24 & MERCÚRIO & Sistema Mercúrio Metálico. & \\
\hline 25 & SISPAT & Sistema de Gerenciamento de Informações Patrimoniais. & \multirow{8}{*}{ DIPLAN } \\
\hline 26 & SISPONTO & Sistema de Ponto do Ibama. & \\
\hline 27 & SISMAT & Sistema de Material. & \\
\hline 28 & $\begin{array}{l}\text { SICAFI- } \\
\text { ARRECADAÇÃO }\end{array}$ & $\begin{array}{l}\text { Sistema Integrado de Cadastro, Arrecadação e Fiscalização. } \\
\text { Módulo Arrecadação. }\end{array}$ & \\
\hline 29 & SICAFI-CAMARA & $\begin{array}{l}\text { Sistema Integrado de Cadastro, Arrecadação e Fiscalização. } \\
\text { Módulo Câmara. }\end{array}$ & \\
\hline 30 & SICAFI JURIDICO & $\begin{array}{l}\text { Sistema Integrado de Cadastro, Arrecadação e Fiscalização. } \\
\text { Funcionalidade da Lei 12.996/14 (Parcelamento/Antecipação). }\end{array}$ & \\
\hline 31 & SIAC & Sistema de Acompanhamento de Contratos. & \\
\hline 32 & SIGER & Sistema de Informações Gerenciais e Segurança de Acesso. & \\
\hline 33 & SISLIC & Sistema Informatizado de Licenciamento Ambiental. & DILIC \\
\hline 34 & SISLIV & Sistema Linha Verde de Ouvidoria. & \multirow{2}{*}{$\begin{array}{l}\text { AUDIT/ } \\
\text { COUV }\end{array}$} \\
\hline 35 & $\begin{array}{l}\text { SICAFI- } \\
\text { ATENDIMENTO }\end{array}$ & $\begin{array}{l}\text { Sistema Integrado de Cadastro, Arrecadação e Fiscalização. } \\
\text { Módulo Atendimento. }\end{array}$ & \\
\hline 36 & Harpia & Sistema de Catálogo de imagens de satélite Harpia. & \multirow{5}{*}{ CENIMA } \\
\hline 37 & $3 \mathrm{D}$ & Sistema de Detecção Desmatamento Domínio. & \\
\hline 38 & Painel Desmate & Painel de Situação do Desmatamento. & \\
\hline 39 & SISOP & Sistema de Gerenciamento de Operações. & \\
\hline 40 & DOC.IBAMA & Sistema de Gestão Documental no Ibama. & \\
\hline 41 & FORMDIN & Framework para desenvolvimento em PHP. & \multirow[t]{2}{*}{ CGTI } \\
\hline 42 & FASIS & Sistema de Controle de Acesso para sistemas PHP. & \\
\hline
\end{tabular}




\begin{tabular}{|l|l|l|c|}
\hline 43 & SERVIÇOS IBAMA & $\begin{array}{l}\text { Agregador de serviços e aplicações do Ibama via Internet para o } \\
\text { público externo. }\end{array}$ & \\
\hline 44 & $\begin{array}{l}\text { MÓDULO DE } \\
\text { SEGURANÇA }\end{array}$ & $\begin{array}{l}\text { Módulo de controle de menus, perfis e usuários de sistemas legados } \\
\text { (PHP). Sistema anterior ao FASIS e ao SCA. É utilizado pelo } \\
\text { Sicafi, Cites, Sislic, Sismat, Sispass, Sisbio, SNA, DOF e Sistaxon. }\end{array}$ & \\
\hline 45 & CONTENCIOSO & Sistema eletrônico para Acompanhamento de Precatórios. & PFE \\
\hline 46 & SISCOPDI & Sistema Eletrônico de Controle de Processos Disciplinares. & COGER \\
\hline
\end{tabular}

\begin{tabular}{|c|c|c|c|}
\hline \multicolumn{4}{|c|}{ Sistemas em desenvolvimento ou recém-desenvolvidos } \\
\hline $\mathbf{N}^{\mathbf{o}}$ & Sigla & Descrição do Sistema & Área \\
\hline 1 & SINAFLOR & Sistema Nacional de Controle da Origem dos Produtos Florestais. & \multirow{3}{*}{ DBFLO } \\
\hline 2 & GET & Guia Eletrônica de Transporte de Peixes. & \\
\hline 3 & SIMAF & $\begin{array}{l}\text { Sistema de Manejo de Fauna em Vida Livre (a ser adaptado/integrado } \\
\text { - desenvolvido pela Embrapa). }\end{array}$ & \\
\hline 4 & SISFOGO & Sistema Nacional de Informações sobre Fogo. & \multirow{3}{*}{ DIPRO } \\
\hline 5 & SNTPP & Sistema Nacional de Transporte Produtos Perigosos. & \\
\hline 6 & SIEMA & Sistema Nacional de Emergências Ambientais. & \\
\hline 7 & SISREM & $\begin{array}{l}\text { Sistema para Requerimento de Registro e Avaliação de Produtos } \\
\text { Remediadores. }\end{array}$ & \multirow{2}{*}{ DIQUA } \\
\hline 8 & $\begin{array}{l}\text { PROTOCOLO DE } \\
\text { MONTREAL V2 }\end{array}$ & Sistema Protocolo de Montreal V2. & \\
\hline 9 & SLE & $\begin{array}{l}\text { Sistema de Leilão Eletrônico (a ser adaptado/integrado - desenvolvido } \\
\text { pelo Ministério da Fazenda). }\end{array}$ & \multirow{4}{*}{ DIPLAN } \\
\hline 10 & SEI! & Sistema Eletrônico de Informações. & \\
\hline 11 & SIADI & $\begin{array}{l}\text { Sistema de Avaliação de Desempenho Individual (a ser adaptado/ } \\
\text { integrado - desenvolvido pelo Datasus). }\end{array}$ & \\
\hline 12 & SISPAT V2 & Sistema de Gerenciamento de Informações Patrimoniais V2. & \\
\hline 13 & SIGA & Sistema Integrado de Gestão Ambiental. & DILIC \\
\hline 14 & SISLIV V2 & Sistema Linha Verde de Ouvidoria V2. & $\begin{array}{l}\text { AUDIT/ } \\
\text { COUV }\end{array}$ \\
\hline 15 & SCA & Sistema de Controle de Acesso para sistemas JAVA. & CGTI \\
\hline
\end{tabular}




\begin{tabular}{|c|c|c|c|}
\hline \multicolumn{4}{|c|}{ Novos Sistemas } \\
\hline $\mathbf{N}^{\mathbf{o}}$ & Sigla & Descrição do Sistema & Área \\
\hline 1 & SISFAUNA V2 & Sistema Nacional de Gestão de Fauna V2. & \multirow[t]{2}{*}{ DBFLO } \\
\hline 2 & DOP & Documento de Origem do Pescado. & \\
\hline 3 & ESTATPESCA & Sistema de Estatística de Pesca. & \\
\hline 4 & $\begin{array}{l}\text { SISTEMA DE } \\
\text { FISCALIZAÇÃO } \\
\text { AMBIENTAL }\end{array}$ & $\begin{array}{l}\text { Sistema que comporta todo macroprocesso da fiscalização ambiental, } \\
\text { inteligência, sistema de informações geográficas, incluindo } \\
\text { ferramenta intuitiva para análise cronológica da paisagem através de } \\
\text { imagens de satélite e ferramenta de cadastro e acompanhamento de } \\
\text { alvos de Ilícitos ambientais. }\end{array}$ & \multirow[t]{2}{*}{ DIPRO } \\
\hline 5 & SISNÓLEO & $\begin{array}{l}\text { Necessidade de atendimento ao Decreto do 8.127/2013- } \\
\text { monitoramento de derrames de óleo no mar. }\end{array}$ & \\
\hline 6 & SISAGRO & Novo sistema de Avaliação e Controle de Produtos Agrotóxicos. & \multirow{3}{*}{ DIQUA } \\
\hline 7 & CNORP & $\begin{array}{l}\text { Cadastro Nacional de Operadores de Resíduos Perigosos. } \\
\text { Atender ao determinado na Política Nacional de Resíduos Sólidos } \\
\text { criado pela a Lei no } 12.305 \text {, de } 2 \text { de agosto de } 2010 .\end{array}$ & \\
\hline 8 & SELO-RUIDO & $\begin{array}{l}\text { Sistema para o processo de emissão da Autorização para uso do Selo } \\
\text { Ruído. }\end{array}$ & \\
\hline 9 & $\begin{array}{l}\text { SISTEMA DE } \\
\text { ARRECADAÇÃO }\end{array}$ & Novo sistema de Arrecadação do Ibama. & \multirow{3}{*}{ DIPLAN } \\
\hline 10 & SCMA & Sistema de Conversão de Multas Ambientais. & \\
\hline 11 & $\begin{array}{l}\text { CONTROLE DE } \\
\text { PROCESSOS PARA } \\
\text { COBRANÇAS E TCE }\end{array}$ & $\begin{array}{l}\text { Sistema para Controle de Processo da Unidade, necessário para } \\
\text { controle de cobrança e de Tomadas de Contas Especiais (TCE). }\end{array}$ & \\
\hline 12 & $\begin{array}{l}\text { SISTEMA DE } \\
\text { AUDITORIA }\end{array}$ & $\begin{array}{l}\text { Sistema informatizado capaz de gerar relatórios gerenciais que } \\
\text { auxiliarão no controlar das atividades de auditoria, entre elas, } \\
\text { acompanhar o atendimento das recomendações emitidas pela } \\
\text { Auditoria Interna do Ibama, acompanhar o atendimento das demandas } \\
\text { dos órgãos de controle, monitorar os prazos desses atendimentos. }\end{array}$ & AUDIT \\
\hline 13 & $\begin{array}{l}\text { SISTEMA DE } \\
\text { GERENCIAMENTO } \\
\text { DA CAPACITAÇÃO } \\
\text { DOS SERVIDORES }\end{array}$ & $\begin{array}{l}\text { Promover o gerenciamento e a transparência da capacitação dos } \\
\text { servidores, tendo em vista a relação entre capacitação e promoção } \\
\text { individual. Disponibilizando certificados, informando quantidade de } \\
\text { horas, cursos disponíveis, cursos planejados, etc. }\end{array}$ & CEDUC \\
\hline 14 & $\begin{array}{l}\text { PAINEL DE } \\
\text { INFORMAÇÕES } \\
\text { AMBIENTAIS DO } \\
\text { IBAMA }\end{array}$ & $\begin{array}{l}\text { Painel de Informações Ambientais do Ibama, que reunirá informações } \\
\text { dos diversos sistemas finalísticos do Ibama em um só lugar. }\end{array}$ & CGTI \\
\hline 15 & $\begin{array}{l}\text { SISTEMA PARA A } \\
\text { ASPAR }\end{array}$ & $\begin{array}{l}\text { Necessidade de troca de informações com os órgãos que possuem } \\
\text { uma assessoria parlamentar. }\end{array}$ & \multirow[b]{3}{*}{ PRESI } \\
\hline 16 & $\begin{array}{l}\text { SISTEMA PARA } \\
\text { GABINETE }\end{array}$ & Acompanhamento de prazo documental. & \\
\hline 17 & $\begin{array}{l}\text { Sistema para } \\
\text { alimentação e consulta } \\
\text { dos resultados de } \\
\text { julgamentos de autos } \\
\text { de infração e de } \\
\text { editais de notificação } \\
\text { no site do Ibama. }\end{array}$ & $\begin{array}{l}\text { Criar o sistema para a NUIP que deverá organizar os processos e } \\
\text { alimentar a consulta dos autos de infração e editais de notificação no } \\
\text { site do Ibama, facilitando o trabalho dos servidores e permitindo a } \\
\text { consulta a nomes e editais de forma mais rápida e transparente. }\end{array}$ & \\
\hline
\end{tabular}


Sistemas de outros órgãos/entidades manutenidos pelo Ibama

\begin{tabular}{|c|c|c|c|c|}
\hline \multicolumn{5}{|c|}{ Sistemas de outros órgãos/entidades manutenidos pelo Ibama } \\
\hline $\mathbf{N}^{o}$ & Sigla & Descrição do Sistema & $\begin{array}{c}\text { Contato } \\
\text { no } \\
\text { Ibama }\end{array}$ & $\begin{array}{c}\text { Órgão/ } \\
\text { Entidade } \\
\text { responsável }\end{array}$ \\
\hline 1 & SISQUELÔNIOS & Sistema de Informação e Gestão dos Quelônios Amazônicos. & DBFLO & ICMIBIO \\
\hline 2 & SNA & $\begin{array}{l}\text { O Sistema Nacional de Anilhamento de Aves Migratórias } \\
\text { envolve a coordenação e controle em nível nacional dos } \\
\text { seguintes procedimentos: Credenciamento dos anilhadores } \\
\text { (registro); Análise dos projetos de pesquisa e concessão das } \\
\text { Autorizações de Anilhamento; Controle e distribuição das } \\
\text { anilhas; Processamento dos dados de anilhamento; } \\
\text { Recebimento e processamento das informações relativas ao } \\
\text { encontro de uma ave anilhada (recuperação). } \\
\text { Observação: Este sistema é utilizado pela CGM.AVE do } \\
\text { ICMBIO e possui a Cocfp/Dbflo como ponto focal no Ibama. }\end{array}$ & DBFLO & ICMIBIO \\
\hline 3 & SISBIO & $\begin{array}{l}\text { Sistema de Autorização e Informação em Biodiversidade. } \\
\text { Permite pesquisadoses a solicitarem autorizações para coleta } \\
\text { de material biológico e para a realização de pesquisa em } \\
\text { unidades de conservação federais e cavernas. } \\
\text { Observação: Este sistema é utilizado pelo ICMBIO e possui a } \\
\text { Corad/Dbflo como ponto focal no Ibama. }\end{array}$ & DBFLO & ICMIBIO \\
\hline
\end{tabular}

